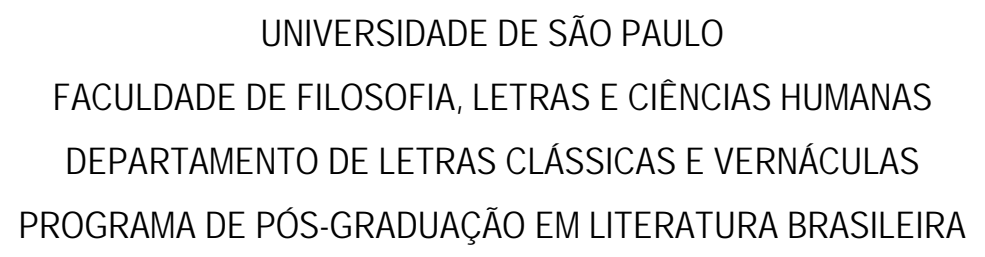

Giuliana Martins Simões

\title{
Veto ao Modernismo no Teatro Brasileiro
}

Tese apresentada ao Programa de Pós-Graduação em Literatura Brasileira, do Departamento de Letras Clássicas e Vernáculas da Faculdade de Filosofia, Letras e Ciências Humanas da Universidade de São Paulo, para obtenção do título de Doutora em Letras.

Orientação: Prof. Dr. João Roberto Faria

São Paulo

2009 
BANCA EXAMINADORA:

Prof(a) Doutor(a)

Prof(a) Doutor(a)

Prof(a) Doutor(a)

Prof(a) Dr(a)

Prof(a) Dr(a) 
À memória de minha mãe, Marita Martins. 


\section{AGRADECIMENTOS.}

Gostaria de agradecer, especialmente, ao meu orientador João Roberto Faria, pela confiança, desde o início, quando nem tudo parecia simples.

Aos professores Luiz Fernando Ramos e Berenice Raulino pelas sugestões e críticas no exame de qualificação.

Aos companheiros de trabalho do INERTE, Marcelo, Ana, Luciana e Thaís, pelas conversas e descobertas.

À Diana Signorelli, amiga nova e de apoio fundamental no princípio de tudo.

À Nora Vicente, amiga de sempre.

À Stella, Fernando Xavier, Daniel e Mariana, família divertida e adorável que me ajudou a dar risada nos momentos difíceis.

Aos meus irmãos, Nando e Dany e ao meu pai, queridos e sempre atentos ao meu caminho. Ao Flávio, meu melhor leitor.

À minha pequena Alice, que com seu sorriso deixou tudo mais fácil.

À Fundação Biblioteca Nacional, pela digitalização dos periódicos consultados, pela gentileza e facilidade com que me atendeu.

E à FAPESP - Fundação de Amparo à Pesquisa do Estado de São Paulo, pela bolsa concedida. 


\section{RESUMO}

A tese apresenta uma investigação acerca da história do teatro brasileiro, nas primeiras décadas do século XX, tendo-se em mente a maneira contrariada com que foram recepcionadas as experiências modernas sonhadas por uma geração de autores, tais como Renato Vianna, Flávio de Carvalho e Oswald de Andrade. Através dos estudos da estética da recepção, especialmente os textos desenvolvidos por Hans Robert Jauss, que dão ênfase ao aspecto histórico da recepção artística, a pesquisa busca compreender como esses autores respondiam aos desafios e questões pertinentes ao horizonte de expectativa de seu tempo. A recusa, como marca de recepção desses experimentos artísticos, não desqualifica a presença da renovação moderna na atividade teatral, ao contrário, os empecilhos encontrados pelos artistas para o desenvolvimento pleno de suas investigações cênicas - a falta de compreensão dos críticos para a análise de encenações modernas, as avaliações feitas a partir de critérios retrógrados, o mal estar provocado entre artistas e produtores, assim como os órgãos especializados em controle e censura que acompanhavam as atividades artísticas - explicitam a efetividade dessas experiências artísticas, e atestam o enfrentamento travado com regras e normas estabelecidas, que constituíam o horizonte estético do período.

\section{Palavras-chave:}

Teatro brasileiro; modernismo; estética da recepção; Oswald de Andrade; Flávio de Carvalho.

\section{Email:}

giulianasimoes@hotmail.com 


\begin{abstract}
This thesis examines the history of the Brazilian theater, during the first decades of the twentieth century, taking into account the unwilling reception of the modern experiences dreamt by authors such as Renato Vianna, Flávio de Carvalho e Oswald de Andrade. Through the studies of aesthetic of reception, especially those developed by Hans Robert Jauss, which emphasizes the historical aspect of the artistic reception, this research is an attempt to understand the way these authors responded to the challenges and issues related to the horizons of expectation of their time. The refusal, as a reception feature of those artistic experiments, do not depreciate the renovation of the theatrical activity, on the contrary, the hindrances met by those artists for a full development of their theatrical investigations - the lack of understanding from the critics for the analysis of modern performances, the assessments done from retrograde criteria, the malaise evoked between artists and producers, as well as the state agencies specialized on control and censorship that pursued artistic experiments - express the effectiveness of those artistic experiments, and testify the confrontation with the established rules and norms, which were the aesthetic horizon of that time.
\end{abstract}




\section{SUMÁRIO}

Introdução

.10

Capítulo 1 - O VETO COMO CONCRETIZAÇÃO.

Circunstâncias estéticas e históricas.

Mudança de horizonte e caráter artístico.

A experiência estética.

O artista e a emancipação do público.

Modernidade nas fachadas.

Fundamentos da crítica teatral.

A presença de Antoine no Brasil.

Repúdio ao vedetismo.

Regras personalistas e facilitação do diálogo com o espectador.

Alcântara Machado: uma outra crítica.

O moderno nas entrelinhas.

Capítulo 2 - VIGÊNCIA E EXCEÇÃO NA CENA BRASILEIRA.

O princípio dramático adotado pelas comédias.

Engrenagem dramática imperfeita nas comédias de Martins Pena.

Flores de sombra e Onde canta o sabiá.

Transmissão, formação e legitimação de normas sociais através da cena.

A flor dos maridos.

Capítulo 3 - BENJAMIN LIMA E RENATO VIANNA: RUÍDOS E RUMORES NA RECEPÇÃO. .100

Brechas para ponderações. 
Premiação negada.

As propostas de Renato Vianna.

Trabalho coletivo.

O texto como desdobramento de outras obras.

A encenação.

O atendimento ou não ao gosto do espectador.

Capítulo 4 - A EXPERIÊNCIA MODERNA EM FLÁVIO DE CARVALHO. 136

Os manifestos arquitetônicos

Os enfrentamentos da arte moderna.

O Teatro da Experiência.

O bailado do deus morto.

Diálogos e referências.

Embate estético.

Capítulo 5 - OSWALD DE ANDRADE: A INVENÇÂO DO ESPECTADOR. 169

Devorando as convenções.

Vozes dissonantes.

Evocação e destruição.

A recepção na mira de Oswald de Andrade.

Considerações finais .202

Bibliografia. .210 
Articular historicamente o passado não significa conhecê-lo "como ele de fato foi". Significa apropriar-se de uma reminiscência, tal como ela relampeja no momento de um perigo.

Walter Benjamim. 


\section{Introdução}

A história do teatro brasileiro no início do século XX nos dá indícios de uma dicotomia marcante: por um lado havia uma insatisfação com os rumos das artes cênicas proclamada pelos críticos e jornalistas da época - e para isto importa observar que "os principais textos teóricos e críticos versavam sobre a decadência da arte dramática no Brasil”"1 -, por outro havia uma recepção totalmente contrária às experiências modernas que já se anunciavam nesse período. O anseio pela renovação dos palcos ocupava e criava expectativas de realizações nos críticos da época, ao mesmo tempo em que estes, geralmente, não reconheciam, ou relegavam a segundo plano, qualquer tentativa de transformação ou de ousadia no panorama teatral.

A afirmação muitas vezes proferida por historiadores de nosso teatro sobre a efetivação do modernismo somente ter se dado na década de 1940, confirma a contrariedade com que estas investigações cênicas modernizadoras foram recebidas, mesmo em décadas posteriores, e a quase anulação sofrida justamente pela falta de compreensão que essas experiências obtiveram em seu tempo.

Duas correntes divergentes podem ser percebidas em nossos historiadores quanto à instauração do modernismo no teatro brasileiro, uma que opta por reconhecer o advento do moderno teatro entre nós somente nas produções efetivadas nos idos de 1940, recusando as concretizações realizadas em décadas anteriores como indicadoras da modernização de nossos palcos. Dentre esses historiadores, não há consenso, contudo, na fixação das balizas que definem a instauração do modernismo. Magaldi (1997) defende a encenação de Vestido de Noiva, em 1943, como marco dessa efetivação, enquanto Prado (2002) e Rabetti (1989) "localizam no TBC, em 1949, o efetivo empreendimento modernizante em relação às nossas práticas de palco”2, já Brandão (2002) entende que essa modernização só se realiza

\footnotetext{
${ }^{1}$ João Roberto Faria, Idéias teatrais. São Paulo, Perspectiva/Fapesp, 2001, p. 150.

${ }^{2}$ Edélcio Mostaço, Moderno (Teatro) - verbete. In: Dicionário do teatro brasileiro: temas, formas $e$ conceitos. J Guinsburg; João Roberto Faria; Mariângela Alves Lima (orgs.) São Paulo, Perspectiva, 2006, p. 186.
} 
com “a atuação do Teatro Popular de Arte, de Sandro Polloni e Maria Della Costa, em 1948”. 3 Há ainda outra corrente de historiadores que reconhece as experiências cênicas e renovações dramatúrgicas das primeiras décadas do século $\mathrm{XX}$, mas as vêem como mera sedimentação de terreno, de preparação para uma efetivação que era parcialmente instaurada, e que se dava aos poucos, estabelecendo-se de fato somente mais tarde, nos idos de 1940 (Dória, 1975).

Os historiadores concordam, assim, em um ponto: as experimentações teatrais efetivadas nos idos de 1920 e 1930 não podem ser estabelecidas como concretizações do moderno teatro brasileiro. A definição do marco do início dessa modernização coloca em pauta questão central para o nosso pensamento estético, que se refere à definição do próprio conceito de moderno na cena teatral. Questão esta que reverbera fundamentalmente no modo de compreender os variados acontecimentos artístico-teatrais ao longo de nossa história, e que estabelece tensão com a maneira de pensar os fatos do presente histórico, pois ressoa nas opções de análise tomadas em face das recentes experimentações teatrais em nosso país. Ou seja, os embates teóricos travados acerca da modernização de nossa cena não se referem somente a questões do passado, mas se tornam relevantes para a definição do teatro que queremos no presente e no futuro.

Como tal debate possui origem nas díspares pressuposições dos analistas, a eleição de uma ou outra corrente interpretativa, ou ainda sobre qual desses marcos eleger como baliza reconhecível, obriga a aceitar o moderno como um problema nos domínios da teoria teatral brasileira. ${ }^{4}$

As razões apontadas para que as realizações cênicas dos anos 1920 e 1930 não sejam consideradas como marco de instauração do teatro moderno no Brasil partem, por um lado, da negação de que as soluções artísticas propostas no período tenham efetivado a estética moderna em toda a sua plenitude. Ou seja, os autores que assim se posicionam compreendem, por motivações variadas, que aquelas realizações teatrais não se configuram como efetivamente modernas. Por outro lado, há teóricos que negam a concretização do teatro moderno nas primeiras décadas do século XX, pois defendem a idéia de que $o$ moderno no teatro só pode ser considerado como tal quando as propostas cênicas

\footnotetext{
${ }^{3}$ Idem, p. 186.

${ }^{4}$ Idem, p. 186.
} 
inovadoras caem de fato no gosto da crítica e, especialmente, do público, que passa a freqüentar com grande afluência os espetáculos teatrais. Os espetáculos podem, enfim, perfazer longas temporadas, o que está diretamente vinculado, segundo acreditam estes autores, com a "modernização" do aparato e do empreendimento teatral. Ou seja, o conceito de teatro moderno, nesse caso, se desloca do debate centrado no âmbito das questões propriamente estéticas para o âmbito do empreendimento. Somente quando os grupos se organizam como empresas, e quando o grande público freqüenta as salas é que se pode considerar a efetivação do conceito de “moderno” na realização teatral.

Nesse último caso, o conceito de arte moderna, e de teatro moderno, marcado por soluções artísticas que têm nas invenções cênicas e nas propostas de efetiva atuação feita ao espectador sua principal característica histórica, se confunde com a idéia de "modernização" do empreendimento teatral brasileiro. De modo que as soluções artísticas ficam submetidas a análises da perspectiva de sucesso empresarial como necessária efetivação do moderno, tomado aqui sob o parâmetro de uma pretensa "modernização" da sociedade brasileira, que geraria, enfim, condições para um teatro moderno.

Tentaremos demonstrar aqui, por um lado, que as experiências teatrais realizadas no período citado se efetivam como de fato modernas, que o modernismo no teatro se realiza em sua plenitude artística, e, por outro lado, que a concretização de uma obra de arte, ou de um movimento artístico, não está necessariamente relacionada com a boa aceitação desta pelo público e pela crítica teatral, e que a efetivação do moderno na arte não precisa estar atrelada à grande afluência de público. A defesa de um modernismo instaurado de fato só na década de 1940, desconsiderando as experiências anteriores, se dá não somente pela efetivação de encenações marcadamente modernas, mas também pela ampla repercussão que as produções teatrais, especialmente a encenação de Vestido de noiva, de Nélson Rodrigues, dirigida por Ziembinski, e as montagens do TBC (Teatro Brasileiro de Comédia), conquistaram em seu tempo.

Importa notar, contudo, que tanto Renato Vianna, em 1922, quanto, e especialmente, Flávio de Carvalho, em 1933, já haviam efetivado encenações marcadamente modernas. Além do que, a impossibilidade de montagem de algumas peças dramatúrgicas no período destacado - ou pela censura política que proibiu suas produções; ou ainda porque não foram bem recebidas por empresários, que não viam nelas boas 
oportunidades de lucro, o que pode ser configurado como uma "censura econômica” a essas obras, já que seus autores não encontraram meios de encená-las -, ou a falta de público, e mesmo as péssimas críticas que acompanharam espetáculos teatrais que apresentavam propostas inovadoras, são fatos representativos dessa recepção. Essa foi a maneira com que foram recebidos os primeiros lances do movimento moderno no teatro brasileiro. $\mathrm{O}$ fato das realizações modernas serem assim recebidas, sem o reconhecimento do público e da crítica especializada, não indica a sua não concretização, e muito menos se torna um dado suficiente para caracterizar as experiências inovadoras como um pré-modernismo, ou uma preparação para um modernismo que estava por vir.

Estamos nos referindo especialmente às seguintes experiências teatrais: a encenação de A última encarnação de Fausto, realizada pelo grupo de Renato Vianna, que ficou somente três dias em cartaz; a montagem da peça de Benjamin Lima, O homem que marcha, que esteve em cartaz em São Paulo, em 1925, despertando a revolta dos espectadores por tratar o adultério de maneira totalmente diversa do que se costumava fazer na cena teatral brasileira; a proibição pela polícia de eventos com propostas cênicas desconhecidas, tal como ocorreu com o "Teatro da Experiência”, de Flávio de Carvalho, fechado pela polícia em 1933 após três dias de funcionamento; e, finalmente, a não montagem do texto dramático $O$ rei da vela, de Oswald de Andrade, escrito na década de 1930, que em sua estrutura se mostrava portador de noções modernas de encenação. Importa notar, no caso de Oswald de Andrade, que a recusa a que seu texto foi submetido no período em que foi escrito, não sendo levado ao palco, apesar do desejo do autor em fazê-lo, representa a primeira e importante concretização dessa obra.

Para analisarmos de que maneira essas experiências marcam o modernismo tal como se efetivou, ou pôde se efetivar, na relação entre teatro e sociedade no Brasil de então, não priorizaremos, portanto, a sua boa acolhida pela crítica, ou seu sucesso de bilheteria, mas sim em que medida constituíam-se em propostas estéticas dissonantes, marcadas por uma linguagem cênica renovadora, e como respondiam aos desafios e questões pertinentes aos horizontes de expectativas de seu tempo.

A recusa como marca da recepção desses experimentos artísticos não desqualifica a inserção de noções modernas na atividade teatral, mas, ao contrário, nos revela como a revolução paradigmática proclamada pelo modernismo se deparava, por um lado, com 
ambiente oportuno para a instauração de experiências genuinamente brasileiras, e, por outro, não encontrava espaço para amplo desenvolvimento em nossa sociedade. Pode-se imaginar o impacto das propostas modernas em uma sociedade marcada pela ambigüidade, que procurava estabelecer avanços, contanto que estes não ocasionassem mudanças reais, que buscava conjugar conceitos díspares como latifúndio e democratização, vanguarda e imobilidade social.

A repercussão negativa ou difusa obtida por experimentos de cunho moderno que já se faziam presentes nas primeiras décadas do século XX, aponta para o diálogo travado entre as obras e seus receptores. O desvendamento de aspectos fundamentais desse diálogo - tal como o veto a que essas investigações cênicas foram submetidas no período, e as razões desse veto - nos convida a retornarmos a essas obras com um novo olhar, uma nova perspectiva, na busca de compreendê-las enfocando tanto aspectos de sua produção quanto de sua recepção histórica.

O evento passado não pode ser compreendido independentemente de suas conseqüências, nem tampouco a obra de arte de sua repercussão. ${ }^{5}$

Os variados aspectos que marcam e concretizam a recepção de uma obra de arte em seu período histórico, nos apresentam dados relevantes e fundamentais para analisarmos as inovações e quebras de expectativas que essas obras propunham em dado momento. Assim, partindo do presente, nos voltamos para a dramaturgia e a encenação do período em busca dos dados históricos de sua recepção que nos aproximem da experiência viva efetivada pelos leitores e espectadores de seu tempo, sem que pareça que estamos diante de uma “coleção de fatos mortos”.

Os estudos voltados para a estética da recepção, tal como desenvolvidos por Hans Robert Jauss, nos permitem estruturar tal aproximação e análise histórica. A atenção ao âmbito da recepção apresenta a possibilidade de recuperar dados sobre uma experiência estética ocorrida no passado. Para essa investigação referente ao teatro brasileiro, que significa, mais especificamente, aproximar-se da natureza do diálogo experimentado entre obras consideradas inovadoras, pois possuidoras de perspectivas modernas, e seus

\footnotetext{
${ }^{5}$ Hans Robert Jauss, Pour une herméneutique littéraire. Paris, Gallimard, 1982, p. 26.
} 
receptores, surge como ponto fundamental a reconstrução do horizonte de expectativa dominante no início do século XX no teatro brasileiro.

O horizonte de expectativa de uma obra é o conjunto de expectativas do seu público, dada sua situação concreta, o lugar da peça dentro da tradição literária, o gosto da época, a natureza das questões cuja resposta o texto constitui. ${ }^{6}$

O horizonte de expectativa acompanha tanto a obra, visto que nenhuma obra aparece sem estar envolvida em um contexto histórico, quanto os seus receptores. O contraste entre os diversos horizontes delineados nos fornece dados sobre o efeito causado por determinada obra em determinado público. Ou seja, a distância entre a expectativa do público e a proposta estética da obra nos indica o quão desestruturante aquela experiência artística se apresentava, e pode, em nosso caso específico, apontar as dificuldades com que foi recebida em seu tempo.

Para a análise das peças citadas anteriormente, escritas e/ou encenadas entre 1920 e 1940, e que não obtiveram uma repercussão favorável, faremos uma análise comparativa entre o conjunto de expectativas do público da época e as principais características dos textos escolhidos, levando em conta a natureza das questões que os textos referidos apresentam, reconhecendo os principais traços, sejam dramatúrgicos ou de encenação, que os afastavam do comumente visto em outros espetáculos. Ou seja, buscaremos reconhecer como atividades artístico-teatrais inovadoras se concretizaram nesse período e identificar os horizontes de expectativas, relativos às obras e aos seus receptores, e as correspondências e negações destes nas peças selecionadas.

\footnotetext{
${ }^{6}$ Patrice Pavis, Dicionário de teatro. São Paulo, Perspectiva, 2001, p.152.
} 


\title{
Capítulo 1
}

\section{O Veto como Concretização.}

\begin{abstract}
A recusa da recepção [da obra Flores do mal, de Baudelaire] por parte da maioria dos leitores contemporâneos é a primeira concretização desta obra pioneira.
\end{abstract}

Hans Robert Jauss

\section{Circunstâncias estéticas e históricas.}

A perspectiva dialógica, inerente à leitura de uma obra de arte, possui implicações tanto estéticas quanto históricas. No contexto estético, surge como aspecto relevante o fato de que a compreensão de uma obra se realiza através do diálogo com outras obras previamente conhecidas, uma obra contribuindo para o entendimento e a fruição de outra. Neste sentido, o contexto estético nos permite situar uma obra em relação a outras produzidas no mesmo período, e nos fornece bases importantes para percebermos em que medida uma determinada produção rompe com as normas de seu tempo, ou simplesmente confirma os padrões artísticos em voga. O contexto histórico da leitura de uma obra é ressaltado através da continuidade de recepções, ou seja, as diversas recepções ocorridas ao longo da história para uma mesma obra enriquecem o sentido original, possibilitando que aspectos não percebidos na época de sua feitura brotem posteriormente. Assim, “o sentido da obra de arte não deve ser entendido mais como substância atemporal, e sim como totalidade que se constrói historicamente”. ${ }^{1}$

O reconhecimento da mutabilidade de sentido nos conduz às diversas possibilidades de concretização que possui uma obra de arte ao longo da história. A noção de concretização em Jauss aparece definida nos seguintes termos:

\footnotetext{
${ }^{1}$ Hans Robert Jauss, apud Regina Zilberman, Estética da recepção e história da literatura, São Paulo, ática, 1989, p.65.
} 
Designo por esta palavra o sentido a cada vez novo que tanto a estrutura da obra quanto a do objeto estético pode possuir quando as condições históricas e sociais de sua recepção se modificam. $^{2}$

A concretização de sentido de uma obra ocorre condicionada pelas mesmas circunstâncias dialógicas que acompanham a natureza da obra: marcada, por um lado, pelas circunstâncias históricas, denominadas como o âmbito da recepção, e, por outro, pelas circunstâncias estéticas, denominadas como o âmbito do efeito. O efeito parte da obra, os estímulos para o seu reconhecimento estão localizados no próprio texto, por isso mesmo a sua variação é mínima. Alguns detalhes da obra podem se mostrar diferenciados de um olhar para outro, de uma percepção à outra, mas, no geral, sendo a obra fixa, ela carrega a mesma proposta estética para os diversos leitores.

Já a recepção surge a partir do leitor e das condições históricas que ele carrega consigo, e, por isso mesmo, é totalmente variável. O patrimônio de cada receptor, alterável em suas vivências pessoais e códigos coletivos, condicionam esta autoria. Enquanto o efeito depende da estrutura da obra, a recepção está condicionada aos fatores subjetivos e ao contexto social e histórico do receptor. Na aproximação entre os dois âmbitos, o do efeito e da recepção, ocorre a concretização da obra.

Condicionada por aspectos inerentes ao âmbito da obra e ao do leitor, a concretização de um texto, portanto, nunca ocorre da mesma maneira. Ainda que se trate de um mesmo leitor e de um mesmo livro, os fatores subjetivos responsáveis pela recepção da obra se modificam e alteram as condições da nova leitura.

Também eu sinto necessidade de reler os livros que já li, mas a cada leitura me parece estar num livro novo. Será que continuo a mudar e ver coisas que antes não percebera em outra leitura? Ou será a leitura uma construção que ganha forma reunindo um número de variáveis e não consegue repetir-se duas vezes obedecendo à mesma configuração? ${ }^{3}$

\footnotetext{
${ }^{2}$ Hans Robert Jauss, Por une esthétique de la réception, Paris, Gallimard, 1978, p. 213.

${ }^{3}$ Italo Calvino, Se um viajante numa noite de inverno. São Paulo, Companhia das letras, 1999, p.258.
} 
A obra artística necessita da atualização do receptor, ela não existe por si só, ainda que ofereça aos leitores e espectadores diferentes, em épocas diversas, uma mesma proposta estética. A recepção é momento constitutivo da obra, é a partir do encontro com o receptor que a obra de arte se atualiza. “A obra é, antes, como uma partitura voltada para ressonância sempre renovada da leitura".

Quando a recepção de uma obra possui repercussão negativa ou se dá através da recusa, ou seja, quando as circunstâncias sociais e estéticas de um tempo histórico não aceitam determinada proposta artística, abre-se a possibilidade de uma análise pormenorizada do horizonte de expectativas daquele período. A contrariedade provocada por determinada obra em seu tempo não descaracteriza a sua concretização, mas permite reconstruir as normas estéticas e morais com as quais possivelmente aqueles artistas romperam.

\section{Mudança de horizonte e caráter artístico.}

Quando lemos um texto, ou assistimos a um espetáculo teatral, não deixamos de lado as outras peças que já conhecemos. Ao contrário, as obras previamente conhecidas tornam-se material de referência para o diálogo com aquela com que estamos nos deparando. Nenhum receptor experimenta o contato com uma obra sem levar consigo impressões anteriores. Além disso, a vida social está também repleta de referências importantes a que um leitor recorre no encontro com uma nova experiência artística. O patrimônio vivencial e cultural do indivíduo participa da compreensão da obra, contribui na decifração de signos com os quais o leitor se depara. Esta bagagem do receptor, sempre sujeita a novas configurações, constitui o seu horizonte de expectativa.

Outra característica que acompanha inevitavelmente o encontro com uma obra artística é o fato de que toda obra, necessariamente, pertence a um gênero, que significa que nenhuma obra aparece sem estar envolvida em um contexto artístico referencial. Ou seja, toda expressão estética surge rodeada de regras pré-existentes, que podem ser reafirmadas ou negadas, mas que continuam como modelo de referência. As regras previamente

\footnotetext{
${ }^{4}$ Hans Robert Jauss, A história da literatura como provocação à teoria literária. São Paulo, Ática, 1994, p.25.
} 
conhecidas auxiliam a compreensão e o posicionamento do receptor diante da obra. Isto significa que toda obra de arte supõe um horizonte de expectativas.

O horizonte de expectativas representa, por um lado, o momento do público, o estado da sociedade, seu conhecimento do gênero literário ou teatral, e, por outro, a relação de uma determinada obra com outras que lhe antecederam, a correspondência entre a obra e os principais traços de um determinado gênero.

Os passos para a reconstrução deste horizonte encontram-se, primeiramente, nos dados literários, isto é, no próprio texto. Os casos exemplares para esta forma de reconstrução são aqueles em que as próprias obras evocam propositadamente um horizonte expectativo marcadamente conhecido por seus leitores, para, depois, ir desmontando-o gradativamente. Como exemplo, se pode citar o Dom Quixote, de Cervantes, romance efetivamente renovador à época de seu aparecimento, na medida em que é apresentado inicialmente enquanto romance de cavalaria para, em seguida, quebrar a expectativa do leitor propondo-lhe uma atitude receptiva renovada.

O caso ideal para a objetivação de tais sistemas histórico-literários de referência é o daquelas obras que, primeiramente, graças a uma convenção do gênero, do estilo ou da forma, evocam propositadamente um marcado horizonte de expectativas em seus leitores para, depois, destruí-lo passo a passo - procedimento que não pode servir apenas a um propósito crítico, mas produzir ele próprio efeitos poéticos. Assim é que Cervantes faz com que, da leitura do Dom Quixote, resulte o horizonte de expectativa dos antigos e tão populares romances de cavalaria, romances estes que a aventura desse último cavaleiro parodia, então, profundamente. ${ }^{5}$

Além desta obra de Cervantes, Jauss exemplifica a possibilidade de reconstrução do horizonte expectativo em Jacques, o fatalista, de Diderot. Através das perguntas fictícias feitas pelo leitor ao narrador logo no início do texto, o autor evoca assumidamente o horizonte de expectativa dos "romances de viagem", que estavam em voga naquele momento, para aos poucos ir se distanciando do modelo anunciado. O mesmo procedimento pode ser observado em Oswald de Andrade quando, em sua peça $O$ rei da vela apresenta discursos típicos da "peça de tese”, gênero cultivado no teatro brasileiro do

\footnotetext{
${ }^{5}$ Hans Robert Jauss, obra citada, 1994, p.28.
} 
final do século XIX, para, na seqüência da obra, desfazer qualquer semelhança esta forma dramática.

Em seguida, a objetivação deste horizonte torna-se possível com a análise de fatores externos, históricos e estéticos, que envolvem o receptor e por isso mesmo participam da constituição de sentido da obra.

A nova obra é observada em contraste com dados e situações vivenciais do receptor, ou seja, a experiência da realidade do leitor, da sua cotidianidade, servirá também de elemento para a constituição deste horizonte. Em suma, nenhuma obra é totalmente nova, ou melhor, o novo surge sempre em diálogo com o já existente, todo novo texto será percebido tanto através das diversas imagens e idéias criadas por textos anteriores, quanto por aspectos da vida social do leitor.

Um receptor, ao se deparar com uma obra de arte, possui informações prévias que possibilitam o seu diálogo com esta obra, fazendo com que aquela experiência estética lhe pareça legível. Além disso, ele é capaz de perceber em que momentos aquela obra se diferencia das outras obras que já conhece, e que fazem parte do momento histórico em que ele vive. Se um romance apresenta uma inovação marcante em sua forma de narrar, o leitor acostumado com a forma estabelecida imediatamente percebe e estranha.

As inovações propostas por artistas teatrais brasileiros no início do século $\mathrm{XX}$ podem ser consideradas como estranhas aos olhos do público de seu tempo. A apresentação de A última encarnação de Fausto, por Renato Vianna, em 1922, representava uma nova forma de construir um espetáculo e, portanto, de narrar uma história. A estranheza do público apareceu de imediato. É possível notar, através das críticas do período - que detalharemos no próximo capítulo -, como as inovações cênicas apresentadas nesta montagem deixaram o público desconcertado. A colocação do protagonista e da cena principal fora do centro do palco, assim como o posicionamento do coadjuvante no centro da cena, lugar pertencente, por convenção, ao primeiro ator da companhia, por exemplo, significavam uma quebra dos códigos vigentes na cena teatral do período, uma desordem aos olhos do público. Vianna se valia de recursos de encenação inéditos na prática teatral daquele momento, rompendo as expectativas de leitura do espetáculo e, ao mesmo tempo, convidando o espectador para uma leitura modificada da cena. 
Sobre os limites entre o horizonte de expectativa inicial, o já conhecido, e a obra nova, ou melhor, sobre a distância que separa um e outro, Jauss afirma que justamente esta medida revelará as características fundamentais de determinada obra.

A distância entre o horizonte de expectativa e a obra, entre o já conhecido da experiência estética anterior e a 'mudança de horizonte' exigida pela acolhida à nova obra, determina, do ponto de vista da estética da recepção, o caráter artístico de uma obra literária. ${ }^{6}$

Reconstruído este horizonte, estaremos próximos da formulação de questões às quais aqueles textos constituem resposta, estaremos nos aproximando da sociedade que recepcionou e, portanto, participou da produção de determinado movimento artístico.

Quanto mais próxima de uma expectativa geral, quanto mais ligada ao já experimentado, mais distante se estará da possibilidade de causar no público receptor um esforço de compreensão, de provocar uma guinada em suas convicções e em seus horizontes. A quebra do horizonte de expectativa se dá justamente quando as expectativas conhecidas são negadas, quando somos surpreendidos, quando um modelo conhecido aparece destruído. Uma espécie de desmantelamento das convicções antigas surge toda vez que uma obra supera o horizonte conhecido, gerando assim um esforço de compreensão para o receptor.

Outro exemplo de esforço proposto pela produção teatral brasileira do período pode ser observado no que exigiu Oswald de Andrade dos seus leitores, quando, em $O$ rei da vela, o escritor deu ao casal protagonista os nomes de Abelardo e Heloisa, propondo uma alusão clara com o casal trágico do século XII, para em seguida desfazer a semelhança, fazendo com que esta analogia frustrada estivesse carregada com um potencial de sentidos, a serem concebidos pelo receptor.

Oswald, conhecendo o procedimento vanguardista de Alfred Jarry, que em Ubu Rei, obra seminal do experimentalismo contemporâneo lançada em 1896, fez a paródia de Macbeth e lady

\footnotetext{
${ }^{6}$ Idem, p.31.
} 
Macbeth, subtrai toda a paixão de Abelardo e Heloisa, proclamando que seu matrimonio é um negócio. ${ }^{7}$

Oswald desenvolveu o seu texto tendo em mente um diálogo intenso com os espectadores/leitores. Estes são convidados a desempenhar um ato produtivo em sua relação com a obra, colocando-se como sujeito ante o objeto apresentado; procedimento, ressalte-se, característico do drama moderno. Ao se afastar do usualmente aceito no teatro brasileiro, o dramaturgo negava o horizonte de expectativas de seu tempo e exigia dos receptores esforços interpretativos para a compreensão da cena. Somente através deste esforço o espectador contemporâneo conseguiria se relacionar com a obra.

Jauss, como apontado acima, compreende que o valor da obra decorre da percepção ou do grau de experiência estética que a mesma é capaz de suscitar, apontando para o fato de que a criação artística contraria a percepção usual do receptor e modifica o seu horizonte expectativo. A proximidade entre a obra e o horizonte já existente, entre o que esta propõe e o que já pertence ao senso comum, a aproxima, segundo o autor, da "arte culinária” ou ligeira.

A arte ligeira deixa-se caracterizar, segundo a estética da recepção, pelo fato de não exigir nenhuma mudança de horizonte, mas sim de simplesmente atender a expectativas que delineiam uma tendência dominante do gosto, na medida em que satisfaz a demanda pela reprodução do belo usual, confirma sentimentos familiares, sanciona as fantasias do desejo, torna palatáveis - na condição de "sensação" - as experiências não corriqueiras ou mesmo lança problemas morais, mas apenas para "solucioná-los” no sentido edificante, qual questões já previamente decididas. ${ }^{8}$

A arte, desta maneira, está relacionada ao prazer, ao conhecimento e também à possibilidade de quebra do código vigente de expectativas. A partir desta perspectiva pretendemos observar o projeto teatral moderno que se concretizava, através de experiências artísticas nem sempre bem sucedidas, nas primeiras décadas do século XX, tanto no Rio de Janeiro quanto em São Paulo.

\footnotetext{
${ }^{7}$ Sábato Magaldi, Teatro da ruptura: Oswald de Andrade. São Paulo, Global, 2004, p.8.

${ }^{8}$ Hans Robert Jauss, obra citada, 1994, p.32.
} 


\section{A experiência estética.}

A experiência estética, colocada em primeiro plano pelos estudiosos da recepção, é fruto do relacionamento do texto com o leitor. Para vislumbrarmos os elementos constitutivos desta experiência devemos nos concentrar na interação que surge entre produção e recepção de uma obra artística. Esta interação não se apresenta de forma estática, ao contrário, se constitui como espaço modificável pelo tempo e pelas sociedades, repleto de elementos variados e aspectos renováveis.

O elemento estético não se apresenta enquanto "uma essência de certos objetos, nem uma disposição estável do que se chamou a natureza humana”, e sim "um modo de relação dos homens com os objetos, cujas características variam segundo as culturas, os modos de produção e as classes sociais". ${ }^{9}$ A noção de historicidade que acompanha a definição de elemento estético define também a noção de experiência estética.

Ao longo dos tempos modernos a experiência estética ganhou novos atributos. Assim como a arte se liberou de uma tradição secular que a definia como "mimesis ao cosmos, à natureza ou à idéia" 10 , a experiência estética passou a significar para o artista e para o público uma atividade construtiva, criadora, como o exercício de uma "faculdade poética" ${ }^{11}$. O acontecimento estético vê-se, desde então, relacionado à possibilidade de emancipação do sujeito receptor. Esta emancipação produzida pela experiência estética moderna está centrada na liberação de percepções usuais, automatizadas, e na concepção de novos parâmetros para a análise do cotidiano, fomentando no leitor uma nova maneira de ver, sentir e pensar o mundo.

Segundo Jauss, esse processo emancipatório, de caráter comunicativo e libertador, pode se efetivar com maior ou menor intensidade. Na medida em que a obra contraria um código ou um "sistema de respostas" vigentes ela propicia a intensificação deste processo; quando confirma o já conhecido este processo aparece atenuado. Ao se desvencilhar de uma engrenagem opressora, ao sugerir uma nova apropriação da vida social, a obra de arte,

\footnotetext{
${ }^{9}$ Nestor Garcia Canclini, A socialização da arte. São Paulo, Cultrix, 1984, p.11.

${ }^{10}$ Hans Robert Jauss, obra citada, 1978, p.138.

${ }^{11}$ Idem, p.138.
} 
apreciada e compreendida pelo seu destinatário, convida-o também a experimentar este mesmo universo de liberdade e inventividade.

Caracterizando a experiência estética, Jauss explica porque é lícito pensá-la como propiciadora de emancipação do sujeito: em primeiro lugar, liberta o ser humano dos constrangimentos e da rotina cotidiana; estabelece uma distância entre ele e a realidade convertida em espetáculo; pode preceder a experiência, implicando então a incorporação de novas normas, fundamentais para a atuação e compreensão da vida prática; e, enfim, é concomitantemente antecipação utópica, quando projeta vivências futuras, e reconhecimento retrospectivo, ao preservar o passado e permitir a redescoberta de acontecimentos enterrados. ${ }^{12}$

A experiência estética, defendida por Jauss como procedimento capaz de abolir hábitos alienantes de percepção e propiciadora de emancipação, aparece em seus ensaios composta por três atividades simultâneas e complementares: a poiesis, a aisthesis $e$ a katharsis. O primeiro plano, o da poiesis, pode ser compreendido como a atitude produtiva do receptor ao se deparar com o objeto estético, a manifestação deste na autoria da obra. Jauss inspira-se na caracterização de Hegel sobre a arte segundo a qual "o indivíduo, pela criação artística, pode satisfazer a sua necessidade geral de sentir-se em casa no mundo, ao retirar do mundo exterior a sua dura estranheza e convertê-la em sua própria obra”. ${ }^{13}$. Esta “necessidade geral do indivíduo" faz com que diante de uma obra de arte, o fruidor se coloque como co-produtor e faça do objeto artístico sua obra. Retomando a história da noção de poiesis no pensamento ocidental, Jauss aponta que ela se tornou praticamente uma exigência nas criações artísticas desde o início do século XX, já que, a partir de então, a participação do receptor no processo de produção da obra de arte se torna cada vez mais necessária. A poiesis aparece, portanto, como "faculdade poética” conferida ao receptor, e representa aspecto fundamental da experiência estética.

O segundo plano, o da aisthesis, representa o conhecimento sensível em detrimento do conhecimento conceitual. Relaciona-se ao efeito provocado pela obra de arte no receptor, a mobilização causada pelo contato com a obra, a qual pode se traduzir em

\footnotetext{
${ }^{12}$ Regina Zilberman, obra citada, p.54.

${ }^{13}$ Hans Robert Jauss, obra citada, 1979, p.80.
} 
capacidade concedida ao receptor de renovação do seu ponto de vista, de sua visão do mundo circundante e, a partir desta perspectiva renovada, surge também a possibilidade de mudança desta percepção. Jauss atribui a esta atividade a finalidade própria da arte de “descobrir novos modos de experiência na realidade mutável ou propor alternativas para ela” ${ }^{14} \mathrm{O}$ sentimento que surge relacionado a este plano da experiência estética é o prazer da “percepção reconhecedora” e do “reconhecimento perceptivo”. Assim como a poiesis, a aisthesis também encontra orientações na arte moderna:

Jauss concorda em que somente criações altamente experimentais, como as do século XX, podem acordar o sujeito de sua alienação numa sociedade reificada. ${ }^{15}$

Por fim, a katharsis, defendida pelo autor como a atividade mais importante, pois mobilizadora em sua essência, representa a concretização do processo de identificação que, por sua vez, possibilita a compreensão da experiência sensível como uma informação acerca do mundo.

Designa-se por katharsis aquele prazer dos afetos provocados pelo discurso ou pela poesia, capaz de conduzir o ouvinte e o espectador tanto à transformação de suas convicções, quanto à liberação de sua psique. ${ }^{16}$

O espectador não somente sente prazer, mas também é convidado a agir de acordo com a nova percepção adquirida. A katharsis é o momento em que a experiência subjetiva, experimentada pelo receptor no encontro com a obra, se efetiva e se deixa transformar em fator comunicativo ou em experiência intersubjetiva. Este plano da fruição estética mostrase capaz de libertar o espectador dos interesses puramente práticos e dos compromissos cotidianos, concedendo-lhe uma visão mais clara dos acontecimentos e estimulando-o a julgá-los de maneira renovada.

\footnotetext{
${ }^{14}$ Regina Zilberman, obra citada, p.56.

${ }^{15}$ Idem, p.56.

${ }^{16}$ Hans Robert Jauss, obra citada, 1979, p.80.
} 
A experiência estética, ressalta Jauss, somente conserva a sua natureza quando o caráter de prazer aparece presente em suas atividades, que podem, portanto, ser definidas como diferentes momentos do prazer estético: primeiramente, a consciência produtora (poiesis); posteriormente, a consciência receptora (aisthesis); e, por fim, a experiência estética comunicativa (katharsis), ou seja, a transformação da experiência subjetiva em experiência comunicável.

Torna-se importante ressaltar que a concepção destes três planos da experiência estética, tal como formulada pelo citado teórico da recepção, está intrinsecamente relacionada com as propostas artísticas modernas. Se o advento do teatro moderno pode ser observado pelo "surgimento" do espectador, ou melhor, pela assunção da necessária participação do espectador no evento, a poiesis, a aisthesis e a katharsis constituem-se em planos em que se pode observar e compreender a importância e a produtividade características ao papel conferido ao espectador teatral na modernidade.

O prazer estético, apontado pelo autor, se difere do prazer simples, e suas diferenças estão relacionadas ao tipo de processo desencadeado por cada um deles no receptor. A entrega sensitiva e elementar do eu a um objeto relaciona-se ao prazer simples. Este se dá sem a elaboração de relações com o mundo à sua volta, um prazer que se efetiva no isolamento, apresentando-se como auto-suficiente. Já o prazer estético elimina o isolamento próprio do prazer simples, realiza o afastamento entre o sujeito e o objeto contemplado, a ponto de estabelecer relações entre a experiência proporcionada pelo objeto do prazer e a realidade circundante. Enquanto o prazer simples se satisfaz com o tempo que dura o contato com o objeto, o prazer estético exige um tempo adicional, tempo para elaboração, para uma tomada de posição diante da experiência vivida. A possibilidade de se afastar do objeto, de excluir a sua existência e de se posicionar diante dele, determina a transformação do objeto em objeto estético.

Em Jauss, vemos a afirmação da importância e validade da experiência estética, surgindo inclusive como experiência cognitiva, que proporciona aprendizado. A arte encontra-se, assim, relacionada ao prazer, ao conhecimento e também à emancipação, caracterizada, sobretudo, pela quebra de expectativas e pela concepção de um novo horizonte de respostas e parâmetros para análise e discussão da vida social. 


\section{O artista e a emancipação do público.}

O diálogo entre artista e público, tal como compreendido pela estética da recepção, revela como as obras podem se sujeitar às expectativas do seu tempo ou como podem alterá-las, projetando novos comportamentos e posicionamentos artísticos e vivenciais. O confronto entre as diversas propostas permite posicionar o artista diante de sua época, esclarecendo suas opções, da mais submissa à mais revolucionária.

Como exemplo de quebra de expectativas e de rompimento do cânone estético de um período, Jauss sugere o romance de Gustave Flaubert, Madame Bovary. Publicado na França, em 1857, o romance sofreu processo judicial, sendo acusado de violação da moral pública, e somente com o passar do tempo teve o seu valor literário reconhecido. Em contrapartida, como exemplo de obra confirmadora de códigos estabelecidos, o teórico da recepção indica o romance Fanny, de Feydeau, que, escrito no mesmo período e tratando do mesmo tema, o adultério, obteve impressionante êxito na época de seu aparecimento; em um ano foram feitas 13 edições da obra. O tema dos romances é o mesmo, a forma, entretanto, apresenta-se bastante diversa. Em Flaubert, a quebra dos padrões literários da época, lhe valeu a recusa do público e da crítica, além de um processo judicial; em Feydeau, a permanência dos horizontes expectativos, a reafirmação do modelo referencial conhecido, lhe possibilitou um retumbante sucesso editorial.

Flaubert construiu uma narrativa impessoal, na qual Ema Bovary encara o adultério como "uma forma sublime de dandysme”. ${ }^{17}$ Esta maneira impassível encontrada pelo autor para narrar a sua história desafia o modelo literário conhecido, tornando o seu romance difícil para os leitores do seu tempo. O drama construído por Feydeau, por outro lado, aparece em tom confessional, comumente utilizado, e por isso mesmo apresenta-se num tom facilmente digerível para os leitores contemporâneos. A fim de abordar o adultério sob um novo ponto de vista, para assimilar as sutilezas deste tema, Flaubert estruturou um discurso artístico com formatação renovada, atingindo desta maneira não somente um efeito formal, mas também um efeito poético.

\footnotetext{
${ }^{17}$ Hans Robert Jauss, obra citada, 1994, p.33.
} 
O processo judicial movido contra Flaubert - o que, ressalte-se, está relacionado com a perspectiva emancipatória proposta ao leitor do período - se dá sob a alegação de que o autor, em sua narrativa impessoal, não proferiu um julgamento sobre o adultério ou mesmo concebeu uma personagem que repudiasse a atitude de Emma Bovary, deixando claro para os leitores a sua recusa ante a atitude adúltera da protagonista. Assim, o autor propõe que o próprio leitor empreenda uma atitude crítica acerca do fato, com liberdade para efetivar um juízo próprio acerca da temática abordada.

Interessante notar, neste exemplo concebido por Jauss, o fato de que as trajetórias distintas dos romances só podem ser compreendidas a partir do efeito causado no público. Os leitores de romances assimilaram facilmente a forma adotada por Feydeau e o consagraram como obra-prima de seu tempo, obscurecendo inclusive a obra de Flaubert, que não agradou que a um pequeno círculo de conhecedores. Quando, porém, o romance de Flaubert foi, aos poucos, sendo descoberto pelos apreciadores de romance, tornou-se um sucesso mundial e os leitores formados por esta obra literária passaram a achar insuportáveis as características pertencentes ao estilo de Feydeau, renegando "seu estilo floreado, seus efeitos da moda, seus clichês lírico-cofessionais - fazendo amarelecer qual um best seller do passado as páginas de Fanny”.18

O fato ilustra de maneira clara a complexidade com que deve ser encarada a relação entre obra, autor e público. Não se pode supor que o fato de uma obra tornar-se um sucesso em um determinado período possa sustentar, como se faz em senso comum, a defesa de que aquela obra representa a principal imagem daquele público, ou que era aquele tipo de texto que o público ansiava, ou que aquele era o gosto do público e que, assim, não restava outra saída aos artistas que não fosse produzir algo naquele estilo. As opções diferenciadas, que a princípio desagradam o público, são capazes de transformar o horizonte de expectativa de um período e modificar o cânone estético do seu tempo. Segundo a estética da recepção, a compreensão relativa ao círculo formado por escritor obra e público possui premissa dialética, e uma produção artística, em suas inovações temáticas e formais, pode antecipar o advento de novas percepções estéticas.

\footnotetext{
${ }^{18}$ Idem, p.34.
} 
Há obras que, no momento de sua publicação, não podem ser relacionadas a nenhum público específico, mas rompem tão completamente o horizonte conhecido de expectativas literárias que seu público somente começa a formar-se aos poucos. ${ }^{19}$

Não é necessário que exista um público pronto para que uma obra inovadora seja acolhida e assim concretizada. A concretização de uma obra pode se dar antes mesmo da existência desse público específico. A obra é ela mesma propiciadora de novos preceitos estéticos, e formadora de um novo público, ou de uma nova percepção no público. A recepção da obra, quando se apresenta distante do comumente conhecido, “deixa-se objetivar historicamente no espectro das reações do público e do juízo da crítica - sucesso espontâneo, rejeição ou choque, casos isolados de aprovação, compreensão gradual ou tardia”. ${ }^{20}$

Justamente por ter sido alvo de escândalo público, a obra de Flaubert e seus numerosos registros de recepção, tais como as críticas favoráveis e contrárias de jornais e artigos do processo que a obra sofreu, permitem a reconstituição das normas estéticas e morais com as quais o autor rompeu definitivamente. Ou seja, reconhecer as quebras de convenções literárias inseridas em uma obra inovadora possibilita reconhecer também as normas vigentes da época.

Ao mesmo tempo em que aparecem obras revolucionárias, surgem também, como vimos, aquelas que buscam corresponder ao gosto do público e, por isso mesmo, apresentam-se sem contrariedades para os seus receptores, sem distanciar-se do já conhecido e, por isso, são mais facilmente aceitas. Acontece que obras com recepções iniciais negativas, tais como Madame Bovary, de Flaubert, e Spleen, de Baudelaire, são aquelas que se tornam responsáveis pela transformação do olhar do receptor e pela formação de um novo cânone estético. O esforço de compreensão exigido pelos autores, em suas proposições por vezes desconcertantes, sinaliza a possibilidade de uma experiência estética plena, capaz de liberar o sujeito receptor de hábitos alienantes de percepção, abrindo-o para novas possibilidades de compreensão acerca dos ditames da arte e das nuances da vida.

\footnotetext{
${ }^{19}$ Idem, p.33.

${ }^{20}$ Idem, p.31.
} 
As obras literárias que agradavam o público francês em meados do século XIX defendiam um tema de orientação burguesa e doméstica: a doçura do lar. As expectativas que envolviam este tipo de obra eram justamente aquelas contra as quais os dois autores, Flaubert e Baudelaire, se chocaram quando publicaram livros que contradiziam ou problematizavam essas imagens.

Através da análise proposta pelos estudos da recepção, do levantamento da repercussão da obra diante de diferentes momentos históricos, torna-se possível reconhecer se a obra tem cunho social, se está comprometida com o presente histórico e em que medida contradiz o dito. O modo como o artista dialoga com a realidade em seu trabalho nos fornece indícios de seu contato com a sociedade.

Para a estética da recepção, é irrelevante se a obra de arte, mesmo a mais programaticamente realista, reproduziu fielmente o universo circundante. Importa antes recuperar o modo como a realidade foi transferida para a ficção, pois a explicitação desse processo permite definir a resposta do artista às necessidades e solicitações de seu público. ${ }^{21}$

A superação das expectativas de um determinado público aumenta a possibilidade de interferência deste na obra. Assim, atender às solicitações do público significa, por mais paradoxal que possa parecer, contribuir para a falta de participação do mesmo enquanto produtor da obra.

Ora, se o valor estético da obra pode ser medido através da distância entre o horizonte estético proposto pela obra e o já conhecido, e quanto maior essa distância maior o seu valor estético, a possibilidade de efetivação de uma experiência artística valorosa se dá justamente quando as expectativas do público não são atendidas. A aceitação dos gostos mais fáceis do público confirma a idéia de uma arte que não intensifica a relação com os seus receptores, que os mantêm alheios à produção.

\section{Modernidade nas fachadas.}

A objetivação do horizonte de expectativa do teatro brasileiro, tal como destacamos anteriormente, define-se tanto a partir da análise das obras - que serão comentadas no capítulo seguinte - quanto de aspectos marcantes da recepção destas pelo público do seu

\footnotetext{
${ }^{21}$ Regina Zilberman, obra citada, p.100.
} 
tempo. Para vislumbrarmos os elementos constituintes desta recepção torna-se fundamental reconhecermos o ambiente histórico em que estas obras surgiram. Nesse sentido, em busca dos contornos deste ambiente, destacaremos, primeiramente, alguns dados sobre a sociedade brasileira, enfocando fatos que podem ser relacionados com características marcantes da produção teatral do período, e, posteriormente, aspectos constituintes dos fundamentos da crítica teatral de então, que se colocava como mediadora da relação entre produção e recepção artística.

A nova obra é recebida e julgada tanto em seu contraste com o pano de fundo oferecido por outras formas artísticas, quanto contra o pano de fundo da experiência cotidiana da vida. ${ }^{22}$

Durante os primeiros anos da República, a cidade do Rio de Janeiro, então capital do país, passou por diversas transformações de natureza econômica, social, política e cultural, que estavam em processo desde o final do século passado, mas que se precipitaram com a mudança de regime político. Estas transformações, realizadas de maneira desordenada e turbulenta, deixaram a cidade com um ritmo frenético. Neste ambiente, parte da população tornou-se consumidora voraz de tudo que chegava de países europeus, uma verdadeira febre de consumo tomou conta da cidade.

O advento da República proclama sonoramente a vitória do cosmopolitismo no Rio de Janeiro. O importante, na área central da cidade, era estar em dia com os menores detalhes do cotidiano do velho Mundo. E os navios europeus, principalmente franceses, não traziam apenas os figurinos, o mobiliário e as roupas, mas também as notícias sobre as peças e livros mais em voga, as escolas filosóficas predominantes, o comportamento, o lazer, as estéticas e até as doenças, tudo enfim que fosse consumível por uma sociedade altamente urbanizada e sedenta de modelos de prestígio. $^{23}$

O modo de vida europeu passou a encantar a tal ponto a sociedade carioca que os beneficiários, aqueles que desfrutavam dessas novidades, se organizaram para garantir a sua manutenção, exigir a sua extensão e impedir que houvesse retrocessos. Existia nesse período uma propaganda intensiva em jornais e revistas sobre os prazeres desencadeados

\footnotetext{
${ }^{22}$ Hans Robert Jauss, obra citada, 1994, p.53.

${ }^{23}$ Nicolau Sevcenko, Literatura como missão: tensões sociais e criação cultural na Primeira República. São Paulo, Companhia das Letras, 2003, p.51.
} 
pelo consumo, pelo modo de vida elegante e, especialmente, pela adesão aos hábitos europeus de diversão. O jornalista Figueiredo Pimentel, na sua seção “O binóculo”, da Gazeta de Notícias, indicava algumas diversões que deveriam ser apreciadas pelos componentes da "alta sociedade carioca”. A Batalha das Flores no Campo de Santana ${ }^{24}$, o five-o'clock tea, os corsos de Botafogo e da Avenida Central, e o footing do Flamengo eram considerados diversões chics. Pimentel também ditava a moda masculina e feminina da cidade, tendo implantado expressões como “o Rio civiliza-se” e "smart”, que representava o tipo cosmopolita elegante.

Nessa tentativa desenfreada de assimilação do imaginário europeu, compreendido como sinônimo de civilização, surgia também a perseguição às festas e rituais populares. Foram proibidas as festas de malhação do Judas e do bumba meu boi. No Rio de Janeiro, a festa de São João era criticada pelos jornais, assim como as comemorações em homenagem a Nossa Senhora da Penha, em São Paulo. O jornalista João Luso, cronista do Jornal do Commércio e tradutor freqüente de peças francesas para o ator e empresário Leopoldo Fróes, manifestava em sua coluna preocupação quanto ao culto do candomblé que parecia se espalhar pela cidade:

Veja amigo o que diz esse jornal: o último [candomblé] foi a polícia encontrá-lo na Rua do Lavradio, lá embaixo, junto a Praça Tiradentes! É extraordinário, mais alguns dias teremos um candomblé na Avenida! ${ }^{25}$

O carnaval recomendado entusiasticamente pelos meios de comunicação era o da versão européia, habitado por personagens estrangeiros. As fantasias de pierrô e colombina e o comportamento comedido eram apreciados, enquanto as fantasias de índios, os batuques e os cordões repudiados. "O carnaval expressava em parte uma cultura afro-brasileira da qual a elite afinada com os padrões europeus se envergonhava”. ${ }^{26}$ As revistas, desde o início do século, passaram a noticiar o carnaval utilizando-se de imagens identificadas com a cultura européia. A capa da revista A Semana, de janeiro de 1922, apresentava a figura de um arlequim, um pierrô e uma colombina elegantemente vestidos e dignamente

\footnotetext{
${ }^{24}$ A Batalha das Flores consistia em reuniões, realizadas com patrocínio oficial, para os membros da alta sociedade carioca, que, no Campo de Santana, acompanhavam competições de jangadas com alegorias florais e desfrutavam da cozinha francesa ao som de uma orquestra (Jeffrey Needel, 1993, p. 291).

${ }^{25}$ João Luso, apud Nicolau Sevcenko, obra citada, 2003, p.321.

${ }^{26}$ Jeffrey Needell, Belle époque tropical. São Paulo, Companhia das Letras, 1993, p.71.
} 
comportados numa festa de carnaval. Na revista Careta, de janeiro 1909, aparecia um pierrô surrando um índio, numa referência à proibição, ocorrida nesse mesmo ano por parte da polícia, ao uso de fantasias de índio, sob a alegação de que os adereços esconderiam armas.

A necessidade de seguir as tendências atuais da moda européia, copiando desde o modo de se vestir - a sobrecasaca e a cartola alta, ambos pretos, eram trocados pelos trajes mais leves como os paletós de casimira clara e os chapéus de palha - até o modo de se divertir - as varandas e os salões coloniais, como espaço de lazer, eram trocados pelas avenidas, cafés e praças da cidade -, comandava as principais mudanças da sociedade.

O espaço urbano também era remodelado para abrigar esses habitantes europeizados. A cidade recebia reformas urbanísticas, porém isso não significava melhores condições de vida para a população, ou pelo menos para uma grande parte dela. Ao contrário, ao mesmo tempo em que os velhos casarões eram destruídos e as ruelas coloniais eram substituídas por grandes avenidas, facilitando a circulação de automóveis, no mesmo período que a capital do país ganhava aspecto de cidade européia, com praças povoadas de pardais importados da França, ocorria o surgimento das favelas no Rio de Janeiro.

A avenida central, como a belle époque que simbolizava, pulsava entre dois pólos; a realidade colonial e o dinamismo da metrópole em constante contraponto, uma tensão básica para a explicação e a experiência do mundo aqui em discussão. ${ }^{27}$

A parte central da capital fluminense, símbolo da paisagem afrancesada deste período, era a única que merecia cuidados, os arredores permaneciam abandonados, assim como a população que ali residia. Aliás, tornar invisíveis as dificuldades que acompanhavam parte da população e da cidade parecia fazer parte da fantasia cosmopolita burguesa. "Pois, nas mudanças da belle époque, a elite celebrava não só o que era feito, mas também o que era desfeito". 28

Os casarões antigos do centro da cidade que abrigavam a maior parte da população modesta do Rio foram quase todos destruídos. A febre demolitória, iniciada em 1892, que chegou ao auge em 1904, com a política da Regeneração, expulsou toda esta população

\footnotetext{
${ }^{27}$ Idem, p.67.

${ }^{28}$ Idem, p.67.
} 
para as zonas mais estreitas e desamparadas da cidade. As favelas e os bairros pobres do subúrbio representavam o outro lado da moeda dessa modernidade ambígua que deveria permanecer esquecido.

Há casas, casinhas, casebres, barracões, choças por toda a parte onde se possa fincar quatro estacas de pau e uni-las por paredes duvidosas. Todo o material para essas construções serve: são latas de fósforos distendidas, telhas velhas, folhas de zinco, e, para as nervuras das paredes de taipa, o bambu, que não é barato. Há verdadeiros aldeamentos dessas barracas, nas covas dos morros, que as árvores e os bambuais escondem aos olhos dos transeuntes. Nelas há quase sempre uma bica para todos os habitantes e nenhuma espécie de esgoto. Toda essa população pobríssima vive sob a ameaça constante da varíola e, quando ela dá para aquelas bandas, é um verdadeiro flagelo. ${ }^{29}$

Surgiram também, nesse período, inúmeras ocupações alternativas que apontavam para a condição miserável de parte da população: os “cavaqueiros” eram aqueles que revolviam o lixo em busca de materiais vendáveis, os “apanha-rótulos e selistas” buscavam rótulos de artigos importados e selos de charutos finos para vender aos falsificadores, os "trapeiros" coletavam trapos, e os "caçadores de gatos" vendiam os animais aos restaurantes, que os revendiam como se fossem coelhos.

Deixando os arredores em ruínas e grande parte da população de lado, a preocupação da classe dirigente era conceder ares de progresso à República. E o conceito de progresso significava "alinhar-se com os padrões e o ritmo de desdobramento da economia européia”. ${ }^{30}$ Assim, o início do século XX no Brasil, tanto no Rio de Janeiro como em São Paulo, possui como característica fundamental a importação compulsiva do imaginário europeu. Acontece que, na maioria das vezes, “eram idéias mal absorvidas, ou absorvidas de modo parcial e seletivo, resultando em grande confusão ideológica”. ${ }^{11}$ A idéia de modernização da sociedade chegava, seguindo esta lógica, destinada a somente uma parte da cidade e da população, uma modernização de fachada que atendia a poucos. As cidades se transformavam de maneira rápida e contraditória, deixando grande parte da população desamparada. O retrato do centro da capital fluminense, com habitantes vestidos

\footnotetext{
${ }^{29}$ Lima Barreto, apud Nicolau Sevcenko, obra citada, 2003, p.76.

${ }^{30}$ Nicolau Sevcenko, obra citada, 2003, p.41.

31 José Murilo de Carvalho, Os bestializados. São Paulo, Companhia das letras, 2006, p.42.
} 
a caráter passeando tranqüilamente pelas ruas, nada tem a ver com a realidade da cidade como um todo.

A República brasileira assiste à remodelação e à modernização, quase compulsórias, das cidades e as incentiva, mas não permite que se formem cidadãos. ${ }^{32}$

A sociedade brasileira deste período se vê marcada pelo signo da ambigüidade, estabelecendo avanços, contanto que estes não ocasionem mudanças reais, buscando a modernização das ruas e promovendo, com a expulsão de parte da população para as zonas mais afastadas da cidade, o aumento da desigualdade social.

A necessidade de seguir as tendências européias, a negação de todo e qualquer elemento da cultura popular, a busca de características civilizadas para a sociedade dominante, que ainda usufruía vantagens herdadas do sistema colonial-escravista, a exclusividade de desfrute para as camadas aburguesadas da área central e a expulsão de parte numerosa da população da zona central para os arredores da cidade, foram os principais aspectos da metamorfose sofrida pela capital do país no período destacado.

As tendências européias se faziam presentes na sociedade brasileira na aparência, nos hábitos, no comportamento e na urbanização de algumas partes das cidades, as dificuldades crescentes da população, entretanto, não sofriam mudanças. O cerne das discussões do período, como a expansão dos direitos civis e políticos, a igualdade de direitos entre homens e mulheres, o direito ao voto para todos os cidadãos, não surgia com a mesma nitidez.

\section{Fundamentos da crítica teatral.}

Os registros das críticas teatrais do período revelam a mesma preocupação que ocupava a classe dirigente do novo governo: a de estar em dia, pelo menos na aparência, com o panorama europeu. Não é raro encontrarmos críticas comparando o modo de assistir espetáculos aqui e na capital francesa; até mesmo as claques, presentes nos teatros da capital, são comparadas com as claques francesas.

\footnotetext{
${ }^{32}$ Elias Tomé Saliba, A dimensão cômica da vida privada na República. In: Nicolau Sevcenko (org.). História da vida privada no Brasil vol. 3. São Paulo, Companhia das Letras, 1998, p.329.
} 
Entre nós a claque não está regimentada como em Paris. Os nossos clauqueurs são por via de regra os próprios comparsas, quando não tomam parte na representação: aplaudem a torto e a direito sem discernimento, sem critério, e muitas vezes são eles os únicos espectadores que batem palmas. Em Paris a claque faz parte integrante da mise-em-scène: o chefe assiste aos ensaios e concerta-se com o regisseur para a escolha das situações que devem ser aplaudidas. ${ }^{33}$

O comportamento correto dos "claqueurs" e dos espectadores comuns nas salas de espetáculo, a forma de ovacionar as estrelas sem cometer exageros, o repúdio às vaias e pateadas são algumas das regras divulgadas pelos cronistas da época, que buscavam mostrar uma forma "civilizada” de se relacionar com a cena teatral. Desde o século XIX, a crítica teatral brasileira usufruía do estilo da crônica para se aproximar do leitor “chegando-se por vezes a deixar de lado o registro ou o comentário dos espetáculos em cartaz em prol de uma espécie de diário pessoal”34 -, a difusão de regras de comportamento, aliada à proximidade despertada por este tipo de crítica, parecia ainda mais eficaz.

Essencialmente, entretanto, a crítica teatral não parecia disposta a participar de transformações substanciais, ou seja, na prática, não existia um projeto estético definido e os críticos se mostravam completamente presos às convenções antigas do gênero teatral, seja referente à relação da platéia com a cena, seja na avaliação dos trabalhos apresentados. Faltava à recepção crítica da época, composta muitas vezes por jornalistas que além de críticos eram também dramaturgos, formulação de questões que colaborassem com o aprimoramento da cena, faltava um projeto estético que também se mostrasse contagiado pelas mudanças políticas anunciadas pelos novos tempos. Mudanças que na sociedade brasileira apareciam de maneira difusa e contraditória.

A necessidade urgente de alterações no teatro brasileiro era, contudo, apontada com freqüência pela crítica. A desqualificação dos artistas, o pouco caso dos empresários teatrais para com os autores dramáticos nacionais e o mau gosto do público, que desmerecia as peças de qualidade literária, eram comentários recorrentes na imprensa da época. Este

\footnotetext{
${ }^{33}$ Artur Azevedo, apud Flora Sussekind, Papéis colados. Rio de Janeiro, Editora UFRJ, 1993, p.69.

${ }^{34}$ Flora Sussekind, obra citada, 1993, p.58.
} 
descontentamento por parte dos críticos em relação aos autores, artistas e público, pode ser observado através do artigo de Mário Nunes, crítico teatral do Jornal do Brasil de 1913 até 1935, escrito para a revista Don Quixote, e publicado no ano de 1938.

Muitos autores gozam em todo o Brasil de larga nomeada, sendo que quem escreve estas linhas bastante tem concorrido para isso, soprando abnegadamente, a tuba canora da vitória. Todos eles, porém, não vão além de um mérito relativo e os que mais se destacam não terá sido pelo valor intrínseco do que produziram, mas por chance, esperteza, impertinência, chantagem ou audácia.

O panorama é o mesmo quanto a atores e atrizes. (...) A incultura quanto a comezinhos preceitos da arte de representar é o caso geral, mas a culpa, aí, não é do indivíduo, mas do meio em que ele vive. Mesmo que quisesse estudar não teria onde.

O público com que conta o nosso teatro, com ele se nivela: adora a chanchada e quanto mais parva melhor. As peças que tenham um leve sentido literário o enfadam. Quer rir com sandices e deixar o teatro exclamando: gozado! $!^{35}$

O jornalista deixava claro, neste e em outros textos, que além de enxergar a pouca potência do teatro no Brasil, muitas vezes os elogios que conferia a alguns atores ou escritores do período eram muito mais com a finalidade de estímulo, com o ideal de protegê-los, do que propriamente reais. Se não faltava nitidez, por parte do crítico, quanto ao despreparo de artistas, autores e público para conceber um teatro de qualidade, faltava clareza para modificar tal situação. Os princípios da tarefa da crítica eram definidos da seguinte maneira:

Para que a crítica seja acatada e proclamada justa é necessário, conseguintemente, que seu critério de beleza seja o dominante, isto é, o que a maioria admite; se atenha às condições do meio; e esteja em harmonia com os princípios da moral aceita por quase todos. ${ }^{36}$

A preocupação em proclamar o dominante, o já conhecido como critério de beleza e de avaliação dos trabalhos artísticos, a negação de qualquer tipo de tentativa desafiadora das regras vigentes era o tom mais freqüente dos comentários feitos pelos críticos brasileiros. "A idéia de adequação parece ser um dos fundamentos da crítica do período”. 37

\footnotetext{
${ }^{35}$ Mário Nunes, 40 anos de teatro, 3 volumes, Rio de Janeiro, SNT, s.d, p.16.

${ }^{36}$ Idem, p.16.

${ }^{37}$ Flora Sussekind, obra citada, 1993, p.63.
} 
As críticas de Artur Azevedo, no começo do século XX, deixavam clara a intenção de manutenção do horizonte estético conhecido, de obediência às regras e convenções estabelecidas. O ator devia estar adequado ao seu tipo, no que diz respeito aos seus atributos físicos e ao seu jeito de representar, nesse caso um ator de comédia não devia se arriscar em um drama, o ator de operetas ficava deslocado em uma comédia; havia também a necessidade de adequação da peça ao gênero, se era uma revista devia obedecer às regras e tratar de assunto atual como era hábito nas revistas de sucesso do período. Era importante obedecer às convenções de maneira que o novo parecesse com o antigo. Em crônica escrita no final do século XIX, referindo-se ao público como “Zé”, o escritor declara:

O Zé não quer saber de coisas novas;

Dêem-se-lhe as velhas: ficará contente. ${ }^{38}$

Concedendo prioridade ao sentido de adequação, tanto para a cena quanto para o texto, o novo era desprezado, a transformação repudiada e as fórmulas conhecidas enaltecidas. O público precisava ser agradado a qualquer custo e com esse fim eram orientadas as produções artísticas. A crítica teatral se mostrava avessa a qualquer tentativa de transformação ou interpretação mais afiada do panorama teatral. Os espaços dedicados nos jornais e revistas para o teatro no país serviam muito mais para acompanhar polêmicas instauradas entre personagens do mundo teatral que, propriamente, para debater questões urgentes.

\section{A presença de Antoine no Brasil.}

Durante a visita do encenador francês André Antoine ao Rio de Janeiro, em 1903, ficava patente a postura conservadora e adepta de fórmulas consagradas defendida por Artur Azevedo e predominante no meio teatral brasileiro.

Antes da chegada da companhia houve nos jornais uma forte atenção ao fato, foram divulgadas notícias sobre o trabalho de Antoine, sobre os autores que seriam representados e sobre o repertório, considerado o que havia de mais atual na dramaturgia do período. Entre os autores que seriam apresentados no Teatro Lírico, estavam Henrik Ibsen, Jules

\footnotetext{
${ }^{38}$ Artur Azevedo, apud Flora Sussekind, obra citada, 1993, p.62
} 
Renard e Gerard Hauptmam. Além das apresentações, havia também marcada, durante a presença da companhia no Rio de Janeiro, uma conferência em que Antoine poderia expor seus princípios, suas idéias e o teor de suas pesquisas. Mesmo sendo o público brasileiro consumidor incontornável da cultura francesa, o trabalho de Antoine se diferenciava do que comumente chegava ao país, o que tornava as explicações sobre o seu trabalho ainda mais significativas.

Ao acompanhar a temporada do Teatro Antoine, Artur Azevedo, seguindo os ensinamentos do crítico francês Francisque Sarcey, insistia na receita da peça bem-feita como critério de julgamento do que assistia. O autor brasileiro acreditava que as tentativas de escrita cênica que despontavam na cena mundial, e que dispensavam as fórmulas consagradas, representavam "um assomo fugaz de independência e rebeldia” e que sem as antigas fórmulas não havia teatro possível. ${ }^{39}$ Azevedo lamentava as tentativas de transpor as experiências naturalistas do romance para o teatro, que constituíam os primeiros passos da dramaturgia moderna. Os comentários de Azevedo acerca do repertório trazido por Antoine giravam sempre em torno de considerações como essa, tentando encontrar nos textos as regras consagradas da "peça bem-feita”, os elogios sem ressalvas iam apenas para o desempenho dos atores: “A interpretação é completa, o tipo física e moralmente, de uma fidelidade absoluta". ${ }^{40}$

Nas descrições de Azevedo a respeito do trabalho de Antoine, pode-se destacar a tentativa de atenuar o aspecto de novidade de um trabalho que se mostrava de fato novo - já que nestes espetáculos estavam presentes importantes invenções no âmbito da dramaturgia e da encenação. Ou seja, a intenção de apontar como já visto aquilo que estava despontando na cena teatral e vinha representado pela figura de Antoine, como se tudo aquilo nos fosse conhecido e familiar, tanto em relação aos textos apresentados, quanto ao trabalho dos atores: "Sem o parecer à primeira vista, Brieux revela-se discípulo de Labiche, como este se revela discípulo de Scribe, e ambos de Moliére”. ${ }^{41}$ Sobre o aspecto naturalista da atuação, mesmo reconhecendo a habilidade de recursos dos atores da companhia, Azevedo retira,

\footnotetext{
${ }^{39}$ Artur Azevedo, “Antoine”. In: João Roberto Faria, obra citada, 2001, p.659.

${ }^{40}$ Idem, p.658.

${ }^{41}$ Idem, p.660.
} 
assim como faz com o repertório, a alusão de novidade da encenação apresentada pela trupe francesa:

O seu trabalho é completo como imitação da vida; o espectador esquece-se, realmente, de que está no teatro quando o vê e ouve; mas a mesmíssima impressão me causava, há vinte anos, a representação das peças de atualidade na Comédie Française: não creio que se possa representar naturalidade, com mais verdade, do que faziam Got, Coquelin, Delamay, Febvre, Thiron etc. ${ }^{42}$

Através de comentários como estes, o escritor acabava por atenuar o valor crítico do debate que poderia ocorrer em torno das experiências cênicas promovidas pelo teatro naturalista. “Artur parece se sentir na obrigação de cotidianizar - para si e para os leitores habituais - o que a rigor seria motivo de estranheza” ${ }^{43}$ E, através da atenuação da novidade trazida pelas montagens e pelo repertório de Antoine, mais uma vez Artur Azevedo defendia, junto aos seus leitores, o seu ponto de vista, impedindo que fosse posto em dúvida o seu modo de pensar o teatro.

O crítico demonstrava uma aceitação parcial das idéias do teatro moderno, ou seja, o desempenho dos atores, aquela tendência própria do naturalismo que buscava a verdade através da interpretação, da naturalidade da fala e dos gestos para a cena, era bem vinda. No entanto, os temas, o cuidado com o tratamento das situações expostas não pareciam cair bem entre os adeptos de um teatro feito exclusivamente para o agrado do público.

Nesta perspectiva, Artur Azevedo era seguido pelo escritor Olavo Bilac, que não exercia a função de crítico teatral, mas narrava suas experiências como espectador em crônicas na Gazeta de Notícias. Durante a temporada de Antoine no Brasil, Bilac enaltecia a interpretação dos atores - "representar assim não é só interpretar é viver” - e, ao mesmo tempo, apontava o repertório escolhido por Antoine como "uma fábrica de desesperos, de angústias e de tédio". ${ }^{44}$ A verdade no teatro, título de uma de suas crônicas, era somente aceita no âmbito da atuação. Enquanto a naturalidade nos gestos e a forma de viver os personagens agradavam ao escritor, os temas trazidos à cena pelo teatro naturalista, que

\footnotetext{
${ }^{42}$ Idem, p.660.

${ }^{43}$ Flora Sussekind, obra citada, 1993, p.84

${ }^{44}$ Olavo Bilac, “A verdade no teatro”. In: João Roberto Faria, obra citada, 2001, p.673.
} 
durante o século XIX haviam permanecido banidos das salas de espetáculos, eram considerados fastidiosos e até maléficos para um homem equilibrado.

O que desespera, no teatro moderno, é a secura, é a frieza implacável, é a inexorável dureza da sua verdade. Esse vocábulo, cujas três sílabas, depois da chegada do ator Antoine, estão em todas as penas, encobre e veste a fonte de toda a amargura e de todo o sofrimento. A verdade é a tristeza, é o nojo, é o enfaro. A verdade é amarga como o fel: e as abelhas do sonho, do amor, da felicidade, da alegria de viver não podem alimentar-se com esse fel, cujo travor as envenena e mata. ${ }^{45}$

O ideal de crítica social que fundamentava o teatro naturalista, representante dos primeiros passos de uma dramaturgia moderna, aparecia contrariando as expectativas românticas esboçadas pelo poeta. O debate proposto pelo Teatro Antoine expunha os dois pontos fundamentais dos rumos que o teatro poderia seguir a partir de então: de um lado o realismo romanesco, com temas ideais; do outro, não a idealização, mas a exacerbação do real, um estudo detalhado de situações dramáticas extraídas de problemas oriundos dos segmentos menos favorecidos da sociedade.

A especificidade da dramaturgia naturalista estava na "ambição de se encarregar da totalidade do real, e dela dar conta com exatidão”. ${ }^{46} \mathrm{O}$ drama naturalista buscava demonstrar a experiência do homem com o mundo à sua volta, o autor não apontava mais sentimentos e estados de espírito conhecidos, através dos quais o receptor podia se sentir satisfeito; ao contrário, desafiava o espectador a enxergar e a se reconhecer em um mundo repleto de situações cruéis e inusitadas. Desta maneira, os experimentos teatrais do período buscavam a tomada de consciência por parte dos espectadores acerca de aspectos cruciais da realidade.

Outra questão levantada pelo naturalismo, e que marcou decisivamente a trajetória de modernização da cena teatral, foi a forte oposição proposta por estes artistas ao “academicismo congelado”, às convenções antigas proclamadas e respeitadas pelo teatro europeu.

\footnotetext{
${ }^{45}$ Idem, p.674.

${ }^{46}$ Jean-Jacques Roubine, Introdução às grandes teorias do teatro. Rio de Janeiro, Jorge Zahar Ed., 2003, p.111.
} 
O mérito do naturalismo no teatro terá sido, sobretudo, o de irrigar boa parte das pesquisas do século XX, particularmente relativizando esse respeito estrito pelas regras de boa fabricação, da qual Dumas Filho fazia o alfa e o ômega da arte teatral. Ali onde este identifica a construção dramática a um teorema, o naturalista aconselha que não se preocupe além da conta com receitas velhas. Sua própria eficácia as torna no fundo suspeitas. ${ }^{47}$

A teoria naturalista, através do questionamento ao consagrado, liberou a encenação e a dramaturgia de uma herança imponente de coerções diversas. A lógica utilizada por autores como Eugène Scribe, Victorien Sardou, Emile Augier e Alexandre Dumas Filho, modelos elogiados por Azevedo, e representados incansavelmente durante os séculos XIX e XX no Brasil, representava, segundo defensores da estética naturalista, a habilidade do escritor em seguir receitas velhas, em conseguir carregar o espectador em suas mãos, mesmo com uma trama inverossímil.

O Sr. Dumas Filho, que é antes de mais nada o que se chama homem de teatro, nunca hesita entre a realidade e uma experiência cênica; ele torce o pescoço da realidade. Sua teoria é que pouco importa a verdade, contanto que se seja lógico. Uma peça se torna um problema a ser resolvido; parte-se de um ponto, é necessário chegar a um outro, sem que o público se irrite; e a vitória é completa se se foi bastante hábil para saltar por cima dos obstáculos, forçando o público a segui-los mesmo a contragosto. ${ }^{48}$

As expectativas de um realismo ingênuo eram negadas combativamente pelos defensores do teatro naturalista. A mesma frustração de expectativas observada em Bilac pode ser, portanto, notada em relação a Artur Azevedo. As fórmulas consagradas, as receitas de sucesso garantido junto ao público que precisava ser agradado a todo custo viam-se desrespeitadas; a idéia de diversão, como único objetivo ligado à arte, se tornava fortemente criticável. O teatro naturalista, se não renovou amplamente a dramaturgia, transformou intensamente o sentido da representação. Não era mais possível pensar o teatro

\footnotetext{
${ }^{47}$ Idem, p.113.

${ }^{48}$ Émile Zola, O romance experimental e o naturalismo no teatro. São Paulo, Perspectiva, 1982, p. 114.
} 
sem interrogar as condições e a finalidade da representação e sem assumir a presença e a participação do espectador no evento.

Assim como as reformas sofridas pela cidade do Rio de Janeiro pouco contribuíram de fato para melhorar as condições de vida da população, o mesmo se dava com a importação das idéias teatrais européias no início do século. As idéias naturalistas apareciam no cenário teatral brasileiro, porém de forma fragmentada, compreendidas pela metade, sem conseguir transformar essencialmente o pensamento artístico do período. A interpretação naturalista, que trazia o tom cotidiano para as falas e tirava o jeito declamado do texto, era compreendida como um avanço e até reconhecida como já praticada entre os atores nascidos por aqui; entretanto, os temas que o naturalismo trazia para a cena, as questões sociais, a análise de problemas de classes desfavorecidas que aproximavam o teatro da realidade, eram vistos como maléficos. Importávamos do teatro estrangeiro a forma de atuar, os gestos e a maneira de falar, mas deixávamos de lado as suas dissidências críticas. A quebra de horizonte de expectativas sugerida pela visita do encenador francês e pelo repertório apresentado não foi pequena, e foi esta a principal causa da negação das inovações do naturalismo. Na recusa a estes experimentos, podemos enxergar os primeiros aspectos do veto, que ganha força nas décadas posteriores, a qualquer investigação artística que se mostrasse apta à efetiva modernização da cena teatral brasileira.

\section{Repúdio ao vedetismo.}

O trabalho dos atores, tão observado por Azevedo e Bilac durante a visita de Antoine, era, como vimos, importante via de combate que o teatro naturalista seguia em busca da renovação das artes cênicas. O encenador francês apontava em seus escritos para a necessidade de pensar o teatro como um trabalho em grupo, buscava consolidar a criação em equipe e erradicar dos palcos a idéia de atores vedetes, que tanto atrapalhavam a evolução do teatro moderno. As fórmulas recorrentes de atuação, solidificada entre os atores experientes - as caras e bocas conhecidas e utilizadas como truques para conquistar o público, os recursos fisionômicos e vocais pré-estabelecidos -, eram apontados, tal como as receitas dramatúrgicas da peça bem-feita, como obstáculos que precisavam ser superados. 
A interpretação desejada pelo teatro naturalista pedia mais sobriedade, concisão e, obviamente, verdade. Assim, os truques de declamação, os gestos pré-concebidos, os arranjos de movimentação no palco evitando que os atores dessem as costas para a platéia, os lugares previamente estabelecidos para personagens principais e secundários, os figurinos elegantemente portados, mas que nada diziam a respeito das personagens retratadas, precisavam sair de cena. Antoine desejava que os atores fizessem viver os personagens dentro de suas existências cotidianas e para isso não utilizassem somente o rosto e a voz, mas colocassem o corpo em ação, reconhecendo a capacidade expressiva de cada gesto, de cada movimento.

Rigorosamente moldados pelos movimentos rudimentares e primitivos de nosso teatro clássico, deformados para sempre pela cena de "fúria" ou de "sonho", esses atores ignoram a complexidade, a variedade, as nuanças, a vida do diálogo moderno, seus meandros, suas frases, suas entonações indiretas, seus subtextos, seus silêncios eloqüentes. ${ }^{49}$

O encenador francês considerava os antigos procedimentos de atuação uma "herança nefasta”, e postulava como necessários, a disciplina, o estudo minucioso do texto e a aquisição de intimidade com a obra. A expressividade dos intérpretes e os jogos de cena desejados por Antoine solicitavam uma investigação cuidadosa, um trabalho lento e complexo desenvolvido nos ensaios. O desempenho dos atores, a partir de então, precisava estar em consonância com a encenação, em busca de coerência e unidade para o espetáculo. Os truques e macetes dos velhos atores, que solicitavam a todo custo a aprovação do público, deveriam desaparecer, em seu lugar surgiriam criações subordinadas ao movimento geral da obra, "o sentido de conjunto não deve ser entravado por nada, nem pela espera do ponto, nem por uma preocupação de efeitos pessoais”. ${ }^{50}$

Ao negar as expectativas de um público habituado a homenagear os primeiros atores das companhias em detrimento do conjunto do espetáculo, o encenador deixava clara a sua intenção de propor preceitos estéticos diversos daqueles estabelecidos por outras companhias estrangeiras que por aqui aportavam.

\footnotetext{
${ }^{49}$ André Antoine, Conversas sobre a encenação. Trad. Walter Lima Torres. Rio de Janeiro, 7Letras, 2001, p.38.

${ }^{50}$ Idem, p.39.
} 
Em sua conferência proferida no Teatro Lírico, no Rio de Janeiro, Antoine retomou o assunto, destacou o fato de que não era o desempenho dos atores o que a sua companhia apresentava de mais importante e sim a dramaturgia escolhida: "Não são os artistas e sim os autores do Théâtre Libre e do Théâtre Antoine que aqui se acham em excursão". ${ }^{1}$ A companhia francesa apresentava em seu repertório, no lugar de melodramas com desfecho esperado e de aceitação fácil, dramas que buscavam estimular o espectador a refletir, por reconhecer em cena, não intrigas da vida privada, mas questões urgentes das sociedades contemporâneas.

Os nossos autores compreenderam e sentiram que após todo o esplendor, depois de todo o prestígio estéril da forma, da imaginação e da fantasia, o público moderno, já então mais educado, lhes pedia outras novelas menos pueris, escritas não para embalar e adormecer a sua miséria e o seu labor, mas, pelo contrário, para estimular seu esforço; para acostumar cada qual ao livre exame de si próprio e dos outros, fazendo nascer no coração do homem a audácia de se aperfeiçoar e de viver melhor. $^{52}$

A cena teatral precisava estar carregada de uma vontade questionadora dos padrões sociais e estéticos vigentes. Portanto, não seria razoável esperar que o estímulo ao livre exercício do juízo crítico se desse de maneira doce e agradável para os espectadores. Antoine tocava, desta maneira, em dois pontos cruciais da prática teatral exercida em nosso país, e que estavam intimamente relacionados: demonstrava o quanto estava ultrapassado o status do primeiro ator da companhia, polarizador de toda a representação; e sublinhava como fundamental a efetivação de um diálogo entre o palco e a platéia, diálogo nem sempre bem recebido, por sua contundência, mas absolutamente necessário.

O repúdio ao estrelismo em cena não era uma invenção do teatro naturalista de Antoine e sim prerrogativa comum em todas as vanguardas teatrais da Europa. A posição central e absoluta do ator, que ocupava o palco como se este fosse apenas uma moldura para a sua performance, se colocava na contracorrente das inovações do teatro. Da mesma maneira, o espetáculo que buscava apenas o regozijo do público mostrava-se contrário às

\footnotetext{
${ }^{51}$ Idem, p.46.

${ }^{52}$ Idem, p.48.
} 
novas prerrogativas das investigações cênicas que despontavam desde os fins do século XIX. A relação do espectador com o espetáculo se apresentava como uma das grandes indagações do teatro moderno e o evento teatral, a partir de então, deixava de significar oferecimento de fórmulas conhecidas para o agrado certo de um público homogêneo. Ou seja, ao questionarmos o posicionamento da crítica e do público perante os elementos apontados por Antoine em ocasião de sua visita ao Brasil, estamos de fato nos perguntando como as primeiras idéias modernas de encenação, que contagiavam o teatro europeu e traziam o espectador para o centro do debate, chegavam ao país.

\section{Regras personalistas e facilitação do diálogo com o espectador.}

Os dois pontos principais levantados por Antoine para a efetivação de um teatro moderno pareciam bater de frente com o que era comumente aceito e prestigiado por aqui. A figura do primeiro ator continuava a grassar em nossos palcos, e, quanto ao desafio de promover obras que quebrassem a lógica burlesca da intriga e do qüiproquó, não tínhamos tampouco exemplos animadores. Qualquer experiência efetiva de renovação teatral era rapidamente recusada. Ao fomentar a experimentação, destronando o primeiro ator, e ressaltar a atitude dos autores dramáticos por ele apresentados, que trabalhavam obedecendo a si próprios, "rejeitando as regras, desdenhando das fórmulas correntes” e "sem a preocupação do êxito" ${ }^{\text {, } 33}$ o encenador francês desafiava as normas caducas que prevaleciam na cena teatral brasileira.

O ensaiador, figura presente desde o início do século XIX, no teatro brasileiro, era o responsável pela marcação dos espetáculos, traçava a "mecânica cênica”, dispondo os móveis e objetos necessários à ação e determinando a movimentação dos atores em cena; “papel bem marcado, dizia-se, meio caminho andado”. ${ }^{4}$ A movimentação dos intérpretes resultava menos das necessidades apontadas pela dramaturgia ou pela encenação do que da hierarquia dos atores, que devia ser respeitada dentro da cena. O centro do palco era reservado à estrela da companhia, os segundos atores ficavam nas regiões intermediárias e os figurantes, na periferia. Eventualmente um ator podia atravessar o espaço do outro, mas

\footnotetext{
${ }^{53}$ Idem, p.58.

${ }^{54}$ Décio de Almeida Prado, O teatro moderno brasileiro. São Paulo, Perspectiva, 2003, p.16.
} 
deveria sempre retornar ao seu lugar de origem. "A marcação, uma vez fixada, podia repetir-se ao infinito, pela mesma ou por outras companhias”. ${ }^{5}$

O diretor e dramaturgo Renato Vianna, em sua segunda iniciativa pela mudança do teatro, ao constituir sua companhia dramática, em 1924, intitulada Colméia, tentava nadar contra a corrente da realidade teatral do período. Em busca de resultado diverso para o seu trabalho, deu-lhe o estatuto de um grupo teatral, transformando assim o processo de feitura do espetáculo. A nova forma buscada por Vianna para as suas montagens resultaria de uma nova ideologia. "Essa ideologia vinha de braços com a noção de conjunto e de interdependência das funções”. ${ }^{6}$ Ou seja, Vianna buscava erradicar o virtuosismo da estrela, como fundamento de concepção do espetáculo e, desta forma, construir uma cena renovada. No programa de ação desta Companhia podia-se ler:

[A Colméia] tentará eximir-se à prática de tudo o que seja repercussões de hábitos e vícios inveterados no meio profissional; procurará que as representações sejam a soma certa do trabalho de cada intérprete seu. Não fazendo atrair as atenções da publicidade para qualquer nome de artista em especial, mas para os nomes do elenco, pois segundo a sua orientação, cada qual é uma parcela do esforço inteligente para a realização do ideal comum, só terá em mira defender a todo transe o conjunto da representação. ${ }^{57}$

A tentativa modernizadora de Vianna, modificando os procedimentos de criação, representava um contra-senso diante do que era comumente executado entre nós. "Era a primeira vez, no Brasil, que se propunha organizar uma companhia objetivando o conjunto da representação". ${ }^{58}$ A Colméia não teve vida longa, porém a postura defendida por seu criador apontava para importantes revisões acerca da compreensão do evento teatral, já que as renovações propostas na feitura do espetáculo apontavam para a tentativa de pensar o trabalho dos atores em sua relação com a encenação, o que alterava de maneira relevante a recepção do espetáculo, pois o público precisava se concentrar no conjunto da cena e não em personagens (ou atores) isolados e auto-suficientes.

\footnotetext{
${ }^{55}$ Idem, p.17.

${ }^{56}$ Sebastião Milaré, A batalha da Quimera:estudo sobre o teatro de Renato Vianna, São Paulo, obra inédita, 2001, p.83.

${ }^{57}$ Programa do grupo teatral A Colméia. In: Sebastião Milaré, obra citada, p.83.

${ }^{58}$ Sebastião Milaré, obra citada, p.84.
} 
Ao questionar o estrelismo dos ditos "grandes atores”, Renato Vianna não estava apenas se posicionando a favor de uma nova maneira de pensar a produção teatral em termos da organização dos artistas - o que já seria um fato notável e marcadamente moderno -, mas também atento a como a quebra da hierarquia dos atores influenciava decisivamente a constituição da cena, pois a liberdade de ocupação do palco pelos atores, quebrada esta hierarquia da estrela, possibilitava a constituição de um discurso cênico refinado, que poderia valer-se da ação física e da movimentação dos atores por todo o palco. Desta maneira, Vianna mostrava-se atento à necessidade de democratização do teatro, tanto no âmbito da produção, com a plena participação de todos os artistas no processo, quanto na ampliação do diálogo estabelecido entre palco e platéia, através de uma construção cênica livre das pressões habituais exercidas pelos atores-empresários.

Ao contrário do projeto idealizado por Vianna, os fundamentos críticos dos textos que acompanhavam as montagens, em sua maioria, desmereciam o conjunto do espetáculo e colaboravam sobriamente para a consolidação da visão oitocentista de um teatro voltado para a exaltação do primeiro ator.

Desde Artur Azevedo, existia um roteiro para a crítica que continuava sendo utilizado pelos resenhistas nas décadas seguintes: fazia-se primeiro um resumo do enredo, posteriormente, comentários sobre o elenco, por fim, era feita uma apreciação a respeito da afluência do público, da quantidade de aplausos recebidos, etc. Porém, se houvesse em cena um desses atores célebres, a atenção voltava-se somente para ele, para os detalhes de sua interpretação.

A senhora Itália Fausta não tardou em aparecer. Vinha, súplice, em procura do perdão. Foi suave, resignada. Desesperou-se. Vimo-la, depois, gasta, viciosa, má e muito desgraçada; em seguida, violenta e criminosa. Depois foi a encarnação do desespero e de amargura, até morrer de dor e, em tudo quanto fez, disse e exprimiu, foi admirável, perfeita, extraordinária. ${ }^{59}$

Os outros companheiros do elenco eram avaliados nesses casos pela forma como contracenavam com o primeiro-ator ou com a primeira-atriz da companhia. A marcação

\footnotetext{
${ }^{59}$ Mário Nunes, obra citada, p.119.
} 
também podia receber elogios, caso tivesse possibilitado, com a movimentação adequada, uma boa visibilidade de cada artista em foco e a perfeita audibilidade do espetáculo.

Num período em que domina um "teatro de atores", em que até as marcações cênicas obedeciam à necessidade de se deixar o "primeiro ator" da companhia sempre um passo à frente dos demais, sempre em posição central, em que os ensaiadores se limitavam praticamente a dar a cada ator um papel adequado ao seu tipo físico e à sua especialidade, não é de estranhar que boa parte dos críticos se submetesse às regras personalistas da vida teatral de então. ${ }^{60}$

Seguindo as "regras personalistas", a dramaturgia produzida tinha que servir aos empresários, aos atores e ao público. Os autores dramáticos deviam arranjar as suas peças de forma que a personagem principal da trama pudesse realçar o brilho deste ou daquele ator. Além disso, era conveniente que o desenvolvimento do enredo ficasse concentrado no personagem principal para não diluir a atenção do público entre os outros atores, o primeiro ator não podia ser ofuscado pelo crescimento de outras personagens. A trama devia ser bem-encadeada, seguindo a lógica da carpintaria teatral, conduzida através de conflitos facilmente solucionáveis e com tipos correspondentes aos encontrados nas companhias teatrais, como a ingênua, a criada, o galã, etc.

Para interpretar os papéis criados especialmente para eles, os atores não precisavam de um estudo minucioso. Variavam as falas, as peripécias, mas a linha geral do desempenho já estava pronta, devido à repetição do tipo de personagem que lhes eram encomendados. Os astros das companhias trabalhavam a partir de gestos e inflexões conhecidos anteriormente pelos espectadores, e, enquanto os atores secundários utilizavam perucas, bigodes e barrigas falsas para encarnar os seus tipos, os atores principais, na maioria das vezes, apareciam com o mesmo rosto, sem elementos diferenciadores da sua aparência cotidiana.

Os cômicos de primeira linha (...) apresentavam ao público, a vida inteira, salvo ligeiras modificações, a mesma imagem, o rosto e as inflexões que os espectadores tinham aprendido a admirar e a querer bem. ${ }^{61}$

\footnotetext{
${ }^{60}$ Flora Sussekind, obra citada, 1993, p.73.

${ }^{61}$ Décio de Almeida Prado, obra citada, 2003, p.21.
} 
O público, por sua vez, subjugado em sua capacidade crítica através de espetáculos facilmente digeríveis, se comprazia em reconhecer os trejeitos de seus atores e atrizes preferidos em cena.

A vaidade do intérprete, em suma, coincidia com o seu interesse comercial. Identificar o artista, física e psicologicamente, conhecer-lhe os sestros, as manhas, era um prazer que não convinha negar às platéias. ${ }^{62}$

A lógica de não negar prazeres simples à platéia e de enaltecer a figura do ator na frente de outras prioridades, reduzia o campo de investigações do teatro, esmaecendo a sua potencialidade reflexiva. O público, diante de um espetáculo feito exclusivamente para não causar espanto, via-se dirigido para uma assistência complacente de enredos esperados, sem que nenhum esforço de leitura lhe fosse demandado.

Em suma, as "regras personalistas” que movimentavam a vida teatral acabavam se transformando em uma espécie de veto artístico às inovações cênicas que poderiam transformar a prática teatral do período, o mando e desmando dos atores configurava-se como controle ao que podia e ao que não podia ser produzido no meio teatral, deixando marcas nas atividades dos autores, artistas e espectadores.

Leopoldo Fróes se destacava neste cenário de culto aos "monstros sagrados”. O ator, sempre elogiado pela sua presença no palco, pela movimentação elegante em cena, era famoso pelos seus macetes, pela sua forma de atuar sem decorar as falas, sem dedicar tempo para o estudo do personagem ou para o conhecimento profundo do texto. Nas palavras de Viriato Correa, Fróes foi, em seu tempo, o consagrador dos “cacos”.

Não tive a felicidade de vê-lo em papel estudado, a não ser em Um beijo nas trevas, peça de gênero gran-guignol. Sempre titubeante, disfarçava o titubeio ora com cacos, ora com seu brilho

${ }^{62}$ Idem, p.21. 
natural. Ninguém como ele soube disfarçar a falta de estudo de um papel. Às vezes, por não saber uma linha de suas falas, dava aos personagens defeitos de elocução. ${ }^{63}$

Se o primeiro ator podia se dar ao luxo de inventar textos em cena aberta, o mesmo não era permitido aos demais componentes, que precisavam se ajustar aos seus hábitos para decifrarem o momento em que deveriam pronunciar o texto, sair ou entrar em cena. A possibilidade exclusiva de improvisação servia como mais um indicador da hierarquia entre ele e os demais atores. "A companhia coagida a respeitar o texto, trabalhava como podia para dar sentido à história e se ajustar às invenções do protagonista” ${ }^{64}$ Os textos montados pelas companhias lideradas por Leopoldo Fróes eram escolhidos com base em dois critérios: possuírem papéis masculinos que realçassem o seu tipo e estarem totalmente adequados ao gosto vigente.

A relação entre Fróes e a platéia era pautada pela noção de mercadoria ofertada a consumidores. "Leopoldo Fróes viveu entre duas épocas do teatro brasileiro e simbolizou a implantação histórica dos atores como produto de consumo”. ${ }^{65}$ Se Fróes se assumia como tal, disposto a atender aos gostos mais fáceis do seu público, este, por sua vez, se via cada vez mais afundado na condição de mero consumidor. Com a desculpa de atendimento às solicitações do público, os atores-empresários contribuíam para a falta de participação do mesmo enquanto produtor da obra; subjugava-se o espectador e negava-se "à arte seu duplo caráter transformador: de si mesma e de seus fruidores”. ${ }^{66}$

Fróes deixava claro o caráter de comercialização com o qual encarava o trabalho artístico, por isso escolhia peças de sucesso já experimentadas em outros cantos do mundo, não deixando de reconhecer e, ao mesmo tempo, negar aquelas que se distanciavam do horizonte já conhecido.

Há peças que constituem o meu ganha-pão, o meu negócio e outras que são os meus luxos, a minha fantasia. (...) De um lado, as peças estrangeiras de sucesso bem verificado, bem garantido e as nacionais, de fortes, infalíveis qualidades dramáticas, ou hilariantes - e do outro lado os nossos

\footnotetext{
${ }^{63}$ Viriato Correa, apud R. Magalhães Jr., As mil e uma vidas de Leopoldo Fróes. Rio de Janeiro, Lisa,1971, p.44.

${ }^{64}$ Sérgio Ricardo de Carvalho Santos, O drama impossível. Tese de doutoramento em Literatura Brasileira. Faculdade de Letras e Ciências Humanas da Universidade de São Paulo, 2002, p.33.

${ }^{65}$ Idem, p.33.

${ }^{66}$ Edwaldo Cafezeiro \& Carmem Gadelha, História do teatro brasileiro. UFRJ/Funarte, 1996, p.445.
} 
jovens autores, bem dotados, mas ainda não orientados, os poetas, os estilistas, natural ou até propositadamente avesso às regras e convenções teatrais, os talentos, em suma, que como artista, me seduzem, mas, como empresário, fatalmente me dão prejuízo. ${ }^{67}$

Ao imaginar o prejuízo causado por espetáculos inovadores que exigissem mais empenho por parte dos atores e espectadores, Fróes acabava optando por textos de sucesso garantido, que não se chocassem com o que era considerado bom pela maioria e que por isso mesmo fossem de sedução fácil. Desta maneira, o ator assumia um sintoma que acompanhava o teatro do seu tempo: as peças que quebravam as convenções estavam fadadas ao fracasso.

A adesão aos matizes modernos que se dava em parte na sociedade, importando da Europa aspectos selecionados das novas condições histórico-sociais, aparecia também na postura do ator-empresário. Fróes deixava as prerrogativas críticas de lado e adotava como modernização do teatro apenas a velocidade das montagens impostas pelo mercado. Era possível acelerar o tempo das produções, encaixá-las no mesmo ritmo frenético que tomava conta da sociedade: "em sete meses e meio, de meados de maio a 31 de dezembro, Fróes montou exatamente vinte e uma peças”. 68

O critério de escolha do repertório do ator, aplaudido intensamente por jornalistas da época, exemplificava, por vias inversas, o sistema de reconhecimento do valor estético de uma obra. Segundo a estética da recepção, como vimos, quanto mais próxima a obra aparece do horizonte de expectativa já conhecido menor o seu valor estético, e menor também o seu potencial provocativo e emancipador. Para o ator-empresário, as mesmas circunstâncias desvalorizadoras do caráter artístico da obra, a tornavam, justamente, mais interessantes, enquanto as tentativas avessas às regras e convenções significavam escolhas impossíveis.

Em artigo publicado em 10 de janeiro de 1905, Artur Azevedo havia abordado a mesma questão, ao esclarecer que tipo de interlocutor tinha em mente quando escrevia as suas crônicas e a preocupação constante em agradá-los:

Desde que pela primeira vez me aventurei a rabiscar nos jornais observei que a massa geral dos leitores dividia-se em dois grupos distintos: um muito pequenino, muito reduzido, de pessoas

\footnotetext{
${ }^{67}$ Leopoldo Fróes, apud R. Magalhães Jr., obra citada, p.107.

${ }^{68}$ R. Magalhães Jr., obra citada, p.44.
} 
instruídas ou ilustradas, que procuravam em tudo quanto liam gostoso pasto para os seus sentimentos estéticos, e outro numeroso, formidável, compacto, de homens de trabalho, que iam buscar na leitura dos jornais um derivativo para o cansaço do corpo e exigiam que não lhes falassem senão em linguagem simples, que eles compreendessem. Observei também que o primeiro grupo não concorria absolutamente para a prosperidade dos jornais, pois que nem ao menos tinha o costume de comprá-los sistematicamente, ao passo que o segundo comprava e assinava, lia e fornecia o assunto, isto é, a alma, a vida da nossa indústria jornalística. Tendo que escolher os meus leitores entre esses dois grupos, naturalmente escolhi os do segundo, e desde então fui assaltado pela preocupação de lhes agradar escrevendo de modo que eles entendessem e não se arrependessem de me haver lido. ${ }^{69}$

Com estas palavras, Azevedo poderia se referir também à sua produção teatral; afinal de contas, as revistas de ano tinham suas semelhanças com o jornalismo e guardavam o mesmo princípio dos periódicos, já que eram sempre baseadas em acontecimentos atuais. Porém, preocupado em agradar leitores e espectadores, atingindo-os de forma premeditada, facilitando o acesso através de textos de fácil compreensão, o escritor não contribuía para o adensamento do diálogo estabelecido entre obra e receptor.

Da mesma maneira que Leopoldo Fróes reconhecia, como empresário teatral, que os textos dramáticos livres de convenções e regras possuíam qualidades literárias, podendo até serem descritos como "a poesia do teatro”, mas lhe levariam a ruína e, por isso, preferia investir em textos de "sucesso bem verificado", Artur Azevedo optava pela massa de leitores consumidores. Os dois personagens da história do teatro brasileiro, autor e empresário teatral, explicavam suas opções por questões de mercado, por necessidade de garantir a venda de suas produções.

Com o aparecimento de Flores de Sombra, peça de Cláudio de Souza, que estreou em 22 de dezembro de 1916, no Teatro Boa Vista, em São Paulo, houve uma verdadeira comemoração entre os críticos teatrais: finalmente o teatro brasileiro encontrava a sua dramaturgia, uma dramaturgia que engrandecia os valores nacionais e convocava o público ao teatro.

${ }^{69}$ Artur Azevedo, apud Fernando Antonio Mencarelli, Cena aberta, Editora da Unicamp, 1999, p.156. 
Há mais de vinte anos, no Brasil, uma peça nacional não obtém tal êxito. Mesmo entre as peças de maior sucesso de Artur Azevedo e outros saudosos autores do nosso antigo teatro, nenhuma comédia nos ocorre que tenha alcançado tão grande triunfo no palco brasileiro. ${ }^{70}$

Comemorava-se o excelente resultado de bilheteria da peça - 108 apresentações consecutivas no Rio de Janeiro, o que era um recorde para a época - e comemorava-se também a plena satisfação do público. O critério de valor da obra vinculado unicamente à prerrogativa de sucesso e popularidade era comum no período, como ainda o é, em larga escala, nos dias de hoje, tanto na análise das encenações do presente, quanto na valoração das produções do passado. Flores de Sombra foi a primeira de muitas peças com temas e formas semelhantes que consagraram o gênero Trianon como o de maior sucesso nas primeiras três décadas do século XX.

Convencionou-se chamar o gênero de teatro leve sem pretensões, feito exclusivamente para rir, de "gênero" Trianon. Oriundo de mestres da carpintaria teatral como Cláudio de Souza, Gastão Tojeiro, Armando Gonzaga, e Abadie Faria Rosa, que tiveram grandes sucessos no antigo 'Teatro Trianon', com Cristiano de Souza, Leopoldo Fróes e depois Procópio Ferreira, esse gênero perpetuou-se entre nós, tomando o nome do teatro. ${ }^{71}$

Importa ressaltar que quanto mais popularizados os dramaturgos e atores teatrais se encontravam, mais antipopulares as suas propostas artísticas se tornavam. Ou seja, a popularidade obtida através de espetáculos estandardizados acabava por diminuir a capacidade crítica e formadora de espectadores que pode possuir a obra de arte. "O caráter de arte de massas marcou decisivamente a produção cultural da chamada geração Trianon”. ${ }^{72}$ Os artistas abriam mão de qualquer possibilidade artística que não garantisse a certeza de grande afluência de espectadores e intenso aplauso da crítica. A aproximação entre o público e a obra através de uma adequação ao gosto popular constitui-se em uma falsa idéia de aproximação. Os sucessos estrondosos dos empreendimentos teatrais, que começavam a se desenvolver no Brasil, significavam antes uma separação, aprofundava-se de fato o fosso que separava palco e platéia.

\footnotetext{
${ }^{70}$ João Luso, apud R. Magalhães Jr., obra citada, p.63.

${ }^{71}$ Brício de Abreu, apud Edwaldo Cafezeiro \& Carmem Gadelha, obra citada, p.441.

${ }^{72}$ Edwaldo Cafezeiro \& Carmem Gadelha, obra citada, p.444.
} 
O espectador se aproxima da obra, ou é lançado ao encontro do acontecimento artístico, quando tem o seu gosto frustrado, quando se vê diante de uma obra capaz de lhe proporcionar uma experiência estética efetiva, isto é, quando se depara com algo que nega o esperado. A maneira pela qual uma obra artística, no momento histórico de sua aparição, “atende, supera, decepciona ou contraria as expectativas de seu público oferece-nos claramente um critério para a determinação de seu valor estético”. ${ }^{73}$ Entretanto, não podemos supor, a partir desta afirmativa acerca do valor estético de uma obra, que possamos deixar de lado as inúmeras obras que mesmo sem quebrarem o horizonte estético conhecido no período de sua elaboração efetivaram experiências ricas e duradouras para com os seus receptores. A afirmativa de Jauss em prol de uma arte transgressora de limites propõe a releitura daquelas que não obtiveram a atenção merecida, justamente por não apresentarem opções estéticas facilmente degustáveis.

\section{Alcântara Machado: uma outra crítica.}

A critica teatral tem importância fundamental para a nossa pesquisa, dado que ela não apenas documenta as impressões que determinado espetáculo causou em seu tempo, como também possui caráter formador, repercutindo tanto na recepção contemporânea, quanto em recepções futuras.

Se a crítica documenta a história dos efeitos da obra, responsabiliza-se igualmente por esses últimos, sob este aspecto correspondendo com mais nitidez ao papel ativo que a estética da recepção espera conferir ao leitor. ${ }^{74}$

Nesse sentido, para a análise que pretendemos fazer acerca da experiência receptiva dos embates modernos no teatro brasileiro, torna-se de crucial importância a observação do papel da crítica do período, assim como perceber quando os fundamentos conservadores desta documentação apareciam contornados. A trajetória traçada por Alcântara Machado, que exerceu a função de crítico teatral no Jornal do Commércio de São Paulo, entre os anos

\footnotetext{
${ }^{73}$ Hans Robert Jauss, obra citada, 1994, p.31.

${ }^{74}$ Regina Zilberman, obra citada, p.101.
} 
de 1923 e 1926, representa a construção de um pensamento que caminhava na contramão dos fundamentos conservadores da recepção artística do período.

Arte não se faz assim do pé para a mão. É necessário um preparo lento, bem orientado e metodizado. Do contrário o fracasso é certo, se não comercial, pelo menos artístico. ${ }^{75}$

Alcântara buscou, em diversos escritos sobre a arte teatral, realizar um estudo minucioso acerca da dramaturgia e das regras que a legitimavam naquele período. Adepto dos ideais modernistas, apontou a necessidade do teatro em abandonar as formas antigas, em desprezar as receitas melodramáticas fartamente conhecidas, assim como a necessidade de repúdio aos atores estrelas das companhias e à mercantilização como critério único da produção artística.

Em artigo publicado na Revista Nova, no ano de 1932, intitulado “Leopoldo Fróes”, o escritor fez um apanhado sobre a atuação deste artista no teatro brasileiro. Entre outras observações, deixava clara a crítica ao senso comercial apurado do ator - "diante dele, a ganância dos empresários entregava os pontos logo de início” -, ao mau gosto da dramaturgia apresentada desde o princípio de sua carreira - "escolheu um repertório quase todo de bobagenzinhas parisienses” -, e à forma desabrida com que realizava modificações nos textos por ele apresentados - “colaborava no diálogo e (o que é pior) alterava o entrecho como bem entendia”. ${ }^{76} \mathrm{O}$ impulso de Fróes em mexer nos textos era atribuído à necessidade de facilitar ainda mais a história para o entendimento imediato dos espectadores, mesmo que para isso ficasse comprometido o conjunto da peça.

Por tudo isso, a contribuição de Fróes ao teatro brasileiro se tornava desmerecedora de elogios. Segundo o crítico, o ator não tinha sido capaz de participar da transformação do teatro, de trazer investigações cênicas de outros países - colaborando para a modernização da cena brasileira -, de construir personagens que não fossem aqueles tipos característicos. Não arriscou uma interpretação fundada em outros parâmetros que não os relacionados com sua personalidade vaidosa e autoritária, e, sobre a literatura dramática, importou o que havia de pior.

\footnotetext{
${ }^{75}$ Antonio Alcântara Machado, apud Sérgio Ricardo de Carvalho Santos, obra citada, p.39.

${ }^{76}$ Idem, p.204.
} 
Alcântara Machado argumentava que, nesse impulso de servir aos ideais comerciais de seu tempo, de corresponder ao tipo galã-cômico, Leopoldo Fróes havia perdido a oportunidade de aprofundar as nuances de seu trabalho de comediante. Talento que havia provado possuir quando criou personagens bem caracterizadas para as peças: $O$ genro de muitas sogras, de Artur Azevedo; Simpático Jeremias, de Gastão Tojeiro; e Quebranto, de Coelho Neto. Nesses trabalhos, Fróes havia se colocado como um artista interessado em desvendar as possibilidades de suas performances, buscando apresentar-se diferentemente de sua própria figura, utilizando-se de outras inflexões vocais e outros gestos, conduta incomum entre os primeiros atores das companhias, que não se davam ao trabalho de criar personagens, já que as suas construções não deviam se distanciar da sua própria figura.

Da mesma maneira que a relação de concessão estabelecida entre palco e platéia afastava o público receptor da produção, e contribuía negativamente para a construção de um diálogo eficaz entre espetáculo e espectador, a imposição absorvida pelos atores, especialmente pelas estrelas, de agradar ao público com tipos estandardizados, os afastavam da possibilidade de um trabalho criativo em suas composições cênicas.

Tomando Flores de Sombra como antimodelo, Alcântara Machado apontou diversas renovações urgentes para a vitalização do teatro na sociedade de então. Entre elas, notava a necessidade de uma dramaturgia crítica, que mostrasse a realidade tal qual se apresentava e descrevesse os personagens com esta mesma fidelidade. Alcântara não compartilhava a opinião de um teatro feito para que os espectadores pudessem esquecer o que se passava do lado de fora. Ao contrário, buscava lugar de destaque para uma teatralidade nova, crítica e relacionada com os novos tempos, na qual o contato efetivo entre arte e realidade era encarado como premissa de fundamental importância. "Para Alcântara Machado o bom teatralismo deveria conduzir para a observação das relações da vida”. ${ }^{77} \mathrm{O}$ realismo pretendido no texto de Cláudio de Souza, aplaudido intensamente pela crítica contemporânea - "os críticos ficaram deslumbrados com o espetáculo, mesmo os mais severos e independentes estavam de queixo caído"78 -, era apontado como exemplo a ser negado, um retrato falso da realidade, povoado de figuras clichês e sem um pingo de verdade. Mesmo sem deixar claro em seus escritos, o seu pensamento parecia muito mais

\footnotetext{
${ }^{77}$ Sérgio Ricardo de Carvalho Santos, obra citada, p.70.

${ }^{78}$ R.Magalhães Júnior, obra citada, p.63.
} 
contagiado pelas idéias naturalistas conhecidas no Brasil através de Antoine do que ele próprio apontava.

O modelo de encenação de Alcântara Machado, tal como estava sendo pensado de forma fragmentária em seus artigos, esteve muito mais próximo da pesquisa antiburguesa e antidramática do socialismo de Antoine do que da cena teatralista purificada de Copeau, ainda que algumas de suas opiniões expressas possam indicar o contrário. ${ }^{79}$

Outra questão que surge nos escritos de Alcântara de maneira incisiva é a urgência em acabar com a estrutura do drama burguês, quebrando as regras da carpintaria dramática e, com isso, negando as expectativas do público em relação à evolução da trama. A estrutura dramática que desenvolvia a trama seguindo uma ordem crescente - primeiro o estabelecimento da intriga, em seguida o seu ponto culminante, e por fim a resolução - e abusava dos golpes de efeito preparadores para um final sempre emocionante, servia apenas para satisfazer o público em suas expectativas mais fáceis e eram assim desclassificadas pelo crítico.

A peça partia do informe, ia aos poucos tomando corpo e terminava sempre com uma situação nítida que esclarecia o conflito e não deixava dúvida alguma no espanto do espectador. Partia de um ponto desconhecido para alcançar um objetivo certo desvendando o caráter das personagens ou o pensamento do autor. De forma que o drama realmente acabava caído o pano. O público saía sem se preocupar com o destino das figuras que via em cena. O futuro estava patente no desenlace. O teatro contemporâneo, no entanto, quebrou essa regra. O pano sobe depois do conflito armado. $\mathrm{O}$ espectador tem a impressão de que chegou atrasado. E o pano desce sem marcar o final. O drama continua. ${ }^{80}$

Ao colocar em questão a eficiência da carpintaria dramática e a ordenação causal das cenas, o crítico mostrava-se atento à necessidade de destruição e reconstrução da estrutura do drama e, ao mesmo tempo, colocava em debate o diálogo que esta dramaturgia nova poderia estabelecer com a sua platéia. O agrado certo do público, a necessidade de corresponder a todo custo ao gosto vigente defendido entre os críticos da geração anterior, virava espaço de embate e não de aceitação para o crítico modernista.

\footnotetext{
${ }^{79}$ Sérgio Ricardo de Carvalho Santos, obra citada, p.68.

${ }^{80}$ Alcântara Machado, apud Sérgio Ricardo de Carvalho Santos, obra citada, p.59.
} 
Em texto sobre a obra de Ibsen, Alcântara nos deixa perceber a distância entre a sua crítica e a efetuada por Artur Azevedo no final do século XIX. Azevedo, em artigo escrito em 1899, negava a Ibsen o título de revolucionário do teatro, dizia que suas peças pareciam inspiradas nos dramas realistas franceses: “A Casa de Bonecas de todas elas a mais apreciada pelas platéias latinas, é um misto de Augier, Dumas e Meilhac e Halévy”. ${ }^{81}$ Sobre o desfecho da peça, Azevedo não deixava de reconhecer que havia beleza no final construído pelo dramaturgo norueguês, porém acreditava que era um final sem desenlace, “o que me repugna é que ele não esteja convenientemente preparado”. ${ }^{82}$ A transformação sofrida pela personagem principal representava uma mudança brusca demais, que não acontecia aos poucos, de forma a convencer os espectadores que o desenlace construído pelo autor significava uma conseqüência lógica do desenvolvimento da ação. Nestas opiniões, Azevedo era seguido por outros críticos brasileiros da época, que apontavam para a falta de coerência da peça.

Percebe-se nos julgamentos dos folhetinistas, que ficaram incomodados com o fato de Ibsen não se sujeitar às famosas convenções e mesmo assim conseguir comover e interessar o espectador mais atento. ${ }^{83}$

O horizonte de expectativas que participava da recepção aos dramas de Ibsen, no Brasil do final do século XIX, estava baseado na lógica da peça bem-feita. Seguindo esta lógica, cada acontecimento aparecia ligado a outro, de forma, presumidamente, tão exata entre causa e conseqüência que a figura do autor desaparecia. A história só podia terminar quando esta ação, nitidamente definida, chegasse ao fim. A carpintaria dramática, com sua lógica causal, baseada em uma teia de ações e reações, não previa espaços para outros desfechos que aquele sugerido pelo autor.

Casa de Bonecas, escrita em 1879, quebrava assustadoramente a estrutura dramática e com o final inesperado frustrava qualquer possibilidade de contentamento da platéia. Nora, a protagonista da peça, ao olhar para o passado, ganhava condições de modificar o

\footnotetext{
${ }^{81}$ Artur Azevedo, “Entre Sarcey e Ibsen”. In: João Roberto Faria, obra citada, 2001, p.643.

${ }^{82}$ Idem, p.650.

${ }^{83}$ João Roberto Faria, obra citada, 2001, p.236.
} 
seu presente, ou melhor, dando voz ao passado da personagem o autor quebrava o presente contínuo e irreversível estabelecido na lógica da estrutura dramática, e concedia à personagem atitude inesperada e transformadora do próprio destino. A sobreposição de passado e presente permitia a transformação do futuro, e era assim que a peça terminava. A ação não se encerrava com a descida do pano, como observou depois Alcântara Machado, “o pano desce sem marcar o final”. Antes de convencer, o drama construído por Ibsen chocava os espectadores.

Alcântara Machado conseguia perceber que, longe de ser um defeito, o desfecho da peça apontava para a subversão das convenções da estrutura rigorosa do drama; colocava em xeque a construção determinista dos fatos e buscava transgredir a seqüência dos atos, preconizada como obrigatória pelas peças bem-feitas e seguidas durante décadas. Compreendendo as inovações do drama realizadas no teatro europeu, Alcântara apontava como virtude aquilo que Azevedo apontara como defeito.

O espanto do espectador era reconhecido pelo crítico como algo a ser cultivado no drama moderno. A experiência estética via-se, portanto, redimensionada a partir da análise empreendida por Alcântara Machado. Através do choque causado no espectador, proporcionado pela imprevisibilidade dos acontecimentos, pela frustração do horizonte expectativo tornava-se mais concreta a possibilidade de transformação do ponto de vista do espectador.

Tanto para o progresso da ciência quanto para o avanço da experiência da vida, o momento mais importante é o da frustração de expectativas: elas se assemelham à experiência de um cego que se choca com um obstáculo, descobrindo assim a sua existência. Graças ao defraudamento de nossas suposições, nós tomamos contato com a realidade. ${ }^{84}$

Ao negar modelos dramáticos como Flores de Sombra e ao questionar as peças do gênero Trianon, exemplos extremos de sucesso de bilheteria no teatro brasileiro, Alcântara Machado mostrava descaso para com o que era considerado modelo de sucesso, apontava a importância de observar com desconfiança os espetáculos louvados pela crítica e, além disso, se colocava atento ao debate moderno acerca das renovações necessárias, de forma e

\footnotetext{
${ }^{84}$ Hans Robert Jauss, obra citada, 1994, p.52.
} 
conteúdo, que o texto teatral precisava ser submetido, para que uma relação efetiva, e não apenas ornamental, fosse estabelecida entre a cena e a sociedade.

\section{O moderno nas entrelinhas.}

A estética da recepção propõe que a história da arte não se contente em descrever o encadeamento cronológico das obras, mas que conceda atenção ao âmbito da recepção e do efeito. A repercussão negativa de uma obra pode, antes de desvalorizar o valor artístico da obra, realçar o seu efeito, esclarecer o quanto a suposta obra negou o horizonte de expectativa de seu tempo. A reconstrução de um horizonte expectativo do passado permite reconhecer quando as obras mostram-se submetidas às normas e convenções de seu tempo, ou quando as mesmas se colocam de forma revolucionária, negando tais sistemas de normas vigentes. Quando uma obra, no momento histórico de sua aparição, se vê recusada pelo seu público inicial, não significa que a mesma não foi concretizada. O que se nota é que a recusa por parte do público representa a sua primeira concretização e que, além disso, as informações acerca desta maneira com que foi recebida inicialmente influenciam recepções futuras.

A idéia defendida neste trabalho, ao aproximar os conceitos da estética da recepção do teatro moderno brasileiro, possui dois aspectos principais. O primeiro é notar o quanto o horizonte de expectativa do período - tal como podemos observar através dos fundamentos da crítica, das regras personalistas que acompanhavam a prática artística e das informações sobre a sociedade que buscava modernizar-se sem livrar-se da lógica colonial - se colocava contrário a qualquer tipo de inovação, a qualquer possibilidade de quebra de convenções. Um horizonte contaminado pela idéia de assimilação do imaginário europeu, porém, sem aceitar o cunho crítico das experiências modernas de vanguarda. O segundo aspecto é que, mesmo com pouca repercussão, ou mesmo sem terem sido encenadas, as obras artísticas de cunho moderno que tomaram forma no início do século tiveram a sua concretização efetivada. Uma concretização marcada pela recusa, mas nem por isso desconfigurada, que se deu nas entrelinhas dos acontecimentos teatrais do período, e que deve ser procurada nos fracassos, nas experiências frustradas ou proibidas, nas investigações que não receberam o aplauso da crítica, nos textos não levados à cena. 
As experiências modernas engendradas por autores e pensadores teatrais que buscavam um teatro crítico em sua relação com a sociedade, que almejavam fugir dos clichês relativos às tramas e aos personagens, que traçavam tentativas de diálogo intenso com a platéia, representaram a modernização, ainda que sem repercussão positiva, da cena teatral no país. A recusa aos lances modernos do teatro brasileiro por parte da maioria dos críticos e espectadores do período, não neutraliza o movimento moderno ocorrido entre nós, mas antes representa a forma como este foi concretizado.

As condições inóspitas com que foram recebidas estas ações modernas no teatro brasileiro nos fornecem elementos para pensarmos a relação entre arte e sociedade no Brasil, entre tentativas de transformação estética e projeto social conservador, entre inovações artísticas e contexto histórico retrógrado, tendo em mente que "sair do clichê é um gesto com implicações tanto estéticas quanto sociais”. ${ }^{85}$

Se, no Brasil, o teatro sempre esteve vigiado de perto pela censura, já que desde o início do século XIX, com a regulamentação das casas de espetáculos, regulamentou-se também a censura aos espetáculos teatrais, durante a República o que se nota é o acirramento de medidas coercitivas relacionadas ao âmbito das artes e dos meios de comunicação, o que pode ser avaliado através dos inúmeros decretos e órgãos criados durante as primeiras décadas do século XX.

No ano de 1924, passou a ser exigido dos empresários teatrais ou dos diretores de espetáculos uma licença emitida pela polícia para que pudessem trabalhar. A licença seria dada desde que fossem reconhecidos pelas autoridades a idoneidade e os bons antecedentes dos indicados. A existência dessa licença não implicava no relaxamento da fiscalização das autoridades policiais, além do que, para estas autoridades, deveriam ser reservados camarotes especiais disponíveis em todos os espetáculos. Esse mesmo decreto regularizava a função do censor, que a partir de então seria nomeado pelo Ministro da Justiça, e, ao mesmo tempo, estabelecia as gratificações que deveriam ser pagas pelos empresários e diretores teatrais a estas autoridades. A censura "passava a render dividendos”. ${ }^{86}$ Em 1928, a censura teve a sua prática ainda mais especificada. Garantia-se agora que, uma vez liberado o espetáculo, ficava proibido qualquer tipo de alteração no texto; para comprovar a

\footnotetext{
${ }^{85}$ Luiz Costa Lima, Mímesis e modernidade. São Paulo, Editora Paz e Terra, 2003, p.97.

${ }^{86}$ Cristina Costa, Censura em cena. São Paulo, EDUSP/FAPESP/Imprensa oficial do Estado de São Paulo, 2006, p.88.
} 
obediência dos artistas, o censor comparecia aos ensaios gerais. Essa norma perdurou durante toda a República. A partir de 1937, com a instauração do Estado Novo, a burocracia de controle dos meios de comunicação chega ao auge. "Eram sujeitas à censura até mesmo as excursões de artistas ao exterior”. ${ }^{87}$

A censura no teatro brasileiro via-se configurada de forma explícita, através de órgãos criados para vigiar a produção cultural no país, e também de forma implícita, quando analisamos os fundamentos da crítica teatral que não se deixava contagiar pelas prerrogativas da modernidade em suas dissidências críticas, e também quando levantamos dados acerca da relação entre artistas, empresários e público teatral.

Se seguirmos o esquema autor-obra-intermediário-público, concluiremos que a primeira ação da censura se efetua na relação entre o autor e a obra, no momento da produção. Essa operação do mecanismo censor é tão importante que pode ser identificada com uma palavra específica: autocensura. ${ }^{88}$

Através das argumentações de críticos, dramaturgos e atores brasileiros, é possível supor os efeitos da autocensura em seus trabalhos. Uma espécie de censura não explícita, mas interiorizada "com tal eficácia que o autor nem sequer indaga sobre as possibilidades de comunicação de uma mensagem; suprime-a ou disfarça-a inconscientemente”. ${ }^{89}$

O surgimento da censura, e de órgãos especialmente criados para aplicá-la, mostrase como um indicador duplo: por um lado, revela que a sociedade em que ela aparece apresenta tensões em suas relações sociais; "por outro lado, evidencia que a atividade cultural e artística superou sua inocuidade e participa dos conflitos". 90

A história do teatro brasileiro do início do século XX precisa ser examinada tendose em mente, especialmente, as diversas formas de censura e veto aplicadas às experiências modernas sonhadas por uma geração, e não a partir da constatação de inexistência de produções modernas no teatro realizado naquele período. Os empecilhos encontrados pelos artistas para o desenvolvimento pleno de suas investigações cênicas - a falta de compreensão dos críticos para a análise de encenações modernas, avaliações feitas a partir

\footnotetext{
${ }^{87}$ Idem, p.110.

${ }^{88}$ Nestor Garcia Canclini, obra citada, p.126.

${ }^{89}$ Idem, p.127.

${ }^{90}$ Idem, p.123.
} 
de critérios retrógrados, os órgãos especializados em controle e censura que acompanhavam as atividades artísticas etc. - explicitam a efetividade destas experiências artísticas, e atestam o enfrentamento travado com as regras e normas estabelecidas, que constituíam o horizonte estético do período. 


\title{
Capítulo 2
}

\section{Vigência e exceção na cena brasileira}

\begin{abstract}
A tradição dos oprimidos nos ensina que o “estado de exceção” em que vivemos é na verdade a regra geral. Precisamos construir um conceito de história que corresponda a essa verdade.
\end{abstract}

Walter Benjamin

Um dos argumentos freqüentemente utilizados para invalidar o advento do modernismo em países periféricos como o nosso, nas primeiras décadas do século XX, se situa no modo de constituição de nossas sociedades, que ainda não estariam suficientemente maduras para tal realização. Atribui-se, pois, à falta de condições históricas imediatas a não efetivação de uma vanguarda teatral entre nós, não considerando como modernas as inovações realizadas por alguns de nossos artistas, sob a justificativa de que não havia em nosso país as mesmas condições histórico-sociais observadas em países europeus. Se assim for, como podemos distinguir as iniciativas artísticas de alto teor inventivo e com marcantes características vanguardistas que foram efetivadas nas produções dramatúrgicas e cênicas de artistas como Oswald de Andrade e Flávio de Carvalho, consideradas ainda mais radicais do que as produções de décadas posteriores, que receberam dos historiadores o cunho de "modernas"? A história do teatro brasileiro, desde os anos 1920, possui, além disso, outros dados de experiências artísticas - sem reconhecimento de público e crítica -, que efetivaram propostas francamente modernas na cena teatral.

Uma concepção de história assim definida parte do pressuposto de uma finalidade e de um percurso previamente estabelecidos para as tensões e trajetórias próprias a cada uma das sociedades. Como se houvesse um caminho previamente traçado: ou escrito pelas sociedades ditas "avançadas", que serviriam de modelo a ser seguido pelos países periféricos - em uma noção de tempo linear e homogêneo, com feição causal e determinista, 
próprio da "historiografia burguesa"1 -; ou estabelecido por um modo de pensamento dito de esquerda, que compreende a história com um sentido racional que a estrutura e que é por fim alcançado - "no caso, a vitória final do proletariado - e transforma o tempo histórico num desenrolar determinado por esse advento seguro".2

Da mesma maneira que a arte pode ser antecipatória, quando apresenta questões históricas e formais para além de seu tempo imediato - "quando antecipa caminhos da experiência futura, imagina modelos de pensamento e comportamento ainda não experimentados ou contém uma resposta a novas perguntas”33 -, o artista, também, precisa ser considerado como sujeito capaz de atuar historicamente, capaz de surpreender, sujeito não meramente determinado pelas condições sociais imediatas. A história se enriquece quando compreendida em suas tensões particulares, em que inovações e antecipações são sempre possíveis. Os atores sociais possuem a capacidade de romper expectativas, mesmo condicionados pelas circunstâncias. Pois, “o que tem acontecido até hoje não predetermina o que vai acontecer amanhã. O sujeito dispõe da possibilidade de surpreender”. ${ }^{4}$ O que não pressupõe que as produções artísticas possam se dar sem diálogo com as condições históricas de suas sociedades, ou sem relação com as realizações artísticas de seu tempo. A experiência artística elabora uma espécie de jogo com as outras obras e com as características históricas marcantes; nesse jogo, a obra ora confirma as idéias predominantes e ora contesta. De uma maneira ou de outra, apresenta-se em diálogo com o contexto histórico e com as formas artísticas que vigoraram em determinada época e na sociedade em que foi concebida.

Não existe um modernismo por excelência, mas variadas possibilidades de modernismo. A noção de moderno não pode ser tomada a partir de padrões previamente estabelecidos, pois se faz necessário reconhecer e compreender a sua efetivação segundo questões e resoluções próprias a cada sociedade.

\footnotetext{
${ }^{1}$ Walter Benjamin, Obras escolhidas. Magia, técnica, arte e política. São Paulo, Brasiliense, 1993.

2 Jeanne Marie Gagnebin, Walter Benjamin: memória, história e narrativa. In: Mente, Cérebro e Filosofia. São Paulo, Duetto, nº 7, 2008, p. 63.

${ }^{3}$ Hans Robert Jauss, A história da literatura como provocação à teoria literária. São Paulo, Ática, 1994, p.39.

${ }^{4}$ Leandro Konder, Walter Benjamin. O Marxismo da Melancolia. Rio de Janeiro, Ed. Campus, 1989, p.7.
} 
Particularmente os países ocidentais, que avançaram mais rapidamente que os outros no caminho da modernidade, devem reconhecer, ao mesmo tempo, que eles não detêm o monopólio da mesma e que a modernidade está presente também nas outras formas de modernização, com exceção daquelas que se opõem totalmente a ela. ${ }^{5}$

Ou seja, as efetivações do moderno teatro entre nós precisam ser compreendidas a partir de padrões - e contra estes padrões - estabelecidos tanto nas condições históricas brasileiras, quanto nas formalizações artísticas que predominavam em nosso teatro. Pois, por mais que possua linhas gerais de efetivação, a modernidade possui características marcantes surgidas em face da sociedade que a aloja.

A contrariedade é uma das características marcantes desse movimento estético multifacetado, tanto no âmbito dos comportamentos e atitudes sociais, quanto na superação das formas artísticas em voga. "O antigo, seja ele uma canção popular, seja uma forma literária caída em desuso, pode se tornar moderno na medida em que negar a tradição imperante e propor algo novo". 6

No caso do teatro, o final do século XIX e o início do século XX correspondem a um período de transformações profundas para a cena, momento marcado pela necessidade de rompimento de normas respeitadas durante décadas. A renovação da dramaturgia que se opera nesse período está marcada pelo aguçamento da relação entre o que se passa no palco e o que se passa na vida social, o que significa a possibilidade de encontrarmos nos palcos não apenas o espelhamento de dilemas da vida privada, típicos do "drama burguês" ${ }^{7}$, mas a apresentação de mazelas que não se situam no interior dos gabinetes, mas do lado de fora e que se relacionam com o âmbito coletivo.

As invenções modernas na dramaturgia estão intimamente relacionadas a essa mudança de foco, do drama individual para o drama coletivo e social. O teatro do século XIX, descrito por Oswald de Andrade como "um minarete de paixões pessoais, uma simples magnésia para as dispepsias mentais dos burgueses bem jantados”, ${ }^{\circledR}$ entra em decadência cedendo lugar a um teatro que participa dos debates sociais. O drama moderno surge justamente quando a forma dramática fechada e rigorosa, fundada nos conflitos do

\footnotetext{
${ }^{5}$ Alain Tourrane, Um Novo Paradigma. Petrópolis, Vozes, 2006, p.241.

${ }^{6}$ Octavio Paz. Os filhos do barro. Rio de Janeiro, Nova Fronteira, 1984, p.20.

${ }^{7}$ Peter Szondi, Teoria do drama moderno. São Paulo, Cosac e Naify, 2001.

${ }^{8}$ Oswald de Andrade, apud Sábato Magaldi, obra citada, 2004, p.61.
} 
diálogo intersubjetivo, entra em crise. A lógica de causalidade perde a sua estabilidade; o desenrolar da ação não acontece de forma esperada, pronta para confirmar as expectativas da platéia; o passado invade o presente da cena e as personagens, capazes de surpreender, tomam decisões inesperadas sem que a sua transformação tenha sido gradativamente preparada. A trama perde a ordem pré-estabelecida de início, meio e fim; procedimento bem definido nas palavras do escritor e crítico teatral Antonio Alcântara Machado: “o pano sobe depois do conflito armado. O espectador tem a impressão de que chegou atrasado. E o pano desce sem marcar o final. O drama continua”. 9

Levando-se em conta a especificidade de cada país em construir a sua modernidade e, ao mesmo tempo, o padrão geral de análise do modernismo no teatro, que localiza o drama moderno surgido da crise do drama burguês - o qual se detinha em problemas relacionados à vida íntima -, podemos nos perguntar: como foi aclimatada em nossa sociedade a forma dramática rigorosa? Onde estava o nosso teatro burguês, retratista da vida privada brasileira, e, por conseqüência, como se estruturou a "crise do drama” na nossa cena de acordo com nossas especificidades históricas e formais?

No caso do teatro brasileiro, quando nos propomos a discutir acerca da efetivação de suas propostas modernas, precisamos, portanto, refletir sobre as particularidades que esse discurso estético encontrou ao ser recepcionado entre nós. Numa sociedade como a nossa, marcada por abismos existentes entre os seus componentes, e entre estes e a República $^{10}$, o drama - gênero relacionado aos valores da autonomia burguesa - não podia se estabelecer tal como se estabeleceu em outros países. "Diante de uma sociedade sem campos de diferença para o reconhecimento do outro, a forma do drama (gênero baseado nos conflitos do diálogo intersubjetivo) será sempre de difícil transposição”. 11

O drama no Brasil encontrou uma efetivação própria, que se via marcada pelas ambigüidades sociais, pela desigualdade de direitos entre a população e pela falta de interesse por mudanças reais por parte da classe dirigente. Adaptado a uma "sociedade

\footnotetext{
${ }^{9}$ Alcântara Machado, apud Sérgio Ricardo de Carvalho Santos. Obra citada, p.59.

${ }^{10}$ José Murilo de Carvalho, Os bestializados. São Paulo, Companhia das letras, 2006, p. 37.

${ }^{11}$ Sérgio Ricardo de Carvalho Santos, O drama impossível. Tese de doutoramento em Literatura Brasileira. Faculdade de Letras e Ciências Humanas da Universidade de São Paulo, 2002, p. 11.
} 
cosmopolita e provinciana, moderna e antiquada, liberal e oligárquica”12, o modernismo no teatro brasileiro ganhou contornos específicos que precisam ser desvendados.

Uma das maneiras de representação dos impasses que marcavam a sociedade brasileira nesse período foram os registros cômicos que dominaram diversos meios de comunicação no período inaugurado pela Abolição e pela República. Eles significavam não apenas mais uma forma de representar a realidade, mas uma forma privilegiada de retratar as condições de vivências e sociabilidades cotidianas no país.

O cômico correspondia à busca de uma singular e peculiar forma de representação, pois como representar e simbolizar a vida privada e individual no interior daquela indefinida comunidade imaginada chamada Brasil $?^{13}$

No caso da imprensa, a tradição da representação humorística vinha dos folhetins cômicos da Regência e do Segundo Reinado, e se aprofundou com o aparecimento das revistas ilustradas no início do século XX. As produções teatrais utilizavam-se bastante das revistas ilustradas, que já haviam incorporado nesse período a fotografia, tanto para divulgação de espetáculos, quanto para apresentação de “perfis” de determinados atores, que davam nessas colunas notícias de seus trabalhos, viagens e interesses artísticos. Não era raro encontrar humoristas de jornais que também se aventuravam pelos palcos acumulando em si mesmos “as figuras de caricaturista de imprensa, publicitário, revistógrafo e, não raro, de ator”. ${ }^{14}$. Como exemplos dessa sobreposição de funções aparecem, entre outros, Raul Pederneiras, K Lixto e Luis Peixoto.

Esses registros cômicos de representação apareciam, de maneira hegemônica, na cena teatral brasileira no início do século XX e participavam da difícil transposição do drama para uma sociedade como a nossa. As comédias que predominavam em nossos palcos se estruturavam através do modelo das peças bem-feitas, isto é, incorporavam os princípios do drama burguês, com estrutura bem encadeada e voltada para discussões no âmbito da vida privada. Essas peças, como poderemos observar, representavam a constituição do drama burguês, em chave cômica, no teatro brasileiro. Da mesma maneira -

\footnotetext{
12 Elias Thomé Saliba, A dimensão cômica da vida privada na República. In: Nicolau Sevcenko (org.). História da vida privada no Brasil 3. São Paulo, Companhia das Letras, 1998, p. 297.

${ }^{13}$ Idem, p. 305.

${ }^{14}$ Idem, p. 298.
} 
mas se colocando de forma contrária ao teatro aplaudido em nossos palcos - as experiências modernas surgidas por aqui apareciam também marcadas por esses registros cômicos. $\mathrm{O}$ teatro moderno entre nós se estabeleceu no diálogo com estas comédias - a partir delas e contra elas -, ou seja, as experiências modernas efetivadas por aqui se utilizavam também da chave cômica, ao mesmo tempo em que se colocavam em tensão com esta estética dominante, pois contrariavam os princípios formais de uma dramaturgia linear e homogênea adotados por essas comédias.

Daí encontrarmos em Oswald de Andrade a comicidade associada à quebra da estrutura causal, o "riso ferino no lugar da lágrima generosa"15 e “a montagem de fragmentos explodindo o doce equilíbrio da linearidade" ${ }^{16}$ Ou observarmos ainda a irônica atuação de Flávio de Carvalho, em meados dos anos 1931, em ato denominado Experiência $n^{\circ} 2$, que, ao acompanhar uma procissão de Corpus Christi que se realizava no centro da cidade de São Paulo, caminhava no meio da multidão, só que na direção contrária. Imagem que pode ser tomada como metáfora para afirmar a utilização do registro cômico, tanto em nossas comédias, que funcionavam como um drama com final feliz, quanto em nossos lances teatrais modernistas, que se valiam dessa comicidade para criticar o estabelecido.

\section{O princípio dramático adotado pelas comédias.}

O teatro brasileiro dos anos imediatamente anteriores ao modernismo é descrito comumente pelos críticos como um momento de predomínio de dois tipos de espetáculos: por um lado, os musicais do teatro de revista e, por outro, as comédias de costumes ou as comédias ligeiras, especialmente aquelas encenadas no teatro Trianon, que os críticos batizaram com o nome de Gênero Trianon, justamente pelo espaço em que eram apresentadas. De uma maneira ou de outra, no teatro cantado ou declamado, a cena teatral brasileira estava predominantemente marcada pelo registro cômico.

As comédias do Trianon, oriundas "de mestres da carpintaria teatral como Cláudio de Souza, Gastão Tojeiro, Armando Gonzaga, Heitor Modesto e Abadie Faria Rosa”,17, que

\footnotetext{
${ }^{15}$ Luiz Costa Lima, “Ficção: as linguagens do modernismo”. In: Ávila. Affonso, O modernismo. São Paulo, Perspectiva, 1975, p. 71.

${ }^{16}$ Idem, p. 71.

${ }^{17}$ Brício de Abreu, apud Edwaldo Cafezeiro e Carmem Gadelha. História do teatro brasileiro: de Anchieta a Nelson Rodrigues. Rio de Janeiro, Editora UFRJ - Funarte, 1996, p.441.
} 
obtiveram enorme sucesso de público e crítica no período, aparecem muitas vezes descritas como "teatro leve, feito sem pretensões estéticas". Temos o intuito de investigar aqui, contudo, como essas comédias "feitas exclusivamente para rir" incorporavam os princípios dramáticos da alta comédia, se afastavam das formas populares de teatro e, dessa maneira, tornavam-se legítimos representantes do nosso drama burguês, constituído em chave cômica.

Nas críticas aos espetáculos do Trianon, em jornais da época, no período que vai de 1915 a 1921, podemos observar uma espécie de conclusão, nos comentários críticos, que se repetem várias vezes: “agradou muito, pois fez rir a valer”. ${ }^{18}$ Ao mesmo tempo em que tinham como objetivo principal fazer a platéia rir, as comédias apresentadas nesse teatro procuravam se diferenciar do teatro de cunho popular, buscando um público mais “refinado" que aquele que comparecia, por exemplo, ao teatro de revista. Ao escrever uma comédia que seria apresentada no teatro Trianon em fevereiro de 1917, o autor Raul Pederneiras explicou em nota enviada ao jornal as características de seu novo texto:

Por seu gênero e pelo local a que se destina, é uma pequena pochade, para a platéia fina, que freqüenta o Trianon, passar uma hora alegre, nesse interregno carnavalesco. Para isso fiz a revista um pouco afastada dos moldes populares, rematando-a com uma apoteose de fantasia delicada. ${ }^{19}$

Quanto mais diferentes dos espetáculos que freqüentavam os palcos dos teatros de revista essas comédias parecessem, melhor seriam avaliadas pela crítica. A única ressalva que fez o crítico e dramaturgo R. Magalhães Jr. à peça Flores de sombra, de Cláudio de Souza - que estreou em São Paulo em 1917, com 50 representações sucessivas, fato inédito na história do teatro naquela cidade, e que depois realizou longa temporada de sucesso no Rio de Janeiro, inaugurando o chamado Gênero Trianon -, estava relacionada à semelhança que esta adquiria, em algumas tiradas cômicas, com cenas do teatro de revista:

Quando o Possidônio, mandado em busca de um cozinheiro competente, capaz de atender às exigências dos hóspedes, acostumados à cozinha francesa, vem dar conta de sua missão, a platéia

\footnotetext{
${ }^{18}$ Adriano de Assis Ferreira, Teatro Trianon: forças da ordem $x$ forças da desordem. Dissertação de mestrado, Departamento de Teoria Literária e Literatura Comparada, Universidade de São Paulo, 2004, p.119. ${ }^{19}$ Raul Pederneiras, apud Adriano de Assis Ferreira. Obra citada, p. 176.
} 
ri, ri muito. Mas a graça rebaixa a peça. Não é graça de comédia: é graça de revista ou de picadeiro. $^{20}$

Mesmo sendo algumas vezes tratada como "chanchada"21, o tipo de comédia produzida pelos autores dramáticos que constituía o chamado gênero Trianon, distanciavase dos procedimentos do teatro de revista e aproximava-se da estrutura da peça bem-feita acrescida de conteúdo moralizante. Em artigo no Jornal do Commércio, de 1915, o teatro era descrito como "o preferido de nossa melhor sociedade”22, possuidor de uma platéia “composta do que há de elegante e chic na sociedade carioca - todos os camarotes repletos de um público fremente”. ${ }^{23}$ Essa comédia, pensada de forma a se afastar de procedimentos adotados pela farsa, que busca tratar de temas ligados à moral e aos bons costumes, que se ocupa em divertir “a fina flor da nossa sociedade”, e apresenta uma história engraçada, mas que "não escandaliza e nem a ninguém faz corar" 24 , tinha tradição no teatro brasileiro.

Em meados do século XIX, José de Alencar havia explicado, em artigo publicado no Diário do Rio de Janeiro, o impulso obtido para escrever sua primeira comédia, utilizando-se da mesma expressão que aparece na crítica teatral da Gazeta de Notícias, de 1920. Alencar apontava que a vontade de escrever uma comédia nascera-lhe quando estava na platéia do teatro diante de uma farsa. A peça, segundo o escritor, extrapolava os limites da moral e dos bons costumes e fazia a platéia rir, mas era um riso que aparecia acompanhado de rubor. Incomodado com a situação, Alencar havia se perguntado: "Não será possível fazer rir sem fazer corar?”. ${ }^{25}$ A imagem utilizada pelo escritor para explicar o seu ímpeto dramatúrgico possuía em sua narrativa um didatismo próprio: Alencar não somente relatava a sua experiência, mas aproveitava para recomendar a mesma preocupação para aqueles que se aventurassem nos rumos da dramaturgia.

Através de suas crônicas ao sabor da época, repletas de conselhos, Alencar acompanhava com entusiasmo o movimento teatral na cidade do Rio de Janeiro. Com a inauguração do Ginásio Dramático, no ano de 1855, recomendava aos seus leitores que

\footnotetext{
${ }^{20}$ R. Magalhães Jr., As mil e uma vidas de Leopoldo Fróes. São Paulo, Lisa, 1971, p.54.

${ }^{21}$ Edwaldo Cafezeiro e Carmem Gadelha, obra citada, p.443

22 Jornal do Commércio, 29/03/1915, apud Adriano de Assis Ferreira, obra citada, p.119.

${ }^{23}$ O País, 02/04/1916, apud Adriano de Assis Ferreira, obra citada, p.149.

${ }^{24}$ Gazeta de Notícias, 24/03/1920, apud Adriano de Assis Ferreira, p.235.

${ }^{25}$ José de Alencar “A comédia brasileira”. In: João Roberto Faria. Idéias teatrais: o século XIX no Brasil. São Paulo, Perspectiva/Fapesp, 2001, p.468.
} 
freqüentassem os espetáculos promovidos neste teatro, assegurando que na "balaustrada dos seus camarotes se debruçam as senhoras mais elegantes, as moças as mais gentis dos nossos aristocráticos salões”. ${ }^{26}$ A casa de espetáculos, que funcionava nos mesmos moldes do Gymnase Dramatique de Paris, trazia para a Corte as principais comédias realistas francesas e, a partir de então, seria este o principal tipo de comédia aprovada e defendida, não somente por Alencar, mas por diversos jornalistas e escritores da época, para representar o teatro nacional.

Podemos dizer que nas décadas de 1850 e 1860 a dramaturgia brasileira, que mal começara a existir na década anterior, já enfrenta em completa desigualdade de condições a luta que na Europa durou cerca de dois séculos pela imposição do princípio burguês do drama, ao preço da expulsão, condenação, excomunhão e perseguição das “formas populares” do teatro. ${ }^{27}$

Desde então o teatro brasileiro viu-se empenhado em construir uma dramaturgia baseada nos princípios do drama rigoroso, na estrutura fechada do drama tradicional. Os espetáculos do Ginásio Dramático, respeitando as regras da peça bem-feita, com lógica causal e desdobramentos bem amarrados, eram aclamados como modelos para a produção dramatúrgica nacional, seja pelo prazer do público ou pela satisfação da crítica, que podia construir análises a partir de parâmetros franceses. O novo repertório ali apresentado chegou causando entusiasmo nos habitantes da capital fluminense, os quais, desanimados com a falta de novidades que marcava a vida teatral no período, depositavam esperanças de renovação e desenvolvimento da atividade teatral na empresa nascente. Primeiramente, o Ginásio apostou nas pequenas comédias e vaudevilles de Scribe, e, posteriormente, nas comédias mais longas de autores franceses, como Alexandre Dumas Filho, Émile Augier, Théodore Barriére, entre outros. As questões discutidas pelos dramaturgos realistas franceses se referiam principalmente ao universo da burguesia, "classe com a qual se identificavam e para a qual dirigiam a sua produção". ${ }^{28}$ Ao lado das descrições dos costumes burgueses, surgia a prescrição de valores éticos, como o trabalho, a honestidade, o casamento e a família.

\footnotetext{
${ }^{26}$ José de Alencar, Ao correr da pena. São Paulo, Melhoramentos, s/d, p.271.

${ }^{27}$ Iná Camargo Costa, Sinta o drama. Petrópolis, Vozes, 1998, p. 130.

${ }^{28}$ João Roberto Faria, O teatro realista no Brasil. Perspectiva, São Paulo, 1993, p.26.
} 
Entre os personagens destes dramas de casaca apareciam como heróis os pais de família, os jovens sensatos e as moças honestas; e como vilões o agiota, a prostituta e o jogador. Havia ainda o raisonneur, personagem característico do drama realista, fundamental dentro da trama, cuja função era a de observar a ação e emitir lições moralizantes aos outros personagens e, por conseqüência, ao público. O espelhamento da realidade nessas peças surgia amenizado, poupado de seus aspectos mais grotescos, justamente pela intensa função moralizante que acompanhava as primeiras obras da escola realista francesa. Combinando divertimento e lições moralizantes, as peças realistas apareciam no Brasil como termômetro de civilização, estética do mundo desenvolvido, a qual devia ser absorvida e assimilada pelos autores, e também pelos espectadores.

Por trás dos elogios ao teatro realista de Alexandre Dumas Filho, e sua versão moralista da comédia de Molière, Alencar opõe o teatro dos que no Brasil seguiram o gosto da "chusma”, e assim produziram obra que no seu entender não era "elevada", como seria desejável ao seu propósito de atender às consciências "ilustradas”, de criar a verdadeira comédia. A finalidade da comédia assim criada (e do drama também, como se verá pela prática dos autores realistas franceses e do próprio Alencar, na análise das peças) será a de traçar um "daguerreótipo moral” da sociedade. $^{29}$

As comédias realistas de Alexandre Dumas Filho e Emile Augier apresentavam-se como modelos máximos dessa escola, já que aliavam as lições moralizantes ao encadeamento rigoroso retirado das técnicas de carpintaria teatral desenvolvidas por Eugéne Scribe. ${ }^{30}$ Na França, o romancista e iniciador do movimento naturalista no teatro, Èmile Zola, questionava intensamente os métodos da peça bem-feita, apresentando caminhos para a dramaturgia opostos àqueles realizados pelos seguidores das técnicas de boa carpintaria teatral. Como exemplo, para explicar a falta de importância concedida por ele à engrenagem dramática perfeita, o dramaturgo utilizou em seu tratado sobre o

\footnotetext{
${ }^{29}$ Flávio Aguiar, A comédia nacional no teatro de José de Alencar. São Paulo, Editora Ática, 1984, p.39

${ }^{30}$ O dramaturgo Eugéne Scribe escreveu perto de quinhentas peças para consumo imediato. Iniciou a sua carreira com a composição de um vaudeville em um ato e a partir de então produziu quase todo o gênero de peças - comédias, tragédias, vaudevilles e libretos. Victorien Sardou, quarenta anos mais jovem, foi seu herdeiro e da mesma forma que o mestre experimentou tudo o que ia ao encontro do gosto do público da época, sem interesse em aprofundar-se na criação de personagens ou em problemas gerais.
} 
naturalismo no teatro, a reação de um crítico ao espetáculo $O$ filho natural, de Alexandre Dumas Filho:

De repente um crítico salta de entusiasmo. E ei-lo que parte. Meu Deus! Que peça bem construída! Como está aplainado, encaixado, colado, cavilhado! Que mecanismo maravilhoso! E este aqui se apresenta bem a ponto para ser engrenado nesta outra peça, que ela própria põe em movimento toda a máquina! Então, ele se pasma, não acha palavras bastante elogiosas para traduzir o prazer que sente diante desta mecânica. (...) Eu, eu permaneço frio diante de O filho natural. Por quê? Sou mais tolo que o crítico? Não acho. Só que não tenho gosto pela relojoaria e tenho muito mais gosto pela verdade. Sim, com efeito, é um lindo mecanismo. Mas quereria a vida, com seu estremecimento, com sua amplidão, com seu vigor, quereria toda a vida. ${ }^{31}$

Zola criticava, dessa maneira, a maquinaria do drama, que apresentava a vida poupada de suas cruezas. A lógica de encadeamento linear presente nas comédias realistas francesas implicava em um único desdobramento para os acontecimentos. Os autores, segundo Zola, acabavam por manipular as peripécias com tal maestria que os espectadores enxergavam como verdadeiras situações teatralmente armadas. Para um dramaturgo como Zola, as engrenagens dramáticas, que apareciam como ingredientes de sucesso absoluto no teatro francês, durante toda a segunda metade do século XIX, eram antes um vício que uma virtude.

No Brasil, Dumas e Augier, conhecidos entre os escritores brasileiros através das temporadas do Ginásio Dramático, passaram a representar modelos para a criação de uma dramaturgia nacional. José de Alencar, Joaquim Manuel de Macedo e, a partir dos anos 1860, outros tantos escritores, lançaram-se na tarefa de construir peças inspiradas nos preceitos desta escola. Defendia-se uma comédia que atraísse a elite para os teatros, que se dirigisse às senhoras de família e às moças novas, futuras mães e esposas fornecendo-lhes exemplos de conduta. Desta forma, estas comédias mantinham-se restritas ao âmbito privado, tratando dos dilemas desta burguesia ascendente e dentro dos limites do drama.

Trata-se da chamada "alta comédia" ou, para usar o conceito mais preciso de Luckács, da comédia dramática - o verdadeiro ideal de nossa intelectualidade oitocentista, que desejava

\footnotetext{
${ }^{31}$ Émile Zola, O romance experimental e o naturalismo no teatro. São Paulo, Perspectiva, 1982, p.136.
} 
introduzir no Brasil um importante melhoramento da vida moderna francesa: o teatro burguês em suas duas vertentes, o drama - ideal máximo com o qual todos, sem exceção, sonharam - e sua versão bem humorada (final feliz), por assim dizer mais leve, que é a "alta comédia”. 32

Diferentemente das comédias de Martins Pena - que eram consideradas farsas e sem a pureza da "alta comédia”, já que colocavam em cena além de senhores de escravos e juízes, os próprios escravos e problemas oriundos deste "mundo do trabalho" -, as comédias aclamadas pela crítica de meados do século XIX, como as de Alencar e Macedo, seguiam claramente os ensinamentos da escola francesa, retratando os problemas íntimos da classe média que se formava na sociedade brasileira.

As comédias do Trianon, representadas com grande sucesso nos anos 1920, apareciam orientadas no mesmo sentido que as "altas comédias" do século XIX. Semelhança que não simplifica o nosso trabalho de vislumbre de um horizonte estético preponderante no teatro brasileiro em início do século XX - já que o gênero Trianon possui as suas particularidades, apresentando resoluções formais próprias e por vezes distintas das comédias realistas do século anterior -, mas que possibilita o estabelecimento de um diálogo entre as obras produzidas nos dois períodos, colocando em tensão estes projetos estéticos, além de abrir possíveis relações entre os contextos históricos em que estavam inseridos.

A comédia, tal como se configurava no "elegante teatro da Avenida”33, mesmo produzida a partir de uma realidade social diversa, encaixava-se nos limites da "alta comédia”, pois atendia às exigências da estrutura dramática da peça bem-feita, buscava permanecer no ambiente familiar, obedecer aos princípios de decoro, defender de forma irreparável os valores da burguesia, tais como o casamento e a manutenção da família, e, finalmente, atender ao gosto da "boa sociedade". Quando os autores encenados no teatro Trianon se desviavam das condições estabelecidas, quando abriam mão das regras pertinentes à “alta comédia”, eram logo reprimidos pelos críticos da época, tal como se vê na crítica não assinada à peça $A$ casa do tio Pedro, de Oduvaldo Vianna, publicada no Jornal do Commércio no ano de 1920:

\footnotetext{
${ }^{32}$ Iná Camargo Costa, obra citada, 1998, p.127.

33 Jornal do Commércio, 29/03/1915, apud Adriano de Assis Ferreira, obra citada, p 119.
} 
As réplicas desses personagens tornam-se, às vezes, demasiado pesadas, cínicas até; e convinha realmente suprimir alguns ditos mais próprios de revista de ano que de uma comédia de costumes, escrita para um teatro freqüentado por gente distinta e de bom gosto. ${ }^{34}$

Enquanto os espetáculos de revista utilizavam-se de efeitos circenses, de linguagem exagerada, de cenas apoteóticas, as comédias do Trianon buscavam uma linguagem mais realista, respeitavam as regras de linearidade e causalidade da trama e traziam personagens tirados do cotidiano, figuras encontradas entre as famílias de classe média. Seguindo a receita dos autores franceses do século XIX, os escritores brasileiros eram aclamados como mestres da carpintaria teatral, possuidores de uma técnica perfeita:

Não vejo em nenhum autor brasileiro observações mais exatas, mais habilidade no mover dos personagens, nem mais brilho e naturalidade nos diálogos. As cenas são tão bem entrosadas que as situações surgem sem esforço, preparadas pela mão de mestre. ${ }^{35}$

O encadeamento dramático rigoroso passou a ser parâmetro de análise utilizado para medir o valor das peças produzidas. As comédias, quando conseguiam apresentar uma estrutura dramática bem amarrada, eram descritas como merecedoras de todos os méritos. Flores de Sombra, de Cláudio de Souza, foi aclamada como obra "teatral e literariamente bem-feita, com movimento, verdade, graça e boa linguagem”. ${ }^{36}$ A satisfação dos espectadores, aliada a uma espécie de teatro que se diferenciava dos espetáculos musicados, sem interrupções através de quadros isolados, causava grande euforia entre os críticos teatrais do período, que, com a estréia dessa peça, comemoraram a criação de um teatro verdadeiramente nacional e "digno da nossa cultura". ${ }^{37}$

Ao adotar uma visão mais comportada e mais condizente com a platéia familiar, afastando-se da linguagem “chula” dos picadeiros, as comédias representadas no Trianon, à semelhança das comédias realistas presentes no Brasil no tempo do Ginásio Dramático, incorporavam e divulgavam a forma e os princípios próprios ao drama.

\footnotetext{
${ }^{34}$ Idem, p.266.

${ }^{35}$ Goulart de Andrade, “Algumas opiniões sobre Flores de sombra”. In: Cláudio de Souza. Flores de Sombra. Rio de Janeiro, Typ. Fluminense, 1922, p.III.

${ }^{36}$ Amadeu Amaral, “Algumas opiniões sobre Flores de sombra”. In: Cláudio de Souza, obra citada, p.IV.

${ }^{37}$ João Luso, “Algumas opiniões sobre Flores de sombra”. In: Cláudio de Souza, obra citada, p.III.
} 
Além disso, se na França do século XIX os dramaturgos conseguiam angariar um bom lucro, transformando o teatro em bom negócio empresarial - "Scribe se transformou numa verdadeira fábrica, pagando royalties pelas idéias de outros homens; a esse paradigma de eficiência da classe média, o teatro era um negócio e ele o tornou lucrativo”38 -, no Brasil, nas primeiras décadas do século XX, procurando, ainda que tardiamente, reforçar os fundamentos da burguesia, as comédias apresentadas no teatro Trianon também passaram a significar garantia de bom negócio, gerando rios de dinheiro para os seus empresários.

O Trianon era a menina dos olhos de quantos militavam no teatro. Todos o ambicionavam. Os atores, para fazer nome, e os empresários, para enriquecer. Ali tinham feito fortuna Cristiano de Souza, Alexandre de Azevedo, Leopoldo Fróes e Antonio Serra. O Trianon era uma mina inexaurível. Bastava abrir a porta e deixar o público entrar. ${ }^{39}$

Mesmo se dirigindo a uma platéia "mais refinada”, os espetáculos do Trianon recebiam um público mais heterogêneo que aquele que freqüentava o Ginásio Dramático. Os espectadores que concorriam aos espetáculos nesse período eram "membros das novas classes médias urbanas (de estudantes a comerciantes e funcionários) e membros das camadas mais populares da República Velha”. ${ }^{40}$ Os temas predominantes tratavam do universo íntimo de uma família tipicamente burguesa; questões ligadas ao casamento, ao ambiente familiar e também ao dinheiro, eram as preferidas.

A conquista do público não se dava sem que os autores precisassem construir narrativas correspondentes aos seus anseios, peças que espelhassem e, ao mesmo tempo, fortalecessem seus valores. O riso e o agrado do público, constituído por novos "personagens" que se aglomeravam nos centros urbanos remodelados, eram o objetivo principal e acabavam por marcar de maneira decisiva a dramaturgia produzida. Como vimos, era comum aparecer a descrição dessas comédias como "peças leves, sem grandes pretensões estéticas e feitas somente para rir”, porém não se pode dizer que a vontade de agradar o público a todo custo não fosse outra coisa que não uma pretensão estética. Outros

\footnotetext{
${ }^{38}$ John Gassner, Mestres do Teatro I. São Paulo, Perspectiva, 1974, p. 402

${ }^{39}$ Procópio Ferreira. Procópio Ferreira apresenta Procópio. Rio de Janeiro, Rocco, 2000, p.74.

${ }^{40}$ Beti Rabetti, Teatro e comicidades 2: modos de produção do teatro ligeiro carioca. Rio de Janeiro, 7letras, 2007, p.39.
} 
traços que podem ser destacados dessas produções relacionam-se tanto à feitura em série de comédias, quanto às exigências feitas pelos atores-empresários que encomendavam textos promissores de grande bilheteria e geradores de boa receita:

Os autores recorrem às técnicas de sucessivos ajustes de sua própria obra mediante limites do palco, do ator, do empresário e do público, procedendo a adaptações, a sínteses e atualizações de repertórios tradicionais dramatúrgicos. São técnicas exigentes, no entanto, de inventivas habilidades e agilidades para a sobrevivência no mundo da diversão. ${ }^{41}$

A entrada do teatro no processo de montagem da indústria cultural exigia que a cena se adequasse a um modelo de venda. A fragilidade das companhias teatrais, que se desmanchavam com a mesma freqüência que se formavam, e as exigências do ator-estrela muitas vezes dono da companhia que encomendava o texto -, representavam os "limites do palco” enfrentados pelos autores e, também, pelos demais artistas. O que se nota nesse período é que o teatro carioca começou a fazer parte da vida da cidade como nunca havia acontecido antes.

Se aspectos como esses podem ser compreendidos como um modo de produção diferenciado no teatro brasileiro, marcado especialmente pela importante popularização dessa arte entre nós, podem também nos levar de volta aos preceitos do realismo teatral francês, apontados anteriormente como modelo para a construção do teatro nacional nos anos de 1850 a 1860. A necessidade de agradar o público a todo custo, para que ele comparecesse ao teatro e ali encontrasse tramas que jamais se mostrassem perturbadoras da ordem estabelecida, assemelha-se justamente às opções dramáticas que se estabelecem na peça bem-feita, às quais o drama moderno se contrapõe formalmente. O jogo de cena e a defesa do conceito de naturalidade, próprios do realismo teatral francês, aplicados tanto ao espetáculo quanto ao texto dramático, podem bem ser aproximados dessa necessidade imperiosa de conquistar o público através de histórias que correspondam aos seus anseios imediatos.

A aproximação do teatro e do público, no caso específico da cena brasileira à época do Teatro Trianon, com intensificação das atividades teatrais e grande afluência de

\footnotetext{
${ }^{41}$ Beti Rabetti, obra citada, p.57.
} 
espectadores, principalmente na cidade do Rio de Janeiro, se dava via facilitação do diálogo, através de uma dramaturgia que era construída para corresponder a um pretenso gosto. O teor moderno de algumas inovações cênicas européias que chegavam por aqui, marcadas pela intensificação de diálogo entre obra e espectador, em que o autor não procura mais "embalar e adormecer a sua miséria e o seu labor, mas, pelo contrário, estimular seu esforço”42 - utilizando as palavras do encenador francês André Antoine, proferidas em palestra no Teatro Lírico, no Rio de Janeiro, cerca de duas décadas antes -, via-se aclimatado e transformado em diálogo acentuado não pela contundência do mesmo, mas por um sabor adocicado.

Quando, no início do século XX, apareceram nos jornais as críticas aos espetáculos naturalistas trazidos ao Rio de Janeiro pela companhia de Antoine, ficava claro que a aclimatação do repertório europeu para que obtivesse sucesso de crítica e público, estava também vinculada ao afastamento de, em primeiro lugar, questões complexas e com forte teor reflexivo, e, em segundo, temas que fossem considerados demasiadamente tristes.

Ou seja, se, nas críticas ao repertório naturalista apresentado por aqui no início do século XX, defendia-se que o teatro devia divertir e aliviar os momentos de seriedade e tensão próprios da vida, não era de se estranhar que a mesma prerrogativa fosse incorporada no estabelecimento de nossa comédia dramática. A comédia, tal como se configurou nos palcos do Trianon, juntava em suas características a necessidade imperiosa de fazer rir, sem com isso abrir mão de atingir os preceitos da peça bem-feita: uma história linear, que não recorre a efeitos do "baixo cômico" e que apresenta a família e a necessidade de manutenção de sua força como centro da trama. O uso das regras da peça bem-feita incorporadas à comédia de costumes adaptava-se em grande medida à situação histórico-social do Brasil do começo do século XX.

\section{Engrenagem dramática imperfeita nas comédias de Martins Pena.}

Outro aspecto a ser levado em conta na aproximação entre o projeto estético de criação de um drama burguês no Brasil, em versão cômica, refere-se às diferenças apontadas entre as comédias do Gênero Trianon e as comédias de costumes de Martins Pena.

\footnotetext{
${ }^{42}$ André Antoine, Conversas sobre encenação. Rio de Janeiro, 7Letras, 2001, p. 48.
} 
Pena apresentava em suas peças problemas cruciais da sociedade em meados do século XIX. Já em seus primeiros textos notamos descrições minuciosas dos principais tipos brasileiros, como os senhores de escravos e os escravos. O comportamento de um e outro aparece marcado pela realidade histórica do país:

Sua inovação mais importante foi ter introduzido, na organização simétrica da comédia, a assimetria básica da figura do escravo. O lugar deste personagem cria realmente uma situação teatral nova, longe da tradição que o associava ao simples palhaço. ${ }^{43}$

Observamos também nas peças de Pena, além do retrato da violência nas relações sociais, apontado pela condição escravocrata do país, a facilidade com que a justiça via-se corrompida em situações diversas e o predomínio do interesse privado em detrimento daquilo que representava o interesse público. Na peça Os dous ou O inglês maquinista, que se passa no Rio de Janeiro, no ano de 1842, a senhora Clemência, em conversa com um traficante de escravos, se vangloria do fato de ter conseguido um meia-cara, ou seja, um negro africano recém chegado de seu país e que por lei, aprovada onze anos antes, deveria ser considerado liberto:

Clemência - Deixe-o falar. A propósito, já lhe mostrei o meu meia-cara que recebi ontem na Casa da Correção?

Negreiro - Pois recebeu um?

Clemência - Recebi, sim. Empenhei-me com minha comadre, minha comadre empenhou-se com a mulher do desembargador, a mulher do desembargador pediu ao marido, este pediu a um deputado, o deputado ao ministro e fui servida.

Negreiro - Oh, oh, chama-se isto transação! Oh, oh! Clemência - Seja lá o que for; agora que tenho em casa, ninguém mo arrancará. Morrendo-me algum outro escravo, digo que foi ele.

Felício - E minha tia precisava deste escravo, tendo já tantos?

Clemência - Tantos? Quanto mais, melhor. Ainda eu tomei um só. E os que tomam aos vinte e aos trinta? Deixa-te disso, rapaz. Venha vê-lo, Sr. Negreiro. (Saem). ${ }^{44}$

\footnotetext{
${ }^{43}$ Vilma Áreas, Martins Pena: comédias. São Paulo, Martins Fontes, 2007, p.XXIII.

${ }^{44}$ Martins Pena. Comédias. São Paulo, Martins Fontes, 2007, p.148.
} 
Através de uma rede engenhosa de conhecimentos, alguns componentes da sociedade faziam com que seus interesses prevalecessem sobre os interesses dos demais. Aquilo que devia ser trivial entre os donos de escravos, o autor recorta e aponta como estranhável. Nesse endurecimento de personalidade, que demonstra descaso para com a esfera coletiva, nessa “falta” da personagem Clemência, sublinhada pelo autor, surge a crítica à sociedade e ao modo como as leis eram aplicadas no país.

Alguns escritores do século XIX, tais como Alencar e Machado, argumentavam que as peças de Pena ainda não apresentavam o amadurecimento necessário para que fosse considerada modelo de comédia nacional, eram "antes uma sátira dialogada do que uma comédia" ${ }^{\text {45 }}$ e prendiam-se intimamente às tradições da farsa portuguesa. O caráter de sátira e de farsa detectado nas peças sugeria que a engrenagem dramática da "alta comédia” não aparecia com perfeição nas comédias de Pena - e nem poderia, pois a cada espaço aberto pelo autor para uma crítica aos fundamentos da sociedade, como aquela citada acima, mais difícil se tornava manter o motor dramático funcionando sem que a presença do autor ficasse clara. Existiam cenas que poderiam não estar ali, que pareciam soltas. Suas comédias eram criticadas, pois não haviam incorporado os ensinamentos de uma comédia mais hábil, ou seja, de uma comédia bem-feita.

Nas peças do Trianon este "defeito" encontrado nas peças de Pena parece aos poucos diminuir. Cada vez mais os autores compreendem a estrutura dramática rigorosa, ideal do drama burguês, que, obedecendo a uma lógica causal, supostamente natural, apresenta uma trama em que cada cena parece brotar da anterior, sem lacunas desnecessárias. “O drama é absoluto. Para ser relação pura, isto é, dramática, ele deve ser desligado de tudo que lhe é externo. Ele não conhece nada além de si”. ${ }^{46}$ Este rigor dramático se viu fortemente criticado pelos artistas e teóricos modernos por constituir uma história determinista, como que imutável, sem espaço para interferências.

Nas comédias do Trianon, o autor, o âmbito coletivo e os problemas externos tendem a desaparecer. Os criados aparecem, mas não os seus dilemas; eles não são mais escravos, porém a sua figura não possui representatividade, os seus problemas não interessam. Quando um escravo aparece na comédia de Pena sendo presenteado a alguém

\footnotetext{
${ }^{45}$ José de Alencar, apud João Roberto Faria, obra citada, 2001, p.470.

${ }^{46}$ Peter Szondi, Teoria do drama moderno. São Paulo, Cosac e Naify, 2001, p.30.
} 
dentro de um cesto, a temática da peça escapa da vida privada e aponta para a vida pública, mesmo que a cena se passe em uma sala de visitas. A presença dos empregados nas tramas das comédias do Trianon, ao contrário, não aponta para a vida pública. Os criados estão ali para que o retrato da família brasileira fique completo. A crítica à sociedade é colocada sob o ponto de vista de uma classe determinada. Denunciam-se os maus burgueses, a ganância, a falta de escrúpulos e o interesse voltado para o dinheiro, mas não interessa discutir questões do "mundo dos criados”. A caracterização da família brasileira ocorre sem que sejamos convidados a refletir acerca de questões de âmbito coletivo, desconsiderando aspectos sociais marcantes, que condicionam os gestos e comportamentos no âmbito da vida privada.

Num período tumultuado para a vida nacional, quando o país se debatia com movimentos revolucionários periódicos, perseguições políticas, etc., causa estranheza, hoje em dia, a alienação total desse pequeno teatro dominante, em que somente o texto de revista oferecia certa atualidade, através da sátira política bem acentuada. ${ }^{47}$

As comédias do Trianon compartilhavam procedimentos da comédia de costumes e do teatro ligeiro; aspectos de uma e outra estética aclimatados que se configuravam, em forma e conteúdo, muito próximos da estrutura da peça bem-feita. Nesse meio do caminho, abrandando o caráter crítico de estudo da sociedade e adotando o princípio do teatro como diversão, compunha a sua verdadeira feição: o nosso drama burguês em chave cômica.

A maneira pela qual é comunicado o mundo imaginário pressupõe certa atitude em face deste mundo ou, contrariamente, a atitude exprime-se em certa maneira de comunicar. Nos gêneros manifestam-se, sem dúvida, tipos diversos de imaginação e de atitudes em face do mundo. ${ }^{48}$

Ao se tornarem representantes da versão bem humorada do drama burguês, essas comédias podem ser observadas para além do mero caráter de "teatro leve, sem pretensões, feito exclusivamente para rir”. ${ }^{49}$ Talvez seja preciso retirar a prerrogativa de ingenuidade que acompanha essas produções e analisá-las tendo em vista sua atitude em face do mundo,

\footnotetext{
${ }^{47}$ Gustavo Dória, Moderno teatro brasileiro. Rio de Janeiro, Serviço Nacional de Teatro, 1975, p.21.

${ }^{48}$ Anatol Rosenfeld, O teatro épico. São Paulo, Perspectiva, 1985, p.17.

${ }^{49}$ Brício de Abreu. apud Edwaldo Cafezeiro e Carmem Gadelha, obra citada, p.441.
} 
o diálogo que propunham com a sociedade, diálogo exposto tanto no conteúdo de suas tramas quanto nas formas dramáticas adotadas.

\section{Flores de sombra e Onde canta o sabiá.}

Flores de sombra, de Cláudio de Souza e Onde canta o sabiá, de Gastão Tojeiro, duas peças que obtiveram extremo sucesso de público e crítica, foram consagradas como inauguradoras do chamado gênero Trianon de comédias. Flores de sombra estreou em São Paulo e seguiu para o Rio de Janeiro para uma carreira de 108 representações consecutivas; Onde canta o sabiá estreou no Rio de Janeiro e obteve também longa temporada nessa cidade. Os sucessos de público, com espetáculos representados mais de cem vezes consecutivas, não eram comuns na realidade teatral brasileira e marcaram decisivamente a trajetória do Trianon.

Como características fundamentais estas peças possuem o respeito à forma dramática tradicional, a permanência no âmbito da vida privada, a defesa da família, do casamento e de valores relativos ao mundo burguês. Além disso, ambas buscavam demonstrar modelos de comportamento para as moças, futuras mães e esposas, os quais apontavam para a necessidade de que as mulheres não se deixassem levar pelas armadilhas dos tempos modernos.

Em Flores de sombra, os valores familiares tradicionais estão representados pela fazenda, espaço idealizado como símbolo de segurança e felicidade, em contraposição ao ambiente da capital, promotor de experiências fugidias e encorajador do desapego a esses valores. No primeiro ato, conhecemos, além da mãe, D.Cristina - que, em uma fazenda no interior de São Paulo, aguarda ansiosamente a volta para casa do filho, Henrique -, os criados, o coronel, amigo da família e pai de Rosinha, moça que freqüenta a casa desde a infância e é considerada a esposa perfeita para o rapaz que está voltando para casa. O conflito se estabelece antes mesmo da chegada de Henrique, quando este anuncia por carta que pretende levar uma moça para apresentar à família. Na sequência, o conflito se acentua, pois com a chegada do filho fica claro o desagrado que tem pelas coisas do campo, pelos hábitos rurais que considera pouco civilizados. O rapaz, influenciado pelo amigo de infância Oswaldo, resolve transformar o velho casarão, trocando os móveis velhos por novos e escondendo todos os objetos que caracterizavam a velha fazenda. Para o desgosto 
da mãe, a sala de visitas da fazenda se transforma numa sala de visitas da capital, o lugar vira um cenário metropolitano, com móveis estofados, cortinas e outros enfeites, tudo para que as visitas possam sentir-se à vontade.

Toda a trama se passa na sala de visitas desta fazenda no interior de São Paulo. Os móveis e outros objetos de cena, tais como "uma rede armada a um canto", tornam o espaço reconhecível, como um ambiente familiar que tende a ser desmontado com a chegada do filho. O cenário que no drama "desaparece no palco, tornando-se ambiente"50 surge nesta comédia respeitando o mesmo princípio dramático. A teatralidade, pois, não está assumida, como seria próprio a uma opção cênica moderna. Mesmo a arrumação posterior que faz Henrique da sala de visitas aponta para os princípios dramáticos, que tentam criar para o espectador a ilusão de estar diante da própria vida.

No segundo ato, a sala de visitas não possui mais os mesmos móveis, mas um “mobiliário moderno”. Neste momento da trama, aparece Cecília, moça que vem da capital com Henrique, mas que não admira o jeito trabalhador do pretendente, mostrando-se entediada com o futuro noivo e deslumbrada por outro tipo, Oswaldo, o amigo de infância de Henrique, que tira graça de tudo e todos. O ridículo deste personagem fica patente com o encantamento perante tudo que não é brasileiro. A última cena deste ato apresenta esse arremedo de europeização levado ao extremo: Oswaldo propõe, para espantar o tédio, a execução, nos moldes franceses, de uma caça à raposa, porém, como não possuem raposa, contentam-se em caçar o gato preto do local.

O terceiro ato é a transformação, ou melhor, a volta à normalidade de Henrique, que readquire a postura respeitadora perante os costumes da casa, da família e da tradição. Como prova disso o rapaz pede a mão de Rosinha, a namorada de infância, e a peça termina com dois casamentos, o dos patrões e o dos criados, Adelaide e Possidônio.

O mecanismo dramático, as regras de linearidade e causalidade aparecem executadas fielmente no decorrer da trama. Como notaram os críticos da época, nada ocorre por acaso, o diálogo apresenta-se como motor do drama, as situações são encadeadas, o desenvolvimento dos acontecimentos é determinado pelas exigências internas da ação apresentada e as transformações ocorrem de maneira sutil. A mudança de atitude de Henrique, ao reconhecer o engano que estava cometendo ao desprezar os hábitos da família

\footnotetext{
${ }^{50}$ Anatol Rosenfeld, O teatro épico. São Paulo, Perspectiva, 1985, p.30.
} 
e tudo mais que representava o seu passado, não ocorre de maneira brusca, mas é lentamente preparada. Toda a peça se passa para que essa transformação ocorra.

Em sua conversa final com Adelaide, o rapaz descreve o asfalto das cidades, que não deixa rastros, enquanto a criada fala dos olhos do campo que vêem sempre a mesma paisagem, as mesmas árvores, o mesmo terreiro, os mesmos caminhos. A efemeridade da cidade se opõe à permanência da vida no campo. Outras oposições surgem enfatizando as diferenças entre um espaço e outro, as flores de sombra são comparadas com as moças do campo, e as flores de estufa representam as moças da cidade, o ambiente interno e o mundo externo, o calor do espaço familiar e a frieza do espaço público. A resolução final da peça aponta para uma escolha que parece inevitável: a "doçura do lar”. A escolha do rapaz de manter-se junto à sua família significa também a atenção voltada para o mundo privado, valorizando a dimensão íntima da ação, em detrimento de uma abordagem histórico-social dos fatos.

Henrique - Minha ambição, meu sonho, são a ambição e o sonho de toda a gente, a ambição e o sonho da felicidade, e só aqui eu posso encontrá-la, ao lado do meu sangue, na nossa casa (aponta o retrato do pai) à sombra daquela saudade. ${ }^{51}$

O lar é o centro do mundo burguês, portanto os seus atributos, assim como os da família e do casamento, são, diversas vezes, evocados nesta peça. A autoridade da mulher dentro do lar, outra imagem cara à burguesia em ascendência, aparece na figura da mãe de Henrique. “O espaço da felicidade, a casa, é o império onde reina a doçura da mulher”. 52 Na peça de Cláudio de Souza, a fazenda é o império de Dona Cristina - ela se mostra capaz de adivinhar o que está escrito na carta recebida pelo filho -, personagem que, assemelhando-se a um raisonneur do drama realista, demonstra sabedoria, possui uma consciência maior que a das outras personagens. Tudo que parecia obscuro para os outros à sua volta para ela já estava claro. No conjunto familiar burguês, se a figura paterna é a autoridade fora de casa, a figura materna exerce a mesma autoridade, só que dentro do lar.

O espaço familiar que havia sido desprezado pelo filho representa não somente a sua casa, mas os seus valores, a sua terra natal, provida de atributos indispensáveis, tais

\footnotetext{
${ }^{51}$ Cláudio de Souza, Flores de Sombra. Rio de Janeiro, Typ. Fluminenese, 1922, p.141.

${ }^{52}$ Hans Robert Jauss, Pour une esthétique de la reception. Paris, Gallimard, 1978, p. 273.
} 
como o calor e a segurança. Do outro lado, na vida da cidade, aparecem hostilidade, frieza e abandono. Como exemplo surge a experiência de Possidônio, o empregado da casa que tenta mudar de vida na capital, mas volta desiludido.

Henrique - Como você se arranjou na cidade?

Possidônio - Fiz como seu Oswaldo. Com o dinheirinho que levava comecei a convidar toda a gente para beber, e espichava a perna, e falava grosso com aquele entusiasmo com que ele fala...

Adelaide - (Aparte) Sem vergonha! O dinheiro que era para o nosso casamento!

D. Cristina - Enquanto teve dinheiro todo mundo foi seu amigo.

Possidônio - Sim, senhora. Depois que acabou o dinheiro - era tão pouco! - ninguém quis saber de $\operatorname{mim} !^{53}$

A cena citada, que mostra o retorno de Possidônio, arrependido de ter abandonado os seus afazeres e a fazenda de seus patrões, é construída de maneira leve, buscando a graça na figura do criado - o personagem volta para a fazenda usando um monóculo -, mas isso não significa que apareça isenta de imagens e exemplos de normas de conduta. A cena aponta, de maneira direta ou indireta, para a ameaça de punição que a escolha por uma vida desenraizada, longe dos olhos dos patrões, poderia significar.

Algumas questões externas, referentes ao mundo lá fora, aparecem na trama através das figuras de Oswaldo e Cecília; no entanto, são tratadas de maneira a perderem o seu teor crítico. É o caso do alistamento de eleitores executado pelo coronel, amigo da família, e a discussão acerca de como os casamentos são "arranjados” nesta sociedade. Oswaldo, ao escutar a combinação do coronel com o empregado que deve votar segundo as indicações do seu "padrinho", que por sua vez ajeitou os nomes dos candidatos com nomes de legumes e frutas, dispara:

Oswaldo (Aparte) - É padrinho da cidade inteira! (para o coronel) - Admirável instituição o voto popular, coronel. Os senhores acabam por transformar este país numa horta. Presidente, abóbora; vice-presidente, mamão; ministros, pepinos; senadores, chuchus; deputados, rabanetes. É épico ! ${ }^{54}$

\footnotetext{
${ }^{53}$ Cláudio de Souza, obra citada, p. 145.

${ }^{54}$ Idem, p.82.
} 
Naquilo que Dona Cristina, na cena anterior, não havia encontrado nada de anormal, Oswaldo consegue enxergar um problema. Neste exato momento ele aponta para o mundo externo, para a coletividade, para o poder dos coronéis e para a situação do país. Cecília, por sua vez, aponta para fora da esfera íntima da vida burguesa quando destaca a fragilidade das relações familiares, ao discutir com a sua mãe sobre o que significa um bom casamento:

Cecília - Que são, então, os casamentos da sociedade? São combinações de interesse, nas quais o amor não entra por nada. Ninguém se preocupou em saber quando Henrique nos foi apresentado se eu viria a amá-lo. Ainda é honesta a sedução quando é um só o bom partido que se oferece. Às vezes, são três ou quatro que freqüentam, ao mesmo tempo, a casa, e todos os três ou quatro são agradados. Deve-se amar, definitivamente, o que primeiro fizer o pedido. É o que se chama verdadeiro amor, o amor desinteressado. ${ }^{55}$

Porém, a força de alusão ao mundo externo se esvazia. Nos dois exemplos, os personagens que apresentam estes discursos, segundo a trama, são figuras sem juízo, que não devem ser levadas a sério. Diferentemente dos “heróis” das comédias realistas, estes personagens contrariam os valores supremos da burguesia: debocham da ligação familiar, desconfiam do casamento e desprezam o trabalho. Oswaldo e Cecília apontam para fora, para questões de ordem coletiva, mas as questões merecem pouco crédito devido à postura dos personagens. Enquanto as questões da vida privada ocupam o primeiro plano da cena, as da vida pública aparecem timidamente, de forma a se tornarem triviais - como é o caso da fraude nas eleições apontada por Oswaldo -, ou desacreditadas, sem promover mudanças nas atitudes ou transformar os conflitos internos - como é o caso do casamento, na fala de Cecília. A intenção parece ser a de tratar sem espanto o que de fato devia espantar; o arranjo que faz o coronel para a eleição, ou mesmo o casamento de Henrique com Rosinha são tratados como fatos consumados, como se não merecessem crítica, nem fossem passíveis de mudança.

Ao perder a intenção crítica na abordagem do tema, deixa-se de lado também a subversão da forma. A referência à eleição que está acontecendo do lado de fora ocorre de maneira tão tênue que não chega a ferir o princípio dramático adotado pela comédia.

\footnotetext{
${ }^{55}$ Idem, p.93.
} 
“Qualquer episódio que não brotasse do evolver da ação revelaria a montagem exteriormente superposta”. ${ }^{56}$ Assim, sem perder o evolver interno da ação dramática, em sua dimensão intersubjetiva, as referências ao âmbito coletivo são rapidamente esquecidas e logo o foco da trama volta-se para o ambiente privado, de problemas pessoais.

A estrutura da peça bem-feita, da qual estamos aproximando as comédias aqui analisadas, prevê tramas elaboradas, cuidadosamente maquinadas e limpidamente resolvidas, nas quais a intriga progride de forma tão uniforme que não deixa espaços para questionamentos ou ponderações.

Cartas eram introduzidas e descobertas no momento apropriado, o suspense era mantido a qualquer custo e na conclusão da peça uniam-se todos os fios, não ficando nada que a inteligência fosse obrigada a examinar ou a ponderar. ${ }^{57}$

As questões levantadas pelos dois personagens vêem-se perdidas no meio desta engrenagem. As brechas encontradas na trama de Flores de sombra - eleitores fantasmas, o voto de cabresto, a situação da mulher no casamento - não chegam a se configurar como espaços de ponderação. Como vimos, essas questões aparecem de maneira sutil, são lances que nos levam para fora do eixo principal, mas que rapidamente são enfraquecidas, seja pelo respeito à forma dramática, que nos lança de volta ao espaço intersubjetivo da ação, seja pela pouca credibilidade conferida aos personagens que levantam tais questões. Uma leitura atual do texto nos possibilita questionar em que medida a síntese da sociedade pretendida por estas comédias de costumes se tratava somente de um retrato despretensioso, ou se estava relacionado com um projeto constituído para a sociedade.

Do teatro íntimo ao grande teatro do mundo, do teatro de câmara ao teatro histórico, as mudanças de "formato", as origens das personagens, a organização da narrativa e a natureza da escrita correspondem a projetos dos autores, inevitavelmente atravessados pela história e pelas suas ideologias. ${ }^{58}$

\footnotetext{
${ }^{56}$ Anatol Rosenfeld, obra citada, 1985, p.33.

${ }^{57}$ Jonh Gassner, obra citada, 1974, p.402.

${ }^{58}$ Jean-Pierre Ryngaert, Introdução à Análise do Teatro. São Paulo, Martins Fontes, 1996, p. 9.
} 
Em Onde canta o sabiá, de Gastão Tojeiro, comédia em três atos representada no Trianon em 1921, de novo, como em Flores de Sombra, a temática se volta para as diferenças entre o espaço externo, estrangeiro, e o interno, nacional. Desta vez, a discussão se dá entre os encantos de Paris e a valorização da terra natal.

A trama acontece toda na sala de visitas de uma casa situada no subúrbio carioca; perto dali passa uma linha de trem por onde chegam as novidades, amigos e pretendentes. O clima da casa é pautado por situações típicas da família brasileira com a qual estas comédias intentam dialogar. A convivência difícil entre patrões e empregados, bem como as implicâncias entre os familiares - a mulher que briga com o marido, a sogra que briga com o genro, o primo que briga com os tios -, desenham esse ambiente que quer parecer reconhecível e agradável.

No final do primeiro ato, aparece Elvídio, rapaz que mora em Paris e veio para o Rio de Janeiro somente para vender suas propriedades, pois não suporta o Brasil. O conflito dramático, que aponta para vontades diversas e coloca os personagens diante do desejo de convencer e dissuadir uns aos outros ${ }^{59}$, se estabelece nesta comédia, especialmente, entre este personagem e a filha caçula da casa. O rapaz coloca em lados opostos mente sã e casamento, bem-estar e família, os ares sadios da Europa e o Brasil, “onde tudo é mau e insuportável”. ${ }^{60}$ Enquanto Nair, a filha caçula, ao contrário, pensa no Brasil como um lugar deslumbrante, admira os hábitos de sua terra e sente-se intimamente ferida quando alguém desmerece o próprio país com vistas a elogiar uma terra estrangeira.

A discussão entre as possíveis vantagens da França em relação ao Brasil, ou viceversa, contudo, não se efetiva, pois as preferências apontadas pelas personagens desenvolvem-se em esfera intersubjetiva. O tema poderia gerar uma abordagem de interesse coletivo acerca das dificuldades do país e também de viver no exterior, porém a comparação entre Brasil e França transforma-se em colocações meramente pessoais, uma questão de gosto, sem margens para discussões. A questão principal não é a diversidade entre os países, mas a diversidade entre os personagens; resolvida esta questão, tudo o mais se encontrará também resolvido.

\footnotetext{
${ }^{59}$ Anatol Rosenfeld, obra citada, 1985, p.34.

${ }^{60}$ Gastão Tojeiro, Onde canta o sabiá. Rio de Janeiro, SNT/MEC, 1973, p.24.
} 
No início do segundo ato, durante almoço na casa da família, Nair demonstra desprezo por Elvídio, que desdenha de sua terra natal; porém, no final deste ato, recebe uma declaração de amor do rapaz e a situação se modifica. No terceiro ato, passaram-se dez dias desde o último encontro, Nair mostra-se completamente apaixonada, mas triste e cabisbaixa, pois não é capaz de assumir os seus sentimentos, e Elvídio encontra-se já as vésperas de partir de volta para Paris. Nesta comédia, assim como em outras do mesmo período, notamos que entre um ato e outro ocorre quase sempre uma passagem de tempo. Através das falas dos personagens fica claro que se passaram alguns dias ou até uma semana inteira de um ato para o outro. Porém estes avanços no tempo, que poderiam estabelecer uma lógica espacial e temporal diversa do presente contínuo característico do drama, ou se configurarem como quebras narrativas, não chegam a interromper o fluxo linear da trama. Ao contrário, a passagem de tempo é quase imperceptível, tal a causalidade observada entre as cenas.

Sendo o drama sempre primário, sua época é sempre o presente. O que não indica absolutamente que é estático, senão somente que há um tipo particular de decurso temporal no drama: o presente passa e se torna passado, mas enquanto tal já não está mais presente em cena. Ele passa produzindo uma mudança, nascendo um novo presente de sua antítese. O decurso temporal do drama é uma seqüência de presentes absolutos. Como absoluto, o próprio drama é responsável por isso; ele funda o seu próprio tempo. (...) A partir disso a exigência dramatúrgica pela unidade de tempo é compreensível sob uma nova luz. ${ }^{61}$

Assim, nas peças analisadas o tempo avança entre um ato e outro, porém a continuidade rigorosa da ação não se perde. A unidade de tempo se reconfigura através da seqüência causal perfeita que ocorre entre as cenas. Cada cena é construída de forma a produzir a próxima. Desta maneira, a passagem de tempo, que poderia relativizar determinada cena construindo-lhe um passado específico, fica eliminada da consciência do espectador e a cena não se destaca do todo.

Outro aspecto marcante nas comédias representadas no Trianon, que possuem características próprias e que precisam ser levadas em conta quando analisadas em suas especificidades, diz respeito ao afastamento que mantêm, por vezes, em relação à definição

\footnotetext{
${ }^{61}$ Peter Szondi, obra citada, 2001, p.33.
} 
propriamente dita da comédia de costumes. Este tipo de comédia se define como "estudo do comportamento do homem em sociedade, das diferenças de classe, meio e caráter”,62; o seu “enfoque privilegia sempre um grupo, jamais um indivíduo, e é em geral de natureza crítica ou até mesmo satírica”. 63

Como vimos, as comédias de Martins Pena, criticadas pelos seus contemporâneos, abriam mão de seguir as regras de uma comédia bem-feita, mas com isso conseguiam ressaltar o ambiente histórico e manter-se fiel ao viés crítico da comédia de costumes. Já em uma comédia como Onde canta o sabiá, que se aproxima da estrutura dramática rigorosa, a dissidência crítica surge de maneira atenuada. Os hábitos familiares retratados não aparecem dispostos a serem criticados ou corrigidos. O riso é previsto e encontrado nas gagues, nos erros de português e repetições feitas, principalmente, pelos criados. A assimetria colocada por Pena na estrutura da comédia, quando em seus textos retira o escravo do papel de palhaço e transfere "a responsabilidade da ação cômica dos criados tradicionais para outros tipos de situações” ${ }^{64}$, parece esquecida nas comédias do Trianon, nas quais os personagens das classes populares tornam-se risíveis. O "estudo do homem em sociedade” parece resumir-se ao espelhamento dos conflitos da vida íntima dos patrões.

\section{Transmissão e legitimação de normas sociais através da cena.}

A comédia brasileira das primeiras décadas do século XX, arranjada sob a forma engenhosa da estrutura do drama, perdia as lacunas para ponderações e tornava-se um teatro repleto de lições moralizantes. Abordados em uma esfera íntima, os fatos vinham explicados, retirando do público a possibilidade de experiência crítica, além de esmaecer o papel autoral que poderia caber ao espectador. O discurso cênico moderno, que anunciava, entre tantos elementos inovadores, a quebra da estrutura rigorosa da peça bem-feita e a entrada de elementos contraditórios e nem sempre lineares da vida social, encontrava nesta comédia antes um freio que um estímulo.

A defesa da família, do casamento e o elogio da segurança do lar, aspectos que podem ser observados nestas peças, representavam opções estéticas, modelos de atitude

\footnotetext{
${ }^{62}$ Patrice Pavis, obra citada, Dicionário de teatro. São Paulo, Perspectiva, 2001, p.55.

63 J. Guinsburg; João Roberto Faria; Mariângela Alves de Lima (orgs.). Dicionário do teatro brasileiro: temas, formas e conceitos. São Paulo, Perspectiva, 2006, p.88.

${ }^{64}$ Vilma Areas, obra citada, 2007, p.XXIII.
} 
revelados e legitimados pela cena teatral. Pois, “o tema poético com suas variações é também um paradigma social que comunica sempre experiências, ensina modos de comportamento e normas de saber cotidiano". 65 Estas produções artísticas apresentavam respostas elaboradas por autores da época às perguntas do seu tempo. Ao observarmos este jogo de perguntas e respostas apresentado pela cena, notamos que a maneira pela qual a família brasileira era levada para o palco não espelhava somente uma realidade, mas também se esforçava para reforçar tal imagem. O conteúdo privado das questões apresentadas e o afastamento de questões de ordem pública também reforçavam valores e comportamentos. No lugar de pensarmos a obra que apenas retrata o que está à sua volta, podemos pensá-la em sua função comunicativa, na relação que a obra estabelece com os seus receptores, o grau de renovação ou de conformidade que apresenta com as regras de seu tempo, pois o "modo como a obra se apropria dos elementos do cotidiano e reelaboraos artisticamente indicia seus contatos com a sociedade". ${ }^{66}$

O casamento, como algo que devia ser valorizado e adaptado sempre que necessário para que a sua manutenção fosse possível, recebeu entre nós atenção especial. Assim como nas comédias que o tinham como tema predileto, as revistas e os suplementos literários especialmente elaborados para o público feminino concediam enorme importância ao assunto.

Com o crescimento das cidades e a variedade de experiências e linguagens que este crescimento representava para a população, era possível notar mudanças de comportamento, questionamento de hábitos e costumes há muito respeitados. Diante desta desestabilização, própria da vida moderna, o que se via entre nós era um esforço para a contenção dos questionamentos que surgiam; ou seja, era notável a quantidade de artigos produzidos tanto por homens quanto por mulheres em revistas e outros meios de comunicação que tinham como objetivo conter a suposta "corrosão da ordem social, a quebra de costumes e, principalmente, as modificações nas relações entre homens e mulheres”. ${ }^{67}$ Os papéis sociais que cabiam aos homens e às mulheres eram nitidamente definidos entre nós; ao homem cabia prover a casa, o sustento da esposa e filhos, e no caso

\footnotetext{
${ }^{65}$ Hans Robert Jauss, obra citada, 1978, p. 276.

${ }^{66}$ Regina Zilberman, obra citada, 1986, p.100.

${ }^{67}$ Maria Lúcia Mott e Marina Maluf, “Recônditos do mundo feminino”. In: História da vida privada, vol. 3, 2006, p. 371.
} 
da mulher o seu horizonte estava limitado ao recôndito doméstico, reduzindo ao máximo suas aspirações, encaixada no papel de "rainha do lar", sustentada pelo tripé mãe, esposa e dona de casa. Qualquer tentativa de flexibilização desta divisão de papéis era vista pelos conservadores como "uma ameaçadora vaga modernizante”. 68

Contra os surtos grandiosos do progresso que faziam oscilar o mundo alertavam eles, sejamos como a árvore poderosa arraigada ao solo, imutável, idêntica a ela mesma, procuremos no lar o ser estável que nenhum acontecimento pode abalar. ${ }^{69}$

Neste cenário, o casamento aparecia como uma etapa superior das relações amorosas e era proclamado como o "garantidor da saúde da humanidade”70, razão pela qual era importante divulgá-lo e transformá-lo numa necessidade para todos os componentes da sociedade. Qualquer relação entre homens e mulheres que se configurasse fora do contrato matrimonial era classificada como indecente.

Foram, porém, as camadas mais baixas da população - operários, imigrantes, mulheres pobres, mulheres sós, negros e mulatos - que tiveram o comportamento mais fiscalizado e submetido a medidas prescritivas. As múltiplas e improvisadas formas de união amorosa nesses segmentos receberam especial atenção das camadas médias e altas, bem como dos intelectuais conservadores e dos clérigos. Decididas a institucionalizar o amor com vistas a sustentar uma determinada ordem social, as elites transformaram em ameaça os relacionamentos ajustados por padrões mais flexíveis e simétricos, classificando de imorais as uniões cujo epílogo não coincidia com o casamento. ${ }^{71}$

As publicações voltadas para o público feminino eram, então, um meio de comunicação extremamente eficaz na campanha em prol do casamento e da família. Vários artigos eram dedicados às noivas, esposas e futuras mães. Guias de comportamento ensinavam desde como se preparar para a noite de núpcias, como organizar o jantar para receber o marido no final do dia, até idéias acerca de como organizar os serviços na casa

\footnotetext{
${ }^{68}$ Idem, p. 385

${ }^{69}$ Idem, p.385.

${ }^{70}$ Idem, p. 386.

${ }^{71}$ Idem, p.387
} 
durante a semana, de maneira que a mulher pudesse dar conta de tudo e no domingo descansar juntamente com a família.

A Revista Feminina, por exemplo, publicada entre 1914 e 1936, que possuía sede em São Paulo, era distribuída em todo país e continha uma quantidade enorme de conselhos para o sexo feminino. Era possível encontrar ali tanto matérias traduzidas de revistas estrangeiras quanto artigos assinados por escritores de renome no país. Nossos dramaturgos também participavam destas publicações.

Entre os colaboradores mais importantes encontra-se o escritor Cláudio de Souza que assinava os editoriais da revista com o pseudônimo de Ana Rita Malheiros, Coelho Neto, Antônio Austragésilo, Menotti del Picchia e as escritoras Júlia Lopes de Almeida e Chrysanthème. ${ }^{72}$

Chamam a atenção as regras que deviam ser seguidas caso as mulheres quisessem se encaixar no modelo de esposa exemplar. Na Revista Feminina, diversos artigos buscavam comprovar a importância de um bom casamento e, para auxiliar as mulheres já casadas, eram fornecidos conselhos, tanto no que se refere ao trato com o marido e os filhos, como no trato da casa, das roupas, da comida e da limpeza.

A esposa, a boa dona de casa sabe perfeitamente quais os gostos do marido, seus pratos preferidos e a maneira pelo qual os quer arranjados. Ela sabe tudo: o lugar que o marido gosta mais de estar, a cadeira escolhida, o descanso para os pés (...) Quando o marido lê não interrompe, nem deixa perturbá-lo sem motivo. Mas se ele lhe fala do que a leitura sugere, a esposa mostra-se interessada - ou procura interessar-se pelo assunto - porque em tudo quer ser agradável ao marido, e isso agrada-lhe sem dúvida. Tudo isso são pequeninos nadas. Pois esses pequeninos nadas é que têm maior importância na vida. ${ }^{73}$

As mulheres entravam em contato também através dessas publicações sobre como deveriam se comportar em companhia de outros homens, além de lições sobre etiqueta, culinária, moda e trabalhos manuais. O fundamental era que ficasse claro para aquelas jovens mulheres a importância do casamento e que lhes permitissem descobrir as virtudes

\footnotetext{
${ }^{72}$ Idem, p.639.

${ }^{73}$ Idem, p.389.
} 
de ser uma boa mãe e uma esposa perfeita. O ambiente urbano era apontado como sinônimo de hostilidade; enquanto o lar símbolo de segurança.

"Hoje em dia preocupada com mil frivolidades mundanas, passeios, chás, tangos e visitas, a mulher deserta do lar. É como se a um templo se evadisse um ídolo. É como se a um frasco se evolasse um perfume. A vida exterior, desperdiçada em banalidades, é um criminoso esbanjamento de energia. A família se dissolve e perde a urdidura firme e ancestral dos seus liames.'Rumo à cozinha’! eis o lema do momento”, conclamava a Revista Feminina em agosto de $1920{ }^{74}$

O perfil traçado para as mulheres possuía ainda outras qualidades "tais como simplicidade, justiça, modéstia e humor, seu antípoda ameaçador era a moça dos tempos modernos, esbagachada e cheia de liberdades". ${ }^{75}$ No teatro, o modelo de esposa exemplar apresentado nestas primeiras peças do Trianon não era muito diferente daquele defendido pela imprensa.

Adelaide - Ah! As moças da cidade! Queria que as visse de manhã, quando se levantam, como eu vi: sem cabelos postiços, sem carmim no rosto, sem aquelas armações na frente, nos lados e até atrás! ... O homem que casa com uma mulher daquelas não encontra pela manhã, na cama a mulher com que se deitou. Deita com uma e levanta com outra...

Henrique - E durante o dia vive com uma terceira, sem saber ao certo, qual das três é a legítima do seu amor!

Adelaide - Aqui não. Quem se casa não corre perigo de se enganar de mulher. É sempre a mesma. Se visse a Rosinha quando se levanta! É como um passarinho, como uma patativa! ${ }^{76}$

Rosinha, da fazenda paulista de Flores de sombra, e Nair, da casa do subúrbio carioca de Onde canta o sabiá, pareciam desenhadas de maneira semelhante aos modelos divulgados pelas revistas voltadas para o público feminino da época - moças ingênuas, que amam a família, a terra onde nasceram e não se deixam levar pelos encantos do mundo lá fora, da cidade grande, de Paris ou do Rio de Janeiro. As comédias, assim como os artigos de revistas, realizavam uma operação de valorização de imagens convocando as jovens e

\footnotetext{
${ }^{74}$ Idem, p.372.

${ }^{75}$ Idem, p.390.

${ }^{76}$ Cláudio de Souza, obra citada, 1922, p. 134.
} 
futuras esposas a agirem da mesma forma. O teatro predominante no período, ainda que em chave cômica, demonstrava a mesma preocupação moralizante, a de transmitir e legitimar entre a população o modelo da boa esposa e do bom casamento.

\section{A flor dos maridos.}

Vencida a etapa da realização do casamento, surgia uma nova questão: a permanência do mesmo. A necessidade de transformação de alguns hábitos, não propriamente para flexibilizar o matrimônio, mas para torná-lo durável. No texto A flor dos maridos, de Armando Gonzaga, a discussão acerca do casamento vai além da conquista e da escolha de um bom partido; a questão se desdobra acerca de como fazê-lo perdurar. A comédia estreou em 1922, no Teatro Recreio Dramático, e depois foi remontada com grande sucesso em 1924, no Teatro Trianon, encenada pela Companhia Brasileira de Comédia, que ocupou este teatro durante o período de 1921 a 1924.

No primeiro ato, a descrição do cenário indica: "sala de visitas de uma casa de burgueses abastados". ${ }^{77}$ Como as outras comédias analisadas, todas as cenas se darão neste espaço íntimo, local onde a família se reúne e recebe seus convidados. A cena começa com Macário e Margarida que, enquanto esperam os convidados para um jantar, discutem o comportamento dos maridos de suas filhas. O primeiro é um marido exemplar, que não sai de casa sem a companhia da esposa, nunca falta aos compromissos familiares e, quando está fora, concede todas as satisfações necessárias. O outro é visto como um descuidado que janta fora de casa sem a companhia da esposa, vai ao teatro freqüentemente e nunca justifica as suas faltas em compromissos familiares. Margarida discorda em alguns aspectos do que diz Macário, porém não há como negar que o primeiro marido, o da filha mais velha, pareça exemplar e o outro, o da filha mais nova, um péssimo companheiro. As filhas, por sua vez, são vistas como responsáveis pelo comportamento de cada um. A esposa do marido exemplar conseguiu, através de vigilância extrema, manter o marido obediente e fiel, por isso é considerada a verdadeira merecedora de elogios, enquanto a outra, por não exigir muitas explicações, acabou por transformar o companheiro em um péssimo marido.

Na primeira cena, temos logo a sensação de que algo está por trás daquilo tudo, antevemos a verdade dos fatos e imaginamos o momento crucial em que acontecerá a cena

\footnotetext{
${ }^{77}$ Armando Gonzaga, Comédias. São Paulo, Livraria Teixeira, 1940, p. 2.
} 
inevitável: o desmascaramento do marido exemplar, a dissolução da imagem da "flor dos maridos”. Com a evolução da história, a primeira impressão se confirma: fica revelado que Valério, o marido exemplar mantém um caso com Minervina, a empregada da casa, mente para a esposa sobre compromissos no trabalho e não perde a ocasião de seduzir outras mulheres amigas da família. Enquanto Augusto, o marido que entra e sai de casa quando bem entende, mostra-se generoso, sincero - é o único a admitir que a ida a um cassino pode ser muito mais agradável que uma festa na casa de uma amiga da família - e não inventa desculpas para justificar o seu comportamento.

No final do segundo ato, aparece Minervina na festa onde estão todos reunidos para desmascarar Valério, que segundo ela é o homem que a seduziu e que acabou por fazer com que perdesse o emprego. Para o espanto de todos, na porta da casa de Mme. Brochado, Minervina se agarra a Valério, diz que o ama e que ele não pode abandoná-la. A cena esperada desde o início da peça, a que revela a outra cara do marido exemplar, é-nos, então, oferecida.

Essa estrutura dramática, que nos anos 1920 já aparecia fortemente assimilada pelos autores brasileiros e, em especial, por Armando Gonzaga, que escreveu perto de 90 peças, todas enfocando tipos retirados das famílias brasileiras, apresenta procedimentos pertencentes ao teatro ligeiro adaptados às lições da comédia realista francesa. Era um teatro feito para divertir, mas com pretensões moralizantes, ou ainda, um teatro ligeiro que se preocupava em discutir temas relacionados à família, ao casamento e à definição de papéis apropriados para os homens e as mulheres na sociedade.

O crítico teatral francês Francisque Sarcey, um dos mais importantes defensores do teatro realista em sua terra natal, apontava para a necessidade de clareza e estrutura lógica para a narrativa. Como pedra angular desta estrutura aparecia a scene a faire ou cena obrigatória. ${ }^{78}$ Esta consistia na efetivação de uma cena que, fortemente esperada pelo público, devia aparecer na trama. Devido a um encadeamento "natural” dos fatos a cena obrigatória surgia como se tivesse brotado da própria narrativa, uma cena sugerida pelas outras cenas, o que faz parecer incontestável a sua importância. A configuração precisa desta cena é desconhecida, mas a sua presença é fundamental. O texto dramático para o crítico francês devia apresentar-se com estrutura tão encadeada que devia gerar estes dois

\footnotetext{
${ }^{78}$ Marvin Carlson, Teoria do Teatro. São Paulo, Unesp, 1997, p. 272.
} 
movimentos: o primeiro, de antecipação, previsto pelo público; o segundo, de efetivação, concedido pela cena. A seu ver, este caminho entre a promessa criada pela peça e a satisfação desta aos espectadores representava a essência da proposta teatral. O autor deveria para isso construir uma narrativa lógica e coerente, a corrente dos acontecimentos deveria ser capaz de fazer o espectador prever a existência de uma determinada cena; a expectativa criada seria posteriormente satisfeita pelo autor, acrescentando detalhes que o espectador não havia imaginado.

A flor dos maridos, mesmo como uma comédia ligeira, encaixa-se nesta estrutura da comédia realista que, com variações observadas em diferentes autores, dominou o teatro francês até o final do século XIX. A cena do desmascaramento de Valério surge como exemplo de cena obrigatória, cena que não sabemos nem quando nem como exatamente se desenrolará, mas que possui presença garantida. Desde o início da peça somos preparados para esta cena e temos posteriormente a nossa expectativa satisfeita com a sua aparição.

Após ter sido descoberto, Valério primeiramente planeja o suicídio, mas logo descarta a idéia (romântica demais!) e exige da esposa o divórcio. A esposa que estava como vítima, acaba tornando-se vilã, pois ela é quem exagerava ao exigir do marido tantas satisfações. Por isso é levada a perceber os seus erros e promete mudar o seu comportamento para que o casamento não termine. Com a reconciliação do casal o ensinamento da peça fica claro: para o sucesso do casamento é preciso que o marido tenha liberdade. O final da trama parece menos interessado em intensificar o efeito cômico e mais preocupado em definir conselhos para que as mulheres saibam gerir um bom casamento. $\mathrm{O}$ que nos possibilita retomar a questão de que o mero divertimento se constituía como a única intenção destas comédias, e que seriam, portanto, desprovidas de pretensão estética. 


\title{
Capítulo 3
}

\section{Benjamin Lima e Renato Vianna: ruídos e rumores na recepção.}

\begin{abstract}
Vivemos muitíssimos de nós com a idéia de que a representação do ator, as técnicas de iluminação, do cenário, da indumentária ou da encenação são humildes fatos artesanais situados aquém dos problemas de engajamento político, e que existem, no teatro, aqueles critérios eternos de qualidade, absolutamente necessários, seja qual for a sociedade em que são utilizados. Ora isso é falso: o artesanato dramático também é engajado, todas as técnicas, até mesmo as mais "naturais", significam sempre alguma coisa.
\end{abstract}

Roland Barthes

Ao analisarmos as diversas produções dramatúrgicas das primeiras décadas do século XX no teatro brasileiro, observamos, como vimos, a predominância das comédias dramáticas, ou seja, de uma comédia que obedece aos princípios do drama burguês e se preocupa em determinar lições moralizantes para os espectadores. Se não tratarmos como aspectos "naturais" a escolha do gênero, dos temas e formatos das peças dramáticas, somos então lançados numa dupla tarefa: a primeira relacionada à leitura das entrelinhas dessas produções - que procuramos fazer no capítulo anterior - ; a segunda - que procuraremos desenvolver daqui por diante, neste e nos próximos capítulos - se refere à análise de propostas diferenciadas e presentes em experiências artísticas do mesmo período, que negavam o horizonte de expectativa desenhado pelas comédias de sucesso, desafiavam os preceitos estéticos predominantes e dessa forma se colocavam na contra-mão dos espetáculos bem recebidos pela crítica e pelo público. Se até aqui tratamos dos sucessos, dos espetáculos que agradavam facilmente, da estética dominante, a partir de agora trataremos dos fracassos, das tentativas malsucedidas, dos textos dramáticos e encenações recusados.

Nesse cenário de manutenção de um padrão estético, notamos que não somente a comédia era hegemônica, mas também outros aspectos se faziam predominantes em nossa 
cena teatral: os atores-estrelas, que exigiam que o espetáculo fosse todo realizado a partir de sua figura; a divisão de papéis feita a partir de tipos, recurso que, como o anterior, remonta a um teatro comum nos idos do século XIX; a constante falta de críticas contundentes à sociedade; a maneira preconceituosa com que eram compostos os personagens pobres, sempre uns grosseiros frente aos senhores brancos, mais gentis e confiáveis; ou ainda a quantidade expressiva de obras que se preocupavam em defender o casamento, base da sociedade burguesa, e legitimar normas de conduta para as mulheres, as quais deviam ser, acima de tudo, boas esposas.

Contudo, notamos também que apesar da soberania de determinada postura estética surgiam propostas que, ainda que sem o radicalismo das experimentações cênicas realizadas por artistas como Oswald de Andrade e Flávio de Carvalho, de uma maneira ou de outra, buscavam romper com esse padrão. Seja através do tema escolhido e do tratamento dado ao enredo - como no caso do escritor Benjamin Lima, que, mesmo sem se colocar de maneira totalmente contrária ao habitual, acabou por construir uma peça que negava certas expectativas ao apresentar um assunto da ordem do dia, a traição no casamento, mas desenvolvê-lo de maneira diversa do esperado -, ou através de modificações nos meios de produção - como no caso do dramaturgo, encenador e ator Renato Vianna, que buscou durante grande parte de sua prática artística criar um grupo teatral que se envolvesse nas diversas etapas da criação.

A contrariedade ao que era usual, se não agradava com facilidade, também não passava despercebida. Torna-se interessante notar como o desagrado causado pela cena diversa da comumente apresentada acabava por adensar o encontro com os espectadores, mesmo quando estes se sentiam incomodados com o que não concordavam ou com o que não entendiam.

A peça $O$ homem que marcha, de Benjamin Lima, que teve somente uma apresentação, incitou a reação de alguns espectadores, que se levantaram durante o espetáculo a fim de se pronunciarem contra o que se passava no palco. No caso de Renato Vianna isto se deu de modo ainda mais intenso, pois os seus trabalhos sempre causaram irritação ou falta de entendimento na crítica do período. A montagem de A última encarnação de Fausto, apesar de ter sido representada apenas três vezes, provocou a 
publicação de diversos artigos acerca da “desordem” em cena que o autor promoveu ao modificar certos procedimentos oriundos do teatro do século XIX, ainda respeitados no teatro brasileiro - como o fato do protagonista ocupar sempre o centro do palco e os coadjuvantes atuarem ao seu redor -, e reconhecidos pela crítica como regras que facilitavam o entendimento da cena.

A análise desses acontecimentos, cabe aqui ressaltar, precisa se dar em face das especificidades próprias ao contexto social brasileiro. Nenhuma novidade pode se dar num espaço vazio, qualquer inovação artística solicita ser observada em face do ambiente em que ocorre, em diálogo com as obras que preponderavam naquele contexto. As experiências citadas, portanto, precisam ser consideradas em meio à predominância de uma estética conservadora e vigorosamente contrária a qualquer tipo de inovação.

\section{Brechas para ponderações.}

O texto O homem que marcha, de Benjamim Lima, representado em março de 1925, colocou a discussão acerca da traição no casamento em cena, só que desta vez sem o final feliz presente, por exemplo, na comédia A flor dos maridos, de Armando Gonzaga, observada no capítulo anterior. A peça de Lima obedece, à primeira vista, aos princípios do drama rigoroso, com cenas encadeadas, diálogos que fazem mover a trama, porém apresenta um desdobramento diverso daquele comumente visto nos palcos brasileiros. Nesse sentido, pode ser apontada como exemplo de exceção no padrão geral de representação ou de quebra de expectativas na cena. Para começar, o procedimento da chamada "alta comédia” não é predominante, a trama não possui final feliz, o texto foi definido pelo autor como "farsa moderna".

Mais interessante, no entanto, é notar que ao tratar de um assunto que estava em voga, mas não submetê-lo de maneira rigorosa aos preceitos do drama burguês, que usualmente regiam as nossas comédias, o autor conseguiu construir brechas para o espectador, brechas reflexivas que surgem cada vez que expectativas para o desenrolar de acontecimentos são rompidas. Neste caso específico a quebra de expectativa ocorre quando o autor opta por construir uma história em que o marido não mata a esposa após descobrir 
que ela o trai com o seu melhor amigo. Opção relevante, já que nas primeiras décadas do século XX, este tipo de crime tornara-se comum entre nós.

O assassínio em tais casos, se vai tornando tão freqüente em nosso país que, segundo lemos em estatística publicada na Revista Feminina, de São Paulo, mata-se no Brasil uma mulher de duas em duas horas! O maior fator desse genocídio é o júri, que absolve regularmente os assassinos, é a moral defeituosa de nossa sociedade que readmite os assassinos em seu seio com foguetes e manifestações como se voltassem de heróicas façanhas de lavagem de honra. ${ }^{1}$

Ao quebrar a sequência lógica dos acontecimentos, baseada num suposto realismo, já que assim agiam os maridos frente à traição de suas esposas, a peça aponta para a possibilidade de outros desfechos, de outros desdobramentos que se espalham também para a vida social.

Ao adentrar o horizonte de expectativa da vida prática, a obra se torna capaz de participar do entendimento do mundo, de agir sobre o comportamento social. Pois, como aponta Jauss, a experiência da leitura logra libertar o espectador “das opressões e dos dilemas de sua práxis de vida, na medida em que o obriga a uma nova percepção das coisas”. ${ }^{2}$ Quando o artista propõe algo novo, está também argumentando a favor de outras mudanças. Uma obra de arte quando quebra com o comumente aceito consegue também ativar outros modos de análise da realidade, de atitude diante dos fatos sociais.

Jauss expressou esta circunstância com a idéia de que a experiência estética não é uma liberação de (os vínculos com a práxis do mundo da vida), mas uma liberação para (um comportamento modificado e com respeito a essa práxis). ${ }^{3}$

\footnotetext{
${ }^{1}$ Prefácio In: Benjamim Lima, Teatro de Benjamin Lima. Rio de Janeiro, Gráfica Editora Aurora, s/d, p.10.

${ }^{2}$ Hans Robert Jauss, A história da literatura como provocação à teoria literária. São Paulo, Ática, 1994, p.52.

${ }^{3}$ Daniel Innerarity, “La experiencia estética según Jauss”. In: Hans Robert Jauss, Pequena apologia de la experiência estética. Barcelona, Ediciones Paidós Ibérica, 2002, p.18.
} 
A mudança artística está intimamente ligada a mudanças em outras esferas, daí o engajamento perceptível em qualquer opção estética, desde a maneira de construir uma história, como podemos observar em Benjamin Lima, até os meios encontrados para a produção de um espetáculo, como as experiências realizadas por Renato Vianna.

Se, por um lado, aponta para outro desfecho que não o conhecido, subvertendo o tratamento dado ao tema, a peça de Benjamin Lima se afasta, por outro lado, da forma rigorosa do drama, estabelecendo uma estrutura não totalmente linear, com passagens que fazem referências às próprias opções cênicas, que assumem a teatralidade do evento e a própria presença do espectador na sala de espetáculo.

Na primeira cena, o espaço é descrito pelo autor como "sala de estudo em casa de Ramiro - à direita porta larga, em arco, de acesso à sala de visitas com reposteiro corrido”. O gabinete de trabalho com “mesa de trabalho ampla e atravancada de livros” serve como cenário central. O som do piano que se ouve na cena vem da sala de visitas, mas ela não é o espaço principal, ao contrário, está ao lado do espaço principal, ligada a ele, mas sem que possamos vê-la, sem ocupar o centro da cena. Ramiro e Henriqueta são apresentados; ficamos logo sabendo que o casal enfrenta dificuldades financeiras, que não possui dinheiro para pagar os empregados nem as contas da casa, que a ação dramática se inicia no dia do aniversário de Henriqueta e que o marido saiu de casa pela manhã sem lembrar-se do fato.

Ramiro, a fim de se desculpar, relata as dificuldades por que tem passado, já que sonha em possuir um semanário, mas não encontra quem o patrocine. Está pronto para sair em busca de um empréstimo junto ao irmão, quando Henriqueta lembra-lhe que Conrado, seu amigo de infância, chegará em breve. Ramiro tem logo a idéia de pedir o tal financiamento a Conrado, no que é incisivamente desencorajado por sua esposa.

Henriqueta - Estás louco. Tomar dinheiro emprestado a Conrado? Nunca, que o não consinto eu.

Ramiro - E esta! Então não te opões a que eu faça pedido idêntico a amigos de muito menor intimidade, até mesmo a simples conhecidos, e consideras o maior dos absurdos dirigir-me a Conrado? Conrado, o mais antigo e leal de todos os meus amigos, companheiro de brinquedo na meninice, de traquinadas na adolescência, das farras aos vintes anos?! Um irmão quase. 
Henriqueta - Por tudo isso, precisamente, não o deves importunar.

Ramiro - Mas isto é um paradoxo.

Henriqueta - Apenas bom senso, apenas senso comum. ${ }^{4}$

Aparece Conrado, que acabou de chegar de viagem e seguiu direto para a residência do casal. Ramiro, aparentemente convencido pela esposa, conversa rapidamente com o amigo, pede desculpas pela pressa e sai de casa deixando-o sozinho com Henriqueta. Conrado e Henriqueta, após certificarem-se que estão realmente sozinhos, aproveitam a ocasião para matar as saudades e fazer promessas de amor eterno. Ficamos, então, sabendo que Henriqueta e Conrado não são apenas amigos, mas amantes.

Em seguida, Ramiro volta para casa, percebe a risada de Henriqueta, entra de mansinho, observa os dois juntos na sala de visitas e compreende que está sendo traído. Num impulso, Ramiro segue para o escritório, abre uma gaveta e dela tira uma pistola. Nesse momento, no entanto, a rubrica se modifica e, em uma descrição que se difere de outras habitualmente vistas nas peças desse período, acompanhamos em detalhes a movimentação de Ramiro, a transformação interna e, por conseqüência, externa do personagem.

Após uns instantes de indecisão, dirige-se com passos de autômato para sua mesa. Senta-se a ela sem rumor. Abre uma das gavetas e dela tira uma pequena pistola. Depõe esta sobre a mesa e queda em meditação. De súbito, à evocação de algum episódio, fuzila-lhe nos olhos um clarão de malícia com qualquer coisa de diabólico. E, lentamente, um sorriso que nasceu dos olhos, desce para os lábios, espraia-se-lhe por todo o rosto, converte-se afinal em riso convulsivo, sardônico, dolorosamente voluptuoso, mas silencioso em absoluto. Guarda a pistola. Ergue-se vai à porta da esquerda e de lá irrompe, como quem acaba de chegar, com estrepitosa alegria, fazendo que se apercebam, na sala, a mulher e o amigo, de sua chegada. Imediatamente surge Henriqueta à porta da direita, seguida, a pequeno intervalo, por Conrado. ${ }^{5}$

\footnotetext{
${ }^{4}$ Benjamin Lima, O homem que marcha. In: Teatro de Benjamin Lima. Rio de Janeiro, Gráfica Editora Aurora, s/d, p.27.

${ }^{5}$ Benjamin Lima, obra citada, p.41.
} 
O primeiro ato termina com a interrupção dos fatos, tal como poderiam se desdobrar, e instala-se o suspense acerca do desenvolvimento da história. Notamos, no entanto, desde já, que Ramiro decidiu não atirar no casal de amantes e tampouco revelar ter conhecimento sobre a relação entre eles. No segundo ato, a casa aparece mais arrumada, o gabinete que possuía na primeira cena "mobiliário pobre, mas com pretensões a conforto" aparece agora com móveis caros e luxo antes inexistente. O cenário anuncia, desta forma, que o casal Ramiro e Henriqueta está com a vida financeira acertada. Porém, em seguida, fica também esclarecido que para resolver as dificuldades financeiras, Ramiro desfruta do dinheiro do amante de sua mulher, o qual serviu para financiar o semanário com o qual tanto sonhava e que é também do bolso de Conrado que sai todo o dinheiro necessário para os gastos de Henriqueta e da casa. A situação parece controlada por Ramiro, que exige que Conrado pague até mesmo os bilhetes para o teatro. Os amantes, por sua vez, passam de enganadores a enganados.

No terceiro ato, a farsa criada pelo marido chega ao fim. Ramiro, ao receber uma negativa de empréstimo de Conrado, proíbe-o de aparecer em sua casa e Henriqueta entra em desespero com o telefonema do marido que anuncia a briga com seu amante. O conflito é acentuado com o relato de Ramiro de como tudo se passou, desde o início quando descobriu que estava sendo traído e resolveu realizar tal plano, até o momento atual, quando se cansou da representação. Fica então esclarecido para todos que Ramiro pedia empréstimos a Conrado, que nunca pretendia pagar e, além disso, tencionava fazer com que este acreditasse que Henriqueta era sua cúmplice na situação.

A quebra da estrutura fechada do drama, que somente se atém ao presente e nunca ao passado, intensifica-se a partir do relato de Ramiro. O marido recorre ao passado para explicar os motivos de sua conduta e nesta narração retoma os fatos como quem discorre sobre uma cena, ou melhor, uma farsa protagonizada pelos três, ele mesmo, a mulher e o amante.

Ramiro - Ouve o resto. Ali, junto daquela mesa, estive de arma na mão, decidido a ir matálos, na mesma atitude impudica. Teu riso continuava a perseguir-me, a provocar-me. Que indecência! Já me sentia assassino, gloriosamente. De súbito, uma lembrança me veio: da exaltação 
com que meia hora antes, me suplicavas, me ordenavas que não solicitasse jamais, jamais o auxílio de teu amante. Tive a genial inspiração. Estava ao meu alcance castigar-te melhor, muito melhor. Guardei o revólver. Falei alto para preveni-los de minha volta. E comecei a farsa sinistra que só agora terminou: a do homem que sabe, e faz mesmo questão de demonstrar que sabe. ${ }^{6}$

As referências ao teatro surgem, a partir de então, diversas vezes e se configuram como interrupção do fluxo dramático. A quebra desse fluxo é inclusive observada pelo próprio personagem que, ao ser interrompido pelos criados - os quais se colocam de maneira cômica com ouvidos colados nas portas a fim de escutar o que se passa lá dentro no momento em que partia para agredir a mulher, aponta que a distração que ocasionou a interrupção do drama restituiu-lhe a calma e o salvou de agir de maneira violenta.

Ramiro - Isso! Não há inconveniente que me insultes. Ao contrário... Podes provocar-me. Estou vacinado contra as cóleras. Efeito daquele intermezzo cômico dos nossos criados. Boa gente! É o caso de lhes gritar como o outro: Ah! Les braves gens! ${ }^{7}$

Mário Nunes, crítico da época, comentou alguns aspectos dessa peça e entre os defeitos destacou justamente a cena acima, afirmando que "a curiosidade dos criados corta a intensidade da cena capital”. ${ }^{8}$ Mas as referências ao teatro na peça não param aí: Conrado no terceiro ato pede licença, pois "parece que se prolonga demais esta cena”. ${ }^{9}$ Ramiro em seguida confessa que a farsa que representou lhe causou, ao mesmo tempo, prazer e sofrimento e o desenlace desta, segundo ele, havia sido precipitado devido ao seu esgotamento, já que não suportava mais representar, tal como se faz no teatro. O personagem assinala que se aquilo fosse episódio de comédia o público, naquela altura de sua confissão, já o teria vaiado, tal o tamanho de sua fala:

\footnotetext{
${ }^{6}$ Benjamin Lima, obra citada, p.99.

${ }^{7}$ Benjamin Lima, obra citada, p.96.

${ }^{8}$ Mário Nunes, 40 anos de teatro, volume II, Rio de Janeiro, Serviço Nacional de Teatro, s/d, p.155.

${ }^{9}$ Benjamin Lima, obra citada, p.96.
} 
Ramiro - E eu, que não sou máquina de sacrifícios, que já estou farto de sacrifícios, deixaria o palco, iria arrancar do buraco onde estivesse escondido, verde de pavor, o desastrado autor da peça. Sério que iria. E ele viria receber sozinho como de justiça, a formidável vaia. É que estou a declamar verdadeiro, interminável monólogo, coisa inadmissível no teatro moderno. (...) Procuro a minha última frase, e não a encontro... É indispensável para que o pano caia bem. ${ }^{10}$

A última palavra de Ramiro antes de cair o pano é “cocotte”, um insulto tremendo na época que se referia às meretrizes, dirigido a Henriqueta. A rubrica final aponta que após a última fala este sai "sorridente, cortês, feliz, descuidoso como um estudante em férias". 11 Fica claro, portanto, no final da trama, o quanto o casal de amantes deve ser punido. Henriqueta, principalmente - a esposa que gostaria de tornar imaculado "um amor que era em si mesmo, irremediavelmente impuro" ${ }^{12}$ - é castigada de maneira cruel. Os dois vêemse desmascarados e o relacionamento desmanchado.

Nesse sentido a peça não se afasta dos ensinamentos moralizantes das peças realistas francesas, mas existem ali quebras de padrões estéticos que merecem ser observadas. A referência ao teatro e mais especificamente ao público e à possibilidade de ser vaiado em cena surge como um procedimento moderno, de assunção da teatralidade, que nota a presença do espectador e o toma como interlocutor. A artimanha de Ramiro frente à traição, assim como a ironia destacada pela rubrica final da peça, desfaz algumas certezas acerca da importância do núcleo familiar, dessacraliza o casamento como instituição que deve ser preservada a todo custo. O homem que marcha procurou discutir uma questão que interessava à população e a desenvolveu de maneira inesperada, ou seja, não seguiu a expectativa conhecida e, desta forma, colocou em xeque a atitude comumente aceita do marido traído. A mudança brusca de Ramiro, que resolve não matar a mulher e o amante, abre espaço para a discussão acerca do casamento e das relações familiares.

A maneira como tal procedimento atingiu os espectadores também chama a atenção neste drama. O efeito da peça foi de espanto, segundo descrição de Mário Nunes. Quando o marido, após descobrir a traição, decide não matar a esposa, houve entre os espectadores

\footnotetext{
${ }^{10}$ Idem, p.102.

${ }^{11}$ Idem, p. 103.

${ }^{12}$ Idem, p.99.
} 
quem se sentisse diretamente ofendido e quisesse tomar a palavra para se fazer ouvir dentro da sala de espetáculos.

Estávamos na cena em que, logo após o primeiro diálogo com o marido, a esposa infiel nos revela seus culposos amores com o amigo íntimo da casa, o traidor Conrado. Chega a vítima da rua, surpreende o crime, corre a um "bureau" empunha o revólver. O homenzinho e os do seu grupo exultam: a honra vai ser lavada. Mas não, o marido muda de idéia, guarda o revólver, simula regresso estrepitoso e abre os braços à mulher e ao amigo... Indecência! O pano cai. O homenzinho toma a palavra. O que ele diz com o aplauso dos seus, pode ser aquilatado pela qualificação que deu à peça, no último “meeting” que realizou: um ultraje à família brasileira! ${ }^{13}$

Os espectadores que estavam no Teatro Recreio, aos quais se referiu o crítico, preferiam um final moralizante e não um final inesperado, uma possibilidade diferente de desfecho. Os espectadores queriam que a expectativa da vida diária fosse cumprida. A partir do relato de Mário Nunes acerca da reação do público notamos um conteúdo tratado de maneira diversa do habitual, que se estrutura em tensão com a forma e que, por sua vez, atinge diferentemente o espectador. O efeito do espetáculo torna-se, então, distante do esperado.

No procedimento adotado por Lima surge um espaço para a ponderação do espectador, espaço tantas vezes difícil de ser visto quando se trata de uma comédia ou de um drama bem-feito. A engrenagem perfeita estava em desarranjo na peça de Lima e a exasperação do espectador no meio do espetáculo confirma esta diversidade. Ao se dirigir ao espectador, ao assumir a presença deste na sala de espetáculos, a cena criada por Lima se aproxima de experiências de cunho moderno que tinham como atitude revolucionária a explicitação da relação entre palco e platéia. Os artistas modernos ao "enxergarem” o espectador na sala propunham a intensificação desta relação e sugeriam, ao mesmo tempo, inúmeras possibilidades de adensar este encontro. O desenvolvimento da trama diverso do esperado, nesse caso, aproximou o espectador da cena; o espaço de reflexão criado pelo autor convidou para uma recepção diversa, marcada pela contrariedade.

\footnotetext{
${ }^{13}$ Mário Nunes, obra citada, p.155.
} 


\section{Premiação negada.}

O homem que marcha, como foi dito, fez apenas uma apresentação, no dia $1^{\circ}$ de março de 1925, à qual se referiu o crítico Mário Nunes na crítica acima citada. No ano seguinte, o texto foi inscrito para participar de um Concurso Literário organizado pela Academia Brasileira de Letras. O concurso incluía prêmios para dramaturgia e também outras modalidades, tais como ensaios críticos, estudos históricos, poesia, contos e romances. Na lista de peças inscritas aparecem, além de Benjamim Lima, autores de prestígio no período tais como Abadie Faria Rosa e Paulo de Magalhães. A Comissão Julgadora responsável pela avaliação das obras dramáticas contava com a presença de Cláudio de Souza, Coelho Neto e A. Austregésilo e escolheu, por unanimidade, a peça $O$ homem que marcha para receber o prêmio.

O assunto em suas linhas gerais não é inteiramente original, nem há mais assuntos originais em teatro, principalmente no capítulo adultério, que é da especial predileção do teatro francês, tanto antigo como moderno. Se não há mais assuntos originais em teatro, há modos originais de tratar os que sejam mais corriqueiros. E o Sr. Benjamin Lima deu muita originalidade à obra que nos apresentou, e que, infelizmente, foi à cena apenas uma vez, quando outras repetem centenários nos cartazes da futilidade. ${ }^{14}$

O prêmio, contudo, não foi concedido. Dois membros da Academia, Osório Duque Estrada e Carlos de Laet, se opuseram a tal escolha e impugnaram o parecer da Comissão. O primeiro alegou que o gênero ao qual se filiava a peça - o autor a tinha denominado “farsa moderna” - não se adequava às categorias previstas pelo concurso e o segundo, conhecido como um católico fervoroso e avesso às invenções modernistas, considerou a peça imoral. A premiação foi então suspensa e a Comissão Julgadora foi obrigada a apresentar uma réplica.

O texto de réplica foi então redigido, no qual os componentes da Comissão defenderam de maneira minuciosa os méritos da peça. Através de um verdadeiro tratado

\footnotetext{
${ }^{14}$ Revista da Academia Brasileira de Letras, vol. XXIV, Edição do Anuário do Brasil, Rio de Janeiro, s/d, p.124.
} 
sobre obras fundamentais da história do teatro e da literatura e de seus temas, os autores apontaram que caso aquelas obras primas fossem submetidas ao crivo da Academia Brasileira de Letras corriam sério risco de serem também consideradas “imorais”.

Nesta rápida excursão em que vamos, detenhamo-nos um momento na Alemanha. Como classificar a moral de "Werther", obra que tem provocado mais suicídios do que as letras de seu texto? Tema pernicioso, de influência nociva ao espírito e degradante para a individualidade, é, entretanto, como obra de arte, das mais altas culminâncias das letras. Traduzida em todas as línguas, admirada em todas as nações, traz-nos o consenso universal de que a obra de arte deve ser encarada pela arte, e não por qualquer outro prisma, quando se quiser avaliar de seu mérito criador. ${ }^{15}$

O texto apresentado pela Comissão para a defesa de sua decisão em prol da peça de Lima foi extenso, resultou em vinte páginas, que foram publicadas na Revista da Academia. ${ }^{16}$ A decisão dos membros contrários à premiação, no entanto, foi implacável. Em sessão de 11 de novembro de 1926, Carlos de Laet redigiu um substitutivo que negava a premiação à peça de Benjamin Lima e ainda propunha que não fosse concedido prêmio, nem menção honrosa a qualquer dos trabalhos teatrais apresentados para o concurso daquele ano. E assim foi feito, o substitutivo foi votado e desta vez aprovado, ou seja, a premiação do texto de Benjamin Lima foi cancelada.

A exasperação causada nos espectadores do teatro relatada por Mário Nunes parecia se repetir entre alguns componentes da Academia. Os autores encarregados de julgar o mérito das peças teatrais enxergavam que a originalidade da forma com a qual Benjamin Lima tratou do adultério ultrapassava qualquer espécie de lição moral e chamavam atenção para o quanto a peça se diferenciava de outras obras do período: "se destaca do comum das peças que constituem o repertório nacional”. ${ }^{17}$ A novidade da forma encontrada na peça de Lima, que a aproxima de uma proposta moderna de encenação, e a subversão do enredo, que propõe uma discussão acerca do que parecia normal, não passou despercebida para os

\footnotetext{
${ }^{15}$ Idem, p. 226.

${ }^{16}$ Ver texto completo na Revista da Academia Brasileira de Letras, volume XXIV, Edição do Anuário do Brasil, Rio de Janeiro, s/d. Parte do mesmo texto encontra-se no Prefácio do livro de Benjamin Lima. Teatro de Benjamin Lima. Gráfica Editora Aurora, Rio de Janeiro, s/d, pp.7-15.

${ }^{17}$ Idem, p.122.
} 
membros da Academia, nem aos olhos dos que a consideraram a vencedora, nem tampouco para aqueles que a consideraram imoral e vetaram a sua premiação.

Vale a pena lembrar ainda que mesmo os componentes da Comissão que aprovaram O homem que marcha, não eram autores com posturas consideradas inovadoras, ao contrário. Coelho Neto, por exemplo, foi diversas vezes atacado por Oswald de Andrade como representante de uma literatura conservadora e adepto de procedimentos arcaicos. A própria Academia foi alvo de ataque constante de Oswald. Em 15 de outubro de 1925, ou seja, um ano antes da polêmica em torno da peça de Lima, Oswald de Andrade escreveu carta aberta à Academia Brasileira de Letras a fim de pleitear uma vaga na instituição. De maneira irônica, Oswald se dirigiu aos "Senhores Imortais” para expor sua plataforma, apontando entre outras coisas que "a Academia desmente o espírito com que foi fundada” e que a sua candidatura revelava uma forma de protesto, pois estava convencido de que:

Dos vossos nobres escrutínios só pode sair a derrota de uma pretensão que não entra no meu feitio - todos sabem. Eu de farda - (eu e mais do que eu, qualquer dos modernistas brasileiros solidários com a mocidade heróica de Graça Aranha) - é um anacronismo tão grave como Osório Duque Estrada de bicicleta. A minha candidatura ficará sendo o altifalante de uma queixa - a dos milhares de intelectuais de minha terra, escarnecidos pela cavação da expoência, quando não pela expoência da cavação. ${ }^{18}$

A postura moderna e o radicalismo das propostas do autor de $O$ rei da vela passavam longe das intenções observadas em Benjamin Lima. No entanto, a queixa de Oswald, feita um ano antes do ocorrido, pode bem ser colocada ao lado da discussão que envolveu a peça de Lima e talvez nos ajude a assinalar um dos aspectos marcantes do veto ao modernismo nas três primeiras décadas do século $\mathrm{XX}$ : não precisava ser muito subversivo da ordem para ser considerado imoral ou censurado pelos intelectuais de prestígio em nossa sociedade; qualquer pretensão de enfrentamento ao estabelecido proposto pela cena era, de antemão, considerado abusivo.

\footnotetext{
${ }^{18}$ Oswald de Andrade. In: Maria Augusta Fonseca, Oswald de Andrade: biografia, São Paulo, Globo, 2007, p.167.
} 
O veto se efetivava como marca indelével da relação entre teatro e sociedade brasileira no período. O que nos possibilita também analisar o caso citado a partir da formulação de uma questão: se as experiências de Benjamin Lima causaram tanto alvoroço, levando a montagem a conseguir uma única apresentação - atacada pela Academia, pela crítica especializada e pelos próprios espectadores -, o que esperar da recepção concedida às ousadas invenções de artistas como Flávio de Carvalho e Oswald de Andrade? Questão esta que pode ser desdobrada em outras, fundamentais para esta investigação, e que podemos retomar aqui: se Benjamin Lima não conseguiu mais que uma apresentação de sua peça, não seria surpreendente que Oswald conseguisse levar à cena os seus textos? A contrariedade, própria às vanguardas artísticas do início do século XX, poderia lotar teatros, efetivar longas temporadas e obter boa acolhida crítica entre nós? Em face do referido contexto histórico, poderíamos esperar um modernismo retumbante em nosso teatro? Não foi deste modo, vigorosamente sufocado, que o modernismo se deu no teatro brasileiro de então? A falta de reconhecimento deste modernismo não pode se constituir como perpetuação do veto?

\section{As propostas de Renato Vianna.}

A montagem de Renato Vianna de A última encarnação de Fausto realizada em dezembro de 1922, no Teatro São Pedro, não apresenta uma história brasileira balizadora dos valores tradicionais, não defende a família, nem o casamento. O adultério está presente na história, mas não se constitui como problema central. A trama, inspirada no mito de Fausto, narra a história de Eduardo, um artista bem sucedido que em busca de uma vida em êxtase acaba por fechar um pacto com Mefistófeles, o qual exige dinheiro no lugar da alma.

A forma com a qual o autor construiu o espetáculo - utilizando-se de elementos estranhos à cena brasileira, tais como pausas significativas colocadas entre as falas dos personagens, além de efeitos de luz e som que buscavam acrescentar um sentido poético aos momentos significativos da peça, e soluções cênicas que sublinhavam a subjetividade dos personagens - opunha-se às expectativas de resolução dramática do público. Ao adentrar o universo psicológico (intrasubjetivo) e interromper o diálogo contínuo do motor do drama (intersubjetivo), o autor tornava a sua presença visível, agia como um narrador 
por detrás do texto e, desta maneira, sugeria inevitavelmente a quebra da rigorosa estrutura dramática presente em nossas comédias. Um espetáculo assim concebido apresentava-se como uma encenação, no sentido moderno do termo, e exigia, na contramão dos hábitos de recepção da época, uma nova atitude interpretativa.

Nas diferenças entre esta encenação e os espetáculos citados anteriormente, no jogo de perguntas e respostas estabelecido não somente pela cena, mas também pelo texto, na proposta de criação contrária ao comumente executado no teatro brasileiro do período, no risco assumido ao colocar em cena uma temática de difícil compreensão e questionadora da posição do homem frente aos desafios de seu tempo, aparecem os lances modernos do teatro elaborado por Renato Vianna. Contudo, uma montagem que pode bem ser apontada como espetáculo que enfrentou os desafios das experiências de vanguarda no âmbito teatral, no mesmo ano da Semana de Arte Moderna, porém, considerada um fracasso pela crítica da época, recebeu raros registros dos historiadores do teatro brasileiro.

\section{Trabalho coletivo.}

Renato Vianna optou para a construção desse espetáculo a formação de um grupo teatral, que foi denominado A Batalha da Quimera. O nome do grupo, “em clara alusão a Les Compagnons de la Chimère, de Baty - definia os princípios e as vertentes que norteariam a trajetória artística de Renato Vianna”. ${ }^{19}$ O diretor francês Gaston Baty, era seguidor de Jacques Copeau e fundara a sua companhia em 1921, em Paris. Por aqui, Renato Vianna, ao que parece, acompanhava com interesse, através de revistas e outras publicações estrangeiras, a luta de dignificação do trabalho do ator e a defesa de respeito ao texto, principais preceitos defendidos por Copeau, desde a abertura do Vieux Colombier, em $1920 .^{20}$

\footnotetext{
${ }^{19}$ Iwens Thiwes Godinho, Renato Vianna: educador e dramaturgo. Dissertação de Mestrado, Centro de Letras e Artes da Universidade do Rio de Janeiro UNI-RIO, 1998, p.38.

${ }^{20}$ Sebastião Milaré, A batalha da Quimera, obra inédita, 2001, p.51.
} 
Todos os axiomas, toda a teoria violenta e sublime daquele Copeau da batalha do Vieux Colombier, fora assimilada por ele, tornava-se Evangelho, e dificilmente havia de o largar durante toda a vida. ${ }^{21}$

Caracterizar Vianna unicamente como um seguidor dos princípios de Jacques Copeau, no entanto, nos parece pouco esclarecedor para a compreensão de sua trajetória. O fato das montagens da escola francesa de Copeau e seus discípulos do Cartel dos quatro (Dullin, Baty, Jouvet e Pitoeff) impressionarem Vianna e também outros escritores brasileiros - Alcântara Machado foi também um admirador do trabalho de Copeau - se devia principalmente às transformações nos meios de produção artística propostas pelo grupo.

A escola francesa deplorava o comercialismo e o exibicionismo do teatro de bulevar, rejeitando o barateamento estético de artistas e público, ênfase que muito inspirou a cruzada antimercantil de Alcântara Machado. Copeau foi um dos maiores críticos europeus da inércia e da mediocridade do gosto cultural, condicionadas pelo padrões de consumo. Por outro lado condenava a radicalidade pragmática das vanguardas européias, a pretexto de negar qualquer "originalidade vistosa demais". 22

Em um país que não conseguia se desvencilhar nem mesmo da função do ponto, artistas que experimentavam a reformulação dos meios de produção, com o abandono da figura da vedete como centro do espetáculo, com o estudo aprimorado do texto e dos personagens, tal como pregavam os diretores franceses, caíam como uma luva na realidade brasileira. Outro traço marcante que podemos identificar em Vianna, semelhante aos ensinamentos de Copeau, estava no seu desejo manifesto de criação de uma escola onde os artistas pudessem trabalhar em conjunto e aprofundar os seus conhecimentos.

A companhia organizada por Renato Vianna era constituída por um grupo de artistas em oposição ao esquema de atores-estrelas que encabeçavam as companhias de teatro da época. O próprio Renato Vianna havia trabalhado anteriormente com grandes

\footnotetext{
${ }^{21}$ Brício de Abreu, Esses populares tão desconhecidos. Rio de Janeiro, E. Raposo Carneiro Editor, 1953, p.227.

${ }^{22}$ Sérgio Ricardo de Carvalho Santos, O drama impossível. Tese de doutoramento em Literatura Brasileira. Faculdade de Letras e Ciências Humanas da Universidade de São Paulo, 2002, p.69.
} 
estrelas do teatro brasileiro, suas primeiras peças contaram com a presença da famosa atriz dramática Itália Fausta e, com o ator-empresário de maior prestígio na época, Leopoldo Fróes. A opção por um grupo teatral, portanto, era sinal importante da vontade de rompimento com a forma usualmente adotada, inclusive por ele mesmo, na realidade teatral brasileira.

A Batalha da Quimera foi o primeiro grupo organizado por Vianna, que posteriormente organizaria mais três, e contava no elenco com a atriz Lucília Peres, que já havia sido estrela de companhia juntamente com Leopoldo Fróes, mas no momento em que foi convidada não simbolizava uma estrela chamariz de público. Além de Lucília estavam no elenco o ator português Antonio Ramos, que já havia trabalhado com Vianna em dois outros espetáculos - Na voragem e Os fantasmas -, Mário Arozo e o próprio Renato Vianna. A peça possuía um coro, que, segundo indicações do texto, era executado por jovens atrizes. O cenário ficou por conta de Mário Túlio, cenógrafo de prestígio no período e como iluminador a Companhia contou com a execução do eletricista Cadete. Podemos observar a relevância da função de iluminador neste espetáculo, já que Renato arriscou desenhar a luz de maneira complexa e totalmente diversa do que se fazia no período. A encenação contava ainda com música, composta especialmente para o espetáculo, de Heitor Villa Lobos. Ao constituir um grupo de trabalho, o autor revelava não somente o desejo de transformar o resultado, mas em rever os âmbitos da produção, em modificar o processo de criação.

Para ele, a estética e a realidade social se determinavam mutuamente. Não há possibilidade, no teatro, de se impor formas estéticas válidas e conseqüentes sem ter por referência a realidade social. O teatro de então ia a reboque da sociedade e o que Renato propunha era um teatro que não fosse retaguarda, mas vanguarda social. Inspirava-se nas modernas correntes teatrais da Europa e tentava encontrar novos meios que propiciassem ao teatro expressar criticamente a realidade social com o fim de modificá-la. Procedimento que não apenas reflete o espírito mais avançado daquele tempo, como o aproxima virtualmente dos modernistas. ${ }^{23}$

A idéia de trabalhar em conjunto contrastava tanto com a realidade social quanto com a estética predominante. Numa sociedade que mal se definia como um conjunto de

\footnotetext{
${ }^{23}$ Sebastião Milaré, obra citada, p.3.
} 
cidadãos com direitos e capacidades semelhantes, a arte era encarada como artigo supérfluo sem nenhuma espécie de subsídio ou interesse de desenvolvimento por parte do governo. O habitual eram espetáculos feitos em torno de um ator-estrela, executados às pressas, sem tempo para estudos minuciosos da cena ou de personagens.

A presença do ponto, por exemplo, comum no teatro brasileiro até meados dos anos 1940, tornava os ensaios uma etapa dispensável, “principalmente para as estrelas que só chegavam mesmo no último instante para ocupar o seu lugar no centro do palco". ${ }^{24}$ A justificativa revelada pelo ator Leopoldo Fróes para sua ausência nos ensaios tornou-se emblemática para ilustrar esse tipo de comportamento:

Na verdade, eu falto apenas aos primeiros. São tão aborrecidos os primeiros ensaios de uma peça!... A leitura monótona, arrastada, madraceirona dos papéis; as dúvidas, as discussões suscitadas pelos erros do copista, a minuciosidade das marcas: "passa a 1, desce a 2, dirige-se à esquerda baixa, sai pelo fundo”. É como digo em cena, quando me esquece a frase seguinte, “uma coisa horrível”! Tenho tentado resignar-me, afeiçoar-me àquelas estopadas iniciais. Não posso! A minha presença com bocejos que eu não conseguiria disfarçar, os sinais de nervosismo impaciente que não deixaria de dar, só serviriam para criar dificuldade para ao ensaiador, perturbar a disciplina da troupe. ${ }^{25}$

A importância do ator era tão grande frente ao restante dos integrantes que era frequente na divulgação do espetáculo aparecer o nome da estrela da companhia em detrimento de qualquer outra informação sobre a peça. Apostar em um espetáculo sem estrela chamariz no elenco significava, por um lado, risco financeiro e, por outro, disposição para trabalhar de maneira diversa. A presença da vedete garantia a bilheteria de uma empreitada teatral, porém determinava também outros desdobramentos: “o estilo da peça, a técnica do ator vedete e as expectativas do público não deveriam divergir”. ${ }^{26} \mathrm{Ou}$ seja, quando falamos de espetáculos chefiados por uma vedete estamos também reconhecendo uma série de características que acompanha esse modo de fazer teatral.

\footnotetext{
${ }^{24}$ Ângela Leite Lopes, Nelson Rodrigues: trágico, então moderno. Rio de Janeiro, Nova Fronteira, 2007, p.24.

${ }^{25}$ R. Magalhães Jr., As mil e uma vidas de Leopoldo Fróes, Rio de Janeiro, Lisa, 1971, p.132.

${ }^{26}$ Sérgio Ricardo de Carvalho Santos, obra citada, p.21.
} 
Nesse sistema produtivo os atores principais trabalham sempre a partir de características pessoais, repetindo, em peças diversas, a mesma maneira de falar e gesticular em cena. “A personalidade do homem Fróes se misturava à dos galãs de ficção que se comprazia em representar" ${ }^{27}$; o texto, confeccionado seguindo as noções da peça bem feita buscava criar espaços para a exibição de dotes das celebridades. "É o teatro da carpintaria melodramática ou da intriga cômica a serviço dos artistas idolatrados por sua genialidade” ${ }^{28}$; os espectadores, por sua vez, corriam para o teatro a fim de rever e reconhecer as virtudes de seu ator preferido. Ou seja, o espetáculo se adaptava às exigências do ator e ambos se ofereciam a corresponder às expectativas conhecidas do público.

A força dos atores frente aos escritores pode bem ser compreendida com a luta travada entre diversos componentes da classe artística para que a fundação da SBAT (Sociedade Brasileira de Autores Teatrais), no ano de 1917, se tornasse possível. Leopoldo Fróes foi um dos que se colocou contrário à criação da Sociedade e, além de declarar-se contra o pagamento dos referidos direitos aos escritores de peças apresentadas por suas companhias, promoveu uma intensa campanha contra a organização dessa e, segundo consta, teria ameaçado o autor Gastão Tojeiro para que não entrasse para a Sociedade, caso contrário ele não mais encenaria as suas peças. Mais tarde, no ano de 1924, o próprio Renato Vianna travaria uma briga pública com Leopoldo Fróes, com cartas publicadas em jornais da época, em torno da defesa dos direitos autorais e da SBAT.

A ausência de atores-estrelas no espetáculo viabilizava algumas investigações em cena - a exploração dos diversos planos do espaço cênico, movimentando os atores no palco sem preocupar-se em manter o personagem principal no centro, a construção de silêncios e pausas dramáticas as quais exigiam ensaios e tempo dedicados para a compreensão do próprio personagem e da história como um todo - , tais mudanças representavam um verdadeiro desafio ao estabelecido no teatro brasileiro, e, talvez, fossem impossíveis com a presença das estrelas em cena, as quais carregavam consigo uma série de convenções no âmbito da interpretação abandonadas pelo espetáculo proposto por Renato Vianna em 1922.

\footnotetext{
${ }^{27}$ Idem, p.35.

${ }^{28}$ Idem, p.22.
} 


\section{O texto como desdobramento de outras obras.}

O texto elaborado por Vianna mostrava-se repleto de elementos inovadores, que os críticos da época, ao assistirem o espetáculo, consideraram ilegíveis. O procedimento moderno presente no texto pode ser observado através da justaposição do discurso dramático, das referências a outras obras que a peça aponta, do diálogo entre narrativas que o autor constrói sem deixar que as referências iniciais desapareçam.

A trajetória de Fausto é a referência principal, mas não a única. A figura de Don Juan, de Molière, portador de um tédio profundo provocado pela falta de crença em valores essenciais, também pode ser encontrada no Fausto de Vianna, além do universo dos dramas românticos, dos amores impossíveis guiados pela paixão que se vêem permeados pelo sofrimento. Além disso, quando a peça apresenta um Mefisto que vende porções em troca de dinheiro com o qual pagará as contas do alfaiate, a peça aponta para a sociedade carioca, suas preocupações, seus valores.

As referências a outras obras surgem na peça sobrepostas umas às outras, como citações que ajudam na construção da história principal e até mesmo na subjetividade da mesma. Cenas, falas e personagens que, reutilizados, auxiliam a formatação da trama e concedem-lhe um aspecto não linear. Na ocasião de sua encenação, a peça causou tamanho espanto que os críticos não sabiam como comentá-la, chegando algumas vezes a admitir que não conseguiam entender o que estavam assistindo.

O trabalho desse autor patrício, não duvidamos, pode até obter sucesso inigualável em Paris ou Berlim, em platéias de grande cultura. A nossa que há tanto espera pelo teatro brasileiro, é que não poderá compreender, ou ficar comovida com “A última encarnação de Fausto”, que manda a sinceridade que afirmemos, não nos foi possível entender. De modo que o que aí deixamos não é uma apreciação do trabalho do Sr. Renato Vianna: é um simples registro do início da Batalha da Quimera, e o encarecimento de seu grande esforço por uma arte que não podemos dizer se é boa ou má, mas lealmente confessamos inacessível ao nosso entendimento. ${ }^{29}$

\footnotetext{
${ }^{29}$ Crítica não assinada, “A última encarnação de Fausto”. A Noite, 19/12/1922.
} 
O estranhamento dos críticos era causado tanto pelo texto, que não se constituía como drama rigoroso, com início meio e fim, bem delimitados, que não contava com as regras da peça bem-feita e nem se assemelhava às comédias comumente apresentadas no teatro brasileiro de então, quanto pela encenação rica em signos sensoriais provocados pela luz e som intensamente utilizados em cena. Além disso, na sobreposição de histórias, apontada anteriormente, surgia uma outra sobreposição: a de gêneros e de suas características. Cada gênero carrega consigo uma série de informações, uma série de expectativas.

A obra que surge não se apresenta como novidade absoluta num espaço vazio, mas, por intermédio de avisos, sinais visíveis e invisíveis, traços familiares ou indicações implícitas, predispõe seu público para recebê-la de uma maneira bastante definida. ${ }^{30}$

Em cada ato, a peça de Renato Vianna apresentava “avisos” referentes a gêneros dramáticos diversos, exigindo desta forma uma atitude interpretativa também diferenciada, fato que também causava assombro nos críticos.

A princípio assentado mais positivamente a sua peça na obra imortal de Goethe, oferece-nos o Sr. Renato Vianna um $1^{\circ}$ ato que interessa e agrada, tanto pela linguagem como pelo arranjo teatral de idéias. De então por diante começa a confusão; o idealismo avigora-se, o simbolismo depaupera-se, o realismo perde-se ante as idealizações do real.

E a peça caminha, caminha sempre, através de uma verdadeira confusão de doutrinas e idéias, como que ao sabor, apenas, de uma imaginação escaldante e desorientada. ${ }^{31}$

A atitude interpretativa proposta aos espectadores por Vianna - como uma provocação moderna - contrariava as expectativas reinantes, inclusive daqueles conhecedores da obra de Goethe que poderiam esperar que a peça apresentasse uma adaptação do mito de Fausto à realidade brasileira. A peça oriunda da Batalha da Quimera obrigava o espectador a participar ativamente do jogo do texto, o qual revelava as fontes literárias inspiradoras e, ao mesmo tempo, as embaralhava.

\footnotetext{
${ }^{30}$ Hans Robert Jauss, obra citada, 1994, p.28.

${ }^{31}$ Otávio Quintiliano, “A batalha da Quimera”. O Jornal, 19/12/1922.
} 
O primeiro ato, descrito como "Sonho de Fausto"32 se desenrola como um devaneio e, ao mesmo tempo, como esboço de uma peça dentro de outra. O Artista acaba de chegar em casa vindo de uma festa, e, desde já, mostra-se entediado; ao observar a chama de uma vela acesa no castiçal de sua sala inicia uma espécie de delírio em que se remete à história de Fausto. Na versão de Goethe, Fausto ao clamar pela magia recebe o primeiro sinal de Mefistófeles através de uma labareda. Olhando para a chama, como quem observa um ser sagrado, o artista da peça de Vianna confessa escutar proveniente da chama um canto feminino, o canto é verdadeiramente executado como se vê pela rubrica, porém, como ressalta outro personagem o canto é um sinal de alucinação do patrão.

O Artista implora que a chama revele os seus segredos: "Revela-te a mim! Dá-me o teu segredo! Imprime na minha alma o teu gênio”. ${ }^{33}$ O Escudeiro o interrompe perguntando se está passando mal, porém o artista pede que o deixe sozinho e começa a observar uma estátua de mármore de sua autoria que está colocada no centro do palco.

A estátua é uma vaga forma de mulher nua, apenas recatada por uma gaze diáfana, que lhe cai da altura dos seios até aos pés. (...) A mulher está de pé, com os braços estendidos para trás, a amparar a cabeça voltada sobre a face esquerda, numa atitude lânguida de quem se espreguiça. ${ }^{34}$

Neste instante aparece ao fundo um novo e misterioso personagem, surge interrompendo a cena com três batidas no chão, como se anunciasse o início do espetáculo numa referencia às batidas imortalizadas na figura de Molière e também ao momento da aparição de Mefistófeles na obra de Goethe, em que este pede a Fausto que lhe peça para entrar não somente uma, mas três vezes, caso contrário ele não conseguirá. O personagem misterioso é denominado apenas Homem, surge elegantemente vestido com uma capa preta e a cena prossegue com a curiosidade do artista em torno da identidade do novo personagem. Depois de um longo diálogo, Eduardo consegue desvendar a figura misteriosa.

Artista (num grito) - Satanás!!!

Homem (levantando-se) - Foi meu pai!

\footnotetext{
${ }^{32}$ Os títulos de cada ato que utilizamos foram retirados da crítica ao espetáculo feita por Mário Nunes e consta em seu livro: 40 anos de teatro, vol.II, p.64.

${ }^{33}$ Renato Vianna, A última encarnação de Fausto. Arquivo SBAT, s/d., p.3.

${ }^{34}$ Idem, p.3.
} 
Artista - Mefisto!

Homem - Sou eu.

Artista (no auge da surpresa e como quem se reconhece a si mesmo, depois de um pesadelo ou de um delírio) Fausto! Fausto!

O reconhecimento da figura de Mefisto e da sua própria como Fausto indica o início da sobreposição de histórias. A partir desse momento as descrições dos personagens no texto não mais aparecem como Artista e Homem, agora as suas denominações são Mefisto e Fausto, como se esses personagens se sobrepusessem aos anteriores. As figuras do mito de Fausto surgem auxiliando a construir os dois primeiros, dando-lhes contornos, concedendo-lhes camadas. O diálogo com a obra de Goethe se estabelece desta maneira e convida o espectador a reconhecer nas identificações dos personagens uma espécie de legenda.

Envolvidos pelos papéis, os dois discutem o pacto, a razão do mesmo e, por fim, a forma de pagamento. Eduardo confessa que deseja viver em êxtase, que deseja animar a sua obra com uma beleza perfeita e isto não quer dizer uma perfeição plástica, ele precisa da beleza absoluta, a perfeição moral, que seja eterna e infinita. Mefisto sente estranheza diante do pedido do artista, considerando-o ultrapassado:

E, francamente, nunca pensei em encontrar em um ambiente tão moderno, e em um artista tão civilizado, o mesmo Fausto da câmara gótica e dos laboratórios, ensandecido pela ânsia do infinito. ${ }^{35}$

Após questionar o diabo e a si mesmo se aquilo que está acontecendo é mesmo verdade ou sonho, Eduardo resolve levar a trama adiante e propõe que fechem logo o pacto com a assinatura do contrato de cessão de alma. Porém Mefisto retruca, não é a alma que deseja do seu interlocutor, mas o dinheiro.

Antigamente eu colecionava almas, porque as almas eram o "bric-a-brac" de antigamente. Era moda. Como tal passou... É provável que volte ainda, porque a evolução é um círculo vicioso.

\footnotetext{
${ }^{35}$ Idem, p.9.
} 
Neste momento, porém, é mercadoria avariada, e uma alma não vale um marco no câmbio atual. Hoje coleciono notas de banco. ${ }^{36}$

No lugar de uma assinatura com sangue o diabo pede que Fausto feche o acordo assinando um cheque. Mefisto faz uma conta rápida, pensando na fórmula que venderá ao artista, sugere mil libras e os dois fecham negócio. A cena termina com Fausto recebendo uma porção preparada por Mefisto, que deve ser ingerida com um pouco de água. Fausto indaga acerca do que pode lhe acontecer, no que Mefisto responde:

Nada receies. Os médicos não fazem outra coisa se não envenenar a humanidade. Entretanto têm o título de curadores. Bebe! (Fausto hesita) É néctar. ${ }^{37}$

Mefisto, enrolado em sua capa realiza, “passes mágicos” por todo o corpo de Fausto que se encontra adormecido após ter ingerido a bebida, o diabo prepara-se então para partir, porém antes se despede e com um gesto de saudação e declara: “Artista! Meu eterno Don João Fausto!”. 38

A obra de Goethe, inspirada na Historia von Dr. Johann Faustus, de meados do século XVI, data do final do século XVIII e abriu novos caminhos para a compreensão do mito de Fausto. Em outras versões da mesma história, Fausto, ao se encontrar com o diabo, vende sua alma "em troca de determinados bens claramente definidos e universalmente desejados: dinheiro, sexo, poder, fama e glória”. 39 . Enquanto que na versão de Goethe, Fausto tenta explicar o seu desejo para que possa ser atendido pelo diabo, porém não consegue fazê-lo com clareza e assim declara que aspira todas as coisas do mundo não somente prazeres, mas também aflições: “E o que a toda humanidade é doado, quero gozar no próprio Eu, a fundo”. 40

O que esse Fausto deseja para si mesmo é um processo dinâmico que incluiria toda sorte de experiências humanas, alegria e desgraça juntas, assimilando-as todas ao seu interminável

\footnotetext{
${ }^{36}$ Idem, p.7.

${ }^{37}$ Idem, p.11.

${ }^{38}$ Idem, p.12.

${ }^{39}$ Marshall Berman, Tudo que é sólido desmancha no ar: a aventura da modernidade. São Paulo, Companhia das Letras, 1987, p.41

${ }^{40}$ Johann Wolfgang Goethe, Fausto. Belo Horizonte, Editora Itatiaia, 1987, p. 85.
} 
crescimento interior; até mesmo a destruição do próprio eu seria parte integrante do seu desenvolvimento. ${ }^{41}$

Quando Mefisto se dirige a Fausto, na peça de Vianna, como: "Meu eterno Don João Fausto” é possível enxergar referência ao personagem de Molière. Nesta alusão podemos talvez compreender que o Artista criado por Renato Vianna, obcecado pela estátua de pedra, é um Fausto e é também uma espécie de Don Juan, ou melhor, que os dois personagens, ao carregarem consigo angústias semelhantes, podem ser vistos lado a lado.

Don Juan mostra a alucinada procura de um homem que só repousará na morte, porque a vertigem terrena nunca lhe permitiu encontrar a própria unidade. As múltiplas mulheres representam o desespero de não ter descoberto a única, bem como a blasfêmia, o fardo por não se ter conseguido entregar à religião. ${ }^{42}$

A sobreposição de personagens sugere que o entendimento do primeiro torna-se mais intenso à luz das características do segundo. Como se o diálogo entre os dois desvendasse aspectos antes não reconhecidos. Ao sobrepor os personagens o autor aponta para o seu processo de elaboração artística e nos convida a especular acerca da mesma. Além disso, no processo de construção da obra explicitado, Vianna acabava por realizar um procedimento marcadamente moderno.

Cabe também notar que quando as referências a outras obras são feitas, desfaz-se a continuidade do drama rigoroso, que servia de modelo para as comédias dramáticas e de parâmetro para os críticos teatrais do período. E mais ainda, quando as referências são sugeridas e, em seguida, abandonadas, já que as escolhas dos personagens são diversas daquelas encontradas na obras originais - como, por exemplo, o dinheiro no lugar da alma, o cheque no lugar do sangue -, evidencia-se que se trata de outra história, de outras personagens, desfaz-se o sentido trágico do texto, a linearidade dramática da trama se vê destruída e, principalmente, revela-se o autor que existe por trás da história.

O segundo ato intitula-se "Núpcias de Tântalo”, e mostra Eduardo, que aguarda ansiosamente a chegada de Ilda, a mulher amada, espalhando pétalas de rosas pela casa.

\footnotetext{
${ }^{41}$ Marshall Berman, obra citada, p. 41.

${ }^{42}$ Sábato Magaldi, O texto no teatro, São Paulo, Perspectiva/EDUSP, 1989, p.122.
} 
Algum tempo se passou desde a primeira cena. Eduardo conheceu Ilda há alguns dias quando passeava pelas ruas, o seu rosto, segundo o artista, é o mesmo da estátua viva que apareceu em seu sonho após a aparição de Mefisto. Desde então, os dois trocam cartas de amor, às escondidas, já que a moça é casada. Essa será a primeira noite em que estarão a sós.

A primeira parte do segundo ato desenvolve-se, portanto, de maneira leve e até cômica. Como um jovem desesperado de amor, Eduardo pede que Antonio repita diversas vezes cada detalhe do encontro que teve com Ilda, quando foi lhe entregar a última carta do patrão.

Eduardo - Dize-me, repete-me pela última vez, ela falou-te?

Antonio - Sorriu-me!

Eduardo - Sorriu-te! Sorriu-te? E não caíste logo fulminado de luz?

Antonio - É linda, meu senhor, é linda! (...)

Eduardo - Que mais?

Antonio - Nada, meu senhor!

Eduardo - Oh! Que memória infame, a tua! Pois não me disseste...

Antonio - Ah sim... Deu-me a mão a apertar!

Eduardo - A sua mão de fada. (tomando a mão direita de Antônio) A sua linda mão de pluma! (como que se enleva na contemplação da mão do escudeiro) A sua linda mão de madona... (abstraído, beija a mão de Antônio). ${ }^{43}$

Diferentemente do primeiro ato, o artista, que não mais é denominado através das rubricas como Fausto e sim como Eduardo, coloca-se de maneira juvenil, bem-humorada, como quem se diverte com o risco de amar uma mulher casada e marcar encontros na calada da noite. No meio do frenesi de espera, retorna Mefisto, criatura diabólica que somente Eduardo consegue enxergar; a atmosfera suave da cena é deixada de lado, semelhante a um pesadelo que invade a realidade. A cena é de novo interrompida, desta vez com a chegada do escudeiro que entra anunciando a chegada de Ilda.

Antonio - Ei-la meu senhor!

\footnotetext{
${ }^{43}$ Renato Vianna, obra citada, p.15.
} 
Eduardo fica chumbado no chão. Rapidamente Mefisto desaparece por trás do reposteiro. Entra uma mulher envolta em uma capa da cabeça aos pés. O Escudeiro desaparece também. E só então Eduardo se aproxima, como que despertando à realidade. ${ }^{44}$

Como no mito de Tântalo, ao qual o título do segundo ato se refere, que ao se aproximar das árvores frutíferas vê as frutas apodrecerem e não pode por isso desfrutá-las, Eduardo também não consegue se aproximar de Ilda sem que antes aquele momento de paixão eufórica se transforme em um momento de extrema tristeza. O comportamento de Eduardo, neste segundo ato, se desenvolve com a mesma diversidade de referências reveladas pelo texto, o que tanto incomodou os críticos de seu tempo.

Diante de sua amada, que surge amedrontada pela culpa da traição, Eduardo, primeiramente, age como um amante típico dos dramas românticos declarando: "com que fundamento moral de justiça, condenam os homens o nosso amor?” ${ }^{45}$ Em seguida, lembrase do sonho com Mefisto, conta tudo como se passou a Ilda, e passa a sofrer como o Doutor Fausto sofre na obra de Goethe, após descobrir todo o mal que fez à jovem Margarida. Assim, implora que Ilda vá embora e salve a sua alma, pois acredita que "só se vive quando se tem a consciência tranqüila”. ${ }^{46}$ Ilda escolhe ficar, os dois se beijam e Eduardo em seu desdobramento febril, quase alucinado, indica que os dois agora se encontram "a borda de um abismo". ${ }^{47} \mathrm{O}$ ato termina com Eduardo seguindo para o quarto ao encontro de Ilda.

No terceiro e último ato, que aparece com o título "Fausto no inferno", a luz vermelha incide sobre o palco desde a primeira cena. O espaço está desarrumado, com muitos livros sobre as mesas. Eduardo está "subterraneamente perdido no abismo do pensamento". ${ }^{48}$ No pedestal onde se encontrava a convidada de pedra, agora se vê um esqueleto. Mefisto também aparece em cena. Os dois ora dialogam e ora pronunciam os próprios pensamentos em voz alta, como se o discurso brotasse apenas de um personagem ou como um monólogo dividido em duas partes. Através das rubricas notamos que a partir de então, mesmo quando conversa com Mefisto, o nome de Eduardo permanece o mesmo.

\footnotetext{
${ }^{44}$ Idem, p.20.

${ }^{45}$ Idem, p.22.

${ }^{46}$ Idem, p.26.

${ }^{47}$ Idem, p.27

${ }^{48}$ Idem, p. 29.
} 
Eduardo lê, Mefisto fala, Eduardo pensa e escreve. As rubricas esclarecem o quanto um representa o reflexo do outro: "Eduardo repensa emudecido. O seu mutismo é o próprio raciocínio infernal de Mefisto"49, ou ainda "Eduardo, enquanto fala Mefisto, como que se ouve a si próprio, a voz da sua consciências em solilóquio”. ${ }^{50} \mathrm{O}$ artista já não mais se impressiona com a figura do diabo. Porém, os dois dividem os mesmos pensamentos, as mesmas convicções.

Surge Ilda. Diante dela Eduardo parece temeroso. Ele a trata como alguém que amou, mas que já não mais existe. O sofrimento de Eduardo é também intensamente representado pela falta de ligação que estabelece com a realidade. Por fim, e de maneira trágica, Eduardo aponta um revólver para própria testa e Mefisto, que a tudo assiste de maneira impávida, deseja-lhe boa viagem. Eduardo atira não em sua direção, e sim na direção de Mefisto, porém quem cai morto é mesmo o próprio Eduardo.

\section{A encenação.}

Renato Vianna, em 1922, já era um autor com certo prestígio no meio teatral, afinal havia encenado três peças com a Companhia Dramática Nacional, duas delas com a presença de Itália Fausta, e outra, Luciano, o encantador, havia sido montada por Leopoldo Fróes. Porém, em 1922, ao colocar em cena o texto A última encarnação de Fausto, Renato Vianna dava um passo mais arriscado, colocando-se à prova e portanto à mercê das vaias. Ao montar o seu texto acompanhado por outra poética, que surgia através da iluminação, do som e da interpretação dos atores, a montagem de A última encarnação de Fausto apresenta inovações notáveis.

Quem, neste país onde só agora o teatro encontra eco, teve a audácia, a esplêndida coragem de introduzir na nossa cena silêncios, valorizando-os com gestos? Quem procurou inicialmente sublinhando o drama de situações e palavras, usar de recursos luminosos e sonoros? (...) Quem, quando não se falava entre nós no subconsciente e no inconsciente expostos em cena, já deles se preocupava, às vezes tropegamente, mas corajosamente, fazendo-se ao mesmo tempo manipulador do abstrato e do real? (...) Esse alguém a quem se deve tanto é o Sr. Renato Vianna. ${ }^{51}$

\footnotetext{
${ }^{49}$ Idem, p.30.

${ }^{50}$ Idem, p.30.

${ }^{51}$ Paschoal Carlos Magno, “O guerreiro da quimera”. In: Revista Eletrônica Teatral Anta Profana, 2008.
} 
Num contexto em que a luz do espetáculo se propunha a simplesmente iluminar o palco deixando visíveis as diversas cenas, normalmente utilizando-se de gambiarras e ribalta, a iluminação idealizada por Renato Vianna devia mesmo gerar espanto entre os críticos e espectadores. Todo o espetáculo é marcado por um jogo de luz repleto de informações adicionais à cena. O luar, desenhado a partir da luz proveniente de fora da cena, marca a cena inicial e também o encontro dos amantes no segundo ato, sublinhando um ambiente de sonho. As rubricas, por sua vez, que se dirigiam aos atores e demais participantes do espetáculo, a todo o momento enfatizavam não somente aspectos da iluminação, como também o caráter que deviam possuir:

O artista depois de um momento, empurra a otomana para defronte da "terrasse”. Fecha a luz do abat-jour. O luar expande-se por toda a cena, como uma forte projeção de holofote. Um luar mágico, fantástico, absolutamente teatral. ${ }^{52}$

Assim como a luz, a música composta por Villa Lobos tinha presença marcante, através dela eram assinalados os momentos mais densos da peça, as mudanças de atitude e os sentimentos mais íntimos dos personagens. No segundo ato, enquanto Eduardo aguarda a chegada de Ilda, "Um violino, em absoluta surdina, evocará a efusão da alma do artista”. ${ }^{33}$ A música acompanhava todas as cenas, seja em surdina, seja em movimentos fortes ou até com pausas desconcertantes acompanhadas pelo silêncio das falas. No segundo ato, Eduardo luta com Mefisto, a rubrica indica que é uma luta de morte, uma luta de titãs, acompanhando o caráter da cena surgem as indicações de mudanças de luz e de som.

Os dois homens se embaraçam no reposteiro. Eduardo, com as mãos no pescoço de Mefisto a sufocá-lo. Subitamente, ouve-se um "acordum” na orquestra, enquanto a cena fica um segundo às escuras. Ao iluminar-se de novo o studio, Eduardo prossegue ainda a luta alucinada. Com o reposteiro do fundo. Tudo fora um simples delírio... Eduardo como que despertando do delírio.

\footnotetext{
${ }^{52}$ Renato Vianna, obra citada, p.3.

${ }^{53}$ Idem, p.16.
} 
Olha, procura... Aproxima-se da mesa, enche outra vez a taça. Há um estranho, misterioso e forte ruído em todo o teatro, durante toda esta cena fantástica. ${ }^{54}$

Os atores, pode-se notar pelas rubricas e também pelas anotações registradas no texto, em cópia existente no arquivo da SBAT, possuíam uma série de movimentações, as quais não serviam apenas para mantê-los visíveis em cena, mas que exploravam o espaço e a significação da mesma. O protagonista podia não ocupar o centro do palco em momentos cruciais e, inclusive, colocar-se de maneira pouco visível, assim como o coadjuvante ficava livre para se colocar no centro da cena.

Às vezes o Escudeiro, que era figura secundária, ocupava o centro do palco, enquanto Eduardo, o protagonista, deslocava-se para áreas mais afastadas. Durante e primeira entrevista de Eduardo com Mefisto, quando o artista inicia um solilóquio, no decorrer do qual vai para o fundo e depois, frente à estátua e "de costas para o público", faz uma imprecação (Eu não quero a tua forma, mísera pedra bruta! Eu quero a tua Alma, e essa hei-de arrancart’a aos céus!”) que pela força dramática só podia ser feita no centro do palco e de frente (ou, quando muito, de perfil) para o público. $^{55}$

Pode parecer estranho que ainda no inicio do século XX a idéia de movimentação em cena sem obedecer a hierarquia de primeiros e segundos atores no centro e nas laterais do palco, ou mesmo as “costas para o público”, pudessem significar uma desordem aos olhos do público. “As costas para o público”, por exemplo, foi amplamente discutida nos tempos do Ginásio Dramático, nos anos 1860, no momento que a estética realista aportava nos palcos brasileiros através dos espetáculos apresentados no Ginásio Dramático. “A idéia de que o ator devia representar como se não estivesse diante de espectadores, fundamental para a estética realista, foi quase sempre levada em conta pelos artistas do Ginásio”. ${ }^{56}$ Porém eram alterações deste tipo, algumas já conhecidas, mas que pouco utilizadas ainda pareciam estranhas, e outras efetivamente novas, que avançavam ao encontro de uma linguagem moderna, livre de regras pré-estabelecidas, que pareciam incomodar os críticos, já que os desafiavam a uma nova leitura da cena.

\footnotetext{
${ }^{54}$ Idem, p.28.

55 Sebastião Milaré, obra citada, p.67.

56 João Roberto Faria, O teatro realista no Brasil: 1855-1865. São Paulo, Perspectiva/EDUSP, 1993, p.121.
} 
Um recuo?...Um avanço?... E a dúvida permaneceu, sem que pudéssemos explicar a nós mesmos, se com o seu último trabalho - "A última encarnação de Fausto" - que serviu sábado no São Pedro, a estréia da "Batalha da Quimera", pretendeu o Sr. Renato Vianna tornar ao teatro da fantasia dos antigos ou lançar-se em vôo largo, a um futurismo que, pode ser, em quadra ainda longínqua, represente perfeição. ${ }^{57}$

Através de procedimentos como esses Renato Vianna realizava "um ato de rebeldia imperdoável, uma bofetada na platéia” ${ }^{58}$ Ao retirar os atores principais do centro do palco, retirava-se também o núcleo do drama do centro das atenções, a história sem linearidade perfeita ficava ainda mais desalinhada. Um desafio ao entendimento dos espectadores que não podiam mais acompanhar a história através de códigos antigos, a montagem assim realizada quebrava expectativas conhecidas de leitura do espetáculo e como "obra opaca" acabava por sugerir uma nova apreensão da realidade.

O silêncio dos atores foi também elemento marcante nesta montagem. Os críticos se referiam a eles como pausas sem sentido, enormes cenas mudas, longas meditações. Porém as pausas entre os diálogos, a movimentações sem falas, a busca de um pensamento por detrás da fala significavam experimentações em torno do trabalho do ator, as quais, desde o final do século XIX, eram princípios fundamentais em pesquisas teatrais.

O trabalho do Sr. Renato Vianna é um extenso volume de rubricas. No $3^{\circ}$ ato há várias cenas mudas intermináveis; satanás passeia pela cena durante longo tempo antes de tomar posição para dizer alguma tolice com ares de sentença filosófica; logo na primeira cena os movimentos de dois personagens parece uma representação cinematográfica, tornando o espetáculo massador e assim por diante. ${ }^{59}$

Podemos imaginar que devia ser um desafio também para os atores, um trabalho de desautomatização, pois sem o costume de trabalhar o silêncio dos personagens, de reconhecer o pensamento que corre por baixo de cada fala, precisavam trabalhar em dobro. No segundo ato, quando Eduardo espalha flores pelo espaço a fim de receber a visita de sua

\footnotetext{
${ }^{57}$ Otávio Quintiliano, “Batalha da Quimera”, O Jornal, 19/12/1922.

${ }^{58}$ Sebastião Milaré, obra citada, p.67.

${ }^{59}$ Oscar Guanabarino, “Batalha da Quimera”, Jornal do Commércio, 17/12/1922.
} 
amada, o que poderia significar somente um momento de prazer e êxtase, aparece, contraditoriamente, marcado pela tristeza. A rubrica indica o estado de ânimo que o ator deve conceder ao personagem:

Eduardo tem feito estas cenas sem exaltação, mas com um desalento que ele procura disfarçar de leve ironia e fingido júbilo. ${ }^{60}$

Através do silêncio o autor sinalizava para a subjetividade das personagens, para o conflito entre o que era dito e o que era apenas pensado. O silêncio, mesmo que corroborando para a dramaticidade da cena, interrompia o fluxo do diálogo. Nas rubricas podemos encontrar pistas da intenção do autor que pretende explorar a ação interna dos personagens.

Renato Vianna conhecia e citava em seus trabalhos, além dos estudos recentes de Freud acerca do inconsciente, as investigações em torno dos estudos de criação de personagem que, desde o final do século XIX, eram patentes na arte teatral, principalmente através das pesquisas desenvolvidas por Constantin Stanislaviski no Teatro de Arte de Moscou. Para Stanislavski a ação interna dos personagens de uma fábula devia estar em primeiro lugar, devia ser explorada e compreendida pelos atores. O ator e diretor russo, como um pioneiro da encenação moderna, trazia para a cena "o rio que corre por baixo do texto” e inaugurava uma nova concepção para o trabalho dos intérpretes.

A montagem esteve em cartaz no Teatro São Pedro, do Rio de Janeiro, de 15 a 17 de dezembro de 1922. Mesmo sendo considerada um fracasso de bilheteria e retirada de cena rapidamente, a peça de Renato Vianna recebeu uma quantidade razoável de artigos, o que significa que ao menos foi capaz de gerar uma discussão no meio teatral, o que não era pouco já que o desagrado fora tão intenso.

\section{O atendimento ou não ao gosto do espectador.}

A baixa qualidade artística dos espetáculos como conseqüência da falta de exigência do público é tema recorrente na história do teatro brasileiro. O teatro não evolui, diz-se, por causa do público, os autores não podem colocar bons espetáculos em cena por conta da

\footnotetext{
${ }^{60}$ Renato Vianna, obra citada, p.14.
} 
falta de interesse. Os espectadores, por sua vez, somente têm como oferta este tipo de espetáculo e por isso não podem fazer escolhas. Como referência importante dessa discussão, podemos lembrar as cartas de Artur Azevedo publicadas na imprensa, nas quais explicava os empecilhos encontrados pelos dramaturgos do país. Quando querem fazer um "bom teatro" encontram pela frente, através de seus interlocutores, censuras e injustiças, porém ao enveredarem para a "bambochata" não faltam elogios e festas. Azevedo reclamava da recepção negativa que as suas “comédias literárias” recebiam não somente do público, mas da crítica, inclusive dos seus colegas de profissão. Em carta a Coelho Neto, publicada no jornal A notícia, em 1898, Azevedo, após ser acusado por suas concessões, aconselhava ironicamente que o autor se transformasse em empresário para que algo pudesse ser feito em prol da qualidade artística do teatro nacional.

Também eu peço-te um bom mouvement: faze-te empresário. Faze-te empresário, e eu serei coerente, escrevendo comédias literárias para o teu teatro. Mas vê lá: se ficares a pão e laranja, não te queixes de mim, mas de ti... Não te metesses a redentor! $!^{61}$

Ao colocarem em pauta a questão da qualidade artística e o desenvolvimento da aptidão da platéia, dramaturgos e jornalistas discutiam fatos de extrema importância para o reconhecimento do papel fundamental da arte na sociedade, porém ao culparem o público e, no caso dos dramaturgos, ao não se disporem a enfrentar o desagrado dos espectadores, a discussão perdia a eficácia. A arte se rendia frente a um teatro de mero entretenimento, alegando-se que não havia espectadores devidamente formados. Segundo os comentaristas, o público deveria ser exigente e formado de antemão, não se pensava, contudo, que a dinamização do diálogo entre arte e sociedade precisa se dar na própria sala de espetáculos, de modo que artistas e espectadores possam colaborar na discussão de suas tensões mais agudas.

Antes mesmo da estréia de A última encarnação de Fausto, Renato Vianna avisou que não respeitaria normas, que faria "teatro a seu modo",62, sem "preocupações de regras, de técnica, de ação"63 - os críticos citam, de uma maneira ou de outra, palavras de Vianna a

\footnotetext{
${ }^{61}$ Artur Azevedo, “Carta a Coelho Neto”. In: João Roberto Faria, obra citada, 2001, p.604.

${ }^{62}$ Otávio Quintiliano, “Batalha da Quimera”. O Jornal, 19/12/1922.

${ }^{63}$ Crítica não assinada, “Batalha da Quimera”. O Paiz, 17/12/1922.
} 
esse respeito no início de suas apreciações sobre o espetáculo. Através de declarações como essas o autor prevenia também, ainda que subliminarmente, que não tinha em vista com esse espetáculo o agrado certo do público ou da crítica. Dessa maneira, tocava tanto na discussão apontada por Azevedo e Coelho Neto anos antes, quanto se opunha ao horizonte de expectativas de seu tempo, negando o oferecimento de algo de fácil assimilação.

Através das entrevistas feitas pelo jornalista Daniel Caetano, no Rio de Janeiro, no ano de 1946, com os principais artistas empresários, autores e críticos da época, podemos notar o desdobramento da mesma questão discutida desde o final do século XIX. A questão aparecia então nos seguintes termos: os artistas devem ou não se submeter ao gosto do público? Entre os entrevistados estavam, além de Renato Vianna, Jaime Costa, Bibi Ferreira, Joraci Camargo, Gastão Tojeiro, Mário Nunes, Miroel Silveira, R. Magalhães Jr. e Nelson Rodrigues.

O jornalista apresenta Renato Vianna com entusiasmo, reconhece as suas atividades como pioneiras, assinala que o autor é no teatro nacional "um caso de incompreensão" e se pergunta como pode o seu trabalho gozar de tão pouca repercussão. Daniel Caetano inicia a entrevista perguntando acerca do desenvolvimento do teatro entre nós, ao que Vianna responde com otimismo, lembrando os novos autores que estão surgindo na cena e a forma séria com a qual encaram o assunto teatro brasileiro. Quando indagado sobre a importância de agradar o público, assinala que a obra de arte é capaz de suscitar o gosto da platéia e quando o jornalista afirma que sem público não pode viver o teatro o escritor dispara:

Sim. Não há dúvida. Mas a obra de arte fica prejudicada quando o autor pensa na bilheteria. As duas coisas são inconciliáveis. Infelizmente não deixo de reconhecer a preponderância do problema econômico nesse particular. Prefiro ganhar pouco, porém ganhar de acordo com a minha consciência. Comigo, a arte primeiro. Depois, a bilheteria. ${ }^{64}$

A entrevista foi feita em 1946, mais de vinte anos já havia se passado desde $A$ última encarnação de Fausto, Renato Vianna estava então com 52 anos e já carregava em sua bagagem uma série de tentativas e realizações. Depois do grupo da Quimera, formou ainda três outras companhias, Colméia, em 1924, Caverna Mágica, em 1928 e o Teatro de Arte, em 1932. Em 1934, inaugurou com apoio do governo o Teatro-Escola - que

\footnotetext{
${ }^{64}$ Idem, p.130.
} 
redundaria na Escola Dramática do Rio Grande do Sul e no Teatro Anchieta grupo teatral formado com atores egressos da Escola Dramática. No final da entrevista, Renato Vianna declara que pretendia, a partir de então, se recolher para um trabalho de gabinete e o jornalista conclui o artigo lamentando a decisão e o afastamento de Vianna dos rumos da cena.

Outros autores entrevistados, tais como R. Magalhães Jr, no entanto, ao se referir ao autor de A última encarnação de Fausto, trata de seu trabalho com certo descaso.

O teatro de ... é muito chato. O público foge daquele repertório como o táxi, na Avenida, à tarde, foge da gente. Mas o seu ... acha que o seu público é burro, não compreende a sua obra. Por isso o seu ..., o sabido, tem o seu teatro às moscas. ${ }^{65}$

No lugar do nome de Renato Viana apareciam reticências, pois o entrevistador acreditou que assim preferiria o entrevistado. Porém, R. Magalhães Jr. pediu ao jornalista que divulgasse o nome ocultado, o que foi feito em nota publicada posteriormente. Sobre o público, o autor de A família Lero-Lero, acrescentou:

Não se pode exigir muito da nossa platéia. Não adianta levar para a cena o que o público não quer ver. A educação das platéias é feita nas escolas. A bilheteria testemunha o gosto do público melhor do que ninguém. ${ }^{66}$

Na ocasião, parecia totalmente extravagante que um autor não escrevesse pensando na bilheteria, que não produzisse de olho no lucro, que não agradasse o público com peças de aceitação fácil. As inovações de cunho moderno feitas por Vianna, relacionadas com a formação de um grupo teatral, a opção por abrir mão do esquema lucrativo de estrelas, assim como colocar o ideal artístico na frente da bilheteria, eram motivos de censura e graça. Em artigo publicado posteriormente, em junho de 1953, o mesmo R. Magalhães Jr, no entanto, declarou:

\footnotetext{
${ }^{65}$ Victor Hugo Adler Pereira, A musa carrancuda: teatro e poder no Estado Novo. Rio de Janeiro, Editora Fundação Getúlio Vargas, 1998, p.139.

${ }^{66}$ Idem, p.139.
} 
Foi Renato Vianna um antecipador de Paschoal Carlos Magno e do seu Teatro do Estudante, de Valdemar de Oliveira e do Teatro Amadores de Pernambuco, como dos Comediantes e o TBC de São Paulo. A sua luta não deixou de ter nestes vinte anos uma grande repercussão nacional e ele próprio andou acordando vocações teatrais e insuflando movimentos da mesma natureza em vários Estados. Ajudou a amanhar o terreno em que outros estão plantando. ${ }^{67}$

Podemos talvez deduzir, através das falas de R. Magalhães Jr., que no calor dos acontecimentos a postura de Vianna incomodava, porém, anos depois, era possível encontrar algum pioneirismo em suas atitudes.

No mesmo conjunto, aparece entrevista concedida por Nelson Rodrigues, que na ocasião tinha a sua peça Álbum de Família proibida pela polícia, note-se que a esta altura dos acontecimentos o texto Vestido de Noiva já havia sido encenado pelo grupo Os Comediantes. O jornalista também questiona o dramaturgo acerca da relação entre criação artística e público, e Nelson, ao ser questionado sobre bilheteria, responde: "É com o bilheteiro. O autor que pensa no público mata a obra de arte”. ${ }^{6}$

Neste conjunto de entrevistas, Renato Vianna, Nelson Rodrigues (e também Brutus Pedreira, fundador de Os Comediantes), aparecem como exceções na certeza de que o teatro devia primeiramente gerar lucro e para isso tornava-se necessário adequar o repertório a um gosto presumivelmente conhecido de espectadores pouco exigentes. Com essa postura conseguiam se desvencilhar daquela discussão sem fim, tomando para si a tarefa de enfrentar o possível desagrado dos espectadores e construir uma obra que eles próprios admirassem, cada um a seu jeito, com características e posturas diversas.

\footnotetext{
${ }^{67}$ R. Magalhães Jr., apud Sebastião Milaré, obra citada, p.7.

${ }^{68}$ Victor Hugo Adler Pereira, obra citada, p.153.
} 


\section{Capítulo 4}

\section{A experiência moderna em Flávio de Carvalho.}

\section{Os manifestos arquitetônicos.}

Caminhando propositalmente na contramão, portando provocativamente seu chapéu na cabeça, no meio dos seguidores da procissão artística do período, que carregavam respeitosamente nos ombros a mortalha de uma estética decadente, surge a figura de Flávio de Carvalho, propositor de experimentações marcadas pela recusa a qualquer dogma estabelecido. A sua conhecida virulência ante a hipocrisia, e a voracidade na deglutição e devolução exasperada e dissonante de todo gesto que lhe cruzava o percurso, lhe valeram a denominação por Oswald de Andrade de “o antropófago ideal”.

Em várias de suas experiências cênicas usava o próprio corpo como objeto, atuava como um performer, que, partindo de elementos da própria vida, cria eventos artísticos, atuação que o lançará ao encontro dos embates típicos da arte contemporânea. Desejava uma nova ordem para a organização do mundo, libertando-o das amarras do cotidiano e deixava tal premissa patente, tanto em sua atuação como artista, quanto como arquiteto e engenheiro.

Muitos dos projetos arquitetônicos de Flávio de Carvalho não foram construídos no período. A concretização dessas obras, contudo, se deu na inscrição em concursos públicos em que suas propostas visuais e urbanísticas foram amplamente discutidas, ocasionando debates acalorados. Foram diversos os concursos de arquitetura de que o artista participou, no Brasil e no exterior. Entre os mais conhecidos estão os projetos idealizados para o Palácio do Governo de São Paulo (1927), para o Farol de Colombo, na República Dominicana (1928), para a Universidade de Minas Gerais (1928) e para o Palácio do Congresso do Estado de São Paulo (1929). As suas propostas foram recusadas inúmeras vezes, o que não prejudicou o seu intuito de, ao participar de concursos oficiais, apontados como reduto do conservadorismo, promover a discussão acerca das tendências modernas na 
arquitetura brasileira. "Sua atuação neste primeiro momento foi vista como a do demolidor dos preceitos estabelecidos, que faz de cada projeto um manifesto". 1

Estes projetos-manifestos se desdobravam através dos debates travados entre os jornalistas e escritores do período. Os projetos inscritos para a edificação do Palácio do Governo de São Paulo², por exemplo, colocados em exposição no Teatro Municipal, ocasionaram a publicação de opiniões diversas na imprensa do período. No Diário da Noite, de 4 de fevereiro daquele ano, aparecia, em manchete de primeira página, nota afirmando que o projeto de Flávio de Carvalho era "uma granada que se lança sobre a rotina”. ${ }^{3}$ Mário de Andrade, escrevendo para o Diário Nacional, dedicou três artigos ao concurso nos quais deixava clara sua simpatia pelo projeto de Flávio e adiantava: “o único que honra o concurso". ${ }^{4}$

No esboço para o Farol de Colombo ${ }^{5}$, a ser construído na República Dominicana, Flávio de Carvalho de novo não estava entre os premiados, porém sua participação mereceu destaque entre os organizadores do concurso. No álbum editado para a convocação da segunda etapa, reproduziram o seu projeto em cores, dedicando-lhe três páginas. O arquiteto paulista teve, assim, mesmo com a proposta desclassificada, uma repercussão significativa de suas idéias, fato que garantiu a atenção da imprensa européia e norteamericana $^{6}$, e que possibilitou que se travassem relações entre seus preceitos estéticos e as invenções modernistas em curso no Brasil.

Seu projeto para o Farol de Colombo, que combinava a linguagem moderna à herança das antigas culturas e civilizações americanas, parecia ser a realização na arquitetura do ideário do grupo da Antropofagia. ${ }^{7}$

\footnotetext{
${ }^{1}$ Rui Moreira Leite, Flávio de Carvalho: entre a experiência e a experimentação. Tese de doutorado, Departamento de Artes Plásticas da Escola de Comunicações e Artes da Universidade de São Paulo, 1994, p.18.

${ }^{2}$ Ver foto na página seguinte.

${ }^{3}$ Diário da Noite, apud Sangirardi Júnior, Flávio de Carvalho: o revolucionário romântico. Rio de Janeiro, Philobiblion, 1985, p.21.

${ }^{4}$ Mário de Andrade, apud Rui Moreira Leite, obra citada, p.11.

${ }^{5}$ Ver foto na página seguinte.

${ }^{6}$ Rui Moreira Leite, obra citada, p.13.

${ }^{7}$ Idem, p.18.
} 


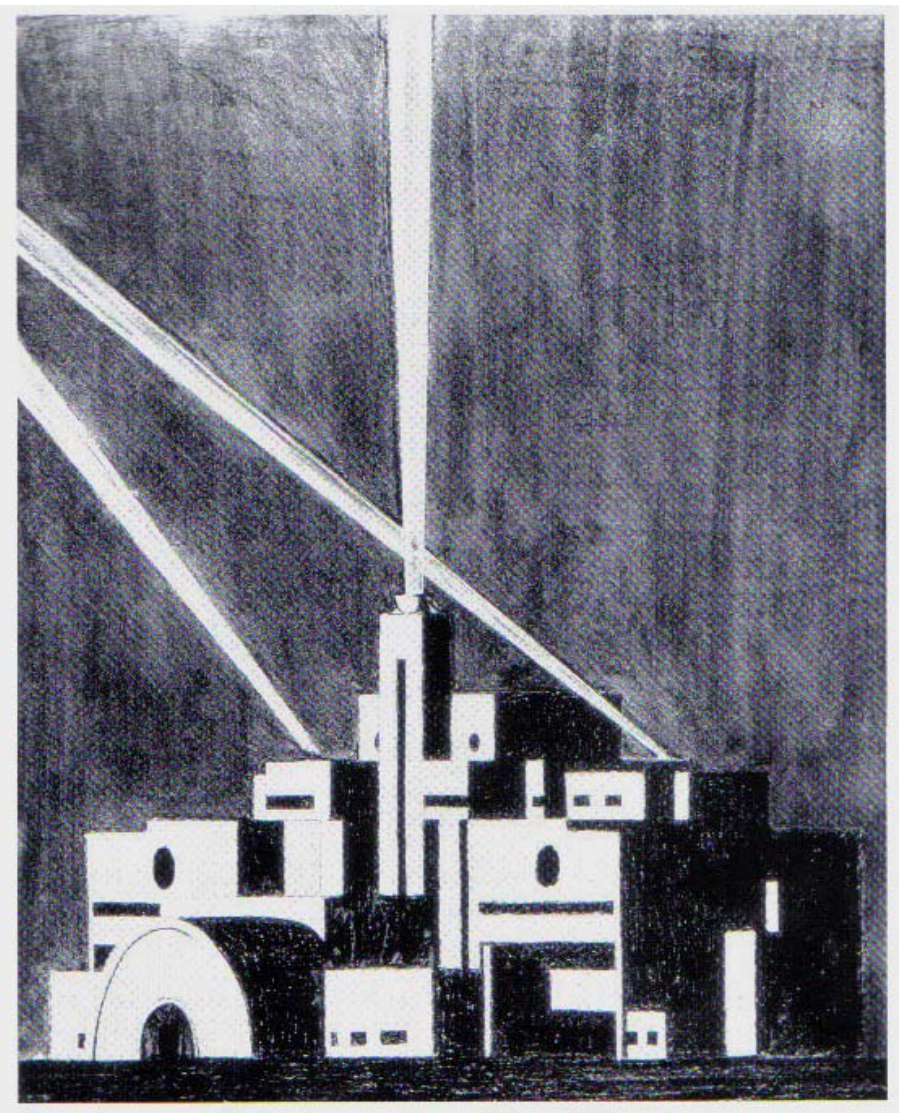

Flávio de Carvalho

Eficácia 1927

Projeto para o Palácio do

Governo do Estado de São Paulo 


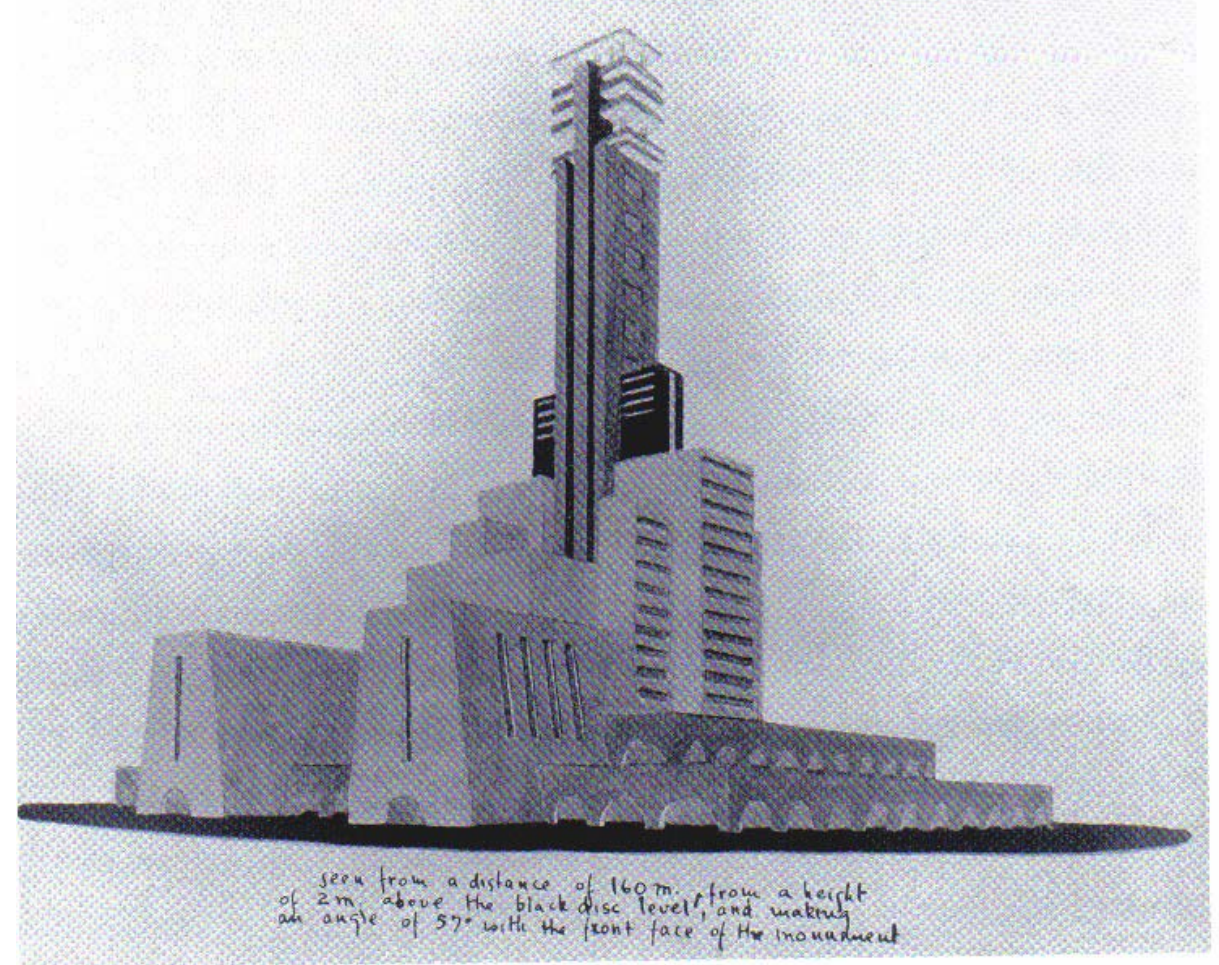

Flávio de Carvalho

1928

Projeto para o Farol de Colombo 
As invenções propostas pelo arquiteto antropófago eram explicadas, na maioria das vezes, através de textos que acompanhavam os desenhos. No projeto para o Farol, assim como no dedicado ao Palácio do Governo, surgia a integração entre pintura e arquitetura: no interior do farol, Flávio previa uma combinação de painéis modernos com imagens das mitologias pré-colombianas. Acerca desta combinação, o autor explicava:

Hoje a arquitetura pode se dividir em duas partes. A forma, que proporciona o bem-estar físico e moral. E a cor, que dá o bem estar intelectual. O bem estar físico está ao alcance de todo o engenheiro que estuda o seu mister. O bem estar intelectual cai no domínio da psicanálise. É preciso que o arquiteto seja também um artista, e não única e simplesmente um engenheiro que traça, a régua e compasso, linhas retas e linhas curvas. ${ }^{8}$

Em Belo Horizonte, quando teve o seu projeto para a Universidade de Minas Gerais recusado, Carlos Drumonnd de Andrade também entrou no debate. Sob o pseudônimo de Antonio Crispim, no Diário de Minas, o poeta apontou, primeiramente, o que para ele representavam os defeitos do projeto, “o excesso de lógica fria, de raciocínio puro” e, posteriormente, sobre a sua desclassificação, explicou o que lhe parecia mais importante:

O que mais me encanta nisso tudo porém, é a beleza calada do gesto de Eficácia [pseudônimo de Flávio de Carvalho]. Ele concorreu sabendo que não venceria. Concorreu com um sorriso que muitos pensam de desdém, mas que eu prefiro acreditar seja um sorriso de inteligência. ${ }^{9}$

O sorriso que Drummond enxergou em Flávio de Carvalho, marcado por boa dose da ironia que lhe era peculiar, estava presente em grande parte de suas atividades. Os seus projetos arquitetônicos, e também artísticos, eram como manifestos repletos de "segundas intenções”, que pretendiam não somente colocar-se como projetos, mas instigar a desconstrução de parâmetros endurecidos de análise do homem com relação ao mundo ao seu redor. Cada projeto propunha, podemos dizer, uma experiência estética calcada na mudança de ponto de vista, na renovação de conceitos. Era, por isso mesmo, um autor que

\footnotetext{
${ }^{8}$ Flávio de Carvalho, apud Rui Moreira Leite, obra citada, p.17.

${ }^{9}$ Carlos Drummond de Andrade, apud Rui Moreira Leite, obra citada, p.15.
} 
se colocava como ponta de lança de um movimento artístico que se efetivava nas entrelinhas, nos recantos menos óbvios, como projeto recusado.

Os únicos projetos arquitetônicos idealizados por Flávio de Carvalho e construídos foram o conjunto de casas na Alameda Lorena (1938), no bairro Jardim Paulista, na cidade de São Paulo, e a casa da Fazenda da Capuava (1938), em Valinhos, São Paulo; os dois custeados por ele próprio. As casas da Alameda Lorena representavam uma “reinterpretação da idéia de vila” e foram tremendamente criticadas na época de sua construção. Além de outras novidades, as dezessete casas eram alugadas e acompanhadas por um folheto informativo sobre como deveriam ser usadas.

Nesse impresso esclarecia que o aro do guarda-sol do solarium servia para a colocação de cortinas de lona ou para pendurar gaiolas com pássaros ou vasos de flores, a maneira correta de abrir as torneiras que funcionavam com pinos de pressão, como obter a ventilação desejada e como usar os ferros da cortina colocados no meio da sala para dividi-la em duas. Havia ainda espaço para observar que as cortinas deviam ser duplas, claras na face exterior e escuras no interior, e que os móveis deviam ocupar pouco espaço, o que era mais estético, confortável e higiênico. ${ }^{10}$

Já o projeto para a Fazenda da Capuava seguiu, segundo Flávio de Carvalho, “um norteamento exclusivamente poético". ${ }^{11}$ Sobre as disposições internas e sobre os elementos de decoração Flávio explicava:

As cortinas do salão foram estudadas em largura, comprimento e peso específico para que possam balançar ao vento para fora e para dentro, ao ritmo eventual da música. As aberturas foram idealizadas para fazer com que - usando a frase de Mário de Andrade - a paisagem, as nuvens, a luz e o ar entrem na casa. ${ }^{12}$

Foi nessa Fazenda que o autor pôde demonstrar como pretendia integrar o espaço a um modo de vida particular, a arquitetura moderna e o novo homem, um homem imaginado pelo autor como uma criatura sem tabus: “o homem antropofágico, quando despido de seus

\footnotetext{
${ }^{10}$ Rui Moreira Leite, obra citada, p.81.

${ }^{11}$ Rui Moreira Leite, obra citada, p.83.

${ }^{12}$ Flávio de Carvalho, apud Denise Mattar, Flávio de Carvalho: 100 anos de um revolucionário romântico. Rio de Janeiro, CCBB, 1999, p.9.
} 
tabus, assemelha-se ao homem nu". ${ }^{13}$ O local serviu como residência para o escritor até o final de sua vida, em junho de 1973.

Os estudiosos do legado arquitetônico de Flavio de Carvalho não se concentram, evidentemente, apenas nos projetos construídos. Ao contrário, os esboços recusados representam material de enorme interesse para a compreensão da aplicação dos expoentes da modernidade nos rumos das construções em nosso país. O fato de seus projetos serem constantemente recusados lhe conferiu o apelido de "o perdedor de concursos”"14 e fez com que ele próprio tirasse graça do assunto.

As minhas manifestações como arquiteto nunca foram do gosto médio e sempre foram de encontro com o geralmente aceito. (...) No início de minha carreira, a feição retrógrada dos juízes era tão pronunciada, que fui expulso de diversos concursos. Cheguei mesmo de uma feita, a mandar confeccionar um carimbo: expulso de concurso. ${ }^{15}$

Ou seja, fica claro, ao observarmos a sua trajetória, que a recusa de suas idéia não subtraiu a sua enorme influência nos rumos da arquitetura no Brasil, antes sublinhou sua audácia e seu vanguardismo. A não rendição ao gosto médio lhe possibilitou investigar concepções inéditas que demoraram algumas décadas até serem aceitas e executadas entre nós.

\section{Os enfrentamentos da arte moderna.}

Se a forma é fluída, o "sentido" ainda o é mais...

Nietzsche

Um ativista que propunha experiências estéticas de vanguarda em áreas diversas arquitetura, pintura e moda -, e que buscava conceber um teatro capaz de dialogar de maneira incisiva com a sociedade, assim talvez possamos definir Flávio de Carvalho. A função da arte para o encenador paulista, contudo, não é a de definir ou impor critérios prévios de interpretação, mas a de fomentar a atitude criativa do público, estimulando a formulação de padrões próprios de análise. Ou seja, é tarefa da arte "acordar as partes

\footnotetext{
${ }^{13}$ Flávio de Carvalho, apud Denise Mattar, obra citada, p.80.

${ }^{14}$ Sangirardi Júnior, obra citada, p.26.

${ }^{15}$ Flávio de Carvalho, “Entrevista a Silveira Peixoto”. In: Rui Moreira Leite, obra citada, p.148.
} 
adormecidas do espectador. É uma função sugestiva, e deve ser sugestiva antes de ser persuasiva". 16

Quando perguntado acerca das principais influências que teve em sua formação intelectual, o artista destaca dois autores em especial: Freud, de quem ressalta "a polarização sexual de suas idéias", pois considerava "perfeitamente natural encontrar a gênese das coisas no sexo. Não devemos ao sexo o próprio fato de nossa existência?" ${ }^{17}$; e, principalmente, Nietzsche, que, segundo declara, o influenciou decisivamente.

Anos atrás, quando li Nietzche, senti-me fortemente comovido pela selvageria poética e pela profundeza da essência humana que nele se contêm. Nietzsche se tornou para mim a besta intelectualizada. Gostava e gosto imenso da estranha brutalidade que ele usa ao lidar com os bonecos bem vestidos do pensamento e do comportamento. ${ }^{18}$

A forte influência do filósofo alemão nas opções artísticas de Flávio de Carvalho pode ser imediatamente notada na concepção de $O$ bailado do deus morto, o seu mais importante espetáculo teatral - sobre o qual nos deteremos mais adiante -, em que as referências ao pensamento de Nietzsche se evidenciam tanto na idéia da morte de Deus, que aparece em diversas passagens dos escritos deste pensador, quanto na acepção dionisíaca da encenação, que pode ser associada às idéias apresentadas pelo filósofo em $A$ Origem da Tragédia. ${ }^{19}$ No entanto, a influência não se resume à afinidade com um ou outro pensamento do filósofo, pois a própria concepção de arte parece em Flávio de Carvalho intensamente marcada, como ele mesmo ressalta acima, pela poética de Nietzsche.

A filosofia de Nietzsche se dedica, em grande parte, a reacender a potência mítica do pensamento e da arte. Idéia que está intimamente relacionada com a retomada de Dioniso, divindade grega que regia os intuitos festivos dos cantos ditirâmbicos e dos primórdios da tragédia. Alegre e dançarino, Dioniso carrega consigo imagem suficientemente vigorosa para se contrapor à lamúria e à perplexidade dedicadas pela religiosidade ocidental ao crucificado. A valorização dos eventos dionisíacos se afirma,

\footnotetext{
${ }^{16}$ Flávio de Carvalho, Vanitas, São Paulo, n52, outubro de 1935. In: Mattar, obra citada, p.68.

${ }^{17}$ Flávio de Carvalho, “Entrevista a Silveira Peixoto”. In: Rui Moreira Leite, obra citada, p.149.

${ }^{18}$ Idem, p.149.

${ }^{19}$ Frederico Nietzsche, A Origem da Tragédia. Lisboa, Guimarães Editores, 1985.
} 
pois, como negação à noção de mundo terrestre concebida pelo cristianismo como um vale de lágrimas.

O caráter dionisíaco da tragédia carrega consigo, ainda, a afirmação de uma sabedoria instintiva, que se perdeu pelo ímpeto socrático de tudo transformar em pensamento abstrato, lógico, racional. O que fundamenta, em Nietzsche, a recusa a uma arte lógico-racional, plena de verdades pressupostas; verdades estas definidas à revelia dos reais sentimentos, das necessidades efetivas e da própria vontade dos homens. Esta arte racionalista, acredita-se, deve ser piedosamente destinada à salvação (arte religiosa) ou ao esclarecimento (arte burguesa) dos espectadores.

A arte precisaria, então, negando o racionalismo que se institui na tragédia grega com Sófocles, e, principalmente, com Eurípides -, fomentar nos indivíduos a vontade de poder. ${ }^{20}$ Que não deve ser compreendida como a vontade de estar no poder, ou de tomada do poder, repetindo a lógica de dominação e subjugação que ainda impera na modernidade. Esta vontade de poder, para Nietzsche, se refere à conquista do poder de criação, que se constitui em apropriar-se da capacidade de produção de conhecimentos.

Para Nietzsche, portanto - e nos parece apropriado pensar a arte de Flávio de Carvalho por este viés analítico -, o conhecimento precisa ser compreendido como criação. Ou seja, uma arte que se proponha a promover o acesso ao conhecimento precisa ser pensada como uma arte, como dizia o artista paulista, sugestiva, que fomente a própria produção de conhecimentos, e não uma arte persuasiva, destinada à mera transmissão de verdades instituídas. Ou, como dito nas palavras do próprio encenador paulista:

O contínuo teatro-cenário-assistência não é um dogma místico, criação de um decreto, como a virgindade de Maria ou a brancura do Espírito Santo, ele é um campo de expansão da imaginação do homem, ele simboliza o entusiasmo, ele é um meio sonoro, visual e psiquicamente tátil de mostrar ao mundo o quanto o homem pode raciocinar. ${ }^{21}$

Não existe, pois, um sentido original, mas interpretações sempre prontas a serem executadas e refeitas, inventadas a cada novo instante, derretendo os dogmas e sentidos preestabelecidos.

\footnotetext{
${ }^{20}$ Gilles Deleuze. Nietzsche. Lisboa, Edições 70, 2007.

${ }^{21}$ Flávio de Carvalho. “Teatro antigo e moderno”, Homem do Povo, São Paulo, 31/03/1931.
} 
Para alcançar seus intentos, importa menos para Flávio de Carvalho o tema a ser tratado, pois não está preocupado com a transmissão de valores estabelecidos, e muito mais o modo provocativo de sua abordagem. Ou seja, o fato de um espetáculo não constituir um discurso fechado, pronto para ser compreendido e aprendido, ou de não apresentar uma fábula claramente organizada, ou uma estrutura dramática rigorosa, gera controvérsias e reações entusiasmadas, e que são consideradas como extremamente produtivas pelo artista, pois, tanto o debate acerca dos sentidos plurais da obra, quanto o debate sobre a função da arte são postos em jogo. Assim, se está colocando em questão a própria tarefa da arte, e o papel do espectador, que passa a se perguntar: “isso é arte?”. E não é esta, enfim, a questão fundamental que o artista moderno quer trazer à tona? Questão que se desdobra em outras tantas: O que é arte, afinal? A que se propõe? Como pensar a atuação do espectador no evento artístico?

\section{O Teatro da Experiência.}

O bailado do deus morto fez apenas quatro apresentações na cidade de São Paulo; depois, o espetáculo foi encerrado e o teatro que a apresentou precisou fechar as portas, sendo mantido sob vigilância policial para que não retomasse suas atividades. Se fosse um projeto arquitetônico, diríamos que foi recusado. Como teatro teve, portanto, a sua atuação inibida, mas nem por isso deixou de marcar a cena teatral do país.

Na história do teatro nacional, o episódio todo tem sido apresentado como uma curiosidade marginal - o teatro do modernismo paulista que, abortado pela intervenção policial, não chegou a nascer. Existem, no entanto, elementos que permitem sugerir para o Teatro da Experiência um outro papel. $^{22}$

Assim como seus projetos de arquitetura, a repercussão e os desdobramentos do espetáculo não foram pequenos. A discussão acerca do Teatro da Experiência adentrou revistas e jornais; diversos artigos, contrários e favoráveis, foram veiculados no período. Antes mesmo de sua estréia, A Folha da Noite (14/11/1933) divulgou entrevista com Flávio de Carvalho, intitulada “O que será o Teatro da Experiência”, na qual o autor defendia o

\footnotetext{
${ }^{22}$ Rui Moreira Leite, obra citada, p.53.
} 
teor de experimentação do espaço. O Diário da Noite (13/11/1933) publicou o artigo "Que é e que pretende ser o Teatro da Experiência”. No mesmo exemplar, encontra-se artigo de Menotti del Picchia com o título “Teatro Experimental”, no qual o autor, sob o pseudônimo de Hélios, revelava total apoio e interesse pela reforma do teatro proposta pelos participantes de O bailado. Após a estréia as avaliações continuaram: O Dia (17/11/1933) e A Platéa (16/11/1933) se posicionaram contra o espetáculo, considerando-o um "atentado ao decoro público"23, um autêntico caso de polícia:

Foi esta, pelo menos, a impressão que tive, assistindo àquilo a que denominaram "O Bailado do Deus Morto” e que outra coisa não é senão uma autêntica “macumba”, apenas com o agravante de que não tem o menor respeito pela religião, pela família ou pela moral! (...)

Aquilo poderá ser muito interessante para os “artistas modernos”, poderá ser mitologia ou coisa que o valha, porém, o que não resta dúvida, é que se atenta contra a moral e se atira uma cusparada à civilização paulistana. (...)

O Código Penal pune as ofensas ao decoro público e o tal espetáculo (com certeza haverá outros) está perfeitamente enquadrado nas letras desse mesmo Código, desrespeitado por moços que se dizem de elite, por pintores, artistas, gente chic, e o que é mais estranhável, com aplausos de cavalheiros respeitáveis, que levaram suas esposas e filhas para ouvir obscenidades, ditas francamente, despudoradamente. (...)

Restará saber se é permitido, doravante, fazer coisa idêntica em outros teatros, com entradas igualmente pagas como no "Clube dos Artistas Modernos”. O Teatro da Experiência é um caso de polícia. Nada mais. $^{24}$

A previsão do crítico de que aquele tipo de espetáculo se espalharia imediatamente por outros teatros da cidade infelizmente não se confirmou. Porém, fica claro que a estréia do Teatro da Experiência não se deu sem que espectadores e jornalistas precisassem se posicionar diante do acontecimento. A cena proposta por Flávio colocaria em xeque algumas certezas acerca do que significava um espetáculo teatral e deixaria às claras as diversas posturas diante do acesso à modernidade. Na Folha da Noite foi divulgada ainda uma lista de escritores, pintores e outros artistas que, em oposição ao crítico de A Platéa,

\footnotetext{
23 “O teatro da experiência às voltas com a polícia!” O Dia, São Paulo, 17/11/1933.

${ }^{24}$ Francisco de Sá. In: Toledo, J. Flávio de Carvalho: o comedor de emoções. São Paulo, Brasiliense, Capinas, Editora da UNICAMP, 1994, p.184/185.
} 
apoiavam o espetáculo e recriminavam a ação policial de fechamento do teatro e proibição da peça. ${ }^{25}$ Entre aqueles que assinaram o manifesto estavam: Procópio Ferreira, Mário Pedrosa, Geraldo Ferraz, Caio Prado Júnior, Menotti del Picchia, Lívio Abramo, Paulo Magalhães, Joracy Camargo e Oswald de Andrade.

No artigo intitulado Teatro antigo e moderno, publicado em 31 de março de 1931, pouco antes da montagem de $O$ bailado, em O Homem do Povo - periódico dirigido por Oswald de Andrade e Patrícia Galvão, que, assim como o Teatro da Experiência, teve as suas portas fechadas após a oitava edição ${ }^{26}$-, Flávio de Carvalho discorreu sobre a distância entre a cena antiga e a moderna, avaliando que, enquanto a primeira reproduz sensações vividas, a outra se preocupa em provocar experiências novas e desconhecidas.

O homem mudou; uma parte do seu pensamento procura a análise científica das coisas, a outra parte anseia por alguma coisa que ele não sabe bem o que é, um desejo inconsciente transformado em angústia pela indecisão. ${ }^{27}$

Nos artigos escritos na década de 1930, assim como no manifesto que acompanhou o pedido de reabertura do Teatro da Experiência, o qual surgiu acompanhado de um abaixoassinado de escritores e outros espectadores a favor do espetáculo, Flávio sublinhava o propósito de tratar o teatro como um laboratório ou como um espaço de estudos.

Hoje o teatro caminha para uma nova sensibilidade, ele tornou-se mesmo um problema plástico e estético, essa sensibilidade envolve um concerto entre os sentidos, uma ligação entre um sentido e outro, por exemplo, o som da palavra tem um correspondente colorido e geométrico e vice-versa. $^{28}$

\footnotetext{
${ }^{25}$ Folha da Noite, 9/12/1933. In: Toledo, J. Flávio de Carvalho: o comedor de emoções. São Paulo, Brasiliense, Capinas, Editora da UNICAMP, 1994.

${ }^{26}$ A polícia proibiu a circulação de $O$ homem do povo após a ocorrência, nos dias 9 e 13 de abril, de graves incidentes entre Oswald, Pagu e os estudantes da Faculdade de Direito que, sentindo-se agredidos por causa de dois editoriais considerados ofensivos à Faculdade, foram para frente do jornal agredir os autores. É possível notar, através do noticiário dos outros jornais da mesma época que acompanharam o fato, a maneira como a imprensa apoiou fortemente a atitude violenta e autoritária dos estudantes de Direito. Na Folha da Noite de 19/04/1931, vê-se a seguinte manchete: "Um justo revide dos estudantes de Direito aos insultos de um antropófago". Ver: O homem do povo: coleção completa e fac-similar dos jornais escritos por Oswald de Andrade e Patrícia Galvão / Introdução : Augusto de Campos, São Paulo, Imprensa Oficial do Estado, 1984.

${ }^{27}$ Flávio de Carvalho, "Teatro antigo e moderno". O homem do Povo, São Paulo, 31/03/1931.

${ }^{28}$ Flávio de Carvalho, “O problema do teatro”. Vanitas, n 54, dezembro de 1935. In: Denise Mattar, obra citada, p.69.
} 
Com o Teatro da Experiência, Flávio de Carvalho não estava somente construindo um espetáculo com noções modernas de encenação, com elementos de iluminação e figurino inusitados. É possível notar através dessa experiência cênica, e também dos seus diversos escritos sobre arte, espalhados em revistas e jornais do período, como o artista descrevia mudanças cruciais para a práxis artística, e o modo como enxergava a chave do problema: "diante da produção contemporânea multiplica-se a densidade e complexidade da instância teórica”. ${ }^{29}$ Com a montagem de um espetáculo, a partir de então, não apenas se construiria uma cena, mas se estabeleceria uma discussão em torno do fazer teatral. A função da arte precisaria, pois, ser necessariamente colocada em jogo.

O prazer da experiência estética não surgia de maneira oposta ao raciocínio e à ação nas proposições artísticas idealizadas por Flávio de Carvalho. A proposta feita ao espectador, podia, então, ser definida nos seguintes termos: reaproximar o sentimento de prazer do ato de conhecimento, o divertimento do raciocínio. Essa compreensão de teatro, que conjugava prazer e experiência crítica, em pleno auge do nosso "teatro de entretenimento" ou do "teatro apenas para fazer rir", talvez signifique a sua maior contribuição para a modernização da cena teatral. E, também, motivo suficiente para o escândalo causado na época de sua apresentação.

Se pensarmos nos modelos defendidos para a construção do teatro em nosso país desde meados do século XIX - calcados na comédia realista francesa -, ou na repulsa causada entre alguns escritores pelo repertório moderno apresentado por Antoine, nos teatros do Rio de Janeiro, no início do século XX - “no menu dessas tranches de vie tudo é cru e duro”30 - ou, ainda, nas peças divertidas e leves que atraíam um público considerável para salas de espetáculo e que alcançavam resultados exorbitantes de bilheteria - fato que assinalava a urgência de agradar o público e não enfastiá-lo com pensamentos acerca do mundo lá fora -, podemos calcular o tamanho do problema que Flávio de Carvalho levantava ao propor um evento nos moldes do Teatro da Experiência.

\footnotetext{
${ }^{29}$ Ronaldo Brito, “O moderno e o contemporâneo”. In: Experiência crítica. Caderno de textos 1. Rio de Janeiro, FUNARTE, 1980, p.7.

${ }^{30}$ Olavo Bilac, apud João Roberto Faria, obra citada, 2001, p.676.
} 


\section{O bailado do deus morto.}

Os deuses também se decompõem! Deus está morto! Deus continua morto! E fomos nós que o matamos! Como nos consolaremos, nós, assassinos entre os assassinos! O que o mundo possuiu de mais sagrado e de mais poderoso até este dia sangrou sob a nossa faca... Quem nos limpará deste sangue? Que água poderia nos lavar? Que expiações, que jogo sagrado seremos obrigados a inventar? A grandeza deste ato é demasiado grande para nós. Não será preciso que nós próprios nos tornemos deuses para simplesmente termos o ar de ser dignos dele?

Nietzsche

A abertura do Teatro da Experiência seria feita com a encenação do texto $O$ homem e o cavalo, de Oswald de Andrade, porém, como a peça de Oswald ainda não estava terminada na data indicada para a abertura da sala, Flávio organizou O bailado do deus morto. Peça compacta em dois atos, que se referia, claramente, à Experiência $n^{\circ}$ 2, que pode ser definida como uma performance realizada pelo artista nas ruas de São Paulo, quando caminhou provocativamente no meio de uma procissão de Corpus Christi na direção contrária do fluxo de fiéis, e com um chapéu na cabeça, sendo perseguido e quase linchado pela multidão. Em ambas as experimentações - $O$ bailado e Experiência $n^{o} 2$-, ainda que de modo bastante distinto, o encenador coloca em questão a perplexidade de uma multidão de homens piedosamente postada diante da imagem de um deus morto.

O bailado não representava a esfera privada da família brasileira, nem interesses individuais. Como afirmava o autor, em artigo intitulado O problema do teatro (1935), “as mandingas da família deixarão de interessar como histerismo teatral”. ${ }^{1}$ A cena moderna, segundo Flávio de Carvalho, já não necessitava representar a realidade, servindo como modelo para o seu aperfeiçoamento. Nem tampouco realizava, através de diálogos dramáticos, uma história organizada com início, meio e fim. A ordenação das cenas não se precisava acontecer de maneira suave e uniforme, mas através de cortes abruptos e

\footnotetext{
${ }^{31}$ Flávio de Carvalho. “O problema do teatro”. Vanitas, nº 54, dezembro de 1935. In: Denise Mattar, obra citada, p.69.
} 
variados. O processo comunicativo da obra se dava através de um conjunto de estímulos que devia ser organizado pelos próprios espectadores a partir de pontos de vista diversos.

A arte consiste em apresentar uma série de sensações visuais e sonoras e provocar na assistência uma emoção profunda que forçosamente varia com a capacidade de perceber do assistente. O cenário não precisa ter nenhuma significação objetiva, não precisa representar os objetos que encontramos na vida. ${ }^{32}$

O processo de organização dessa leitura representava desde já um exercício de extremo valor, apontando para a renovação do modo de análise e de compreensão do mundo pelo espectador.

Os obstáculos que acompanharam a montagem de $O$ bailado do deus morto no momento de sua aparição podem ser considerados como aspectos constituintes da recepção da obra. Seria um desperdício realizar uma análise histórica do espetáculo sem levar em conta as diversas perseguições sofridas e que marcaram a sua realização. A manifestação do público, e as tantas ocorrências e proibições decorrentes do evento, contribuem para a concretização da obra. Esta primeira recepção histórica, importa ressaltar, participa de todas as outras posteriores a ela.

Nesse sentido, há uma passagem marcante, que pode ser integrada ao processo estético de concretização do espetáculo. Antes mesmo da estréia, o artista não conseguia agendar um encontro com o delegado Costa Neto, que era também o censor designado para autorizar a exibição do espetáculo.

Faziam-me esperar horas e horas propositalmente - de uma feita esperei seis horas a fio, cheguei a me mudar para o gabinete de polícia, levei livros, cadernos, régua de cálculos, alimento e lá ficava a manhã toda e toda a tarde procedendo ao expediente do meu escritório, esperando ser atendido. $^{33}$

Flávio de Carvalho, desse modo, não perdia a oportunidade, como lhe era característico, de transformar a própria estada na delegacia em um ato teatral. Como

\footnotetext{
${ }^{32}$ Flávio de Carvalho. “Teatro antigo e moderno”. Homem do povo. São Paulo, 31/03/1931.

${ }^{33}$ Flávio de Carvalho, obra citada, 1973, p.102.
} 
demonstrava em várias ocasiões, a supressão dos limites entre teatro e vida lhe interessava sobremaneira, pelo amplo potencial provocativo que sua intervenção poderia suscitar. $\mathrm{O}$ que atiçava o seu desejo investigativo e o levava a colocar-se em desafio, e mesmo em risco - como no caso da Experiência n ${ }^{\circ} 2$-, ante as possibilidades cênicas e experimentais de qualquer ato público. No fim de dez dias, encontrou o delegado saindo às pressas, evitando, como sempre, o encontro. Dessa vez não o deixou escapar e, no meio da rua, "me interpus entre o personagem oficial e o auto que o esperava, apelei por Shakespeare em plena Rua dos Gusmões, chamei a atenção sobre a liberdade de linguagem desse autor”. ${ }^{34}$ Explicou ao delegado o que seria o Teatro da Experiência, quais os seus objetivos iniciais e as propostas de experimentação que seriam realizadas junto ao público. “O povo ajuntava, e o delegado atarantado, suado e com pressa, se pronunciou verbalmente”. ${ }^{35}$ A liberação do espetáculo fora, assim, transformada em um ato artístico que participava do processo de realização do mesmo.

O espetáculo estreou no dia 15/11/1933, o público lotou a sala de espetáculos do Clube dos Artistas Modernos, que possuía 275 lugares e, segundo uma testemunha da época, "o público numeroso, representava duas vezes a lotação do teatro" ${ }^{36}$ Acerca da encenação, além dos relatos de alguns espectadores, e do próprio Flávio de Carvalho, possuímos críticas divulgadas na imprensa, fotos da apresentação ${ }^{37}$ e, por fim, o texto da peça, com apenas onze páginas.

O bailado não é um texto teatral. É um roteiro de uma experiência filosófica, visual, gestual e sonoro-vocal. Deve ser considerado como ponto de partida: roteiro de trabalho e recriação. ${ }^{38}$

O texto apresenta-se através de dois atos intitulados, respectivamente, "Bailado dos soluços” e “Confissão e o fim do deus”. No texto, não existem diálogos dramaticamente organizados, tal como nos dramas fechados, que avançam conforme o motor interno do enredo. O que encontramos aqui é um diálogo invadido pela subjetividade, em que uma fala

\footnotetext{
${ }^{34}$ Idem, p.102.

${ }^{35}$ Idem, p.102.

${ }^{36}$ Sangirardi Jr, obra citada, p.45.

${ }^{37}$ Ver foto na página seguinte.

${ }^{38}$ Lívio Tragtemberg, Artigos musicais. São Paulo, Perspectiva, 1991, p.79.
} 


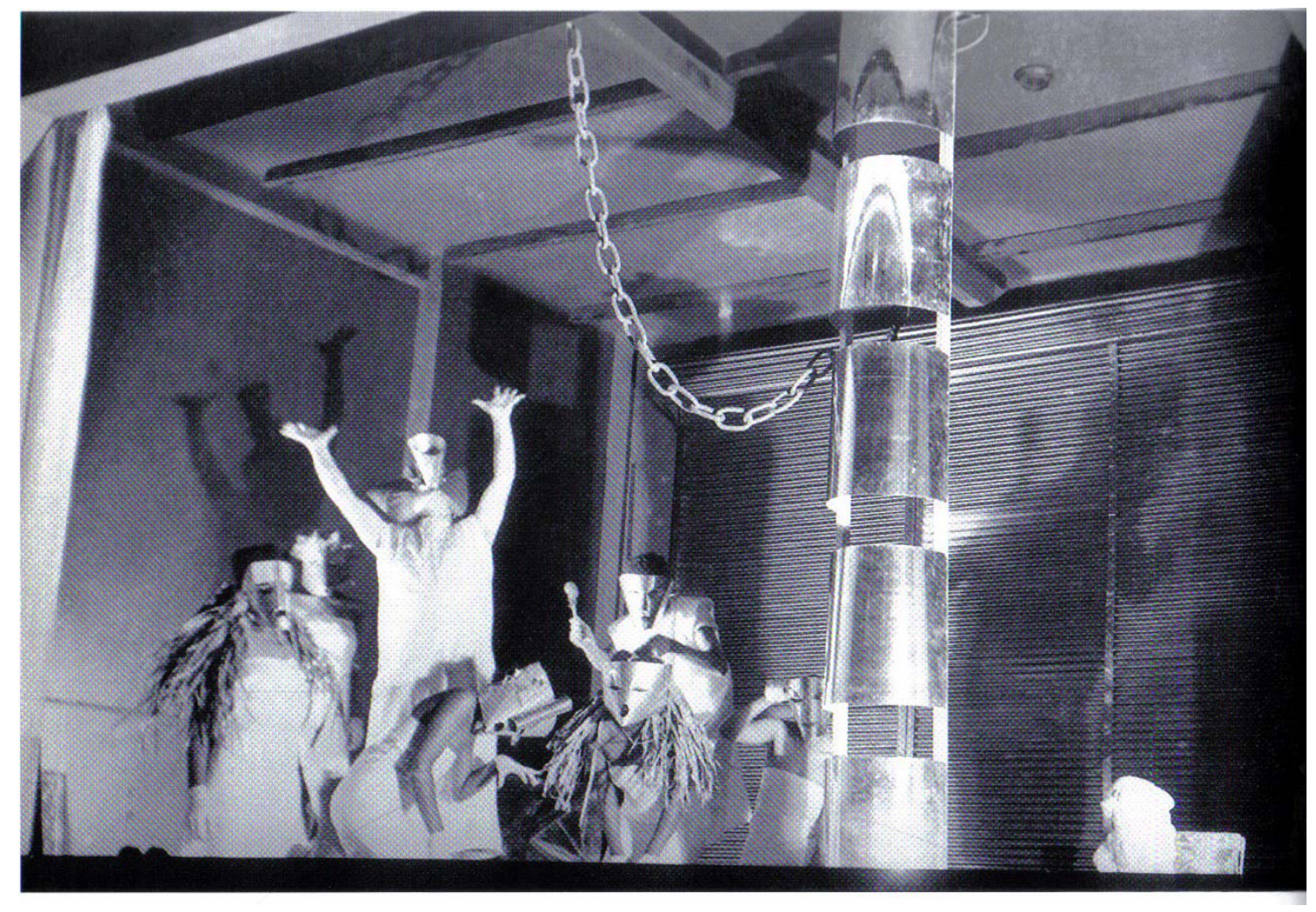

Flávio de Carvalho

1933

Bailado do deus morto

Clube dos Artistas Modernos de São Paulo 
se choca contra a outra. As cenas são marcadas por soluços e lamentos, as vozes perturbadoras originárias do inconsciente dos personagens, que surgem nos dramas modernos transbordando entre as falas, representam aqui todo o texto.

O elenco, que em cena possuía o rosto coberto por máscaras de alumínio e utilizava longas túnicas brancas, era formado por um grupo de músicos e dançarinos. O único participante que possuía experiência anterior como ator era o também pintor e desenhista Hugo Adami, que havia trabalhado na companhia de Leopoldo Fróes.

O público variado e bem maior que a capacidade da casa viu, atônito, a bombástica e estrepitosa interpretação de Hugo Adami que, numa retumbante performance improvisatória, pronunciou o seu sonoro "puta do pecado" que entrava para a história, como sendo o primeiro palavrão do nosso teatro. ${ }^{39}$

O cenário era composto por um totem de alumínio colocado no centro do palco e correntes que desciam do teto do teatro. O alumínio acompanhou Flávio em diversas invenções, e aqui o material ajudava a expandir os efeitos de luz propostos pelo encenador. As túnicas brancas também eram realçadas pela iluminação, assim como a transparência da gaze, material utilizado pelo encenador para o pano de boca. Através de depoimento deixado por Procópio Ferreira, espectador presente na ocasião do espetáculo, notamos o efeito que tais invenções podiam causar no público:

O palco era pequeno. A decoração era interessantíssima feita com tubos de alumínio pregados na parede, um processo absolutamente novo. Tarsila do Amaral, Ester Bessel, Oswaldo Júnior, Lívio Abramo, Oswaldo Sampaio e Flávio de Carvalho. A iluminação era indireta, distribuída por um processo científico. A primeira coisa que se notava no palco era o pano de boca transparente. O Sr. Flávio de Carvalho explicava que isto era necessário como processo de distribuição de luzes e sombras. Produzia dois efeitos numa só cortina: opacidade e transparência, luz à frente ou atrás. ${ }^{40}$

\footnotetext{
${ }^{39}$ Toledo J., obra citada, p.182.

${ }^{40}$ Procópio Ferreira, Procópio Ferreira apresenta Procópio: um depoimento para a história do teatro no Brasil. Rio de Janeiro, Rocco, 2000, p.200.
} 
A primeira cena do espetáculo apresenta o coro de atores cuidadosamente colocado no palco, desenhando, através de duas linhas que se encontram no fundo da cena, a letra V. Na ponta da letra, encontra-se o Lamentador, personagem que aos poucos abandonará o coro. Os instrumentos musicais são executados também pelo coro, uma música de tantã ressoa durante alguns minutos. Ouve-se então uma voz que anuncia o motivo condutor de todo o espetáculo: “O deus é morto”. ${ }^{41}$

O coro reage à enunciação com choro e soluços e "canta em uníssono o canto do deus morto" acompanhado de um tantã. ${ }^{42}$ A cena lembra um ditirambo dionisíaco. O Lamentador, personagem executado por Adami, e que parece funcionar como uma espécie de Corifeu, no momento em que é anunciada a morte do deus, levanta-se, aproxima-se da platéia e com o tórax inclinado, as mãos e os braços alongados, o que acentuava o desenho de sua figura mascarada, pronuncia com voz grossa e cadenciada: “O deus morreu”. ${ }^{43} \mathrm{O}$ coro repete baixinho e de forma desencontrada a mesma sentença e principia a chorar. Aos poucos, a movimentação do coro se intensifica, enquanto o Lamentador continua se movimentando e formando figuras geométricas. Quando retoma a fala, o Lamentador estanca a postura desenhada no espaço.

L: Oh deus peludo...(gongo) o teu cabelo ondulado era comprido como o da mulher... (gongo) .... teu corpo vestido de folhas....

L começa a se mexer, o tantã diminui.

V2: Os bichos e as folhas gostavam de você... (gongo) ... os bichos e as folhas gostavam de você... (braços retos para cima) (gongo)... você era o igual das feras do mato...(gongo).

Logo depois do gongo dá-se a mudança do ritmo, o lamentador que estava imóvel começa agora a se mexer, o tantã diminui de intensidade, o Lamentador dança para a direita e para a esquerda do palco com movimentos geométricos, mesmo depois do tantã ter cessado.

L (parado em frente ao palco): (os dois braços para cima em L): Antes do pecado oh deus...você pastava entre as feras do mato...(gongo).

O capim era verde e gostoso ... (gongo).

L: (com movimentos quebrados e sem sair do lugar) (uma figura geométrica para cada frase): Oh deus dos homens ... (gongo) ... a puta do pecado te arrancou das folhagens e das feras...

\footnotetext{
${ }^{41}$ Flávio de Carvalho, obra citada, 1973, p.81.

${ }^{42}$ Idem, p.82.

${ }^{43}$ Idem, p.82.
} 
(gongo) ... você matou e traiu as feras do mato ... (gongo) o teu corpo deus prostituto cheira ao ungüento da civilização... (gongo) você bebe cerveja e usa roupas que a puta te ensinou ... (gongo). ${ }^{44}$

Ao fim deste trecho o coro chora compulsivamente, com soluços repetidos e sem orquestra, durante dois (longos) minutos. Em seguida, realizam o que o autor denominou a dança do comichão: girando em roda, três ou quatro vezes, e coçando todo o corpo ao ritmo da música. Os lamentos seguintes revelam o desespero dos homens perplexos. Diante da constatação de que morreu aquele que tudo sabia, o coro se pergunta: "aonde irão os homens perplexos?”. ${ }^{45} \mathrm{O}$ ato termina com o fechamento do pano de boca. O coro recua e os instrumentos silenciam.

Durante a mudança do primeiro para o segundo ato, graças à visibilidade fornecida pela gaze, os espectadores podiam adentrar à cena, romper a ilusão de continuidade e enxergar o que acontecia atrás do pano de boca.

No segundo e último ato, contando novamente com a transparência do tecido, a cena começa antes de abrir a cortina.

Antes de subir o pano.

Orquestra e coro em 2 filas, música de tantã espaçado e baixinho.

Cântico nostálgico prolongado.

L: Oh deus ... sombrio e taciturno...para onde vamos?

V1: Para o mundo onde as minhocas devoram e onde tudo é poeira...

Cântico nostálgico.

V1: É o canto do sofredor...

L: Escuta o cântico .... escuta .... shsh .... shsh .... (soprando baixinho) é o latido do homem superior...oh deus calado ...(com força) responde ... o teu silêncio castiga os homens perplexos... (baixo e com força) para onde vamos?...

Cântico nostálgico e prolongado.

O pano sobe enquanto o cântico continua. ${ }^{46}$

\footnotetext{
${ }^{44}$ Idem, p.83.

${ }^{45}$ Idem, p.85.

${ }^{46}$ Idem, p.87.
} 
A cena continua agora sem o efeito provocado pela cortina fechada. O deus que morreu entre os animais, vítima de uma cilada, é transportado para "o mundo onde as minhocas devoram e onde tudo é poeira”. ${ }^{47}$ O deus, taciturno e calado, seduzido pela mulher, agora já não pode mais reinar entre as feras do mato. A mulher, agora com a barriga cheia "como a esfera celeste” ${ }^{48}$, colocará novos seres no mundo. E o Lamentador avisa:

L: (voz grave e cadenciada) É a mecanização do mundo. ${ }^{49}$

A partir de então, os personagens do coro “eletrizados” e colocados em linha na frente do palco, ao som de um batuque baixinho, perguntam o que fazer com o corpo de deus. O Lamentador responde o que acontecerá com cada uma das partes, ora com voz alta, ora grave e triste e ora pronunciando bem as sílabas. Ao fim, como um Doutor Frankenstein, o Lamentador declara que fabricará com as glândulas e gânglios do deus morto, um novo deus. O pano cai e depois disso ouve-se, de uma voz sombria e triste, a sentença final: “a psicanálise matou o deus”. 50

\section{Diálogos e referências.}

O homem é uma corda, atada entre o animal e o além-dohomem - uma corda sobre um abismo.

Nietzsche

Entre as diversas referências utilizadas por Flávio de Carvalho para a construção de O bailado,- através da movimentação cênica, por exemplo, fica clara a alusão aos rituais religiosos africanos - aparece a epopéia de Gilgamesh, apontada pelo próprio autor em entrevista concedida em 1945 como obra que havia lhe deixado vivamente impressionado. ${ }^{51}$

\footnotetext{
${ }^{47}$ Idem, p.87.

${ }^{48}$ Idem, p.90.

${ }^{49}$ Idem, p.90.

${ }^{50}$ Idem, p.92.

${ }^{51}$ Flávio de Carvalho, apud Rui Moreira Leite, obra citada, p.146.
} 
A epopéia ${ }^{52}$ citada por Flávio como referência para a construção de sua peça, tem origem na Mesopotâmia, cerca de 4 mil anos antes de Cristo e apresenta, entre outras narrativas, o encontro entre o rei de Uruk, Gilgamesh, metade deus e metade homem e Enkidu, metade homem e metade animal. Tal como o deus apresentado na primeira cena do Bailado, Enkidu é descrito aqui como o filho das águas e dono do mundo selvagem.

Seu corpo era rústico, seus cabelos como os de uma mulher; eles ondulavam como o cabelo de Nisaba, a deusa dos grãos. Ele tinha o corpo forte e coberto por pelos emaranhados. ${ }^{53}$

Quando chegou à terra, Enkidu, forte como um touro selvagem, vivia entre os bichos das florestas, comia mato e bebia água das nascentes, como eles. Ao ser descoberto, reinando entre os animais, Enkidu, recebe a visita de uma das sacerdotisas de Ishtar, a deusa do amor, que passa sete noites ao seu lado. Após esse período, o homem criado por deuses, meio homem meio animal, não consegue mais se aproximar dos bichos que fogem de seu antigo aliado, pois não mais o reconhecem.

Para sermos exatos, devemos dizer que ele não estava separado de sua natureza animal, mas da sua participação mística, da sua identificação com a natureza animal. ${ }^{54}$

Ao se aproximar da sacerdotisa, Enkidu, que reinava até então como um deus na natureza, perde a capacidade de se relacionar com os animais da selva. O conhecimento adquirido acerca dos homens e da vida longe do mundo animal, através da convivência durante seis dias e sete noites com a mulher, o transforma, mas também o enfraquece. "Enkidu perdera sua força, pois agora tinha o conhecimento dentro de si e os pensamentos do homem ocupavam seu coração" ${ }^{55}$ A sacerdotisa o acompanha, então, até o reino de

\footnotetext{
${ }^{52}$ A partir da A epopéia de Gilgamesh, o diretor teatral Antunes Filho criou o espetáculo Gilgamesh em 1995. Trabalho que resultou em livro: Antunes Filho, Gilgamesh: adaptação teatral de Antunes Filho. São Paulo, Editora Veredas, 1999.

${ }^{53}$ A epopéia de Gilgamesh. Anônimo. Tradução Carlos Daudt de Oliveira, São Paulo, Martins Fontes, 2001, p.94.

${ }_{54}$ Rivkah Scarf Kluger, O significado arquetípico de Gilgamesh: um moderno herói antigo. São Paulo, Paulus, 1999, p.50.

${ }^{55}$ A epopéia de Gilgamesh, obra citada, p.97.
} 
Gilgamesh, de quem se tornará companheiro fiel até o fim da vida. Enkidu é compreendido em alguns estudos acerca da obra como uma espécie de duplo de Gilgamesh. ${ }^{56}$

No Bailado a condição descrita acima é apresentada no primeiro ato: "você matou e traiu as feras do mato ... (gongo) ... o teu corpo deus prostituto cheira ao ungüento da civilização... (gongo)”. ${ }^{57}$ O bailado do deus morto não se propõe a contar a longa e complexa narrativa de Gilgamesh, porém se constitui em diálogo com a mesma e, em especial, com o aparecimento de Enkidu. Como uma espécie de interlocutor, Flávio traz o mito da antiguidade para pensar questões atuais. A questão principal do Bailado, assim como a trajetória de Enkidu, se refere ao processo de evolução do homem selvagem primitivo para o homem civilizado. Do homem alinhado com a natureza ao homem individualizado, do homem ancestral ao homem moderno.

Flávio de Carvalho, ao clamar pelo retorno ao universo mítico, apoiado também na obra de Nietzsche, como referido anteriormente, quer acessar as regiões profundas da psique, fazendo surgir uma potência interpretante que revolucione a tristeza, a amargura, a dor, estabelecidas como padrão de sobrevivência. Assim, em O bailado o encenador denuncia a recusa dos homens perplexos em admitir a alegria da vida, do corpo, da animalidade, desnudando a máscara da hipocrisia e a lágrima triste da resignação.

Este ódio de tudo que é humano, de tudo que é animal, e mais ainda de tudo que é matéria, este temor dos sentidos... este horror da felicidade e da beleza; este desejo de fugir de tudo que é aparência, mudança, dever, morte, esforço, desejo mesmo, tudo isso significa... vontade de aniquilamento, hostilidade à vida, recusa em se admitir as condições fundamentais da própria vida. $^{58}$

Através de $O$ bailado do deus morto, Flávio de Carvalho colocava em cena questão discutida anteriormente com a Experiência $n^{\circ} 2$ : romper a normalidade das experiências coletivas para trazer à tona a alma da multidão. Nas duas experiências se faz presente a integração entre criação artística e investigação científica.

\footnotetext{
${ }^{56}$ Rivkah Scarf Kluger, obra citada, p. 35.

${ }^{57}$ Flávio de Carvalho, obra citada, 1973, p.83.

${ }^{58}$ Friedrich Nietzsche, Obras Incompletas. Editora Nova Cultural, São Paulo, 1999, p. 11.
} 
A visão psicanalítica-antropológica de crítica da religião permanecerá no centro das preocupações posteriores de Flávio. (...) Trata-se da fundação do Teatro da Experiência e da encenação da peça de sua autoria $O$ bailado do deus morto. Uma interpretação metalingüística das idéias expostas na Experiência ${ }^{\circ} 2^{59}$

A recusa de Carvalho em face da espetacularidade dominante, presente nas mais variadas manifestações culturais de seu tempo, do teatro aos eventos religiosos, manifesta sua atenção a aspectos fundamentais acerca de como as sociedades concebem seu modo de viver. Pois, “os modos de vida inspiram maneiras de pensar, os modos de pensar criam maneira de viver". ${ }^{60}$ Dessa maneira, os modos de organizar os atos teatrais indicam maneiras de compreender a função da arte em sua relação com a vida, e podem fomentar questionamentos ao estabelecido e a invenção de novos modos de viver.

$\mathrm{O}$ ato artístico é compreendido, assim, como um reagente que atua alterando a química dos princípios. Uma tentativa extremada de tocar a raiz da questão: o próprio modo padronizado, estabelecido, inalterável.

Os homens, atônitos ante o corpo do deus morto, carregam piedosamente seu cadáver, convencidos da culpa pela autoria do assassinato, e fazem das lágrimas a penitência necessária, enquanto esperam secularmente por seu renascimento e sua volta triunfal. O que os impede de inventar e viver a divindade que lhes é própria, plena de riso, de música e de dança. Com isto, Flávio de Carvalho indica que não basta matar o deus para operar a necessária transmutação de valores, e, com forte inspiração nietzschiana, nos lança uma provocação, a qual pode ser compreendida nos seguintes termos:

[...] o homem se avilta ainda quando, já não tendo necessidade de uma instância exterior, se proíbe a si próprio o que lhe proibiam, e se encarrega espontaneamente de uma vigilância e de fardos que já não lhe parecem vir do exterior. ${ }^{61}$

No Bailado, o artista constrói um ritual e aos poucos vai destruindo-o. O primeiro ato narra, através de cantos e danças ritualísticas, a constatação de que o deus está morto e, por conseguinte, a perplexidade dos homens que se perguntam o que farão sem aquele que

\footnotetext{
${ }^{59}$ Antonio Carlos Robert de Morais, Flávio de Carvalho. São Paulo, Brasiliense, 1984, p.35

${ }^{60}$ Gilles Deleuze, obra citada, p. 18.

${ }^{61}$ Gilles Deleuze, obra citada, p. 22.
} 
tudo presenciou, o único em condições de lhes ditar o rumo a seguir. No segundo ato, através de um corte abrupto, não temos mais alusões aos cantos ditirâmbicos, o ritual some do palco. A mecanização do mundo, indicada pelo Lamentador e simbolizada pelo coro eletrizado e enfileirado na frente do palco, nos remete aos tempos industrializados, onde tudo pode ser reaproveitado. Assim o pêlo de deus servirá para a fabricação do pincel, os ossos para farinha de osso, os chifres para a feitura de pentes, facas e botões. O ritual é, então, desmanchado. O universo mítico decai e perde lugar para a perspectiva lógicoracional de compreensão do mundo e da religiosidade.

Na Experiência $n^{\circ}$ 2, Flávio encontra um ritual já pronto e põe-se a desmontá-lo. A caminhada em direção contrária à procissão religiosa representava a experimentação prática de certas hipóteses levantadas pelo artista sobre as transformações emotivas das massas, quando desafiadas em seu fervor religioso. O desafio aparecia justamente na quebra do ritual provocada pelo artista. O sentido contrário e o chapéu que mantinha na cabeça funcionavam como uma espécie de peça estranha na engrenagem coletiva.

Era dia de Corpus Christi; um sol agradável banhava a cidade, havia um ar festivo por toda parte; mulheres, homens e crianças moviam cores berrantes de tecido ordinário; negras velhas de óculos e batina ou qualquer coisa de parecido; grupos de homens segurando estandartes, velas; anjinhos sujos enfeitados com estrelas de papel dourado mal pregadas, mulheres gordas vestidas de cor de rosa cabelo bem emplastado olhavam o mundo em redor com infinita piedade (...).

Contemplei por algum tempo este movimento estranho de fé colorida, quando me ocorreu a idéia de fazer uma experiência, desvendar a alma dos crentes por meio de um reagente qualquer que permitisse estudar a reação nas fisionomias, nos gestos, no passo, no olhar, sentir enfim o pulso do ambiente, palpar psiquicamente a emoção tempestuosa da alma coletiva, registrar o escoamento dessa emoção, provocar a revolta para ver alguma coisa do inconsciente. Dei meia volta, subi rapidamente em direção à catedral, tomei um elétrico e meia hora depois voltava munido de um boné. $^{62}$

O "reagente" apontado - como num experimento científico, que ao ser aplicado espera-se um efeito, mas não se sabe qual - era o próprio autor que se punha na contramão do fluxo. Com 1,90m de altura, Flávio de Carvalho despontava no meio da multidão como

\footnotetext{
${ }^{62}$ Flávio de Carvalho, Experiência nº: realizada sobre uma procissão de Corpus Christi: uma possível teoria e uma experiência. Rio de Janeiro, NAU, 2001, p.15-16.
} 
um elemento estranho, tanto para os que seguiam a procissão, quanto para os que observavam o cortejo. Como uma engrenagem que está se movimentando corretamente e revela repentinamente um elemento dissonante, que aparece fora do lugar, como uma roldana que estivesse solta, a presença do artista anunciava uma transformação, solicitava uma mudança de atitude.

Aqueles que eram da procissão se portavam diferentemente, eles eram os eleitos de deus, os escolhidos e formavam uma massa em movimento lento, contrastando em qualidade com a assistência imóvel; eram, portanto, praticamente, o único movimento em todo o imenso percurso da procissão e esta situação de movimento naturalmente exigia o monopólio da atenção geral, e uma presença perturbadora como era a minha deveria influir diferentemente na procissão em movimento e na assistência. ${ }^{63}$

Como se em uma engrenagem dramática um elemento girasse na direção oposta e desfizesse o efeito esperado, quebrando a rotina do esperado e exasperando os participantes-espectadores. A teatralidade do evento religioso, e as perspectivas ideológicas que a constituem, se viam ameaçadas ante a interferência performática. Os olhares mais assustados e ofendidos vinham dos que estavam assistindo à procissão e não dos que participavam dela. Os seguidores do ritual olhavam estranhamente a figura desajustada que atravessava a procissão e improvisavam reações ao tom de sua presença.

Os padres rezavam com mais fervor, as freiras incrédulas não compreendiam, os velhos se pareciam com as velhas, eram de uma resignação efeminada, lendo o breviário de mais perto, apertando mais o terço ou olhando para o céu com mais afinco. ${ }^{64}$

Já os espectadores, que observavam o espetáculo-ritual, sentindo-se profundamente incomodados, passaram a perseguir o artista pelas ruas, com palavras de ordem como “pega”, “lincha” e “mata”. Em condição ambígua, o ritual religioso virava espaço de pesquisa e a provocação estética servia como uma espécie de reagente aos processos coletivos de idolatria religiosa. Ao caminhar no sentido inverso da procissão de crentes, o artista pode ser comparado com o Lamentador, personagem d'O Bailado, que apontava a

\footnotetext{
${ }^{63}$ Idem, p.16.

${ }^{64}$ Idem, p.17.
} 
morte do deus diante do coro e clamava por uma atitude reativa, inventiva dos homens perplexos.

Nas duas experiências, na procissão e no teatro, Flávio lançava mão de uma proposta investigativa sem fim premeditado, sujeita a surpresas e ações imprevisíveis. As propostas se davam sem que a participação do espectador ficasse de antemão resolvida. $\mathrm{O}$ efeito diante da procissão era inesperado, assim como a leitura do espetáculo. Os espectadores se viam convidados, a partir de elementos dissonantes, a efetivar uma leitura própria, não racional, não preconcebida pelo artista. Um convite sugestivo, como o próprio encenador compreendia a função da arte, que produzia efeitos inesperados e demandava atitude criativa aos participantes.

Mais tarde, no ano de 1956, Flávio de Carvalho idealizou outra experiência pública: a partir dos seus escritos acerca de “A moda e o novo homem”, publicados no Diário de São Paulo, ${ }^{65}$ criou "o traje de verão masculino”, o qual seria composto por blusão, saiote, sandálias e perna nua ou com malha de tecido aberto. O traje foi confeccionado por Maria Ferrara, que dirigia o ateliê de costura do Ballet do IV Centenário. No dia 18 de outubro daquele ano, o artista caminhou pelas ruas do centro de São Paulo envergando a nova vestimenta. ${ }^{66}$ A repercussão nas ruas da cidade foi tão intensa que o autor chegou a pensar no estudo Experiência $n^{\circ} 3$, dedicado à análise das reações provocadas. ${ }^{67}$

\section{Embate estético.}

As investigações cênicas de Flávio de Carvalho mostram-se como experiências abertas que explodem o sentido único de uma dramaturgia bem feita, a qual pretende, através do desenlace, do final bem acabado, chegar a um lugar imaginado de antemão pelo autor. Como seus projetos arquitetônicos, cada experiência artística esboçada contém o desejo de um manifesto, o qual nesse caso pode ser definido como o desejo de discutir as noções modernas de teatro e da relação entre arte e sociedade. No caso do Bailado, o que estava em questão não era somente a existência ou não de deus, mas o conceito de teatro defendido e praticado entre nós.

\footnotetext{
${ }^{65}$ Os artigos foram publicados no Diário de São Paulo de 4/03/1956 a 21/10/1956.

${ }^{66}$ Ver foto na página seguinte.

${ }^{67}$ Laís Moura, apud Rui Moreira Leite, obra citada, p.123.
} 


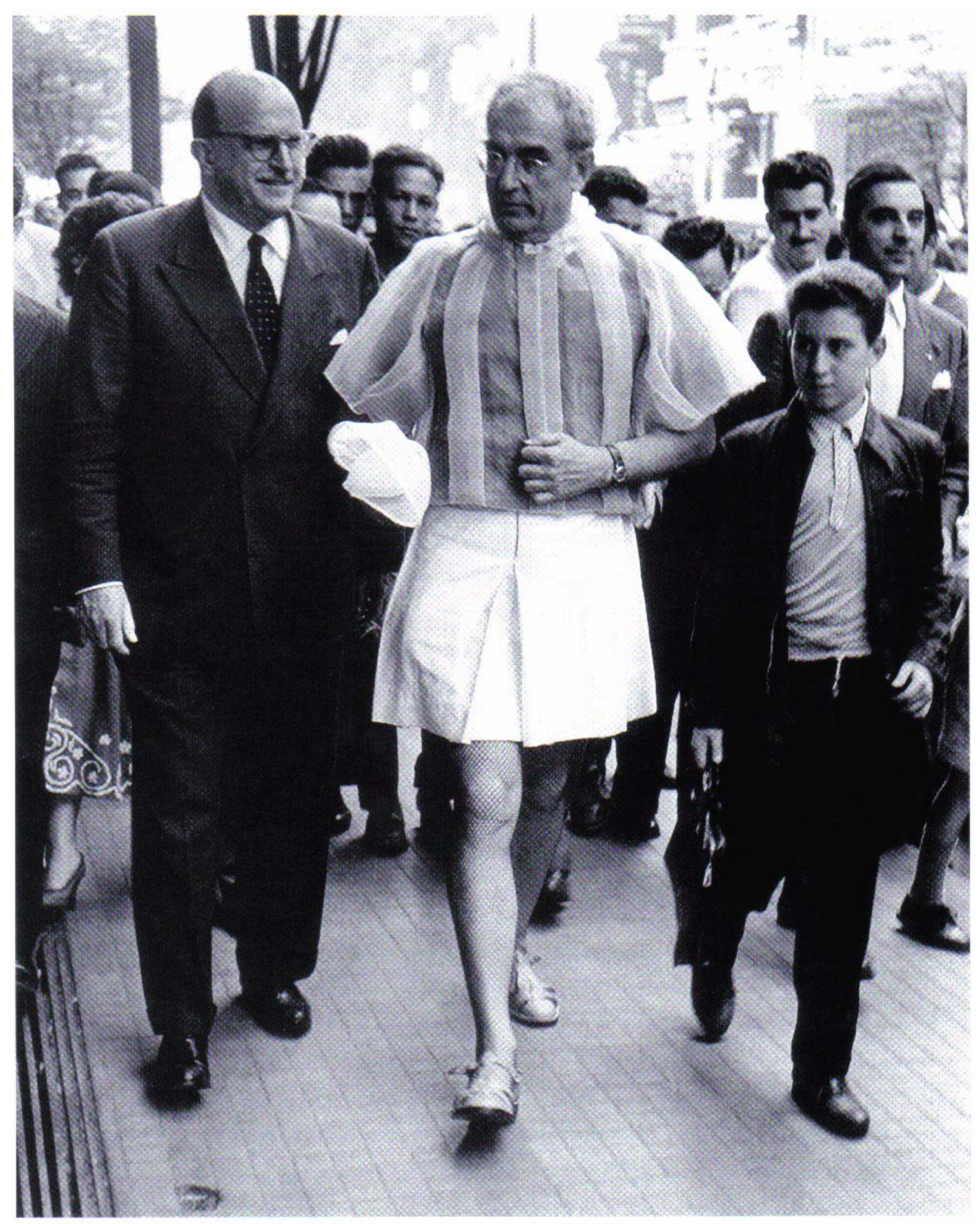

Flávio de Carvalho

1956

A moda e o novo homem 
Se colocado ao lado da lógica do drama burguês, presente nas nossas comédias, o Teatro da Experiência demonstra o desejo de afastamento da lógica do drama fechado. As cenas construídas não são desprovidas de representação, porém não são dominadas por sua lógica. Importa menos o conteúdo da peça e mais o modo como ela se configura: repleta de ruídos, com cenas que se chocam umas contra as outras, com signos diversos produzindo efeitos variados.

O embate estético, que é também político, desferido por Flávio pode ser visto no conjunto de sua obra. As percepções, anotadas em livros, em entrevistas e em artigos publicados na imprensa paulistana e carioca nas décadas de 1930 e 1940, são de extrema importância, pois revelam o questionamento moderno da arte presente no pensamento e nas proposições do autor. Seus textos soam com uma pertinência surpreendente se comparados às correntes modernas do pensamento artístico e, ao mesmo tempo, totalmente estranhos se confrontados com a realidade teatral brasileira que os cercavam.

Ao mesmo tempo em que declarava que "as forças democratizantes do mundo" apontavam para a necessidade de que as casas abandonassem "seus trajes agressivos de fortaleza” e estabelecessem um contato mais intenso com o mundo ao seu redor, assumindo as novas noções de coletividade determinantes para a arquitetura moderna - "a famosa fórmula britânica home sweet home cai em desuso: a morbidez que movia esse culto ao lar desaparece; mal restam hoje as cinzas dos deuses defuntos dos lares”68 -, Flávio enxergava a necessidade do teatro de estabelecer um diálogo mais amplo e efetivo com a sociedade. Para tal fim tornava-se urgente que a cena se voltasse para temas que fugissem da esfera privada, da família e de seus respectivos dilemas.

Seguindo o mesmo raciocínio, percebia a importância de quebra de horizontes expectativos para a realização de uma arte realmente frutífera. Defendia a frustração dos espectadores habituados a um teatro para agradar e, em troca, construía um convite efetivo de participação destes nos meios de produção da obra de arte.

A arte "chapa”, a arte que agrada ao espírito médio e que vende com facilidade, é sempre ruim. Um dos melhores testes para determinar se um artista é ruim ou bom é observar se ele está ou

\footnotetext{
${ }^{68}$ Flávio de Carvalho, apud Rui Moreira Leite, obra citada, p.86.
} 
não vendendo seus quadros. Pondo de lado questões de moda e outros fatores de influência secundária, aquele que mais vende e que mais cai no agrado do público é quase sempre o pior e o mais medíocre de todos. (Isto naturalmente não quer dizer que todos os artistas que não vendem os seus quadros sejam bons artistas e nem que todos os que vendem sejam medíocres). ${ }^{69}$

Desse modo, Flávio de Carvalho ecoava trágicas inquietações estéticas do seu tempo e caminhava em oposição ao que era consensualmente considerado primordial para a construção de um teatro nacional. Entre tantas ambições, lutava para desarmar a percepção embotada, as velhas crenças, os dogmas infligidos ao fazer artístico.

À medida que a pintura se torna mais pintura, o valor "assunto" diminui. (...) o assunto, que é uma concretização visual de uma história, não se acha presente, ou quase, na obra do artista contemporâneo. $^{70}$

A percepção da falta de importância do “assunto” na obra, como compreendia Flávio, corresponde a um desdobramento que atinge a arte desde o fim do século XIX, e permanece como premissa radicalizada até os dias de hoje. No caso da pintura, no lugar da ilusão do espaço tridimensional e da organização de um assunto, surge a realidade das cores, a materialidade do processo de criação. O assunto principal da arte moderna torna-se o próprio fazer artístico, a análise, a auto-reflexão.

O projeto moderno, convém lembrar, representou um esforço duplo e contraditório: matar a arte para salvá-la. Questão de sobrevivência - ou pensar a inteligência negativa de si mesma ou correr o risco de morrer despercebida do tumulto de um mundo anônimo e feroz. ${ }^{71}$

\section{$[\ldots]$}

A técnica deixa de ser meio expressivo do sujeito. Ao contrário, passa a ser necessidade objetiva de os artistas dominarem uma racionalidade profunda e generalizada para acompanhar as determinações do sistema cultural. Necessidade de investigar o seu campo de atuação ao nível da consciência crítica. ${ }^{72}$

\footnotetext{
${ }^{69}$ Flávio de Carvalho. “A única arte que presta é a arte anormal.” Diário de São Paulo, 24/09/1936. In: Denise Mattar, obra citada, p.71.

${ }^{70}$ Flávio de Carvalho, “A luta nos domínios da arte”, O Cruzeiro, 02/04/1938. In: Denise Mattar, obra citada, p.76.

${ }^{71}$ Ronaldo Brito, obra citada, p.75.

${ }^{72}$ Idem, p.80.
} 
A pintura moderna devia, portanto, ser compreendida como uma estruturação própria e nova. O que, obviamente, não significa que ao se voltar para a autonomia da linguagem a arte se desvincule do interesse pelo indivíduo ou pelo processo histórico que o rodeia. Se trata, antes, de uma nova visão: no lugar do desenho bem-feito, surge uma arte que quer revelar o processo de construção da pintura, e colocar em questão a função do artista e o papel do espectador.

Nos retratos produzidos pelo artista, através de pinceladas vibrantes e cores fortes, o artista assinalava a tentativa de mostrar o que estava por trás da fisionomia, trazer à tona regiões profundas da psique. Por isso, Mário de Andrade, ao ver o seu retrato feito por Flávio, reagiu com espanto: ${ }^{73}$

Quando olho para o meu retrato pintado pelo Segall, me sinto bem. É o eu convencional, o decente, o que se apresenta em público. Quando defronto o retrato feito pelo Flávio sinto-me assustado, pois vejo nele o lado tenebroso de minha pessoa, o lado que eu escondo dos outros. ${ }^{74}$

O artista declarava que, ao desenhar, no lugar da representação fiel, perseguia as emoções da figura humana. As pincelas largas e encorpadas, as cores intensas buscavam a apreensão de gestos reveladores dos retratados e acabavam por sugerir em seus espectadores efeitos também diversos.

No caso do teatro, desaparece a idéia de representação do mundo, através de ações desencadeadas no presente contínuo. A vida ativa no presente cede espaço à vida onírica na lembrança e na utopia. ${ }^{75} \mathrm{O}$ interesse em tratar de problemas que fogem da esfera privada se intensifica como também se aprofunda a mistura de linguagens. O teatro moderno não somente supera a estrutura da lógica da peça bem feita, como em seu decorrer radicaliza suas proposições advindas a partir da crise do drama.

No texto de O Bailado do deus morto desaparecem os princípios e o ordenamento da fábula, as cenas são apresentadas sem obedecer à lógica do encadeamento causal, cada cena rompe com a anterior e a narrativa avança através de golpes sonoros e perceptivos.

\footnotetext{
${ }^{73}$ Ver foto na página seguinte.

${ }^{74}$ Mário de Andrade, apud Rui Moreira Leite, obra citada, p.79.

${ }^{75}$ Peter Szondi, Teoria do drama moderno (1880-1950). São Paulo, Cosac e Naify Edições, 2001, p.91.
} 


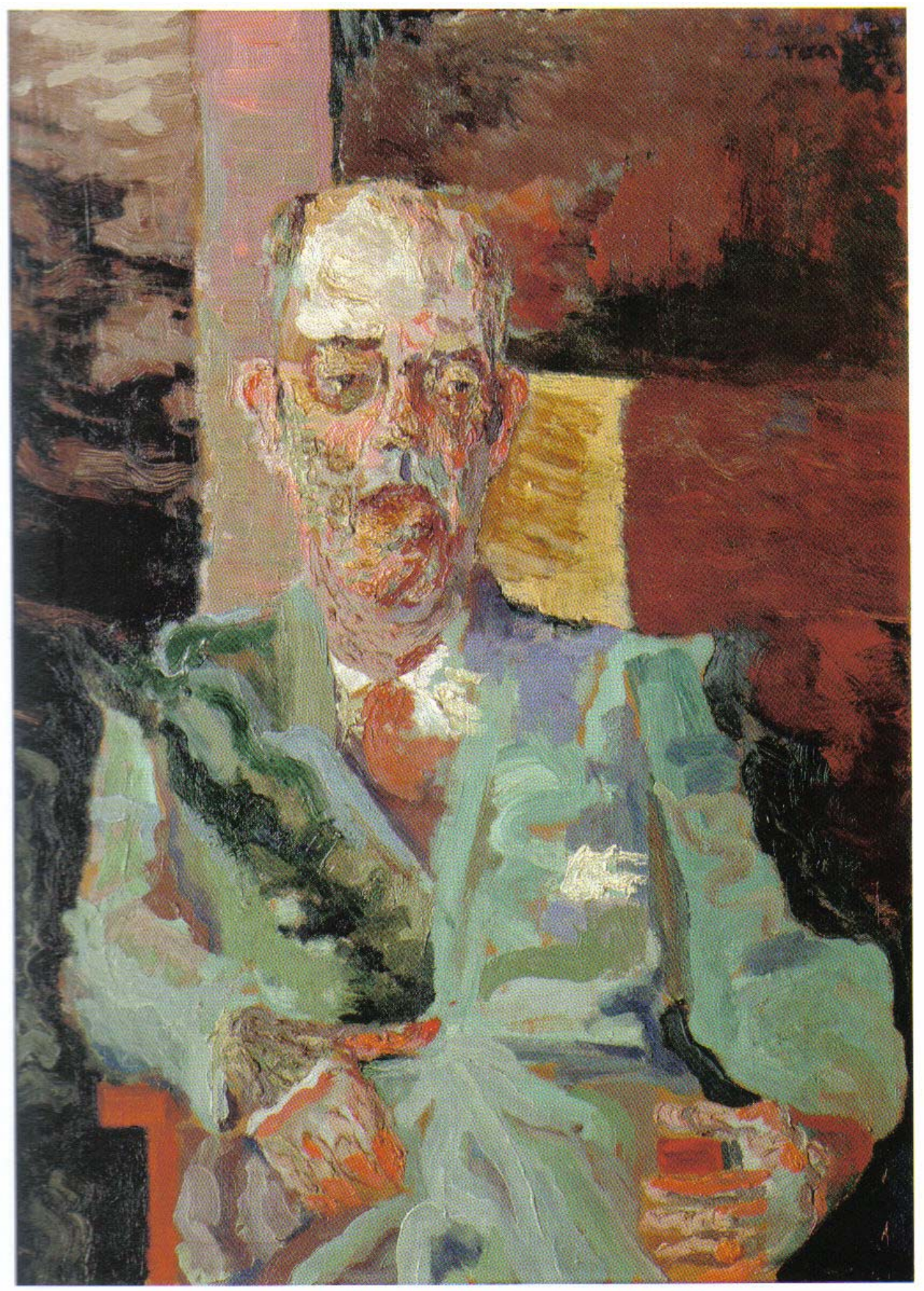

Flávio de Carvalho

1939

Retrato de Mário de Andrade

111 × $80 \mathrm{~cm}$

Pinacoteca Municipal / Centro Cultural São Paulo 
Esta configuração cênica apresentada pelo Teatro da Experiência surgia de forma contrária às expectativas com as quais o público costumava encarar os textos dramáticos, e resultava numa experimentação nova para a qual ainda não havia regras gerais de análise.

É difícil acreditar que Flávio de Carvalho e suas elucubrações estéticas ocorressem ao mesmo tempo em que o teatro brasileiro via-se representado, principalmente, pelas comédias de costumes de sucesso nos palcos das cidades de São Paulo e Rio de Janeiro. Flávio representava um pensamento marginal, considerado um excêntrico pelos seus contemporâneos. Nesta contramão em que se encontrava, descobrimos estímulos para compreender a história do teatro brasileiro, revista através não da constatação do que aconteceu, do que subiu aos palcos com sucesso de público e respaldo da crítica, mas do resgate de dados de um teatro propositor de embate estético submetido a sucessivos vetos. 


\title{
Capítulo 5
}

\section{Oswald de Andrade: a invenção do espectador.}

\begin{abstract}
Toda a minha produção há de ser de protesto e embelezamento, enquanto eu não puder derramar sobre as brutalidades coletivas a potência dos meus sonhos.
\end{abstract}

Oswald de Andrade ${ }^{1}$

Na década de 1930, quando Oswald de Andrade escreve o seu segundo conjunto de peças, o procedimento analítico e auto-reflexivo da arte, próprio da modernidade, se vê aguçado e, mais do que isso, organizado em projeto dramatúrgico. Através das peças $O$ rei da vela, A morta, $O$ homem e o cavalo e $O$ santeiro do mangue, Oswald realiza uma espécie de devoração do velho material lingüístico, do qual ele mesmo se valeu nas suas primeiras tentativas como dramaturgo, e escreve textos completamente diversos dos primeiros, propondo um teatro em plena tensão com as obras vigentes e que se abria para uma produtiva interlocução com variados gêneros e estilos.

Se nas primeiras peças, Leur âme e Mon coeur balance, escritas em francês, em parceria com o poeta Guilherme de Almeida, e publicadas em 1916, “os diálogos se desenvolvem com certa espontaneidade e as cenas se encaixam naturalmente umas nas outras"2, motivadas por problemas de amor, casamento e adultério, buscando uma espécie de boa carpintaria teatral, nas peças posteriores, ao contrário, a marca da invenção se faz característica marcante de sua produção.

A primeira impressão, de ordem geral, é a de um violentíssimo esforço do escritor no sentido de alcançar um tipo de criação teatral quase automática, onde a noção de carpintaria seja logo vencida e dominada pela mais absoluta liberdade de invenção. Oswald coloca-se, imediatamente, por uma espécie de ato mágico, em um espaço puro, onde todo gesto é possível, e todo o jogo nasce limpo. ${ }^{3}$

\footnotetext{
${ }^{1}$ Fala do personagem O Poeta, na peça A morta. Oswald de Andrade, São Paulo, Globo, 2005, p. 196.

${ }^{2}$ Eudinyr Fraga, O simbolismo no teatro brasileiro. São Paulo, Art e Tec Editora, 1992, p.93.

${ }^{3}$ Ruggero Jacobbi, $O$ espectador apaixonado. Porto Alegre, Curso de Arte Dramática da Faculdade de Filosofia, URGS, s/d, p.62.
} 
Nota-se, no entanto, que desde as produções em francês, Oswald de Andrade já não constrói peças facilmente "encenáveis". Leur âme teve somente a primeira cena do $2^{\circ}$ ato lido pela companhia francesa de Lugné Poe, em 1916, no Teatro Municipal de São Paulo, sem grandes repercussões. E, no mesmo ano, Mon coeur balance teve leitura na redação de A cigarra, "para a qual foram convidados amigos dos autores e representantes da imprensa”. ${ }^{4}$ Os jornais publicaram alguns comentários acerca dessa leitura, entre eles o de uma leitora, que assina Yayá Garcia, e que se mostra descontente com o fato de os autores pretenderem "lançar o ridículo sobre a sociedade que freqüenta o Guarujá, pintando-a como uma aglomeração de gente fútil”. ${ }^{5}$ Ou seja, mesmo sem grandes subversões estilísticas, o texto possuía feição diferenciada, se visto ao lado das produções teatrais bem recebidas.

As mulheres, por exemplo, personagens centrais nessas primeiras peças, estão longe das mocinhas apresentadas nos palcos brasileiros. Para efeito de análise comparativa, podemos tomar Rosinha, personagem de Flores de sombra, analisada no capítulo 2 desta tese, como modelo feminino intensamente aplaudido entre nós. A peça de Cláudio de Souza, que estreou na cidade de São Paulo no dia 22 de dezembro de 1916, mesmo ano de publicação de Mon coeur e Leur âme, já no dia 30 de dezembro, em publicidade impressa, “informava que dezesseis mil e cinco pessoas haviam aplaudido o espetáculo”. ${ }^{6}$

Marcela e Natália, protagonistas das peças de Oswald, são figuras excêntricas desapegadas da instituição familiar. Marcela, de Mon coeur é jovem e solteira, possui um passado desconhecido que lhe dá um tom misterioso, confessa que seu coração balança entre dois amigos, Gustavo e Luciano. Este último, o mais velho, ao ver que Gustavo encontra-se completamente apaixonado, opina acerca da personalidade da moça: "Marcela não é uma simples dona de casa, nada disso, Gustavo! Não! Ela não é mulher para você!”. Já Natália, de Leur âme é casada com George, por quem se declara apaixonada, mora num palacete em Higienópolis e tem um amante, Gastão. Os dois homens, apaixonados por Natália, são amigos e se exasperam, cada um por seu turno, ante a impossibilidade de

\footnotetext{
${ }^{4}$ Sábato Magaldi, O teatro de Oswald de Andrade. Tese de doutoramento em Literatura Brasileira. Faculdade de Filosofia, Letras e Ciências Humanas da Universidade de São Paulo, 1972, p.56.

${ }^{5}$ Idem, p.58.

${ }^{6}$ Sábato Magaldi e Maria Tereza Vargas, Cem anos de teatro em São Paulo (1875-1974). Editora SENAC, 2001, p.83.

${ }^{7}$ Oswald de Andrade e Guilherme de Almeida Prado, Obras completas: Mon coeur balance, Leur âme. São Paulo, Globo, 1991, p.38
} 
prender a mulher amada. "Eles podem ter seu corpo, mesmo seu coração, mas não sua alma". 8

No final das duas histórias, as mulheres somem e restam os homens amargurados e saudosos. Marcela afasta-se quando percebe que precisa escolher entre um dos dois pretendentes. Natália vai embora, abandonando tanto o marido quanto o amante, parte em viagem com um caixeiro viajante, levando consigo uma das filhas, a caçula. Marcela e Natália fogem, “já que para elas é a única solução nesses ambientes rarefeitos em que só as duas mulheres têm capacidade de ação". ${ }^{9}$ As peças terminam com a lembrança dos homens acerca dessas mulheres que se foram e que destoam dos modelos de boa moça e esposa exemplar, legitimados através de peças endossadas pela crítica do período.

Na segunda fase de sua dramaturgia, o que significa mais especificamente a produção teatral realizada após os manifestos modernistas - o Manifesto Antropófago (1928) e a Revista de Antropofagia (1928-1929), além dos romances Miramar (1924) e Serafim Ponte Grande (1933) -, os textos de Oswald já não respeitam nenhum tipo de convenção. Elementos cênicos próprios à teatralidade brasileira então em voga - aspectos dramatúrgicos retirados da comédia de costumes, do melodrama, do teatro de tese - surgem problematizados na dramaturgia oswaldiana, que coloca especialmente em questão lances da nossa comédia dramática, hegemônica no período. As referências próprias à forma dramática burguesa, como a menção aos personagens típicos das comédias, surgem descontextualizadas, em estado de tensão, em crise, desprovidas de lógica dramática, de avanço linear, como uma teatralidade às avessas.

É nítida a aspiração de obter novas relações entre o palco e platéia, assim como a tentativa de superar o teatro ilusionista tradicional. Só quem conhece o convencionalismo do teatro brasileiro daquele tempo pode avaliar o avanço audacioso dessas obras. ${ }^{10}$

Uma teatralidade muito distante em suas soluções formais dos espetáculos apresentados no país naquele momento histórico, apoiada em invenções que entrelaçam variadas e distintas linguagens, gêneros e referências cênicas e literárias. Um teatro que se

\footnotetext{
${ }^{8}$ Eudinyr Fraga, obra citada, p.92.

${ }^{9}$ Idem, p.94.

${ }^{10}$ Anatol Rosenfeld, Prismas do teatro. São Paulo, Perspectiva, 1993, p.151.
} 
afasta da forma dramática tradicional, vetado em sua possibilidade de encenação justamente por seu radicalismo, mas efetivado como produção teatral no modo próprio de recepção e de recusa a que foi submetido em seu tempo.

A modernidade em Oswald de Andrade é evidente, porém a sua contundência se acentua quando pensamos na especificidade de suas propostas, no diálogo que a forma oswaldiana trava com cada elemento conservador que marca o teatro brasileiro do período. Por isso a importância de levá-lo de volta como concretização artística de seu tempo, para o momento em que foi escrito, como tentativa frustrada dos anos 1930, como sonho sufocado no calor das primeiras décadas do século $\mathrm{XX}$, e não como um teatro, sem traumas anteriores, efetivado na década de 1960.

O primeiro intento que foi montar $O$ homem e o cavalo pelo Teatro da Experiência, de Flávio de Carvalho, deu no resultado conhecido. A polícia não se contentou em proibir a representação, mas fechou o teatro. Depois disso vi com esperança que Álvaro Moreyra pretendia representar a mais viável das minhas peças, $O$ rei da vela que chegou a ser anunciada nos cartazes do Teatro Boa Vista, em S. Paulo. Mas Álvaro foi adiando o espetáculo e afinal o retirou completamente de qualquer cogitação de montagem. Soube muito mais tarde que a ilustre canastra Itália Fausta, que exercia grande influencia na Companhia, ameaçou retirar-se da mesma caso a minha peça fosse somente ensaiada. Doutra feita deu-se o curioso caso com Procópio. Este fez a leitura da mesma peça perante um grupo, afirmando que ia representá-la. Em meio do $2^{\circ}$ ato teve um ataque de histeria e jogou os originais para o alto berrando: Isto também já é demais! ${ }^{11}$

A cena moderna de Oswald de Andrade se constrói em relação com os gêneros que dominavam a cena no Brasil à época: o teatro de revista, a ópera, e, especialmente, o drama burguês, tal como se efetivou entre nós, isto é, sob a forma da comédia de costumes. O diálogo com essa forma dramática, e a superação da mesma, merece atenção especial, já que em nossos palcos a aclimatação dos procedimentos da engrenagem dramática bemfeita, da defesa dos valores da burguesia, da representação do mundo privado, próprios do drama, se estabeleceu de maneira também específica, reiterando, a comédia de costumes.

\footnotetext{
${ }^{11}$ Oswald de Andrade. In: Sérgio Ricardo de Carvalho Santos, O drama impossível. Tese de doutoramento em Literatura Brasileira. Faculdade de Letras e Ciências Humanas da Universidade de São Paulo, 2002, p.213.
} 
Assim, torna-se fundamental, para analisar os lances modernos em Oswald, considerar que, em sua produção teatral, o autor dialogava com o padrão estético burguês tal como este se configurava em nosso país, e não com um modelo distante e pré-concebido de forma dramática, esperando encontrar por aqui o mesmo modo de efetivação, e de soluções modernas, próprias às experiências européias.

Como apontamos anteriormente, os registros cômicos de representação apareciam de maneira hegemônica na cena teatral brasileira e participavam, de maneira marcante, da difícil transposição do drama para uma sociedade como a nossa. As comédias se estruturavam através do modelo das peças bem-feitas, isto é, incorporavam os princípios do drama fechado, com estrutura bem encadeada e voltada para discussões no âmbito da vida privada. E representavam entre nós a constituição do drama burguês, em chave cômica.

A fim de reconhecermos essas comédias dramáticas podemos pensar no Gênero Trianon que predominou entre nós durante os anos de 1920 e 1930 e agradava especialmente “a fina flor da sociedade”. As comédias do Trianon, que devido ao reconhecimento da crítica e ao sucesso de bilheteria alcançado, chegaram a ser festejadas como o momento de nascimento do teatro brasileiro, eram filhas diretas das engrenagens da dramática bem-feita e sem o riso "baixo” do picadeiro.

Da mesma maneira - mas se colocando de forma contrária ao teatro aplaudido em nossos palcos - as experiências modernas surgidas por aqui apareciam também marcadas por registros cômicos. Em busca da superação desse teatro, Oswald constrói a sua dramaturgia, e as suas respostas, como já sublinhamos, não podiam se dar com as mesmas características do teatro moderno estabelecido por autores europeus. É preciso partir de alguns pontos gerais dos postulados modernos, porém encontrar o moderno específico, tal como efetivado nas obras desse autor, em face do contexto artístico e social com o qual dialoga.

\section{Devorando as convenções.}

Em O rei da vela, as convenções teatrais, tão bem trabalhadas nas comédias de costumes, aparecem como elementos conhecidos, deglutidos e, propositalmente, jogados fora. Os assuntos extrapolam a discussão do mundo privado: a família é um conjunto de 
seres desesperados, cada qual tentando salvar a própria pele. Os fatos históricos adentram a peça (João Candido e a revolta dos marinheiros de 1910), personagens reais desfilam no jogo de cena (Paschoal Carlos Magno, criador do Teatro do Estudante) e personagens de outras obras servem como referência para a construção dos tipos apresentados (Aída, de Verdi e Lady Windermere, de Oscar Wilde). São elementos que paralisam o encadeamento da narrativa, apresentam o contexto histórico - presente e passado -, explodindo a forma rigorosa do drama.

As personagens das comédias brasileiras, presentes ainda em Mon coeur balance e Leur âme - o fazendeiro e a filha única que procura um marido, a solteira espevitada, a moça que procura o amor - já não sobrevivem de maneira isenta de críticas nas peças de 1930. Ou melhor, aparecem destroçados. O pai de família, o casal de jovens noivos, as senhoras de meia idade, a moça solteira e o fazendeiro, estão em $O$ rei da vela, porém "saem do panelão deformados, caricaturados, tortos, caolhos, capengas, carecas, desdentados". ${ }^{12}$

Se tentamos contar o enredo de $O$ rei da vela, como é possível fazer com Leur âme e Mon coeur balance, não obtemos êxito. A estrutura da obra dificulta a tarefa de organizála como síntese. Uma descrição em poucas linhas - que se trata de um agiota e fabricante de velas, que pretende casar com Heloísa, filha de um cafeicultor decadente, mas que se vê roubado pelo secretário e, no último ato, vendo-se à falência, comete suicídio, nos braços de sua futura esposa, a qual por fim casa-se com o seu rival - não consegue narrar o que de fato acontece na peça. Para contar o enredo precisamos, ao mesmo tempo, esclarecer as opções formais. Pois o sentido do enredo só se efetiva em tensão com as demais soluções formais propostas pelo autor, que o desagregam e o inviabilizam enquanto síntese representacional, e o explodem em ampla possibilidade de sentidos a serem produzidos pelo espectador.

Desde a primeira cena, as indicações do texto já revelam o seu rompimento definitivo com o modelo instituído pelo realismo cênico praticado comumente entre nós. A sala de visitas das comédias some, em seu lugar surge o "Escritório de Usura de Abelardo e Abelardo”, na cidade de São Paulo, onde pela “ampla janela entra o barulho da manhã da

\footnotetext{
${ }^{12}$ Ruggero Jacobbi, obra citada, p.63.
} 
cidade e sai o das máquinas de escrever da ante-sala”. ${ }^{13}$ É possível também observar outros elementos relevantes presentes no cenário: uma porta de ferro à direita correndo sobre rodas, “deixando ver no interior as grades de uma jaula”. Também no escritório aparece um prontuário com gavetas que possuem rótulos: "Malandros - Impontuais - Prontos Protestados". ${ }^{14}$ Na outra divisão: "Penhoras - Liquidações - Suicídios - Tangas”. ${ }^{15}$ Em cena encontram-se Abelardo I, O Cliente e, em seguida, Abelardo II que surge vestido como um domador de feras.

O Cliente, que, como indica rubrica, está “embaraçado, o chapéu na mão, uma gravata de corda no pescoço magro" ${ }^{\text {, }}$, implora para que Abelardo I lhe faça um preço razoável para que possa liquidar sua dívida, já que somente de juros já lhe entregou duas vezes o valor da soma adquirida. $\mathrm{O}$ agiota nega o pedido e termina o encontro chamando o secretário, Abelardo II, e dando-lhe ordens para executar o indivíduo. Na jaula, outros clientes esperam para serem atendidos, porém a entrada dos outros clientes é adiada e a cena é interrompida pela fala de Abelardo I:

Abelardo I - Não faça entrar mais ninguém hoje, Abelardo.

Abelardo II - A jaula está cheia...seu Abelardo!

Abelardo I - Mas esta cena basta para nos identificar perante o público. Não preciso mais falar com nenhum dos meus clientes. São todos iguais. Sobretudo não me traga pais que não podem comprar sapatos para os filhos... ${ }^{17}$

O abandono da sequência dramática opera uma tematização explícita dos procedimentos da construção da cena teatral. Ou seja, quando Abelardo I interrompe a cena, proclamando que não é necessário que outros personagens entrem, para que todos os presentes sejam reconhecidos ou identificados, para que a cena seja compreendida, o autor destrói a ilusão teatral, convida o espectador a adotar uma postura crítica diante do que está

\footnotetext{
${ }^{13}$ Oswald de Andrade, O rei da vela. São Paulo, Globo, 2003, p.37.

${ }^{14}$ Idem, p. 37.

${ }^{15}$ Idem, p.37.

${ }^{16}$ Idem, p.38.

${ }^{17}$ Idem, p.43.
} 
sendo apresentado. “A platéia pensa imediatamente, movida pelo convite à crítica, feito por Abelardo". ${ }^{18}$ Através de um procedimento moderno, o autor/encenador propõe um novo olhar para o que está sendo narrado. Atitude extraordinária no teatro brasileiro do período, diga-se de passagem.

A cena prossegue entre os dois Abelardos, ficamos sabendo então que Abelardo I pretende se casar com Heloísa, pois esta, pertencendo a uma “família de brasões”, mesmo arruinada financeiramente, representa um bom negócio. O casamento como negócio é assunto antigo nas comédias brasileiras, no entanto, o retrato de certas práticas oriundas de uma sociedade feudal construído nessas comédias, como observamos anteriormente, não se dava em tom eficientemente crítico. Eram apontados e normalizados, como se a representação legitimasse a prática ao invés de questioná-la. Aqui, a questão do casamento como negócio aparece como uma ferida aberta. O autor aproveita para, através da fala de Abelardo II, classificar a única forma comumente aceita de teatro no Brasil: “a burguesia só produziu um teatro de classe. A apresentação da classe”. ${ }^{19}$ Aqui o termo se refere tanto a um teatro de uma única classe quanto a um teatro bem comportado, ao qual o teatro da descompostura, como este que está acontecendo diante dos nossos olhos, se coloca em oposição. É Abelardo II quem esclarece a proposta formal do autor: “Hoje evoluímos. Chegamos à espinafração", ${ }^{20}$

Após observar como andam as contas: "Estamos no vinagre",21, diz Abelardo II, e os despejos efetivados devido ao não pagamento de dívidas, Abelardo I ordena para que o secretário abra a porta de ferro. Através da grade podemos enxergar outros clientes que imploram novos empréstimos ou prazos maiores para saldar suas dívidas. A cena dos clientes, interrompida anteriormente, é, então, retomada. Abelardo II ameaça-os com um chicote e um revólver. As vozes dos imigrantes, elementos novos na população da cidade, aparecem e desmascaram a figura do dono da empresa.

Um italiano - Pamarona! Momanjo isto capitalista!

\footnotetext{
${ }^{18}$ Sábato Magaldi, o teatro de Oswald de Andrade. Tese de doutoramneto em Literatura Brasileira. Faculdade de Letras e Ciências Humanas da Universidade de São Paulo, 1972, p.68.

${ }^{19}$ Oswald de Andrade, obra citada, 2003, p.44

${ }^{20}$.Idem, p.44.

${ }^{21}$ Idem, p.45.
} 
Uma francesa - Sale cochon! Si c'est possible! Com!

Um russo branco - Svoloch!

Um Turco - Jóge paga bateca! Non izacuta Jóge...

As vozes (Em coro) - Assassino!

Abelardo I - Feche! Atire! ${ }^{22}$

Abelardo II dá um tiro para o ar e fecha porta de ferro. Após a porta fechada, ouvimos vozes femininas que lamentam:

As vozes (Abafadas) - Cão! Rei da Vela! Pão duro!

Uma voz de mulher - Meu marido bebeu estricnina!

Outra - Minha mãe tomou lisol!

Outra - Meu pai se jogou do Viaduto!

Abelardo I - Lisol! Estricnina! Viaduto! É do que vocês precisam, canalhas! $!^{23}$

O suicídio por falta de pagamento de dívidas, muito comum em plena crise econômica mundial, finaliza a apresentação dos clientes. De modo que o final da cena, ressaltado pelos elementos circenses presentes no cenário e no figurino - a jaula, o chicote, a roupa de domador de feras usada por Abelardo II -, e acentuado pela ironia contida na encenação em potencial anunciada através das rubricas, coloca em tensão a tragicidade da situação social apresentada.

A quinta cena, ainda no primeiro ato, ocorre entre Abelardo I e A Secretária, de nome Aída. Aparentemente é uma cena clássica de comédia, sem maior interesse, já que se trata de um patrão assediando sua secretária enquanto esta escreve uma carta a seu pedido. Porém, quando parte para o ataque, Abelardo I sussurra: “Dona Aída... Aída loira... Aída de Wagner. Como é? Não precisa de um Radamés? (...) Que tranças!... Eu acabo me

${ }^{22}$ Idem, p.49.

${ }^{23}$ Idem, p.49 
enforcando nessas tranças!... Deixa?” ${ }^{24} \mathrm{Na}$ investida do patrão, fazendo menção ao compositor da ópera, aparece uma pista errada. A personagem creditada a Wagner é na verdade de Verdi, ópera bastante representada nos palcos brasileiros do período.

Originalmente a personagem da ópera é uma princesa etíope, portanto negra. Mas se Oswald resolveu brincar e colocar Wagner no jogo, com toda a carga ariana atribuída a ele naquele momento histórico, a moça só poderia ser loira, e de tranças enormes, para não deixar dúvidas (nas gravuras e fotografias da época elas eram assim). Na ópera ela se apaixonou por Radamés, o comandante do exército egípcio que travava uma guerra contra a Etiópia. Se a princesa se apaixonou por seu inimigo, nada mais coerente do que a secretária se apaixonar por seu patrão, que a explora e a ameaça. ${ }^{25}$

A falsa alusão ao autor da ópera encontra sentido na desautomatização da percepção proposta a todo o momento pelo autor. As referências, já que misturadas, ganham sentido diverso daquele apontado inicialmente, instaurando assim um jogo paródico que avança desorganizando a cena, concedendo-lhe camadas espessas de significados. Para ampliarmos a compreensão do uso da paródia nas obras dramáticas de Oswald de Andrade, podemos observar o mesmo procedimento adotado em seus romances.

Um dos principais recursos, no Miramar, é a paródia (da qual se valeram também Joyce e Thomas Mann, as duas grandes admirações de Oswald de Andrade no romance moderno). Paródia que não deve ser necessariamente entendida no sentido de imitação burlesca, mas inclusive na sua acepção etimológica de canto paralelo. (...) A paródia, enquanto “canto paralelo”, acerca-se tanto da idéia bakhtiniana de dialogismo (...) como da noção de inter (entre)-textualidade kristeviana. ${ }^{26}$

Em Oswald de Andrade, o canto paralelo que atravessa a obra intensifica os aspectos perceptivos, tira o leitor de seu mundo restrito, deixando à mostra as diversas

\footnotetext{
${ }^{24}$ Idem, p.52.

${ }^{25}$ Rina Signer, Ingredientes para uma nouvelle cuisine: o rei da vela ao molho de Ubu Rei. Tese de doutoramento apresentada ao Departamento de Letras Modernas da Faculdade de Letras e Ciências Humanas da Universidade de São Paulo, 2000, p.134.

${ }^{26}$ Haroldo de Campos, Deus e o diabo no Fausto de Goethe. São Paulo, Perspectiva, 2005, p.74.
} 
possibilidades de leitura. A paródia utilizada em O rei da vela surge "criando uma experiência nova, não mais pelo reconhecimento do objeto, mas por uma visão singular, insólita dele”. ${ }^{27}$ Assim como na referência enganosa à personagem de Verdi, o jogo paródico não surge de maneira horizontal, pronto a facilitar e restringir o ato do espectador ao mero entendimento da fábula, mas provocando-o a efetivar uma leitura transversal, relacionado os variados elementos de significação participantes da cena polifônica. O jogo de linguagem se revela como tal, deixa patente o objetivo do autor, tanto de deixar à mostra as amarras da dramaturgia, o processo de construção do texto, quanto de explicitar o ato do espectador, que aponta para a desautomatização da recepção. A paródia aparece como o “meio natural para o desnudamento do processo". ${ }^{28}$

Na cena seguinte, que mostra o encontro entre Abelardo e Heloísa, podemos observar novamente o recurso paródico utilizado pelo autor. Os nomes escolhidos para o casal trazem à tona, como primeira referência, a conhecida e trágica história dos amantes do século XII. Desde a fala inicial entre os dois, contudo, qualquer possibilidade de leitura romântica do encontro vê-se inviabilizada:

\footnotetext{
Abelardo I - Você! Meu amor! Na hora do expediente!

Heloísa - O nosso casamento é um negócio...

Abelardo I - Por isso vieste de Marlene? ${ }^{29}$
}

O Abelardo do acontecimento medieval era teólogo e filósofo escolástico francês, e amava profundamente Heloísa, sua aluna, com quem manteve um caso de amor secreto. Quando o tio de Heloísa, o cônego Fulbert, descobriu o romance, afastou o casal, ordenou que castrassem Abelardo e mandou a sobrinha para um convento. Mesmo afastados mantiveram-se próximos, através de cartas afetuosas, até a morte. Uma história de amor totalmente oposta aos motivos apontados para o casamento entre Abelardo e Heloísa de $O$

\footnotetext{
${ }^{27}$ José João Cury, O teatro de Oswald de Andrade: ideologia, intertextualidade e escritura. São Paulo, Annablume, 2003, p.41.

${ }^{28}$ Haroldo de Campos, “Serafim: um grande não livro”. In: Oswald de Andrade, Serafim Ponte Grande. São Paulo, Globo, 2007, p.23.

${ }^{29}$ Oswald de Andrade, obra citada, 2003, p.54.
} 
rei da vela, nesse caso uma questão de negócio. A sobreposição de narrativas desloca a compreensão esperada e provoca o leitor a efetivar um ato produtivo.

A roupa utilizada nesta cena por Heloísa - “vieste de Marlene?” - indicia outra proposta artística marcadamente moderna utilizada por Oswald: a fluidez dos signos apresentados. Um elemento de cena que parece apontar para um determinado sentido pode ser contrariado mais tarde no percurso da obra, de modo que o signo se torna flexível, subvertendo a lógica linear e abrindo os recursos cênicos para outras produções possíveis de sentidos. O que traz problemas de leitura e de análise para a produção de Oswald, que é freqüentemente cobrado por não manter a lógica dramática esperada. E faz com que as invenções do autor sejam indevidamente tomadas como falhas dramatúrgicas. Aspecto que lhe valeu críticas no período e que colabora, ainda hoje, para o veto à efetivação moderna de sua produção teatral.

Oswald de Andrade opera com a materialidade do elemento cênico, que precisa ser manipulado inventivamente pelo leitor, que, deste modo, define seus potenciais sentidos à medida mesmo que processa o ato de leitura. O sentido não está fixado, mas tem necessária mobilidade, pronto para ser (re)modelado pelo leitor. Procedimento este que é retomado por experiências teatrais realizadas desde as últimas décadas do século $\mathrm{XX}$, que reelaboram e, muitas vezes, radicalizam justamente as propostas dos autores da vanguarda do início do século XX, como as de Oswald.

O interesse sistemático aqui referido se coloca sobre um modo de utilização modificado dos significantes do teatro, em que a mediação de conteúdos claramente delimitados do ponto de vista semântico não é prioritária. Nós preferimos geralmente o termo significante em lugar de signo, pois aquele acentua a materialidade exterior em lugar da representação mental. ${ }^{30}$

O traje masculino de Heloísa encontra referência nas roupas usadas por Marlene Dietrich, atriz alemã que usava calças compridas e que nesse momento fazia sucesso com a personagem Lola, no filme $O$ anjo azul (1930), de Josef Sternberg, no qual a atriz interpretava uma cantora de cabaré. A caracterização à Marlene é comumente lida como

\footnotetext{
${ }^{30}$ Hans-Thies Lehmann, Le théâtre postdramatique. Paris, L'Arche, 2002, p.12.
} 
indicação de homossexualidade para a personagem de $O$ rei da vela, já que reiterada pelo fato de na primeira cena Abelardo I se referir à futura esposa como Heloísa de Lesbos. Porém, como no segundo ato Heloísa, e também a sua irmã, inicialmente chamada de João dos Divãs, aparecem desfazendo a referência inicial, o autor acabou criticado por falta de coerência na construção da personagem.

Desenvolvendo uma pista de Décio de Almeida Prado, vale a pena observar o tratamento dado à Heloísa e aos irmãos, Perdigoto, Totó e Joana. Estranhamente, o dramaturgo só foi coerente na exposição dos homens. Perdigoto é facista e como tal se comporta (...). Totó Fruta do Conde, como o apelido indica é o homossexual assumido, em crise porque perdeu o seu último namorado (...). Já Heloísa e Joana, apresentadas por apelidos que dispensam interpretação - Heloísa de Lesbos e João dos Divãs - contrariam pelo comportamento essa determinação, como observou Décio de Almeida Prado. A primeira, cujo noivado e atitudes não chegam propriamente a desmentir o dramaturgo (ela deve entrar em cena vestida de homem), no mínimo contraria o modo como foi concebida por seu procedimento "de camaradagem sexual" com o americano desde a abertura do segundo ato e, mais ainda, pela reação melodramática à notícia da ruína e depois o suicídio do noivo (a rubrica indica-lhe um comportamento "lastimoso e soluçante" em todo o terceiro ato; ela propõe romanticamente a Abelardo que fujam para "recomeçar”). ${ }^{31}$

Acontece que o casal de amantes medieval, mencionado inicialmente como referência para a construção de Oswald, indica também outras e menos reconhecidas características para Heloísa:

A Heloísa original (1101-1164) fugia do padrão de mulher submissa, pois era inteligente e culta, dominando o latim, o grego, a literatura clássica e a pagã, numa época em que isso não existia entre as mulheres. $^{32}$

Basta observarmos com mais atenção para notarmos que a postura da Heloísa fictícia da década de 1930, “um ser mal-educado nos pensionatos milionários da Suíça”33,

\footnotetext{
${ }^{31}$ Iná Camargo Costa, A hora do teatro épico no Brasil, São Paulo, Paz e Terra, 1996, p.160.

${ }^{32}$ Rina Signer, obra citada, p.126.
} 
pode bem ser relacionada ao dado histórico de emancipação presente na Heloísa real, do século XII. O aspecto masculino das roupas de Heloísa em $O$ rei da vela deixava a personagem com a expressão da mulher que se opõe ao modelo ideal imposto às mulheres do seu tempo. Se lembrarmos a imagem desenhada para a mulher nesse período, através de revistas e demais publicações - mulheres que precisavam aprender a ser boas esposas antes de qualquer outra coisa -, podemos nos aproximar de qual modelo a Heloísa de Oswald de Andrade, inspirada na Heloísa do século XII, se contrapunha. Era comum no Brasil dos anos 1920 e 1930, as revistas ensinarem às mulheres como deviam se comportar diante dos maridos; na Revista Feminina, de outubro de 1924, por exemplo, a publicação do “decálogo da esposa” apontava atitudes fundamentais que deviam ser adotadas pelas mulheres de classe:

I - Ama teu esposo acima de tudo na terra e ama o teu próximo da melhor forma que puderes; mas lembra-te de que tua casa é de teu esposo e não do teu próximo; (...)

III - Espera teu esposo com teu lar sempre em ordem e o semblante risonho; mas não te aflijas excessivamente se alguma vez ele não reparar nisso; (...)

Lembra-te sempre que te casaste para partilhar com teu esposo as alegrias e as tristezas da existência. Quando todos o abandonarem fica tu a seu lado e diz-lhe: Aqui me tens! Sou sempre a mesma; (...)

$\mathrm{X}$ - Se teu esposo se afastar de ti, espera-o. Se tarda em voltar, espera-o; ainda mesmo que te abandone, espera-o! Porque tu não é somente a sua esposa; és ainda a honra de seu nome. E quando um dia ele voltar há de abençoar-te. ${ }^{34}$

Ficava reservada para a mulher a função de encarnar o ideal de pureza e submissão combinado com as novas expectativas burguesas de gerência do lar e ainda apresentar-se em sociedade como companheira ideal. Através de artigos como esse, podemos perceber com que dados históricos o autor trabalhava. Se a postura moderna dessa personagem pode ser mais claramente definida, se podem parecer exagerada suas roupas masculinas e a

\footnotetext{
${ }^{33}$ Oswald de Andrade, obra citada, 2003, p. 60.

${ }^{34}$ Marina Maluf e Maria Lúcia Mott. Recônditos do mundo feminino. In: História da vida privada no Brasil. Vol.3, Companhia das Letras, 2006, p. 395.
} 
menção ao homossexualismo por toda a parte em $O$ rei da vela, não menos exagerada era a imagem de submissão oferecida à mulher naquela sociedade. As notícias desse modelo de esposa podem ser notadas tanto nos conselhos apresentados pelo decálogo citado acima, quanto nas comédias de costumes que ocupavam os nossos palcos e defendiam modelo semelhante.

A especificidade da realidade brasileira, assim como as características de nosso drama burguês em chave cômica, participavam das opções estéticas de construção de personagens e situações em $O$ rei da vela. A Heloísa desenhada por Oswald, além de se vestir à maneira de Marlene Dietrich, fuma junto com a tia e troça das imprudências de seu futuro esposo, com quem comenta: “Outro flerte! Ontem era a mamãe! Hoje tia Poloca. Quantos chifres você me põe por hora, Abelardo?”.35

O cigarro na mão de uma mulher nesse período, associado com freqüência a contextos de sofisticação, liberdade, ousadia e prazer, se torna símbolo imediato da modernidade. $^{36}$ "O começo da libertação feminina acrescenta a Heloísa um aspecto másculo, nova caricatura da tradicional feminilidade”. ${ }^{37}$ Além do que, a não sustentação da opção sexual de Heloísa do primeiro para o segundo e terceiro atos pode, ao invés de parecer defeito, exemplificar o procedimento básico de construção e desconstrução de sentido, proposto por Oswald de Andrade.

Em Oswald, essa inversão paradigmática ocorre já ao nível dos nomes das personagens: são signos mutantes, muitas vezes contraditórios (a origem contradiz sua postura no decorrer da ação), indiciam a ação, mas a contradizem. São também signos de humor, muito mais apelidos que nomes próprios. $^{38}$

Não se pode esperar de Oswald de Andrade uma coerência dramática, calcada na linearidade psicológica dos personagens, se é justamente contra essa coerência e esse padrão estético que ele se volta. Nos aspectos dramatúrgicos em que o leitor busca o drama,

\footnotetext{
${ }^{35}$ Idem, p.74.

${ }^{36}$ Ver imagem na página seguinte.

${ }^{37}$ Sábato Magaldi, Teatro da ruptura: Oswald de Andrade, São Paulo, Global, 2004, p. 88.

${ }^{38}$ Carlos Gardin, O teatro antropofágico de Oswald de Andrade: da ação teatral ao teatro de ação. São Paulo, Annablume, 1995, p.150.
} 


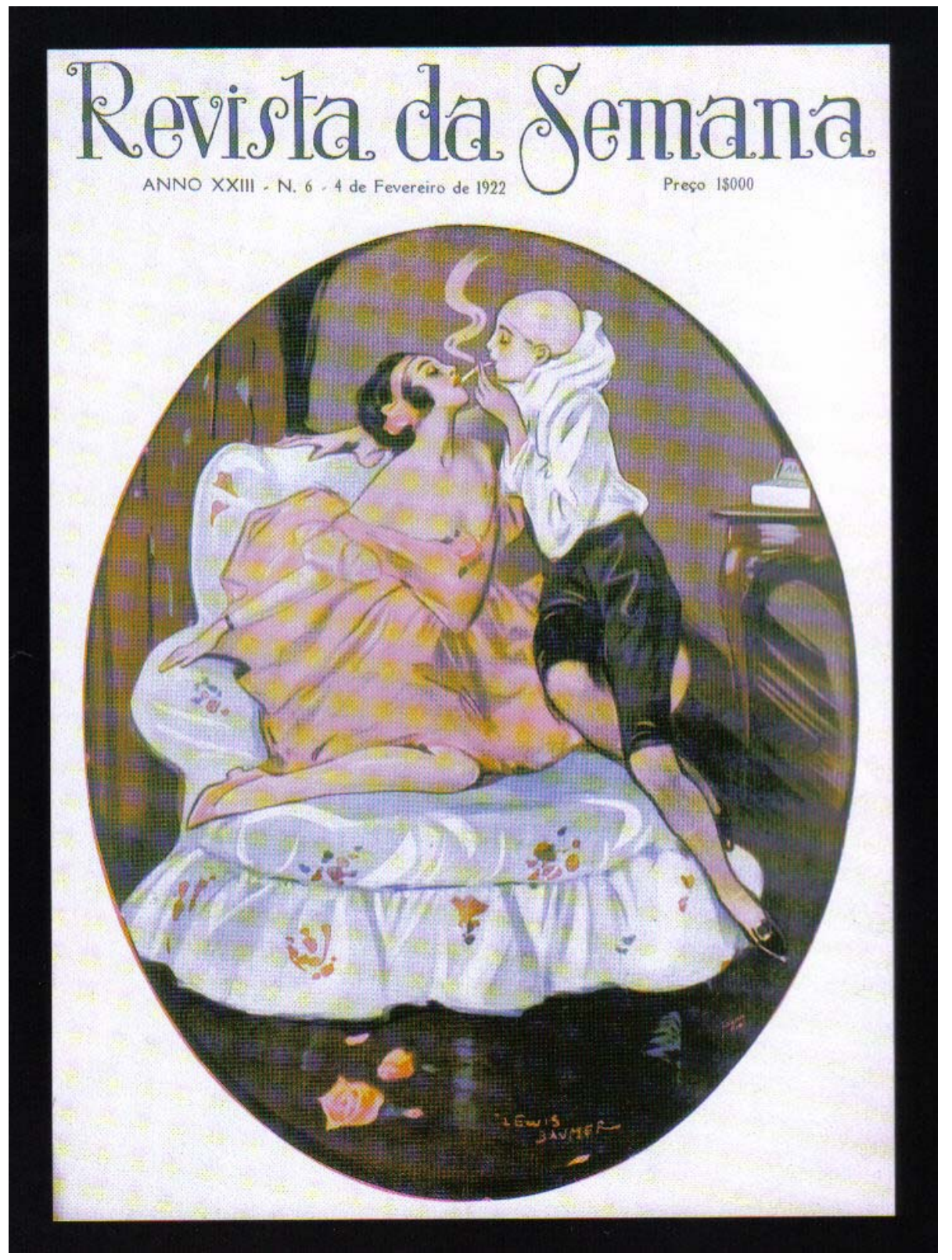


Oswald oferece a problematização dessa (ou a recusa a essa) forma artística. A construção inicial de Heloísa - e aqui podemos lembrar os recursos de quebra com o romance de cavalaria utilizados no Dom Quixote, de Cervantes, citados anteriormente -, cria uma expectativa de coerência psicológica da personagem que será desmontada a seguir. Este é um dos procedimentos utilizados pelo autor para colocar em questão a pertinência da forma dramática em voga no período.

\section{Vozes dissonantes.}

No segundo ato, temos a apresentação das personagens componentes da família de Heloísa. A técnica do desfile utilizada por Oswald de Andrade na construção de $O$ rei da vela, em que "terminado o papel ilustrativo de uma figura, surge outra, para acrescentar nova dimensão ao entrecho”39, parece levada ao extremo. “Como nos espetáculos circenses, o segundo ato nada mais é que o detalhamento desse desfile”. ${ }^{40}$

A técnica do desfile pode ser tomada como procedimento semelhante ao utilizado por Martins Pena, quando construía cenas em que num mesmo local as personagens da história apareciam, uma a uma, como se desfilassem suas principais características. As comédias de Pena, como se sabe, eram consideradas inferiores, se comparadas às comédias realistas francesas, que em meados do século XIX invadiam a nossa cena, através do Teatro Ginásio Dramático, no Rio de Janeiro. Como apontamos anteriormente, as comédias francesas eram, naquele momento, consideradas modelos para a construção do teatro nacional, enquanto que as de Martins Pena eram criticadas pelo aspecto de farsa, falta de linearidade e presença de cenas soltas.

Pois bem, dialogando com a tradição farsesca da comédia de costumes e também com a representação em quadros do teatro de revista, Oswald de Andrade cria um segundo ato que não mais se localiza em São Paulo, local de trabalho, mas em uma ilha no Rio de Janeiro, local de prazer e descanso. As personagens atravessam a cena de maneira coreográfica:

\footnotetext{
${ }^{39}$ Idem, p.75.

${ }^{40}$ Iná Camargo Costa, obra citada, p.156.
} 
Pela escada, ao fundo, surgem primeiramente, em franca camaradagem sexual, Heloísa e o Americano. Saem pela direita. Depois, Totó Fruta-do-Conde, tétrico. Sai. Em seguida, d. Poloca e João dos Divãs. Saem. Depois, o velho coronel Belarmino, fumando um mata-rato de palha e vestido rigorosamente de golfe. Sai. Segue-lhe um par cheio de vida: d. Cesarina, abanando um leque enorme de plumas em maiô de Copacabana e Abelardo I com calças cor de ovo e camiseta esportiva. Permanecem em cena. ${ }^{41}$

A cena ganha sequência com os dois últimos personagens, Abelardo I e d. Cesarina, mãe de Heloísa. Os dois trocam galanteios, se valem de piadas grotescas que relacionam alimentos a símbolos fálicos, numa linguagem ambígua e sexualizada que lembra as graças do teatro de revista e do circo. Quando indagado pela sogra se não sente ciúmes de sua futura esposa, ao se colocar tão próxima do americano, Abelardo I retruca, quebrando com a forma descontraída inicial e representa, em moldes melodramáticos, uma cena de ciúmes entre um casal:

Abelardo I - (...) (Imita dramaticamente um casal em choque.) Diga Heloísa! Quem era aquele homem? - Eu, fui lá só para dar um recado. - Foste lá! Confessas! Entraste naquela casa, naquele antro! Traíste-me, perjura! - Ah! Meu amor, que desconfiança também, que injustiça! Um homem feio daquele! Eu fui lá só por causa do recado! - Maldita! Pum! Pum! (Ri) Oh! Oh! Ah! É isso? Essa ridicularia que divertiu e ensangüentou gerações de idiotas. É isso... O ciúme! ${ }^{42}$

O tiro que finaliza a cena de ciúmes e traição imaginada por Abelardo I era outra possibilidade muito comum concedida aos maridos traídos na sociedade brasileira daquele período. Em Uma flor de marido, de Armando Gonzaga, comédia que segue a linha da peça bem-feita, como referido anteriormente, a discussão acerca do assunto mostra-se através do personagem Comendador, ao dizer que uma peça que mostra traição sem morte no final não tem a menor graça. E da seguinte maneira defende o seu ponto de vista junto ao dramaturgo, outro personagem da peça com quem dialoga:

\footnotetext{
${ }^{41}$ Oswald de Andrade, obra citada, 2003, p. 65.

${ }^{42}$ Idem, p.71.
} 
Pois bem, não mate a esposa infiel. Faço-lhe essa concessão. Mas poupando-lhe a vida, não mate a sua peça. Já que não quer dar tiros, ponha-me, ao menos dois berros no final daquele ato. É preciso que o pano caia no meio da maior animação. Eu conheço as platéias... ${ }^{43}$

A mesma situação foi discutida em $O$ homem que marcha, de Benjamin Lima, peça analisada anteriormente, que buscou construir destino diferente ao casal de amantes, que não a morte anunciada pela traição. Na ocasião, vale lembrar, que houve quem se levantasse na platéia para chamar a peça de vergonha nacional e, que, por alegações semelhantes, esta peça teve premiação negada, em 1925, pela Academia Brasileira de Letras. Ou seja, tratava-se de um fato social comumente observado na vida e nos teatros da cidade. Porém, ao zombar do ciúme e da maneira como este assunto aparecia em nossos palcos, ridicularizando o exagero habitual dessas situações, Abelardo I não agrada sua espectadora. D. Cesarina, legítima representante da platéia habituada aos nossos dramas; ao contrário, ela mostra-se ofendida:

D. Cesarina (levantando-se) - Pois se o senhor não tem vergonha, seu Abelardo, eu tenho! Olhe este leque ! Este leque ainda é capaz de fazer muito estrago! (Deixa a rede).

Abelardo I - Compreendo! É o leque de Lady Windermere! $!^{44}$

Na última fala, de Abelardo I, aparece outra referência literária, que como uma espécie de legenda, nos convida a ampliar a compreensão, adentrando em outras camadas da mesma cena. A peça O leque de Lady Windermer, de Oscar Wilde, apresenta o lorde Windermere que tem um relacionamento amoroso com a mãe de sua esposa, sem saber da ligação familiar das duas. A esposa acreditava-se órfã. Em O rei da vela, Oswald se vale da narrativa de Wilde, mas tratando o que havia sido um erro casual, já que os personagens envolvidos não sabiam o que estavam fazendo, como uma bajulação atrevida. O rei da vela galanteia a sogra, matrona da aristocracia paulista, e é também galanteado por ela, sem

\footnotetext{
${ }^{43}$ Armando Gonzaga, Comédias. São Paulo, Livraria Teixeira, 1940, p. 35.

${ }^{44}$ Oswald de Andrade, obra citada, 2003, p. 71.
} 
maiores pudores. "E não foi a classe dela, a aristocracia, que jogou Oscar Wilde na prisão por moralismo?”. 45

A contínua utilização de referências - nos nomes dos personagens, nos fragmentos parodiados, nos fatos históricos - se estrutura como pistas deixadas pelo autor. A cena não conta com um motor interno, ao contrario, é por intermédio de associações com outras obras que a trama consegue se movimentar, obtendo, dessa maneira, um aspecto híbrido, de mosaico, de vozes dissonantes. O diálogo com outros estilos e autores, estabelecido de maneira direta ou indireta, permite que suas vozes e seus formatos se façam também presentes no ato artístico.

A paródia, entendida enquanto canto paralelo, texto que se afirma enquanto diferença, discurso que não esconde a voz do outro e nem a oprime, é em Oswald e seu teatro o procedimento básico para seu gesto teatral. Tudo está dito mas para ser re-dito. ${ }^{46}$

Para produzir sentido na leitura das cenas torna-se necessário seguir as pistas deixadas, mas exige-se também que o leitor/espectador realize as próprias associações. “A recepção se vê como diante de uma rede imensa onde discursos de várias épocas e várias sociedades se entrecruzam". ${ }^{47}$ A absorção de outros textos e a atenção voltada para o âmbito da recepção, em forma de convite criativo, revela-se como procedimento característico nas obras de Oswald de Andrade.

Para ampliarmos a idéia acerca das diversas camadas referenciais de $O$ rei da vela, podemos notar as características de Abelardo I, o protagonista. O mesmo personagem que aparece referenciado em Abelardo - teólogo francês apaixonado por Heloísa e também filósofo escolástico que "escandalizou a Igreja no século XII por defender uma doutrina que negava a existência de verdades universais” 48 e foi "considerado posteriormente pai do

\footnotetext{
${ }^{45}$ Rina Signer, obra citada, p.136.

${ }^{46}$ Carlos Gardin, obra citada, p.51.

${ }^{47}$ Idem, p.52.

${ }^{48}$ Rina Signer, obra citada, p.124.
} 
racionalismo"49 -, possui em seu nome outra referência, além desta, e que no decorrer da peça mostra-se tão relevante quanto a primeira. O palhaço Piolim chamava-se na verdade Abelardo Pinto, e era o ator inicialmente imaginado pelo dramaturgo para viver o protagonista de $O$ rei da vela. Piolim, importa ressaltar, era muito festejado e admirado, não somente por Oswald, mas pelos principais articuladores do modernismo entre nós.

A comicidade de Piolim evoca na gente uma entidade, um ser. E de tanto maior importância social que essa entidade converge para esse tipo psicológico geral e universalmente contemporânea do ser abúlico, do ser sem nenhum caráter predeterminado e fixo, do ser 'vai na onda' (...) Nesta ordem geral do ser humano, que parece criada pela inquietação e pelas enormes perplexidades deste fim de civilização, ser que nós todos profundamente sentimos em nós, nas nossas indecisões e gestos contraditórios, é que o tipo criado por Piolim se coloca também. Dentro de toda a deformação caricata, Piolim é um ser real, embora completamente anti-realista no sentido em que foram "Realistas” os Zolas, os Eças e os Aluísios de Azevedo. ${ }^{50}$

Os modernistas acompanhavam os espetáculos de Piolim que aconteciam no barracão de Alcebíades, no largo Paiçandu, em São Paulo. Os escritores e demais artistas que freqüentavam o circo admiravam-no “enquanto espetáculo pândego, representação criativa, manifestação da cultura popular”. ${ }^{51}$ Discutiam, em debates acalorados, a qualidade artística dos palhaços, tomando muitas vezes espetáculos circenses vistos em outros países como termo de discussão. Os palhaços europeus, como os irmãos Fratellini, eram freqüentemente citados. Mas a grande exaltação voltava-se mesmo para o talento cômico de Piolim. No dia 27 de março de 1929, dia do aniversário de Abelardo Pinto, alguns artistas e escritores, entre eles Alcântara Machado, Mário de Andrade e o próprio Oswald, ofereceram um almoço, que denominaram de "festim antropofágico"52 e no qual

\footnotetext{
${ }^{49}$ Idem, p.125.

${ }^{50}$ Mário de Andrade, apud Maria Augusta Fonseca, Palhaço da burguesia: Serafim Ponte Grande, de Oswald de Andrade e suas relações com o universo do circo. São Paulo, Editora Polis, 1979, p.35.

${ }^{51}$ Maria Augusta Fonseca, obra citada, 1979, p.32.

${ }^{52}$ Idem, p.32.
} 
anunciavam: "almoçaremos Piolim”. 53 A referência ao palhaço Abelardo, explicitada no nome dado ao protagonista e indicada nas alusões ao universo do circo presentes no cenário e figurino do primeiro ato, surge também na construção da dupla cômica formada por Abelardo I e Abelardo II.

Um dos procedimentos cômicos de Oswald é a duplicação de Abelardo, desdobrado em Abelardo I e Abelardo II (...). A comicidade está na semelhança e pequenas diferenças contribuem para reforças as semelhanças. São antagonistas completamente semelhantes. Este procedimento é bastante conhecido dos bons palhaços: eles se apresentam em dupla, numa certa medida são idênticos e em outra são diferentes. ${ }^{54}$

“O modelo clássico está na dupla Don Quixote - Sancho; esse pares são hoje correntes no circo , no teatro de saltimbancos e em outras formas cômicas." Abelardos podem ser observados através das oposições: patrão e empregado, malicioso e ingênuo, capitalista e socialista. Na dupla, o secretário pode ser visto como o clown mais esfarrapado, o que atrapalha os planos de seu companheiro surgindo em momentos inadequados e que no final das contas sai beneficiado. A lógica de construção do clown se opõe ao desenvolvimento psicológico do teatro realista, o clown age através de saltos emotivos, de atitudes imprevisíveis e exageradas. O palhaço pode sair do choro e chegar às gargalhadas sem problemas, sem que seja necessário um fio condutor subjetivo que conceda encadeamento à mudança de sentimento. Além disso, a comicidade do palhaço provoca o riso violento, por vezes desconcertante e crítico, tal como a ironia de Oswald de Andrade, que frustra expectativas criadas inicialmente pelo próprio texto. As brincadeiras são, ao mesmo tempo, ingênuas e agressivas. "Num ensaio sobre a essência do riso, Charles Baudelaire assinala que o caráter violento desta explosão é causado pelo grotesco, e que o cômico da pantomima está sem dúvida calcado na violência”. 56

\footnotetext{
${ }^{53}$ Idem, p.33.

${ }^{54}$ Rina Signer, obra citada, p.125/126.

${ }^{55}$ Maria Augusta Fonseca, obra citada, p.26.

${ }^{56}$ Maria Augusta Fonseca, obra citada, p.22.
} 
O protagonista de $O$ rei da vela surge, portanto, colocado entre a referência ao racionalismo, derivada da imagem do teólogo francês e a lógica antidramática e caricata, típica do circo, aludida através da figura de Abelardo Pinto, o Piolim.

\section{Evocação e destruição.}

Da mesma maneira que a figura de Abelardo aparece em tensão, já que preso a referências opostas que problematizam a sua identificação, também outras referências utilizadas na peça precisam ser reconhecidas como tal. Ou seja, as remissões a outros gêneros - seja o teatro de tese, a comédia de costumes ou as gagues de circo - aparecem aqui de maneira reflexiva, voltando-se sobre si mesmas, não se configurando somente por uma via, mas em via de mão dupla.

A mistura de gêneros, a ruptura com o princípio clássico das três unidades, a variedade de cenários e os diferentes efeitos cênicos juntam-se às cenas burlescas, num contexto surreal, absurdo. É essa linguagem de imagens cênicas que expressa uma verdade, mais eficaz que uma linha de pensamento discursiva e está no centro da construção da nova convenção dramática numa época de transição. Escrever com total liberdade de criação exige uma capacidade de montagem de imagens e de situações sem contrapartida, por expressar os esforços do homem moderno para se adaptar ao momento e apresentar esse mundo ao espectador. ${ }^{57}$

Como conseqüência da mistura de gêneros, as referências não podem ser lidas senão como um roteiro provisório, que a todo tempo precisa ser substituído. São referencias literárias que se problematizam e se desfazem a todo instante. Se insistirmos em um modelo de leitura estabelecido em bases dramáticas, sem brechas para o abandono do mesmo, o que poderia ser invenção na obra acaba se transformando em defeito ou inverossimilhança.

A obra que surge não se apresenta como novidade absoluta num espaço vazio, mas por intermédio de avisos, sinais visíveis e invisíveis, traços familiares ou indicações implícitas, predispõe seu público para recebê-la de uma maneira bastante definida. (...) O caso ideal para a

\footnotetext{
${ }^{57}$ Rina Signer, obra citada, p.81.
} 
objetivação de tais sistemas histórico-literários é o daquelas obras que, primeiramente, graças a uma convenção do gênero, do estilo ou da forma, evocam propositadamente um horizonte de expectativas em seus leitores para, depois, destruí-lo passo a passo. ${ }^{58}$

Graças à utilização de diversas convenções teatrais, presentes nas comédias de costumes, no teatro de tese, no teatro de revista, no circo e no melodrama, Oswald evoca o horizonte de expectativa de seus leitores/espectadores, para em seguida destruir passo a passo tais referências. Esse diálogo travado com outros gêneros e estilos, que se dá através da alusão e também da negação, aparece como procedimento básico e eficaz no decorrer da peça.

A forma do teatro de tese, assim como as demais referências observadas, aparece aqui como recurso estilístico deformado. A associação do teatro de Oswald de Andrade ao teatro de tese pode ser feita em via mão dupla, isto é, o teatro de tese está em tensão no teatro de Oswald, e não como forma estabelecida. A pista de investigação que se abre quando se incorpora a noção do teatro de tese torna-se mais eficaz quando pensamos no diálogo com e contra o proposto por esta forma teatral, reinante desde fins do século XIX.

O théâtre a thèse foi uma espécie de praga que o teatro burguês difundiu pelo mundo nos anos da segunda revolução industrial. Alastrou-se como ideal culto de comprometimento do autor nos debates da época, sem que a forma das peças almejasse igual reflexão crítica. A historiografia não costuma definir o gênero pela preocupação social e, sim, pela desconexão entre a fala e a situação dramática da cena, pelo predomínio da teorização abstrata sobre a relação entre as personagens, procedimento que se reforça pela presença de algum porta-voz do autor, um raisonneur (raciocinador) com funções ideologicamente mais dirigentes do que no teatro clássico. ${ }^{59}$

Ou seja, se fecharmos a compreensão de O rei da vela como uma peça comprometida com os preceitos do teatro de tese, como aponta Sábato Magaldi ${ }^{60}$, ou como uma "uma peça inspirada no drama conversação"61, como defende Iná Camargo Costa - o que significa em outras palavras a forma acabada do teatro de tese, que por sua vez está

\footnotetext{
${ }^{58}$ Hans Robert Jauss, A história da literatura como provocação à teoria literária. São Paulo, Ática, 1994, p.28.

${ }^{59}$ Sérgio Ricardo de Carvalho Santos, obra citada, p. 125.

${ }^{60}$ Sábato Magaldi, obra citada, 2004, p.109.

${ }^{61}$ Iná Camargo Costa, obra citada, 1996, p.151.
} 
associado à escola realista francesa, que, como vimos, no Brasil servia de modelo para a construção do teatro nacional nos moldes burgueses, defendido especialmente por autores como José de Alencar, desde meados do século XIX, e que tinha em Alexandre Dumas Filho exemplo máximo -, estamos vinculando o teatro de Oswald de Andrade a uma filiação por ele mesmo desmontada.

Oswald de Andrade coloca em cena alguns esquemas das relações sociais de um país marcado pelo signo da ambigüidade, que obedecia aos impulsos da modernização e buscava mudanças apenas aparentes para que tudo permanecesse igual. A fim de compor o retrato dessa sociedade, o autor apresenta tipos retirados da realidade e se dispõe a colocálos em discussão. Surge em cena o arranjo entre a aristocracia decadente, representada pela família de Heloísa, e o arrivista burguês, representado pela figura do agiota Abelardo I. Nesse jogo de interesses, a aceitação do agiota como membro da família faz parte das estratégias das velhas oligarquias para a manutenção das vantagens econômicas, enquanto para Abelardo indica o antigo desejo burguês de freqüentar as altas esferas da sociedade. Os ideais de transformação política que aparecem espalhados na trama - mesmo ditos às avessas através dos discursos cínicos de Abelardo I e II - se vêem esmagados pela engrenagem social brasileira, descomprometida com qualquer possibilidade de mudança efetiva.

Aquilo que poderia se transformar num discurso puramente temático/conversacional, onde um personagem central, porta voz do autor, uma espécie de raisonneur, expõe conteúdos aparentemente modernos, mas não desfaz a forma convencional e tenta convencer o espectador acerca de sua teoria, é logo desfeito. Através da desestruturação da ordem dramatúrgica, Oswald de Andrade constrói uma forma teatral repleta de interrupções críticas, afastando-se da fórmula da peça bem construída e abandonando o caminho do drama conversação. A técnica clássica do teatro de tese, que já tinha feito presença entre nós, com o endosso de Alencar, é, não somente abandonada, mas colocada em xeque.

A semelhança com o teatro de tese se vê retomada, por um lado, quando se tenta encontrar na figura de Abelardo I a função do raisonneur, aquele que no teatro de tese exercia a função de porta-voz do autor: “em Oswald esse papel é desempenhado fundamentalmente pelo novo rico, o agiota Abelardo I, que põe a nu as mazelas da sua 
classe e tem consciência do que o aguarda na história”. ${ }^{62}$ E, por outro, quando, seguindo esta opção de análise, O rei da vela é aproximado de peças como Deus lhe pague, de Joracy Camargo, apresentada com extremo sucesso no ano de 1932. As duas peças, quando comparadas, apresentariam como dado comum a presença do raisonneur dentro da trama, só que colocado na posição de protagonista, algo nem sempre comum ao tratamento conferido para esse personagem no teatro de tese. O que passa a ser visto como uma opção estilística de Oswald, que aqui tentaria - e falharia novamente - copiar as soluções formais de Joracy Camargo.

Neste ponto, Joracy Camargo e Oswald dão um passo adiante (ou para trás, não dispomos de material para decidir): promovem o personagem a protagonista de suas peças. Ainda aqui, é preciso distinguir com clareza, pois enquanto Deus lhe pague é um drama com final feliz e tudo (por isso é considerado comédia) $O$ rei da vela é uma farsa com desfecho dramático para o protagonista. $^{63}$

O raisonneur representa a moral ou o raciocínio adequado que realiza uma síntese ou uma reconciliação dos pontos de vista. No teatro brasileiro um bom exemplo é o personagem Meneses, o jornalista de As asas de um anjo, peça de José de Alencar. “Meneses, como definiu o próprio Alencar, é ‘a razão social encarnada em um homem'”, ${ }^{64}$

Em Deus lhe pague, o protagonista apresenta-se como um mendigo que aparenta uma velhice bem nutrida, possui barba e cabelos compridos, olhar sereno e expressões messiânicas. O personagem entra demonstrando saúde, porém ao avistar um passante, simula instantaneamente e com muita prática um grande abatimento. Senta-se diante de uma igreja, onde permanecerá durante toda a peça, com exceção dos momentos em que se colocará diante de um telão para que a narração se refira também ao passado. Assim, defronte da igreja, o Mendigo explica ao outro mendigo, de nome Barata, sua história, suas decepções e seu modo de vida atual.

O Mendigo justifica que optou por pedir dinheiro nas ruas depois que foi enganado pelo antigo patrão e teve que cumprir pena injustamente como assaltante. Resolveu então

\footnotetext{
${ }^{62}$ Sábato Magaldi, obra citada, 2004, p.109.

${ }^{63}$ Iná Camargo Costa, obra citada, p. 208

${ }^{64}$ João Roberto Faria, Dicionário do teatro brasileiro: temas, formas e conceitos. São Paulo, Perspectiva, 2006, p.266.
} 
parar de trabalhar honestamente e vingar-se da sociedade, adotando a profissão de mendigo. Para esclarecer sua estratégia de vingança o personagem, raciocinador da trama, expõe suas idéias: o mendigo é uma necessidade social, os homens precisam dele, "quem dá esmola pensa que está comprando a felicidade, e os mendigos, para eles, são os únicos vendedores desse bem supremo". ${ }^{65}$ Como vendedor de felicidade e contando com a necessidade de absolvição alheia, o Mendigo tornou-se, para espanto do companheiro, um milionário. Toda a teoria e o sucesso econômico alcançado por sua estratégia de vida são explicados ao outro mendigo sem espaços para discordâncias.

O diálogo aqui tem apenas a função de evitar o monólogo (ou, melhor, conferencia) do Mendigo. Se reunirmos as falas do Mendigo, teremos nada menos que uma seqüência de mal realizados paradoxos e tautologias. ${ }^{66}$

As intervenções do outro mendigo são como um estímulo para que o Mendigo desenvolva o próprio discurso. "Salta da peça, no cômputo final, um amontoado de frases feitas sobre a injustiça, a riqueza e a miséria". 67 Vê-se aqui um bom exemplo de peça de conversação, ou seja, exemplo de um "gênero que mostra figuras de aparência dramática debatendo sobre problemas com os quais não estão existencialmente comprometidas.”68 Aparentemente, a peça debate sobre o problema da miséria, porém o Mendigo, personagem principal, não possui nenhuma relação com o tema tratado. A sua história parece provir de um ponto de vista oposto, ele não é de fato um mendigo, ele se veste como tal, mas mora em uma mansão. E é somente ele, o mendigo-milionário que expõe suas idéias, o outro, que se chama Barata, não tem vez: “o mendigo pobre sequer possui um discurso próprio”. ${ }^{9}$

Depois de escutá-lo atenciosamente, Barata, que a princípio não entende como alguém pode ser “obrigado a fazer fortuna”70, mostra-se convencido. Outra personagem que aparece também enredada pelo discurso do Mendigo, com aparência de messias, é Nancy, a "mulher elegante" que vive ao seu lado, prisioneira não somente do seu dinheiro, como

\footnotetext{
${ }^{65}$ Joracy Camargo, Deus lhe pague. Rio de Janeiro, Edições Minerva, s/d, p. 22.

${ }^{66}$ Edwaldo Cafezeiro e Carmem Gadelha, História do teatro brasileiro. Rio de Janeiro, UFRJ / FUNARTE, 1996, p.446.

${ }^{67}$ Sábato Magaldi, Panorama do teatro brasileiro. São Paulo, Global, 1997, p.203.

${ }^{68}$ Sérgio Ricardo Santos de Carvalho, obra citada, p.125.

${ }^{69}$ Edwaldo Cafezeiro e Carmem Gadelha, obra citada, p.448.

${ }^{70}$ Joracy Camargo, obra citada, s/d, p.25.
} 
também de suas idéias. O que pode ser observado na seguinte fala do mendigo para sua companheira: "Se eu perguntar o que você sente por mim, você não responderá. Não é amor. Nem medo. É uma curiosidade inexplicável, que os outros chamariam de sugestão". 71 Por fim, Barata, o mendigo sem discurso, é quem reaproxima o Mendigo raisonneur de Nancy, que quase o abandonou ao saber de sua verdadeira "profissão".

Joracy Camargo não somente se vale do "teatro de idéias” para construir sua história, como também do "artificialismo fundamental do melodrama”, ${ }^{\text {, }}$ mas não de maneira a destruir tais expectativas, como o faz Oswald de Andrade; ao contrário, Camargo as confirma. A comparação entre as duas peças ajuda a compreender o quão distante do teatro de tese Oswald se colocava.

Enquanto o mendigo, personagem de Deus lhe pague, quer nos convencer da coerência de suas idéias - e é como se o fizesse, já que consegue convencer o outro mendigo e também a mulher com quem se reconcilia no final -, o personagem de $O$ rei da vela quer nos expor a sua incoerência. Abelardo I "é o protagonista e o vilão; o porta-voz do autor e o alvo de seus ataques, o burguês-capitalista ganancioso e o crítico desse mesmo capitalismo". ${ }^{73}$ Joracy Camargo trabalha a partir da concatenação de idéias para construir o seu mendigo, o personagem de Oswald é polifônico, não existe encadeamento definido para Abelardo I. Como protagonista sem caráter, como ser abúlico, o personagem oswaldiano, repentinamente, confessa sua inquietude:

Heloísa - você não vai ao banho? Estão todos prontos.

Abelardo I - Não vou! Estou com um pouco de dor de cabeça. Prefiro repousar. Leve esse Americano duma figa... Minha cara, eu estou vendo que peguei no duro, no batente, durante dez anos, para fazer uma porção de piratas jogarem ioiô!

Heloísa - Estás arrependido? Não te trago vantagens? Sociais? Físicas? Políticas... bancárias...

Abelardo - Mas é que às vezes, de repente perco a confiança. É como se o chão me faltasse. $^{74}$

\footnotetext{
${ }^{71}$ Idem, p. 138.

${ }^{72}$ Sábato Magaldi, obra citada, 1997, p.202.

${ }^{73}$ Rina Signer, obra citada, p.126.

${ }^{74}$ Oswald de Andrade, obra citada, 2003, p. 88.
} 
O personagem central da peça de Oswald de Andrade atravessa a narrativa transformando-se, mudando seu ponto de vista, seu posicionamento político, desfazendo qualquer coerência exigida de um raciocinador. Nessa incoerência transparente, nesse protagonista-clown sem encadeamento dramático, desnudado em seu cinismo, surge a negação de Oswald à referência inicialmente apontada. Se Abelardo I se assemelha a um raisonneur, é para em seguida desfazer tal referência, e, propositalmente, desmontá-la. A idéia de desenvolvimento de uma tese “filosófica, política ou moral, buscando convencer o público de sua legitimidade”75, se desfaz devido aos procedimentos formais da obra. Ao ser explicitamente tematizada, a tese vê-se também desnudada e o mesmo ocorre com a função de convencimento que lhe é própria.

Através das interferências textuais, dos ruídos entre obras, Oswald de Andrade, evoca propositadamente o marcado horizonte de expectativas presente na cena brasileira do início do século XX. Cada quebra de expectativa, cada relação formal primeiramente apontada e posteriormente desfeita, se apresenta como a destruição de um modo perceptivo conhecido e a proposição de novas possibilidades de leitura.

A arte simplesmente não pode se desenvolver sem estabelecer relações com formas anteriores. O que está em questão é apenas o nível, a consciência, o caráter explícito e o tipo específico dessa relação. ${ }^{76}$

O caráter explícito da relação apontada por Oswald de Andrade com formas anteriores, e ainda vigentes em seu tempo, é o da invenção. Ao sugerir outro modo de leitura, o autor procurava inventar outro modo de espectador. Para tal objetivo, Oswald destruía referências ainda aceitas como válidas na cena brasileira. A importância dessa destruição está na possibilidade de desautomatização dos modos perceptivos dos leitores/espectadores, ou, em outras palavras, o choque de expectativas proposto pela obra desfigurada, exige uma posição diferenciada do espectador diante da cena.

No terceiro ato, o procedimento de aproximação e negação de formas anteriores surge através de cena, à primeira vista melodramática, construída para encerrar a narrativa.

\footnotetext{
${ }^{75}$ Patrice Pavis, obra citada, 1999, p.385.

${ }^{76}$ Hans-Thies Lehmann, Teatro pós-dramático. São Paulo, Cosac Naify, 2007, p.34.
} 
Nesse caso, a sobreposição entre melodrama e outras linguagens se dá desde o diálogo inicial. Enquanto, numa atitude de mulher desesperada, prestes a perder o amante, "Heloísa se lastima prendendo com os braços as pernas de Abelardo I”, o protagonista, em tom completamente oposto, reitera o teor do relacionamento de ambos e assinala a incongruência da reação melodramática de sua futura esposa.

Heloísa - Que desgraça meu bem! Que pena! Que pena!

Abelardo I - Prefiro ser fraco... Heloisa. Você sabe por que nos íamos casar. Não era decerto para fazer um ménage de folhinha...

Heloísa - Que pena! Meu Deus!

Abelardo - Terás que procurar outro corretor. Você sabe... Nos casávamos para você pertencer mais à vontade ao Americano. Mas eu já não sirvo para essa operação imperialista. O teu corpo não vale nada nas mãos de um corretor arrebentado que irá para a cadeia amanhã... Ou será assassinado pelos depositantes. Essa falência imprevista vai me desmascarar.

Heloísa - Que horror! Eu não quero que você vá preso! ${ }^{77}$

No fim desse diálogo, Abelardo tira o revólver e anuncia o suicídio, Heloisa continua a reagir como em um melodrama - "Heloísa soluça fortíssimo” -, mas a cena de suicídio acaba sugerindo efeitos diversos. Com o revólver na mão, o protagonista pede se dirige ao público: "Fita em silencio os espectadores. Estão aí? Se quiserem assistir a uma agonia alinhada esperem! (grita) Vou atear fogo às vestes! Suicídio nacional!”. ${ }^{78}$

Como em todo melodrama, assim como também em toda comédia de costumes, tudo parece bem quando acaba em casamento e festa. Aqui, porém, em uma farsa absurda e com sabor trágico, o fim apresenta simultaneamente a morte e o casamento. Junto a um grito lancinante, ouve-se o tiro derradeiro, representado na encenação por uma salva de sete tiros de canhão. A cena reabre com Abelardo I desfalecido numa cadeira de rodas no meio da cena. Heloísa hesita um instante perto do morto, mas depois segura o braço de Abelardo II. Ouvem-se os acordes da marcha nupcial e surgem os personagens do segundo ato, todos

\footnotetext{
${ }^{77}$ Oswald de Andrade, obra citada, 2003, p.95.

${ }^{78}$ Idem, p.98.
} 
vestidos a rigor para a festa de casamento, sem prestar atenção ao cadáver com a cabeça tombada sobre a cadeira. O Americano é o último que aparece e o único que fala: “Oh! good business!". ${ }^{79}$ A oposição das imagens da morte e do casamento redireciona a fala do personagem. A justaposição de gêneros operada por Oswald coloca em tensão a narrativa e problematiza a leitura da cena.

\section{A recepção na mira de Oswald de Andrade.}

As interlocuções entre obras, que se tornam procedimento necessário para a leitura de $O$ rei da vela, não se dão de maneira a facilitar o jogo de linguagem proposto. Antes, as relações com formas anteriores intensificam o diálogo com o espectador. Oswald de Andrade constrói "um labirinto onde nem sempre a Ariana da poesia tem um fio preparado para nós". ${ }^{80}$ As diversas associações expostas no corpo do texto, como uma "imensa rede de significação"81, propõem a explicitação do ato artístico e, desta maneira, realizam um convite para que o espectador faça as próprias associações.

Essas produções do espectador oswaldiano podem ser também compreendidas a partir das reflexões de outro modernista. Em seu texto A escrava que não é Isaura, de 1925, o qual foi dedicado ao autor de O rei da vela, Mário de Andrade tratou de algumas mudanças na percepção e na construção do objeto artístico, a partir da modernidade, e destacou entre estas a simultaneidade e a polifonia.

Simultaneidade é a coexistência de coisas e fatos num momento dado.

Polifonia é a união artística simultânea de duas ou mais melodias cujos efeitos passageiros de embates de som concorrem para um efeito total final. (...)

Se cantarem a Canção do Aventureiro e Vem-cá-Bitú, dois cantores ao mesmo tempo, não temos artisticamente polifonia, mas cacofonia.

Há simultaneidade, mas realística, sem crítica, sem vontade de análise. (...)

Em todas as artes do tempo sem a soma total de atos sucessivos de memória (relativo cada um a cada sensação insulada) não poderia haver compreensão.

\footnotetext{
${ }^{79}$ Oswald de Andrade, obra citada, 2003, p. 109.

${ }^{80}$ Ruggero Jacobbi, obra citada, p.64.

${ }^{81}$ Carlos Gardin, obra citada, p.51.
} 
Mesmo um soneto passadista é a sensação complexa total final provinda dessa soma, que determina o valor emotivo da obra.

Uma diferença: num soneto passadista dá-se concatenação de idéias: melodia.

Num poema modernista dá-se superposição de idéias: polifonia. ${ }^{82}$

A superposição de idéias que constitui o texto de Oswald de Andrade convida o espectador a realizar ato semelhante diante da cena teatral. O modo como a peça foi estruturada resulta na quebra das normas teatrais tradicionais e resulta em convite insistente para que o espectador não espere somente um divertimento culinário, mas se coloque diante da obra de maneira ativa, com a percepção crítica acordada. Oswald, assim como outros modernistas, tentava "forçar as portas da cidadela conservadora em que se convertera o palco brasileiro" ${ }^{83} \mathrm{O}$ passo mais importante que sua dramaturgia dava estava relacionado à transformação desse diálogo entre a cena e os espectadores, à ruptura da percepção automatizada. O teatro para Oswald era um campo de batalha, uma luta travada contra a lógica estabelecida de espetáculos complacentes, o que, por contraposição, marcava muitas vezes o tom agressivo de suas opções dramatúrgicas.

Na obra teatral de Oswald o debate sobre o fazer artístico se torna explícito. A digressão acerca dos procedimentos estéticos adotados, iniciada em o Rei da vela e reiterada em textos posteriores, como em A Morta, se estabelece como uma discussão que ainda hoje nos diz respeito. O processo de criação de Oswald de Andrade pode ser, se colocado em tensão com presente o histórico, analisado em diálogo com as experimentações cênicas recentes: ao mesmo tempo em que assume o espectador como interlocutor primordial, a cena contemporânea propõe uma nova disponibilidade perceptiva e outro modo participativo aos espectadores, tomado como atuantes.

A quebra de convenções lingüísticas apresentadas em $O$ rei da vela, a desestruturação da carpintaria dramática, do desfecho bem preparado, assim como os discursos líricos e épicos que invadem a cena, estabelecem um modo de relação inusitado com os espectadores, nem sempre compreensível de antemão. Esse teatro repleto de pedaços de outras obras, por vezes dissonantes, expõe "através desse hibridismo crítico,

\footnotetext{
${ }^{82}$ Mário de Andrade, Obra imatura: há uma gota de sangue em cada poema; primeiro andar; a escrava que não é Isaura. São Paulo, Editora Itatiaia, 1980, p.269.

${ }^{83}$ Décio de Almeida Prado, O teatro brasileiro moderno. São Paulo, Perspectiva, 2003, p.27.
} 
disso que poderia se chamar uma "técnica de citações" estrutural, a vocação mais profunda da empresa oswaldiana”. ${ }^{84}$

${ }^{84}$ Haroldo de Campos, obra citada, 2007, p.19. 


\section{Consideracões finais}

É comum a historiografia definir a aparição do modernismo teatral no cenário brasileiro na década de 1940, a partir do teatro de Nelson Rodrigues, fato que nos distancia de experiências cênicas genuinamente modernas ocorridas no calor das duas décadas anteriores. Além disso, determinar o modernismo teatral brasileiro a partir de suas encenações, longas temporadas e larga afluência de público, ou seja, a partir da montagem de Vestido de noiva, com direção de Ziembinski, com o grupo Comediantes, em 1943, implica em “empurrar” as propostas cênicas de Oswald de Andrade, por exemplo - as quais só poderiam ser reconhecidas depois da conhecida encenação em 1967, pelo Teatro Oficina -, para depois do teatro de Nelson Rodrigues, fazendo-as coincidir em tempo histórico com os espetáculos do TBC e o repertório do Arena. Enquanto que o diálogo estético e histórico travado pelo teatro de Oswald inicia-se lá atrás, desde o estabelecido na década de 1930, em oposição às opções estéticas vigentes naquele momento.

O que pretendemos sublinhar é que a não encenação do teatro de Oswald de Andrade - e aqui estamos falando de toda a sua produção a partir da década de 1930, O rei da vela, $O$ homem e o cavalo, A morta e, inclusive, $O$ santeiro do mangue, que possuiu várias versões entre 1936 e 1950, já sem a esperança por parte do autor de conseguir encená-la - é parte significativa do processo histórico que envolveu a efetivação do modernismo no teatro em nosso país. A recusa com que foi recebido o seu teatro pelos seus contemporâneos é a primeira concretização de sua obra pioneira. As suas peças - prenhes de propostas modernas na própria constituição dramatúrgica, nas rubricas e no imaginário cênico proposto ao leitor-espectador -, com exceção de $O$ santeiro do mangue, foram publicadas na ocasião em que foram escritas e, portanto, lidas, mesmo que por um círculo restrito de leitores. A não encenação dessas peças, no momento de sua produção, talvez possa nos ajudar a compreender, mais do que qualquer outro texto encenado com sucesso no mesmo período, as principais características do teatro brasileiro nas primeiras décadas do século XX: um teatro marcado pelo veto, que se mostrava obediente aos modelos de 
uma carpintaria dramática eficiente, dominante desde o século XIX, e contrário aos desafios propostos por experiências de vanguarda.

A recusa ao teatro de Oswald está diretamente ligada ao rompimento que aparece de maneira nítida em sua obra com as expectativas de seu público contemporâneo, isto é, a não encenação corresponde justamente ao enfrentamento, típico da modernidade, proposto pelo autor diante das normas vigentes de produção artística. Ao romper com expectativas vigentes, a obra recusada - o teatro de Oswald, assim como as experiências de Flávio de Carvalho -, abre a possibilidade de compreensão tanto do horizonte de expectativa do período, que foi desafiado, quanto do efeito provocativo de seus trabalhos.

A maneira pela qual uma obra literária, no momento histórico de sua aparição, atende, supera, decepciona ou contraria as expectativas de seu público inicial oferece-nos claramente um critério para determinação de seu valor estético. ${ }^{1}$

A contrariedade diante de experiências artísticas que não se mostram facilmente assimiláveis, a mudança de horizonte exigida pelo esforço de compreensão diante de uma obra nova atesta o seu valor estético. E, no nosso caso, atesta a modernidade efetiva desses autores recusados. “À medida que a ruptura com a percepção automatizada se tornou um critério estético essencial na modernidade”2, não se pode esperar que uma obra que se compõe através de procedimentos artísticos modernos agrade facilmente. De modo que se precisa definir a instauração do moderno entre nós no momento de sua aparição, de sua realização a contragosto, e não necessariamente no momento em que foi aceito pelo público.

Uma proposta artística que desobedece a fórmulas prontas e rompe com muitas convenções é, na maioria das vezes, compreendida pouco a pouco. As cenas desafiadoras do modo de produção teatral que viemos tratando até aqui mostravam-se rejeitadas e também desprendidas de fórmulas prontas, atestando assim o enfrentamento estético dessas empreitadas. Seria possível imaginar $O$ rei da vela encenado sob aplausos do público, o mesmo que se entusiasmou diante de Deus lhe pague, grande sucesso do ano de 1932 ?

\footnotetext{
${ }^{1}$ Hans Robert Jauss, A história da literatura como provocação à teoria literária. São Paulo, Ática, 1994, p.31.

${ }^{2}$ Hans-Thies Lehmann, Teatro pós-dramático, São Paulo, Cosac Naify, 2007, p. 293.
} 
Além disso, a censura ao modernismo no teatro brasileiro não se configurou somente com a não encenação de Oswald de Andrade. Sucessivos vetos ao embate moderno no âmbito da cena artística foram notados. Desde o início do século XX, quando tivemos as nossas primeiras discussões acerca do teatro moderno, estimuladas pela visita da companhia de André Antoine ao país, e foram discutidas questões de repertório, encenação e atuação, ficava claro, através dos comentários de escritores e jornalistas, que por aqui se podia até admitir uma atuação naturalista, contanto que os textos não contrariassem a premissa de divertir a platéia mostrando-se por demais sérios e contundentes.

Quando autores como Benjamin Lima e Renato Vianna ensaiaram construir histórias com desfechos ou modos de produção atípicos, convidando o espectador para uma recepção crítica diversa, ficava patente a aclimatação do ideário moderno entre nós. Diante das experiências cênicas de Flávio de Carvalho, a distância de teor artístico entre o estabelecido na cena e as suas propostas tornava-se evidente. Isso para ficarmos no âmbito do teatro, pois nada mais enfático para o atraso de reconhecimento da arte moderna entre nós do que os comentários recebidos por Anita Malfatti na ocasião de sua primeira exposição no ano de 1917. A crítica, publicada no jornal Estado de S. Paulo pelo escritor Monteiro Lobato com o título “A propósito da Exposição Malfatti”, dá a medida do problema que significava propor, no nosso caso, um teatro que rompesse com os cânones vigentes:

Há duas espécies de artistas. Uma composta dos que vêem normalmente as coisas e em conseqüência disso fazem arte pura, guardando os eternos ritmos da vida, e adotados para a concretização das emoções estéticas, os processos clássicos dos grandes mestres. (...) A outra espécie é formada pelos que vêem anormalmente a natureza, e interpretam-na à luz de teorias efêmeras, sob a sugestão estrábica de escolas rebeldes, surgidas cá e lá como furúnculos da cultura excessiva. São produtos do cansaço e do sadismo de todos os períodos de decadência: são frutos de fim de estação, bichados ao nascedouro. (...) Embora eles se dêem como novos, precursores de uma arte a vir, nada é mais velho que uma arte anormal ou teratológica: nasceu com a paranóia e com a mistificação. ${ }^{3}$

\footnotetext{
${ }^{3}$ Monteiro Lobato, “A propósito da Exposição Malfatti”. O Estado de S. Paulo, 20/12/1917. In: Mário da Silva Brito, História do modernismo brasileiro. Rio de Janeiro, Civilização Brasileira, 1964, p.52.
} 
Era contra essa visão conservadora e avessa a qualquer possibilidade de transformação (ou deformação) da arte, visível na crítica de Monteiro Lobato, que os autores modernistas se batiam. Não por acaso, Flávio de Carvalho, em artigo no Diário de São Paulo, anunciava que "A única arte que presta é a arte anormal”. ${ }^{4}$ O teatro de Oswald apresentava personagens deformados e invertidos, exagerados e contraditórios. Tanto a pintura de Malfatti, quanto as experiências cênicas de Flávio e de Oswald apresentavam um “isto problemático e reflexivo, que é necessário interrogar e decifrar”. 5 Em texto incluído no livro Obra Imatura, Mário de Andrade, deixando evidente que tanto a produção artística quanto a teórica do período demonstravam ter ciência do embate estético em jogo, se referiu ao espanto do espectador diante da arte moderna:

O poeta não fotografa: cria. Ainda mais: não reproduz: exagera, deforma, porém sintetizando. E da escolha dos valores faz nascer euritmias, relações que estavam esparsas na vida, na natureza, e que a ele, poeta, competia descobrir e aproximar. Nisto consiste seu papel de artista. O poeta parte de um todo de que teve a sensação, dissocia-o pela análise e escolhe os elementos com que erigirá um outro todo, não direi mais homogêneo, não direi mais perfeito que o da natureza mas

\section{DUMA OUTRA PERFEIÇÃO \\ DUMA OUTRA HOMOGENEIDADE}

\section{(...)}

A incompreensão com que os modernistas de todas as artes são recebidos provém em parte disso. O espectador procura na obra de arte a natureza e como não a encontra, conclui: - Paranóia ou mistificação! O autor é idiota. Il y a toujours l'alternative : "C'est idiot et je suis idiot". ${ }^{6}$

A arte moderna não oferece mais um suposto duplo da realidade aparente, ao contrário, a obra de arte a partir de então se empenha em dissolver e questionar o visível, denunciando assim a sua fragilidade. Outra questão cara à arte moderna, e diretamente relacionada com seu novo posicionamento, é a efetiva participação do espectador. Já que

\footnotetext{
${ }^{4}$ Flávio de Carvalho, “A única arte que presta é a arte anormal”. Diário de São Paulo, São Paulo, 20/06/1936. In: Mattar, obra citada, p.71.

${ }^{5}$ Ronaldo Brito. Experiência crítica - textos selecionados: Ronaldo Brito. Organização: Sueli de Lima. São Paulo, Cosac e Naify, 2005, p.75.

${ }^{6}$ Mário de Andrade, Obra imatura: Há uma gota de sangue em cada poema; primeiro andar; a escrava que não é Isaura. São Paulo, Ed.Itatiaia, 1980, p.238.
} 
não se trata mais de imitação, importa também construir um olhar capaz de desvendar a obra e suas sugestivas associações. Ou seja, a arte moderna aponta o seu foco para o âmbito da recepção, afirmando não somente que a efetivação da obra se dá a partir do encontro com o espectador, mas também o quanto a obra precisa desafiar esse mesmo espectador para que este possa, ao se deparar com aspectos desconhecidos, ao ter as suas expectativas frustradas, estabelecer uma relação de produtividade com a mesma. Ou seja, não se trata somente de reconhecer o trabalho autoral do espectador, mas propõe-se que a obra intensifique ou dê conta de tal diálogo.

\section{Veto refeito.}

O veto ajustado ao modernismo se desfaz quando retomamos as propostas artísticas do período, retomamos o diálogo contido numa obra do passado e deixamos que ele ressoe novamente, quando olhamos mais uma vez para o passado e compreendemos a história não como algo acabado e sem modificações possíveis, mas como um processo repleto de experiências sempre possíveis de serem efetivadas. A história das obras artísticas se constitui, assim, como processo de recepção e produção que se realiza na atualização das obras por parte do leitor, que as recebe, do autor, que se faz novamente produtor, e da crítica, que sobre elas reflete. Porém, o veto se vê de novo configurado quando nos relacionamos com essas experiências sem deixar que novas leituras possibilitem o acesso à sua forma transgressora.

Diante de recente montagem, em 1992, de A morta, de Oswald de Andrade, no Rio de Janeiro, pela Cia dos atores, a crítica Bárbara Heliodora escreveu artigo para o jornal $O$ Globo intitulado "Um Oswald que não deve ser ressuscitado”, no qual desautoriza a aptidão dramatúrgica do autor, e justifica seu ponto de vista ao afirmar a falta de compreensão por parte de Oswald da essência da forma dramática:

Voltamos ao eterno lugar-comum: talento para a forma dramática é uma coisa altamente específica, e apesar de sua inteligência e de seu brilhantismo, Oswald de Andrade pura e simplesmente não foi aquinhoado com ele: o autor ignora a essência da forma dramática - a da transmissão de um conteúdo por meio de uma ação transformadora; como muita gente boa, ele cai 
no triste engano de pensar que distribuir falas por vários "personagens” significa escrever teatro. (...)

Em A morta não há ação mas, tão somente, três momentos perfeitamente iguais entre personagens arbitrários cujas posições não se alteram. Não chegando a lugar algum, o debate é tautológico. E esse é o grande fato determinante para a derrota dos imensos esforços do diretor Enrique Diaz e os 13 integrantes da Cia dos atores, que obviamente gastaram muito tempo tentando elaborar um espetáculo que pudesse chegar a dourar a insuportável pílula o bastante ao menos para torná-la cenicamente digerível: quando um texto é injustificável quanto o de $A$ morta ele não permite qualquer criatividade orgânica, que ilumine alguma proposta nele contida. O resultado, no caso, fracassa entre outras coisas porque tudo é necessariamente aleatório, arbitrário e conseqüentemente repleto de gratuidades, de esforços inúteis e vazios de significado. ${ }^{7}$

Depois de um século inteiro marcado pela crise da forma dramática, quando não pela recusa veemente a esta forma artística, a reflexão crítica causa espanto, pois clama pelo superado, e mais, o toma como padrão incontornável de análise. Como se relacionar com tal exame, que sustenta critérios dramáticos diante de um texto como A morta, em que podemos observar que é “a própria forma dramática que está sendo incendiada”, em que a organização das cenas se faz em quadros autônomos e a atribuição de sentidos para as mesmas precisa ser efetivada pelo espectador? Seria como esperar o prazer estético diante de regras conhecidas de antemão, em que o autor responde com uma cena tal qual esperada pelo espectador, diante de uma peça que se propõe justamente a discutir o esquema dramático, a relação entre artista, obra e público. Oswald em todo o seu teatro nega expectativas referentes a uma forma dramática bem-feita, pronta a ser consumida e, nessa peça, publicada juntamente com $O$ rei da vela, vai além, desafiando o receptor a produzir sentido para cada imagem apresentada, para cada fragmento ou arremedo de personagem. $\mathrm{O}$ teatro de Oswald dialogava com expectativas dramáticas de seu tempo, mas são essas mesmas expectativas que, de alguma maneira, por mais incrível que possa parecer, ressurgem e parecem perdurar nos dias de hoje por aqui, tornando-o um autor ainda

\footnotetext{
${ }^{7}$ Bárbara Heliodora, apud Enrique Diaz, Marcelo Olinto e Fábio Cordeiro (orgs.). Na companhia dos atores. Rio de Janeiro, Aeroplano, 2006, p.311.

${ }^{8}$ Luiz Fernando Ramos, “O teatro de Oswald e a feliz confusão do lírico com o dramático: entre o épico e a chanchada, a precoce modernidade tardia”. Palestra realizada no Sesc Pinheiros, 2005.
} 
“insuportável”. Seria esta uma manifestação explícita de perpetuação do veto ao modernismo em nosso teatro?

\section{A tensão entre o passado e o presente.}

O contexto histórico da leitura de uma obra é ressaltado através da continuidade de recepções, ou seja, as diversas recepções ocorridas ao longo da história para uma mesma obra enriquecem o sentido original, possibilitando que aspectos não percebidos na época de sua feitura brotem posteriormente; ou, podemos dizer, ao contrário, são essas recepções efetivadas ao longo da história que criam condições para que a incompreensão permaneça. Assim, “o sentido da obra de arte não deve ser entendido mais como substância atemporal, e sim como totalidade que se constrói historicamente".9

A recepção da obra, quando se apresenta distante do comumente conhecido, “deixase objetivar historicamente no espectro das reações do público e do juízo da crítica sucesso espontâneo, rejeição ou choque, casos isolados de aprovação, compreensão gradual ou tardia”. ${ }^{10}$ A obra é o resultado da convergência do texto e de sua recepção, e sua análise se enriquece ao ser captada em suas concretizações históricas sucessivas. O efeito estético e a recepção encontram-se, portanto, vinculados não somente ao passado, mas também ao presente. O historiador quando lê uma obra do passado, refaz a sua recepção e refaz a obra.

O historiador, como define Walter Benjamim ${ }^{11}$, precisa partir das tensões do presente e se reportar ao passado para encontrar sonhos que se relacionem com os de seu tempo, e que foram sufocados, para liberar a potência revolucionária dos atos e deixar que invadam e transformem o presente e o futuro. A tarefa do historiador é a de impedir que a história se repita indefinidamente, como reproduções de um sempre-igual que se apresenta disfarçadamente com aspecto de novidade. O filósofo propõe que o continuum do tempo seja paralisado para que, como num salto de tigre, possamos nos lançar ao passado sem perder de vista os dados constituintes do presente. Cabe ao historiador não apenas narrar o que aconteceu, mas encontrar nesse passado os germes de uma outra história, uma história

\footnotetext{
${ }^{9}$ Hans Robert Jauss, apud Regina Zilberman. Estética da recepção e história da literatura. São Paulo, Ática, 1989, p.65.

${ }^{10}$ Hans Robert Jauss, obra citada, 1994, p.31.

${ }^{11}$ Walter Benjamin, Obras escolhidas: Magia e Técnica, Arte e Política. São Paulo, Brasiliense, 1993.
} 
não oficial. Esta leitura a contrapelo dos fatos históricos, proposta por Benjamin, aponta para a identificação dos lampejos de um passado incerto que reflete sobre o presente. Lampejos que, como tensões históricas encontradas no passado, precisam ser revelados e revigorados para que ressoem no presente.

O nosso modernismo se configura como uma espécie de lampejo no passado, efetivando-se nas entrelinhas da cena, sem respaldo da crítica e sem sucesso de público. As propostas modernas dos anos 1920 e 1930, que efetivaram uma guinada em rumo a uma experiência desconhecida, desautomatizadoras de hábitos perceptivos, foram mal recebidas, não encenadas, criticadas, mantendo-se desse modo à margem da historiografia da cena brasileira. Reler estes autores e retomar seus desejos de embate significa deixar que os ventos modernistas ali presentes soprem de novo, balancem, a partir do interesse do presente, as vigas do convencionalismo da época, que ainda podem ser vistas nos dias de hoje. Assim como na cena teatral contemporânea, nem tudo era conservador no teatro brasileiro do passado. O teatro no Brasil possui uma trajetória de revoltas sufocadas e não de inexistência de revoltas. Os lances modernos das primeiras décadas do século XX, em pleno embate, precisam ser de novo percebidos, em diálogo com o modo próprio com que se constituíram, e sem roteiros prévios de análise. 


\section{Bibliografia}

AGUIAR, Flávio. A comédia nacional no teatro de José de Alencar. São Paulo, Ática, 1984.

ALENCAR, José de. Ao correr da pena. São Paulo, Melhoramentos, s/d.

ANDRADE, Mário de. Obra imatura: há uma gota de sangue em cada poema; primeiro andar; a escrava que não é Isaura. São Paulo, Editora Itatiaia, 1980.

ANDRADE, Oswald de. A utopia antropofágica. São Paulo, Globo, 1995.

A morta e O homem e o cavalo. São Paulo, Globo, 2005.

O rei da vela. São Paulo, Globo, 2003.

. Obras Completas VII: poesias reunidas. Rio de Janeiro, Civilização Brasileira, 1971.

. Obras completas VIII, teatro: A morta, O rei da vela, O homem e o cavalo. Rio de Janeiro, Civilização Brasileira, 1976.

. Ponta de Lança. São Paulo, Globo, 1991.

. Serafim Ponte Grande, São Paulo, Globo, 2007.

. Telefonema. Introdução e estabelecimento do texto de Vera Chalmers. Rio de

Janeiro, Civilização Brasileira, 1976.

. Memórias sentimentais de João Miramar. São Paulo, Globo, 2004.

e ALMEIDA, Guilherme. Obras completas: Mon coeur balance, Leur âme. São

Paulo, Globo, 1991.

ANTOINE, André. Conversas sobre a encenação. Tradução de Walter Lima Torres. Rio de Janeiro, 7Letras, 2001.

AREAS, Vilma. Martins Pena: Comédia. São Paulo, Martins Fontes, 2007. 
ÀVILA, Affonso (org.). O modernismo. São Paulo, Perspectiva, 1975.

BABLET, Denis e JACQUOT, Jean (orgs.). Le lieu théatral dans la société moderne. Paris, CNRS, 1996.

BARTHES, Roland. Escritos sobre teatro. São Paulo, Martins Fontes, 2007.

BAUDELAIRE, Charles. As flores do mal. São Paulo, Editora Max Limonad ltda., 1985. . Le spleen de Paris. Paris, Brodard et Taupin, 1972.

BENJAMIN, Walter. Obras escolhidas: magia e técnica, arte e política. São Paulo, Brasiliense, 1993.

BENTLEY, Eric. O dramaturgo como pensador. Rio de Janeiro, Editora Civilização Brasileira, 1991.

BERMAN, Marshall. Tudo que é sólido desmancha no ar: a aventura da modernidade. São Paulo, Companhia das Letras, 1986.

BRANDÃO, Tânia. A máquina de repetir e a fábrica de estrelas: teatro dos sete. Rio de Janeiro, 7Letras, 2002.

BRECHT, Bertolt. Estudos sobre teatro. Rio de Janeiro, Nova Fronteira, 1978.

BRITO, Ronaldo. Experiência crítica - textos selecionados: Ronaldo Brito. Organização: Sueli de Lima. São Paulo, Cosac e Naify, 2005. . “O moderno e o contemporâneo”. In: Experiência crítica. Caderno de textos 1. Rio de Janeiro, FUNARTE, 1980.

BURKE, Peter (org.). A escrita da história. São Paulo, UNESP, 1992.

CAFEZEIRO, Edwaldo e GADELHA, Carmem. História do teatro brasileiro. Rio de Janeiro, UFRJ / FUNARTE, 1996. 
CALVINO, Italo. Se um viajante numa noite de inverno. São Paulo, Companhia das Letras, 1999.

CAMARGO, Joracy. Deus lhe pague. Rio de Janeiro, Edições Minerva, s/d

CAMPOS, Haroldo de. Deus e o diabo no Fausto de Goethe. São Paulo, Perspectiva, 2005.

. "Serafim: um grande não livro”. In: ANDRADE, Oswald de. Serafim Ponte

Grande. São Paulo, Globo, 2007.

CANCLINI, Nestor Garcia. A socialização da arte. São Paulo, Editora Cultrix, 1984.

CARLSON, Marvin. Teoria do Teatro. São Paulo, Unesp, 1997

CARVALHO, Flávio de. Experiência $n^{\circ}$ 2: realizada sobre uma procissão de Corpus Christi: uma possível teoria e uma experiência. Rio de Janeiro, NAU, 2001.

Origem animal de deus e O bailado do deus morto. São Paulo, Difusão Européia do Livro, 1973.

CARVALHO, José Murilo de. Os bestializados. São Paulo, Companhia das letras, 2006.

COSTA, Iná Camargo. A hora do teatro épico no Brasil, São Paulo, Paz e Terra, 1996. . Sinta o drama. Petrópolis, Vozes, 1998.

COSTA, Maria Cristina Castilho. Censura em cena: teatro e censura no Brasil: arquivo Miroel Silveira. São Paulo, EDUSP / Fapesp / Imprensa Oficial do Estado de São Paulo, 2006.

CURY, José João. O teatro de Oswald de Andrade: ideologia, intertextualidade e escritura. São Paulo, Annablume, 2003.

DELEUZE, Gilles. Nietzsche. Lisboa, Edições 70, 2007.

DESCOTES, Maurice. Le public de théâtre et son histoire. Paris, Presses Universitaires,1964. 
DIAZ, Enrique; OLINTO, Marcelo; CORDEIRO, Fábio (orgs.). Na companhia dos atores. Rio de Janeiro, Aeroplano, 2006.

DICIONÁRIO DO TEATRO BRASILEIRO. J. Guinsburg, João Roberto Faria, Mariângela Alves de Lima (orgs.), São Paulo, Perspectiva, 2006.

DÓRIA, Gustavo. Moderno teatro brasileiro. Rio de Janeiro, SNT, 1975.

DUVIGNAUD, Jean. Sociologia do comediante. Rio de Janeiro, Zahar Editores, 1972.

FARIA, João Roberto. Idéias teatrais: o século XIX no Brasil. São Paulo, Perspectiva, 2001.

O teatro realista no Brasil: 1855-1865. São Paulo, Perspectiva, 1993.

Teatro na estante. São Paulo, Atelier Editorial, 1998.

FERREIRA, Adriano de Assis. Teatro Trianon: forças da ordem x forças da desordem.

São Paulo, Dissertação de mestrado. Departamento de Teoria Literária e Literatura Comparada, Universidade de São Paulo, 2004.

FERREIRA, Procópio. Procópio Ferreira apresenta Procópio: um depoimento para a história do teatro no Brasil. Rio de Janeiro, Rocco, 2000.

FLAUBERT, Gustave. Madame Bovary. Círculo do Livro Ltda., 1994.

FONSECA, Maria Augusta. Oswald de Andrade, 1890-1954: biografia. São Paulo, Art Editora, Secretaria do Estado da Cultura, 1990. . Palhaço da burguesia: Serafim Ponte Grande, de Oswald de Andrade e suas relações com o universo do circo. São Paulo, Editora Polis, 1979.

FRAGA, Eudinyr. O simbolismo no teatro brasileiro. São Paulo, Art e Tec Editora, 1992.

GAGNEBIN, Jeanne Marie. História e narração em Walter Benjamin. São Paulo, Perspectiva, 1994. 
. Sete aulas sobre linguagem, memória e história. Rio de Janeiro, Imago, 1997.

“ "Walter Benjamin: memória, história e narrativa”. In: Mente, Cérebro e Filosofia.

São Paulo, Duetto, nº 7, 2008.

GARDIN, Carlos. O teatro antropofágico de Oswald de Andrade: da ação teatral ao teatro de ação. São Paulo, Annablume, 1995.

GASSNER, John. Mestres do teatro I. São Paulo, Perspectiva, 1974. . Mestres do teatro II. São Paulo, Perspectiva, 1991.

GOETHE, Johann Wolfgang. Fausto. Belo Horizonte, Editora Itatiaia, 1987.

GONZAGA, Armando. Comédias. São Paulo, Livraria Teixeira, 1940.

IBSEN, Henrik. Casa de bonecas. Lisboa, Guimarães e Cia Editores, 1916.

INNERARITY, Daniel. “La experiencia estética según Jauss”. In: Hans Robert Jauss. Pequena apologia de la experiência estética. Barcelona, Ediciones Paidós Ibérica, 2002.

ISER, Wolfgang. O ato da leitura, vol. 1. São Paulo, Editora 34, 1996.

JACOBBI, Ruggero. O espectador apaixonado. Porto Alegre: Curso de Arte Dramática da Faculdade de Filosofia, URGS, s/d.

JAUSS, Hans Robert. A história da literatura como provocação à teoria literária. São Paulo, Ática, 1994. . “O texto poético na mudança de horizonte de leitura”. In: LIMA, Luiz Costa.

Teoria da literatura em suas fontes. Rio de Janeiro, Francisco Alves, 1983.

. Pour une herméneutique littéraire. Paris, Gallimard, 1982.

Por une esthétique de la réception. Paris, Gallimard, 1978. 
Pequena apologia de la experiência estética. Barcelona, Ediciones Paidós Ibérica, 2002.

JÚNIOR, Sangirardi. Flávio de Carvalho: o revolucionário romântico. Rio de Janeiro, Philobiblion, 1985.

KONDER, Leandro. Walter Benjamin. O Marxismo da Melancolia. Rio de Janeiro, Ed. Campus, 1989.

LAHUERTA, Milton. “Os intelectuais e os anos 20: moderno, modernista, modernização”. In: DE LORENZO, Helena Carvalho e COSTA, Wilma Peres da (orgs.). A década de 1920 e as origens do Brasil moderno. São Paulo, UNESP, 1997.

LARA, Cecília de. Antonio Alcântara Machado: experimentação modernista em prosa. Tese de Livre Docência, Faculdade de Filosofia, Letras e Ciências Humanas da Universidade de São Paulo, 1981.

LEHMANN, Hans-Thies Lehmann. Le théâtre postdramatique. Paris, L’Arche, 2002. Teatro pós-dramático. São Paulo, Cosac Naify, 2007.

LEITE, Luiza Barreto. In: Depoimentos II, Rio de Janeiro, MEC/SNT, 1977.

LEITE, Rui Moreira. Flávio de Carvalho: entre a experiência e a experimentação. Tese de doutorado, Departamento de Artes Plásticas da Escola de Comunicações e Artes da Universidade de São Paulo, 1994.

LIMA, Benjamim. Teatro: o homem que marcha; o homem que ri; o martírio de Don Juan. Rio de Janeiro, Editora Aurora, s/d.

LIMA, Luiz Costa (org.). A literatura e o leitor. Rio de Janeiro, Forense Universitária, 1989. 
. O controle do imaginário: razão e imaginação nos tempos modernos. Rio de Janeiro, Forense Universitária, 1989.

. O fingidor e o censor: no ancien régime, no iluminismo e hoje. Rio de Janeiro, Forense-Universitária, 1988.

. Mímesis e modernidade. São Paulo, Editora Paz e Terra, 2003.

. Teoria da literatura em suas fontes. Rio de Janeiro, Francisco Alves Editora, 1983.

LOPES, Ângela Leite. Nelson Rodrigues: trágico, então moderno. Rio de Janeiro, Nova Fronteira, 2007.

MACHADO, António de Alcântara. Pathé Baby. Rio de Janeiro, Livraria Garnier, 2002. Novelas paulistanas: Brás, Bexiga e Barra Funda; laranja da China e outros contos. São Paulo, Editora Ática, 2003.

MAGALDI, Sábato. Moderna dramaturgia brasileira. São Paulo, Perspectiva, 1998. . Panorama do teatro brasileiro. São Paulo, Global, 1997. . O teatro de Oswald de Andrade. Tese de doutoramento em Literatura Brasileira. Faculdade de Filosofia, Letras e Ciências Humanas da Universidade de São Paulo, 1972. . Teatro da ruptura: Oswald de Andrade. São Paulo, Global, 2004. . O texto no teatro. São Paulo, Perspectiva/EDUSP, 1989. e VARGAS, Maria Thereza. Cem anos de teatro em São Paulo: 1875 a 1974. São Paulo, Editora Senac, 2001.

MAGALHÃES JR. R. As mil e uma vidas de Leopoldo Fróes. Rio de Janeiro, LISA Livros Irradiantes S.A., 1971. 
MALUF, Marina \& MOTT, Maria Lúcia. Recônditos do mundo feminino. In: SEVCENKO, Nicolau (org.). História da vida privada no Brasil, vol. 3. São Paulo, Companhia das Letras, 1998.

MANGUEL, Alberto. Uma história da leitura. São Paulo, Companhia das Letras, 1997.

MASSA. Clóvis. "Estética teatral e teoria da recepção". In: Concurso nacional de monografias: prêmio Gerd Bornheim: teatro no Brasil, teatro no Rio Grande do Sul. Porto Alegre, Editora da Cidade, 2007.

MATTAR, Denise. Flávio de Carvalho: 100 anos de um revolucionário romântico. Rio de Janeiro, CCBB, 1999.

MENCARELLI, Fernando Antonio. Cena aberta. Campinas, Editora da Unicamp, 1999.

MILLARÉ, Sebastião. A batalha da quimera: estudo sobre o teatro de Renato Vianna. São Paulo, obra ainda inédita, 2001.

MORAIS, Antonio Carlos Robert de. Flávio de Carvalho. São Paulo, Brasiliense, 1984.

MOSTAÇO, Edélcio. Moderno (Teatro) - verbete. In: Dicionário do teatro brasileiro: temas, formas e conceitos. GUINSBURG, J.; FARIA, João Roberto; LIMA, Mariângela Alves (orgs.) São Paulo, Perspectiva, 2006.

NAUGRETTE, Catherine. L'esthétique théâtrale. Paris, Nathan, 2000.

NEEDELL, Jeffrey D. Belle époque tropical. São Paulo, Companhia das Letras, 1993.

NIETZCHE, Frederico. A Origem da Tragédia. Lisboa, Guimarães Editores, 1985. . Obras Incompletas. Editora Nova Cultural, São Paulo, 1999.

NUNES, Mário. 40 anos de teatro. 3 volumes, Rio de Janeiro, SNT, s.d.

O homem do povo. Coleção completa e fac-similar dos jornais escritos por Oswald de Andrade e Patrícia Galvão (Pagu). São Paulo, Imprensa Oficial do Estado, Arquivo do Estado, 1984. 
OLIVEIRA, Carlos Daudt de (trad.). A epopéia de Gilgamesh (Anônimo). São Paulo, Martins Fontes, 2001.

PAVIS, Patrice. A análise dos espetáculos. São Paulo, Perspectiva, 2003. . Dicionário de teatro. São Paulo, Perspectiva, 2001. . Voix et images de la scène. Presses Universitaires de Lille, 1985. .”Production et réception au théâtre: la concretisation du texte dramatique et spetaculaire”. Revue des Sciences Humanes, nº 189, 1983.

PAZ, Octavio. Os filhos do barro. Rio de Janeiro, Nova Fronteira, 1984.

PEREIRA, Victor Hugo Adler. A musa carrancuda: teatro e poder no Estado Novo. Rio de Janeiro, Editora Fundação Getúlio Vargas, 1998.

PISCATOR, Erwin. Teatro político. Rio de Janeiro, Editora Civilização Brasileira, 1968.

PRADO, Décio de Almeida. O teatro moderno brasileiro. São Paulo, Perspectiva, 2003. Teatro em progresso. São Paulo, Perspectiva, 2002.

RABETTI, Beti. Contribuição para o estudo do moderno teatro brasileiro: a presença italiana. Tese de Doutorado. Faculdade Letras, Filosofia e Ciências Humanas da Universidade de São Paulo, 1989. . Teatro e comicidades 2: modos de produção do teatro ligeiro carioca. Rio de Janeiro, 7Letras, 2007.

REVISTA DA ACADEMIA BRASILEIRA DE LETRAS, volume XXIV, Edição do Anuário do Brasil, Rio de Janeiro, s/d.

ROSENFELD, Anatol. Prismas do Teatro. São Paulo : Perspectiva / EDUSP / Editora da Unicamp, 1993.

Teatro Épico. São Paulo, Perspectiva, 1985. 
. Teatro Moderno. São Paulo : Perspectiva, 1977.

ROUBINE, Jean-Jacques. Introdução às grandes teorias do teatro. Rio de Janeiro, Jorge Zahar Ed., 2003.

RYNGAERT, Jean-Pierre. Introdução à análise do teatro. São Paulo, Martins Fontes, 1996.

SALIBA, Elias Thomé. A dimensão cômica da vida privada na República. In: SEVCENKO

Nicolau (org.). História da vida privada no Brasil, vol. 3. São Paulo, Companhia das Letras, 1998.

SANTOS, Sérgio Ricardo de Carvalho. O drama impossível: teatro modernista de Alcântara Machado, Oswald de Andrade e Mário de Andrade. Tese de doutorado, Faculdade de Letras, Filosofia e Ciências Humanas da Universidade de São Paulo, 2002.

SARRAZAC, Jean Pierre. O futuro do drama: escritas dramáticas contemporâneas. Porto, Campos das Letras, 2002.

SEVCENKO, Nicolau. Literatura como missão: tensões sociais e criação cultural na Primeira República. São Paulo, Companhia das Letras, 2003.

SIGNER, Rina. Ingredientes para uma nouvelle cuisine: o rei da vela ao molho de Ubu Rei. Tese de doutoramento apresentada ao Departamento de Letras Modernas da Faculdade de Letras e Ciências Humanas da Universidade de São Paulo, 2000.

SOUZA, Cláudio de. Flores de sombra. Rio de Janeiro, Lith. Typ. Fluminense, 1922.

SUSSEKIND, Flora. Cinematógrafo de letras. São Paulo, Companhia das Letras, 2006. . Papéis colados. Rio de Janeiro, Editora UFRJ, 1993.

SZONDI, Peter. Teoria do drama burguês. São Paulo, Cosac e Naify Edições, 2004. . Teoria do drama moderno (1880-1950). São Paulo, Cosac e Naify Edições, 2001. 
TELES, Gilberto Mendonça. Vanguarda européia e modernismo brasileiro: apresentação e crítica dos principais poemas, manifestos, prefácios e conferências vanguardistas, de 1857 a 1972. Petrópolis, Editora Vozes, 2005.

TOJEIRO, Gastão. Onde canta o sabiá. Rio de Janeiro, SNT/MEC, 1973.

TOLEDO, J. Flávio de Carvalho: o comedor de emoções. São Paulo, Brasiliense, Campinas, Editora da Unicamp, 1994.

TOURRAINE, Alain. Um Novo Paradigma. Petrópolis, Vozes, 2006.

TRAGTEMBERG, Lívio. Artigos musicais. São Paulo, Perspectiva, 1991.

UBERSFELD, Anne. L’école du spectateur. Paris, Éditions Sociales, 1991.

VIANNA, Renato. A última encarnação de Fausto. Arquivo SBAT, s/d.

ZILBERMAN, Regina. Estética da recepção e história da literatura. São Paulo, Ática, 1989.

ZOLA, Émile. O romance experimental e o naturalismo no teatro. São Paulo, Perspectiva, 1982.

\section{Periódicos consultados. $^{1}$}

Jornal do Commércio.

11/07/1903.

André Antoine.

“Conferência Antoine”.

O Estado de São Paulo.

23/12/1916.

Não assinada.

\footnotetext{
${ }^{1}$ Acervo da Fundação Biblioteca Nacional - Brasil.
} 
“Flores de Sombra”.

Jornal do Commércio.

31/07/1920.

Oscar Guanabarino.

“Luciano, o encantador”.

O Jornal.

19/12/1922.

Otávio Quintiliano.

"Batalha da Quimera”.

Jornal do Commércio.

17/12/1922.

Oscar Guanabarino.

"Batalha da Quimera”.

O Paiz.

17/12/1922.

Crítica não assinada.

"Batalha da Quimera”.

A Noite

18/12/1922.

Crítica não assinada.

“A última encarnação de Fausto”.

Diário Nacional.

12/04/1928.

António Alcântara Machado.

"Ibsen”. 
Jornal do Commércio.

10/12/1924.

António Alcântara Machado.

"Vespeiro".

Jornal do Commércio.

26/02/1925.

António Alcântara Machado.

"Desgraçado teatro".

Jornal do Commércio

15/03/1924.

António Alcântara Machado.

“Dick”.

Jornal do Commércio.

01/02/1923.

António Alcântara Machado.

“A Juriti”.

Homem do Povo.

São Paulo, 31/03/1931.

Flávio de Carvalho.

“Teatro antigo e moderno".

O Dia

São Paulo, 17/11/1933.

“O teatro da experiência às voltas com a polícia!”

A Noite. 
Rio de Janeiro, 21/11/1933.

Flávio de Carvalho.

“O bailado do deus morto".

Correio da manhã.

São Paulo, 06/12/1933.

Flávio de Carvalho.

“O teatro da experiência”.

Correio da manhã.

Rio de Janeiro, 20/02/1946.

Oswald de Andrade.

"Casa de boneca”. 